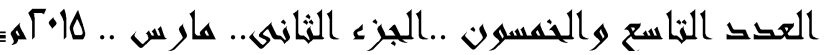

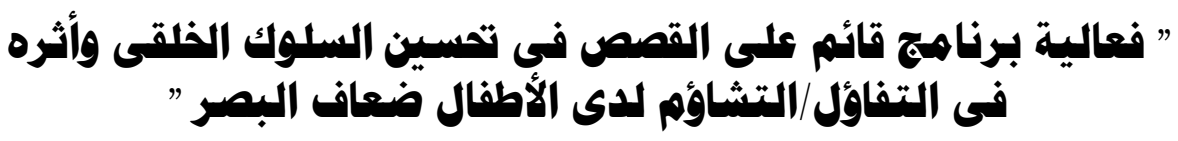

د/ محمل النوبى محمل على

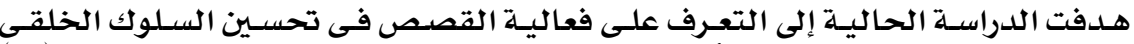

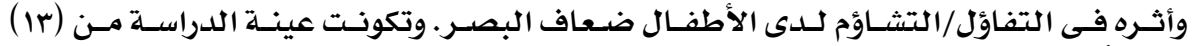

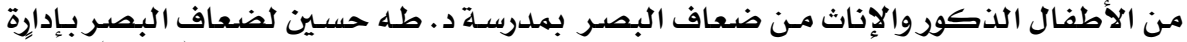

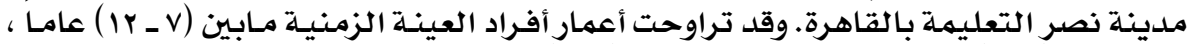

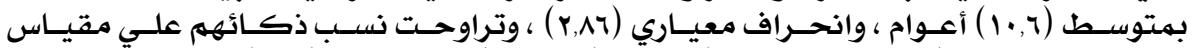

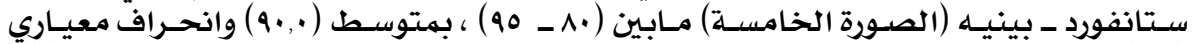

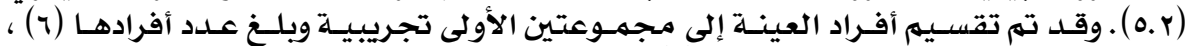

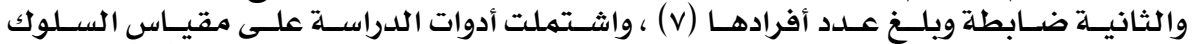

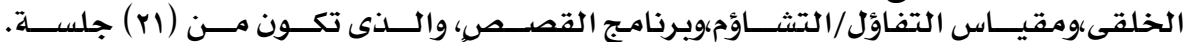

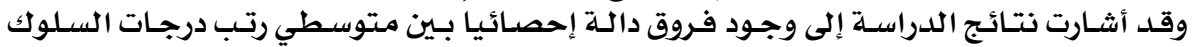

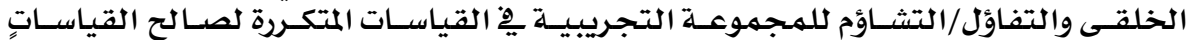

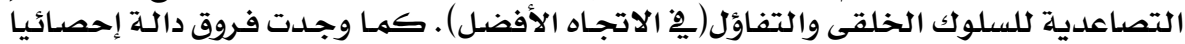

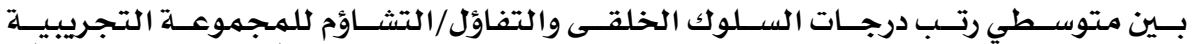

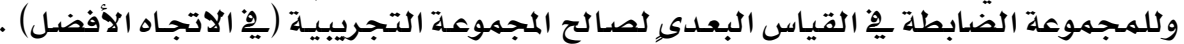

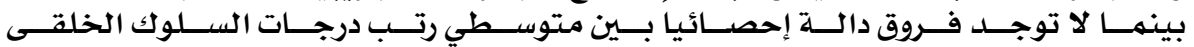

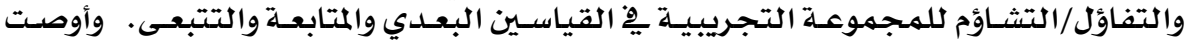

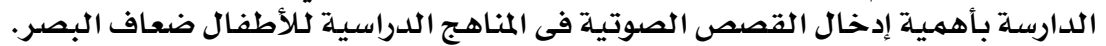

الكلمات المفتاحية : القصص ـ السلوك الخلقى ـ التفاؤل/التشاؤم ـ الأطفال ضعاف البصر. Effectiveness of A Stories Based Program in Improving the Moral Behavior and its Impact on Optimism /Pessimism for Visually Impaired Children

Abstract :

The study aimed to identify the effectiveness of a program based on the stories in improving moral behavior and its impact on Optimism and pessimism for children visual impaired. The participants consisted of (13)of the boys and girls with visual impaired in D. Taha Hussein School for the visual impaired educational instruction Nasr City, Cairo. The sample has ranged from the ages of (7-12) years, with an average (10.6) years, and a standard deviation (2.86). The proportion of intelligence ranged between (80-95), average (90.0) and standard deviation (5.2).The participants were divided respondents into two groups: the first (6) children, and the second had (7)children.The study included tools : moral behavior test, and the optimism / pessimism test, and the program of stories, which consisted of (21) session. The results of the study indicated that there are significant differences among the middle ranks degrees of moral behavior and optimism I pessimism experimental group in repeated measurements in favor of progressive measurements of the moral behavior and optimism / pessimism

\title{
$r \cdot V$
}


العكد التزاسع والخمسول ..الجزء الثمانىى.. هارس ..

(at best) direction. are As there are significant differences among the middle ranks degrees of moral behavior and optimism / pessimism experimental group in the two measurements pre and post in favor of the dimensional measurement (in the best direction. while significant differences no statistically among the middle ranks degrees moral behavior and optimism / pessimism of the group behavior control in the two measurements posttest and follow-up and iterative. As recommended by the study of the importance of the introduction of audio stories in the curriculum for children impaired sight..

Keywords: Stories - Moral Behavior - Optimism / Pessimism - Visually Impaired Children.

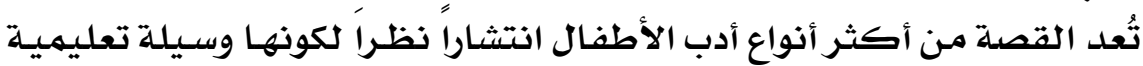

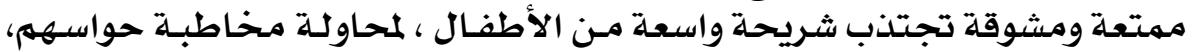

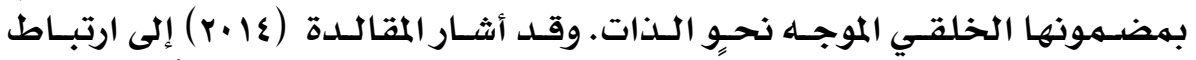

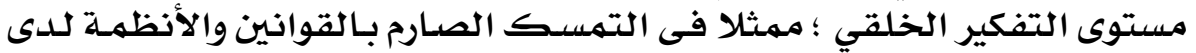

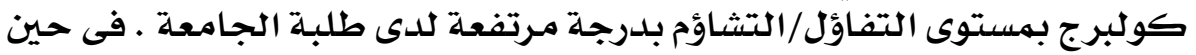

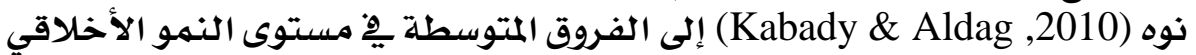

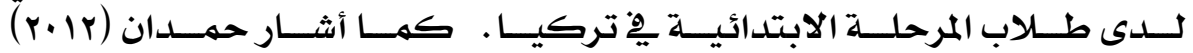

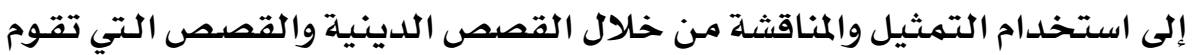

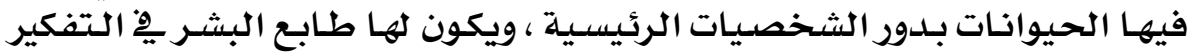

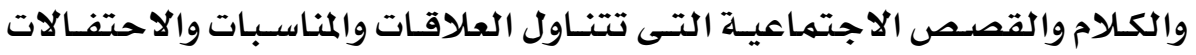

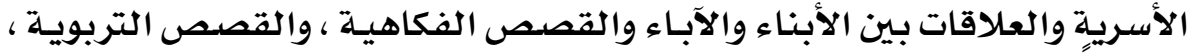

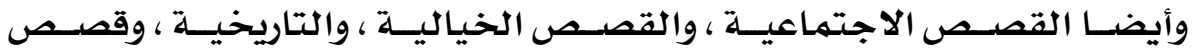

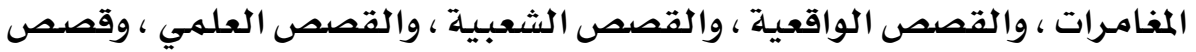

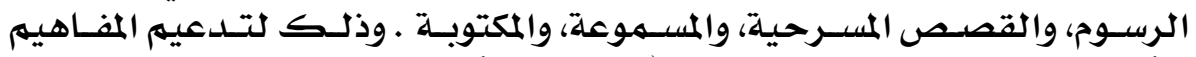

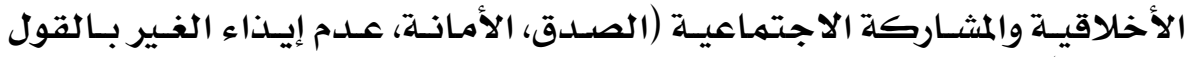

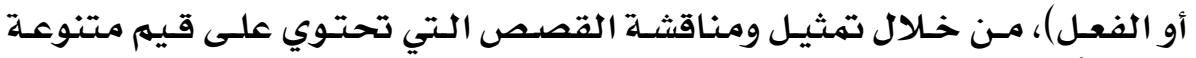

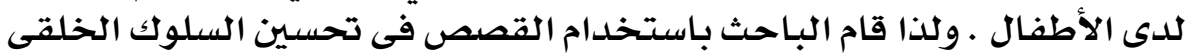

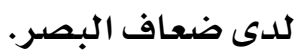

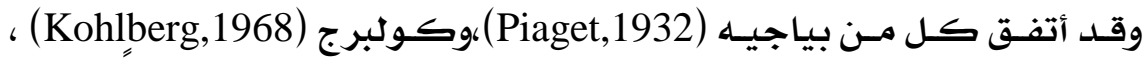

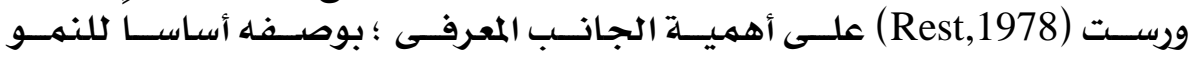

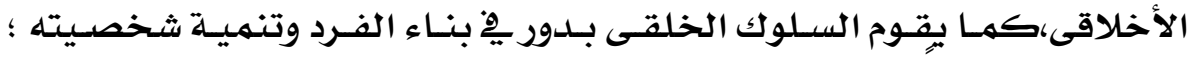

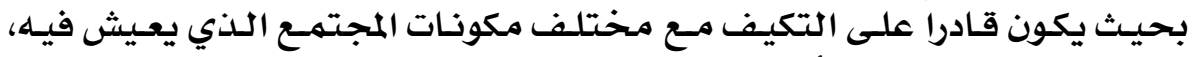

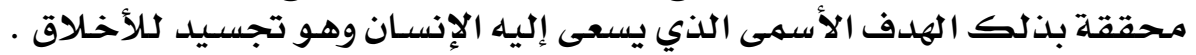

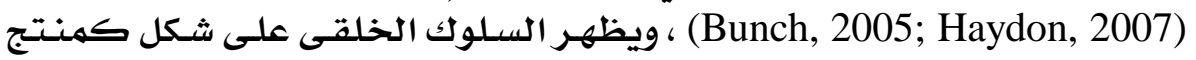

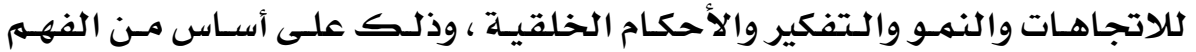

\section{$Y \cdot \Lambda$}




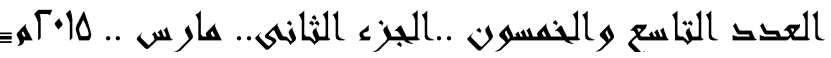

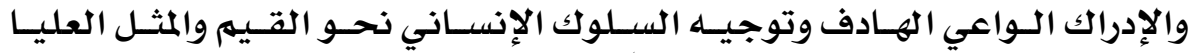

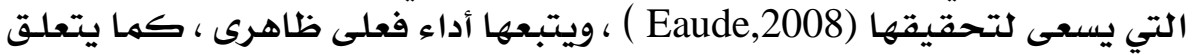

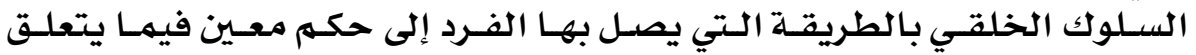

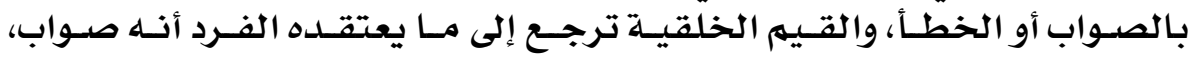

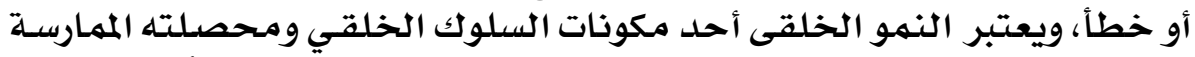

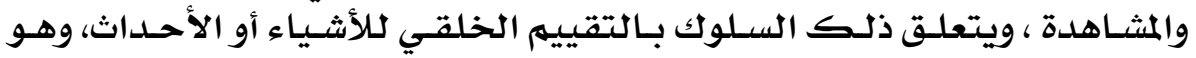

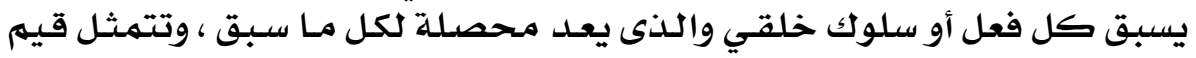

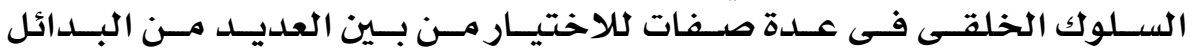

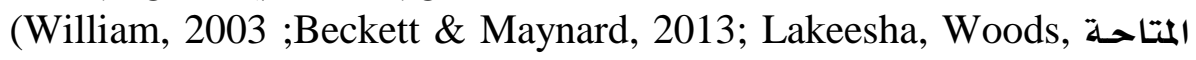
Robert \& Jagers, 2003).

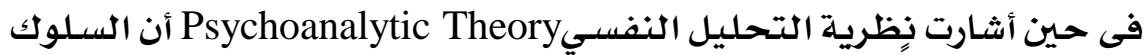

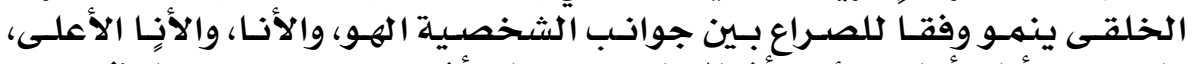

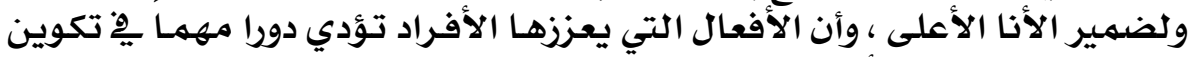

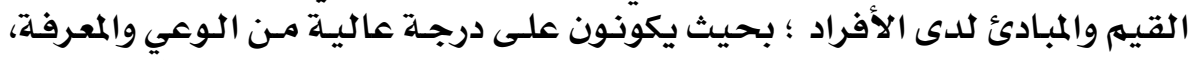

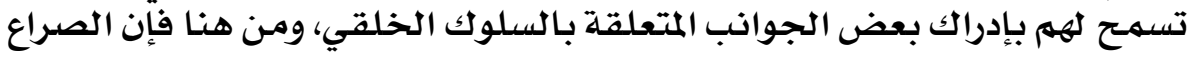

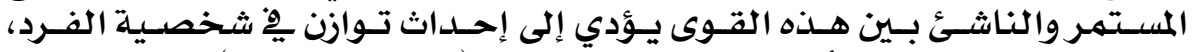

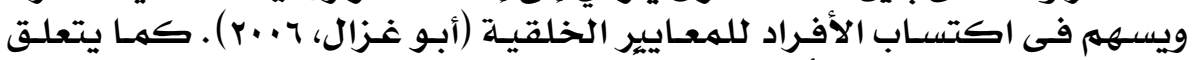

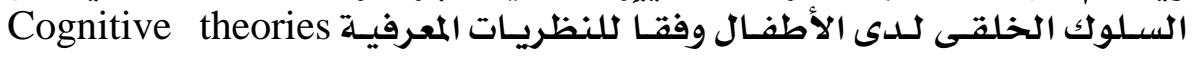

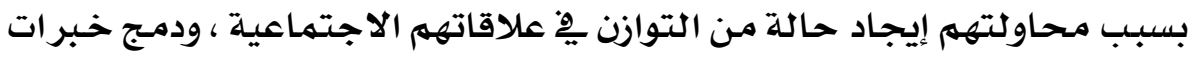

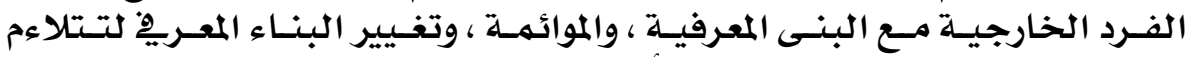

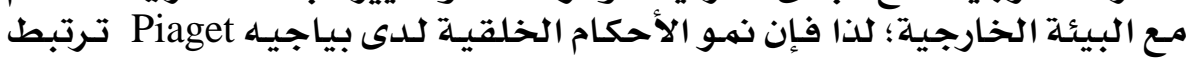

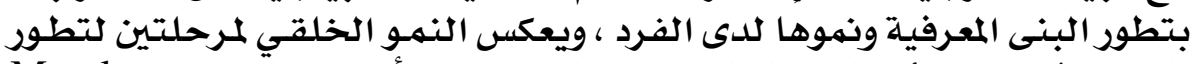

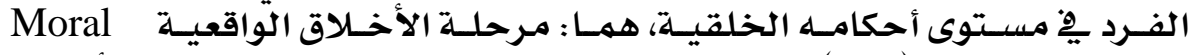

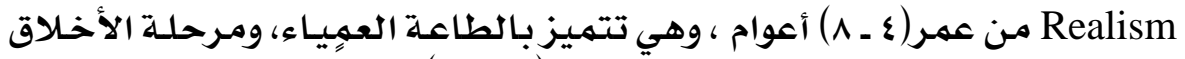

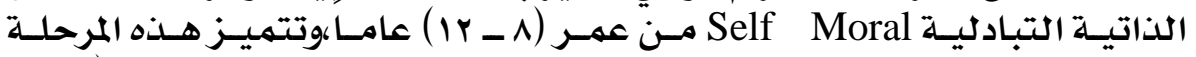

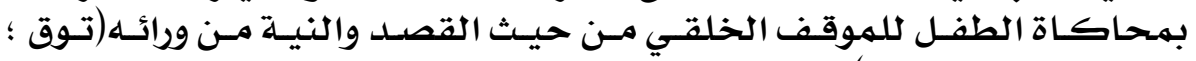
عدس؛ وقطامي، r... r. (r).

; Walkowitz;Wichardt;Lindeman\&Verkasalo Lönnqvist كما أثـار،

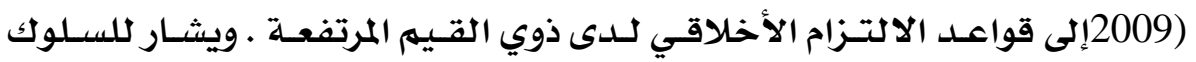

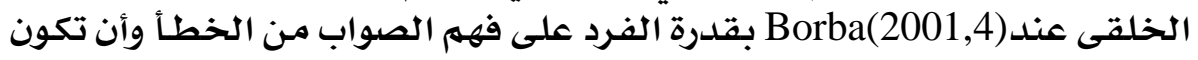

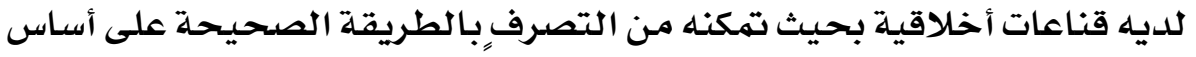

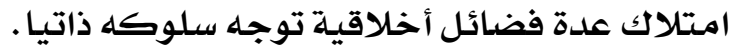

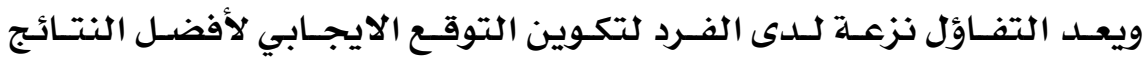

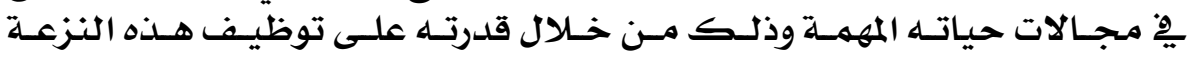

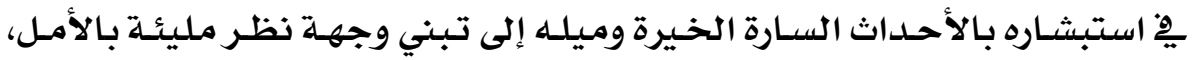

\section{r. 9}


العكد التزاسع والخمسول ..الجزء الثمانىى.. هارس ..

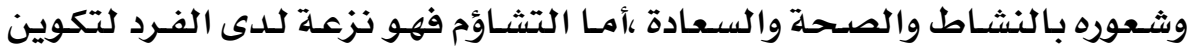

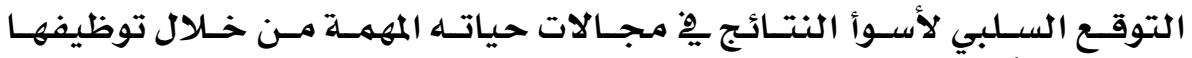

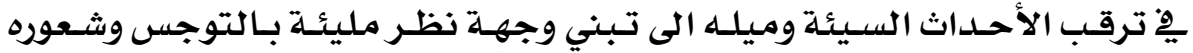

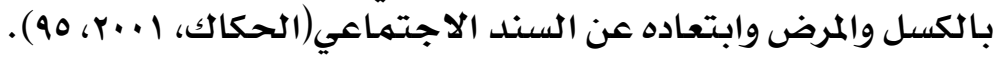

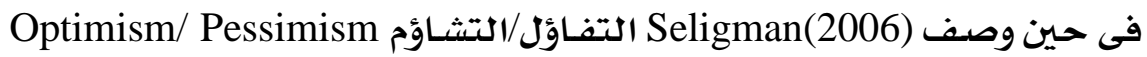

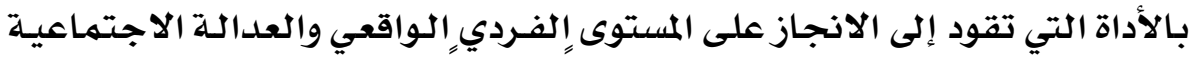

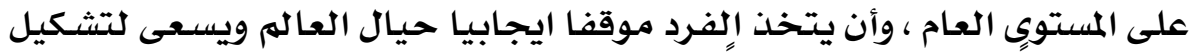

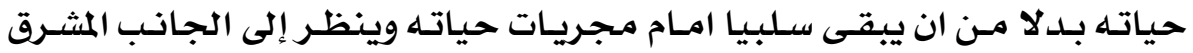

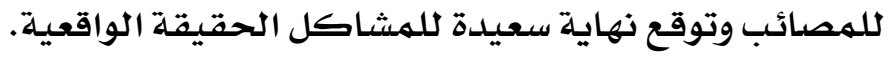

Fernández-González;González-Hernández\&Trianes-Torre كما أثـار

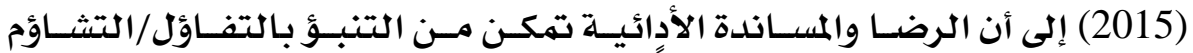

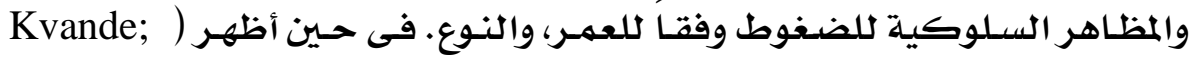
والن Klöckner; Moksnes \& Espnes (2015)

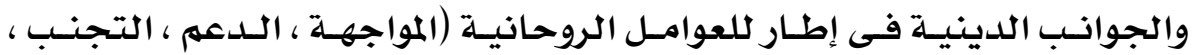

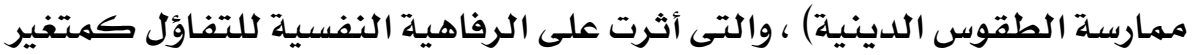

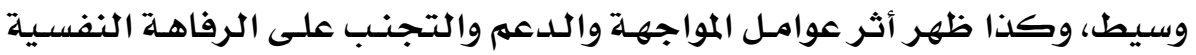

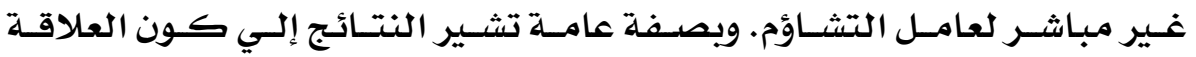

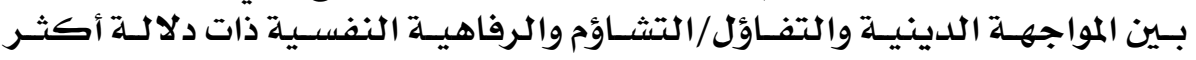

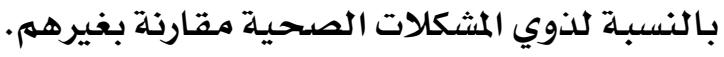

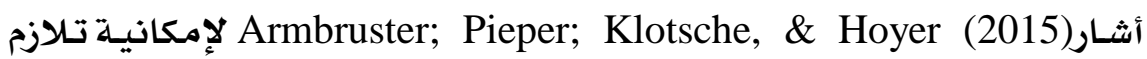

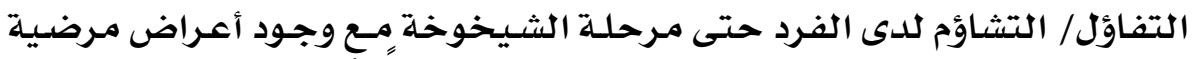

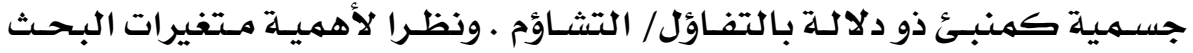

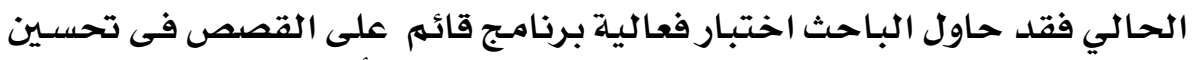

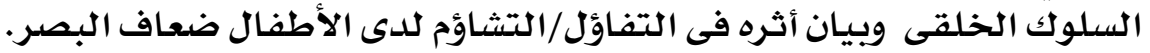

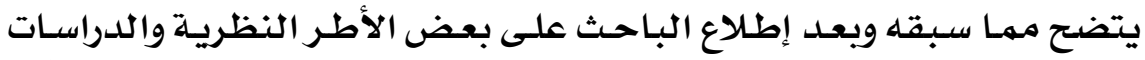

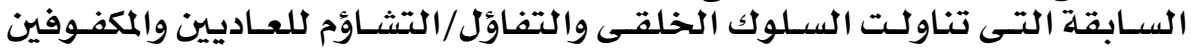

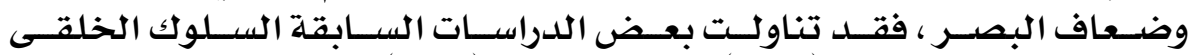

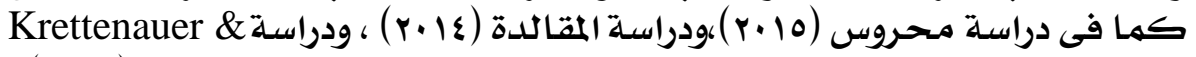

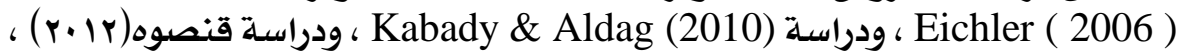

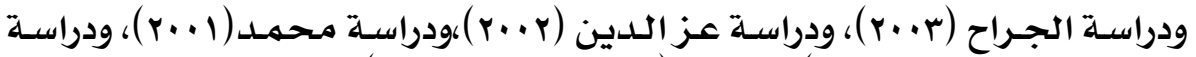

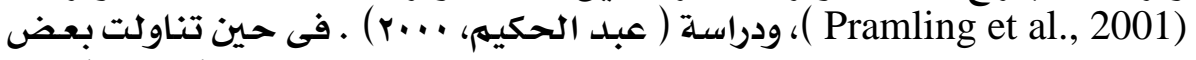

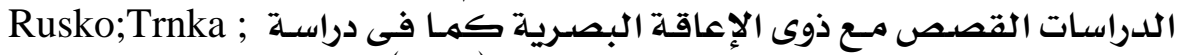
Darjaa \& Ritomský(2014)

\section{Y 1 .}




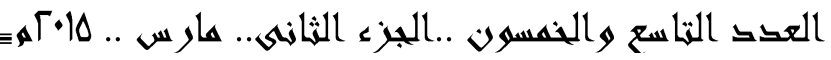

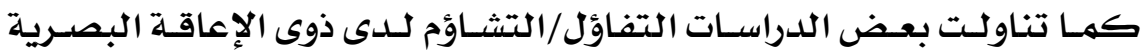

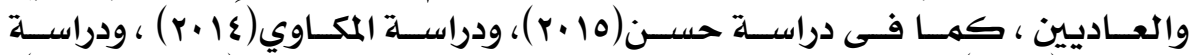

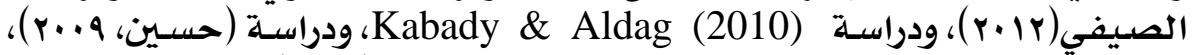

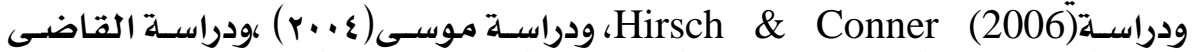

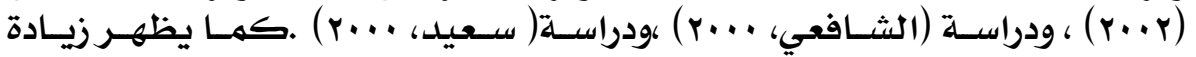

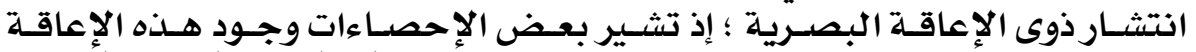

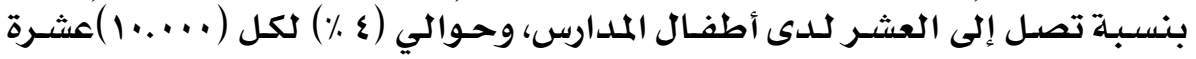

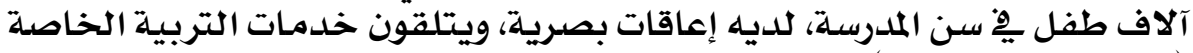

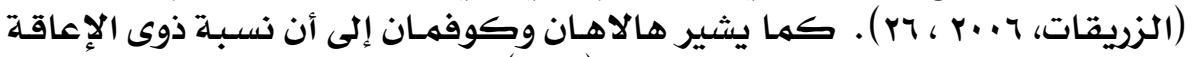

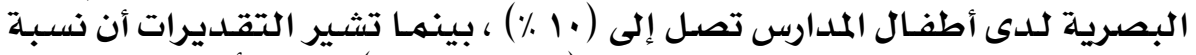

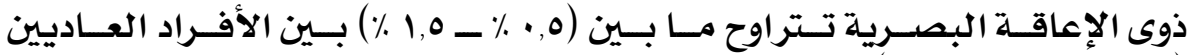

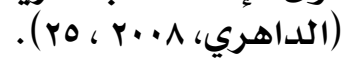

وتتحدد مشكلة البحث الحالي يِّ التساؤلات التالية :

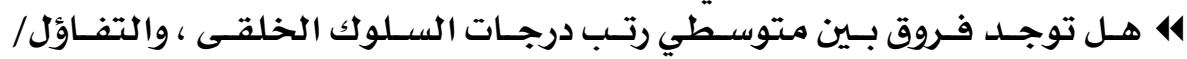

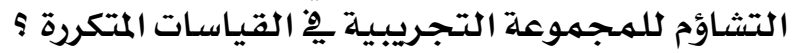

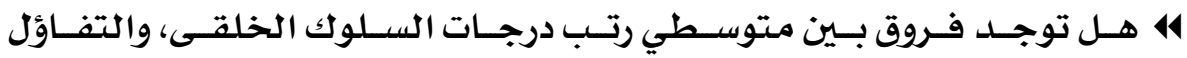

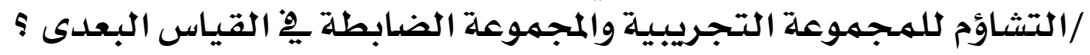

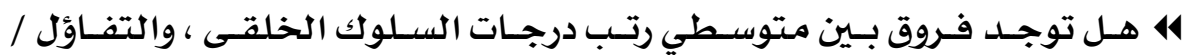

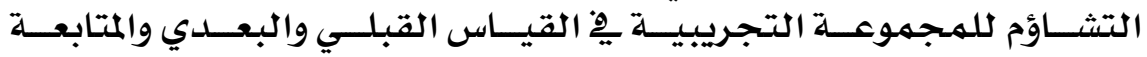

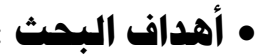

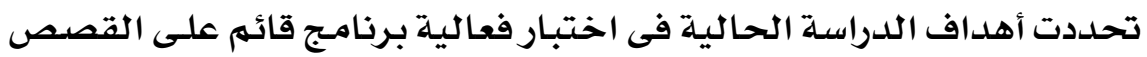

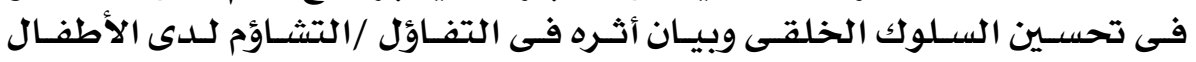

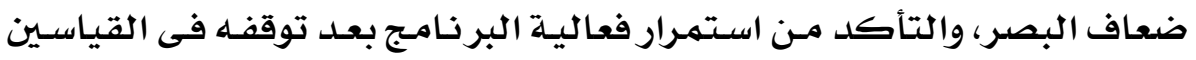

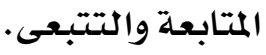

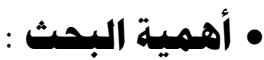

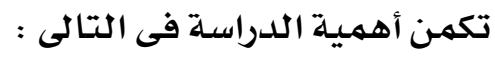

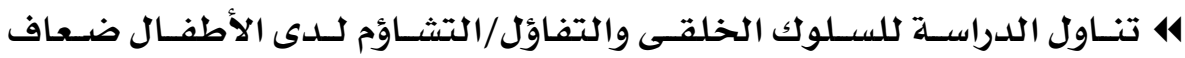

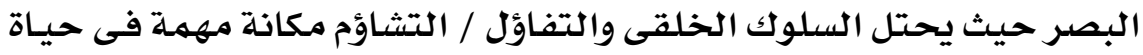

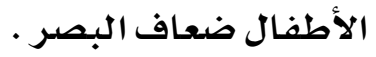

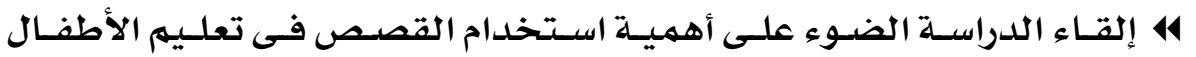

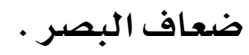

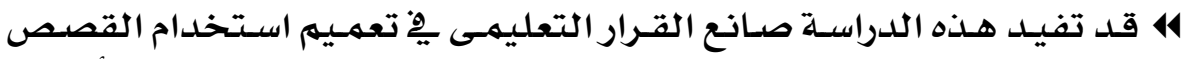

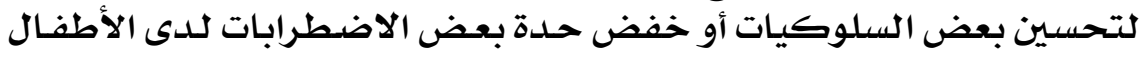

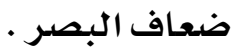

\section{Y}


العكد التزاسع والخمسول ..الجزء الثمانىى.. هارس ..

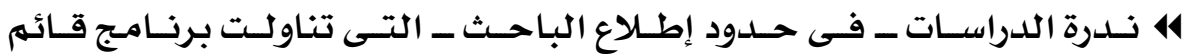

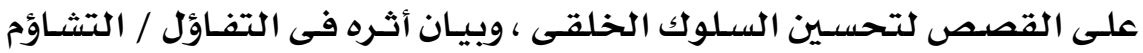

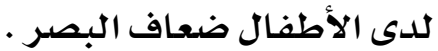

• Visually Impaired الأطفال ضعاف البصر :

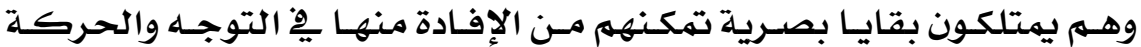

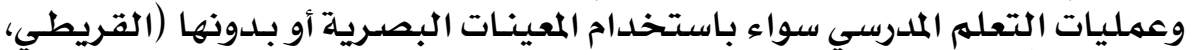

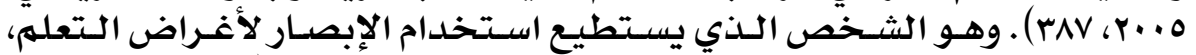

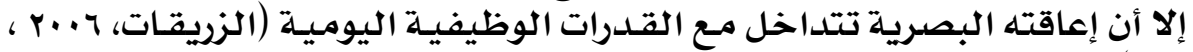

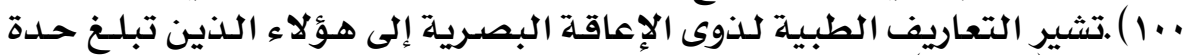

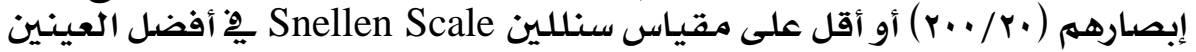

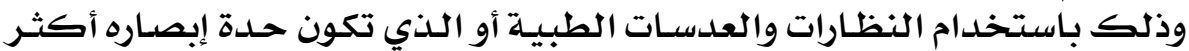

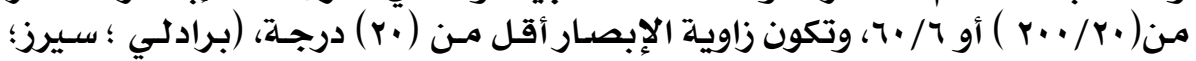

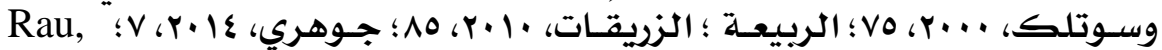

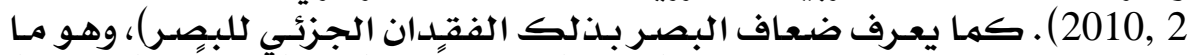

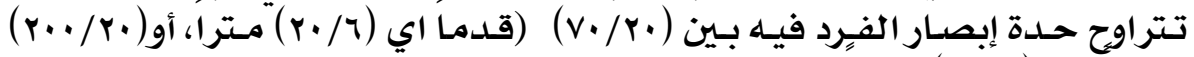

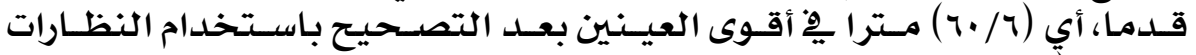

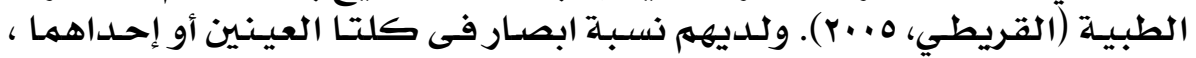

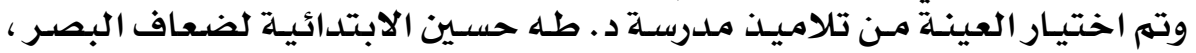

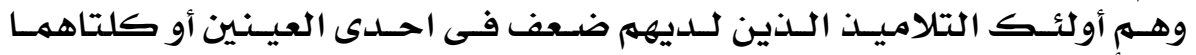

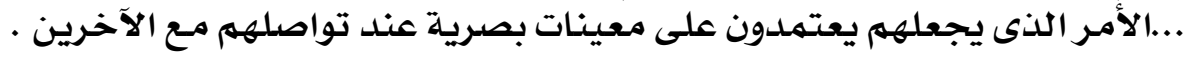

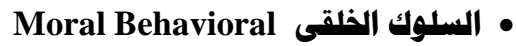

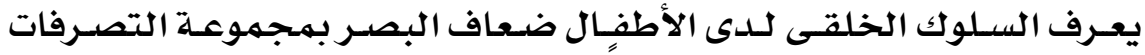

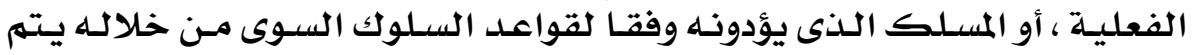

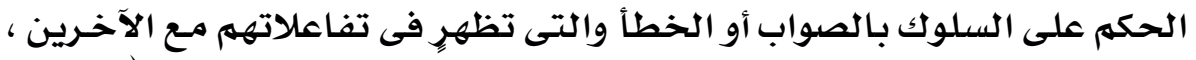

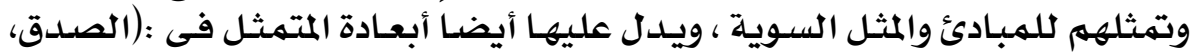

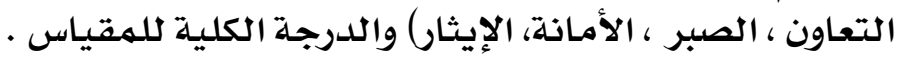

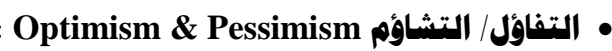

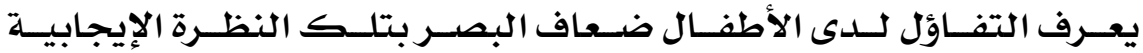

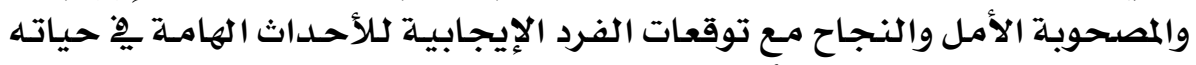

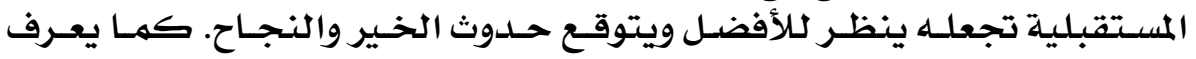

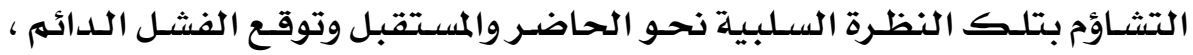

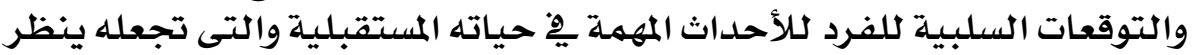

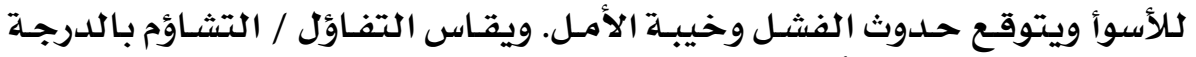

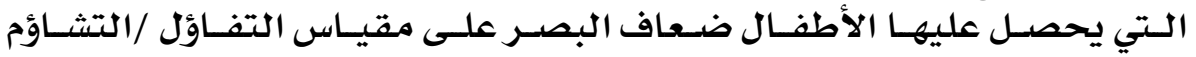

\section{YIY}


العكد التزاسع والخمسول ..الجزء الثخانىى.. هارس ..

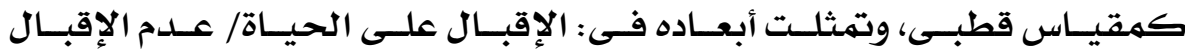

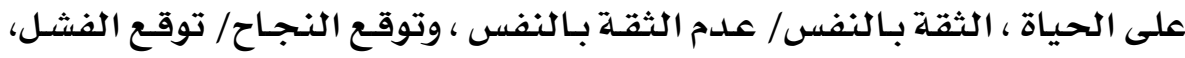

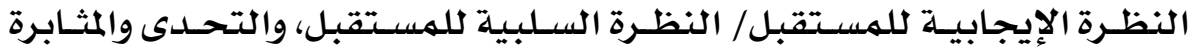

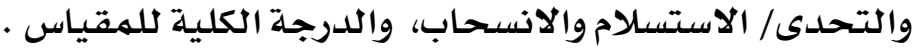

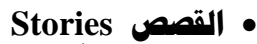

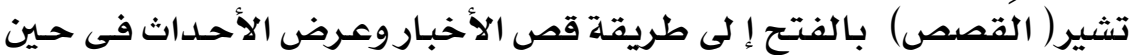

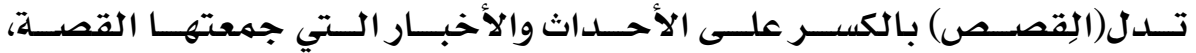

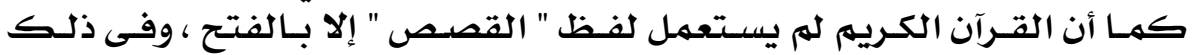

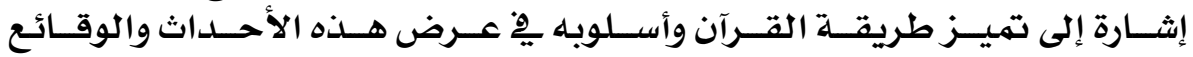

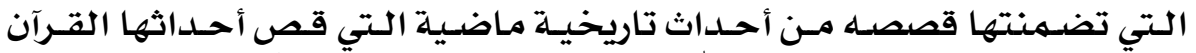

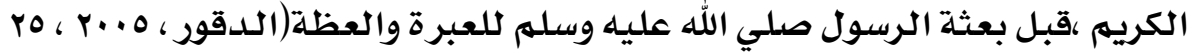

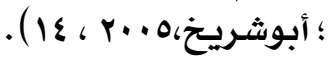

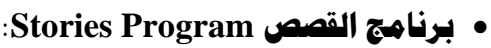

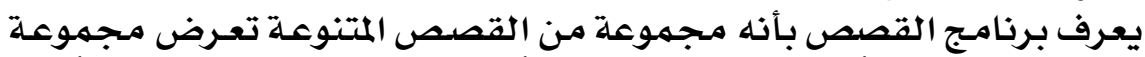

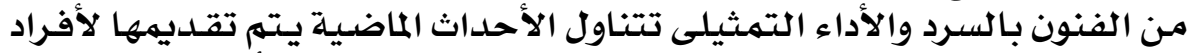

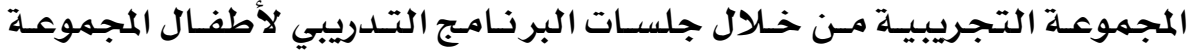

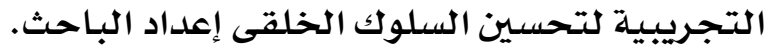

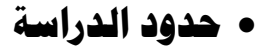

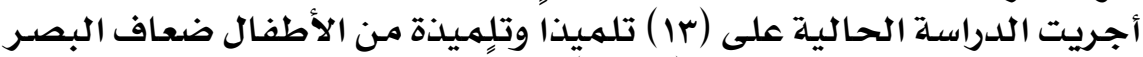

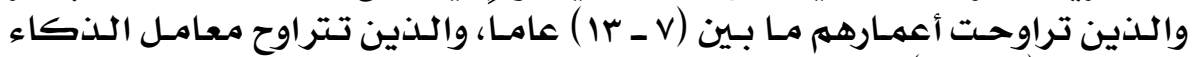

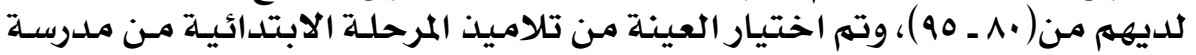

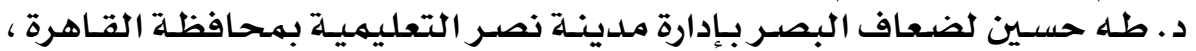

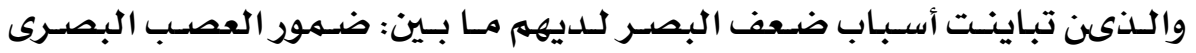

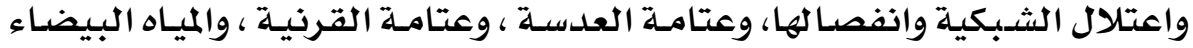

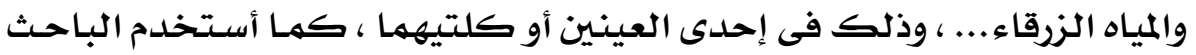

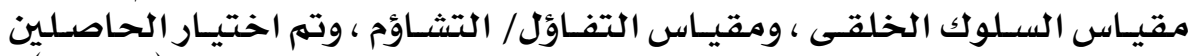

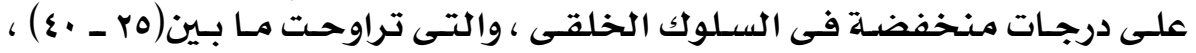

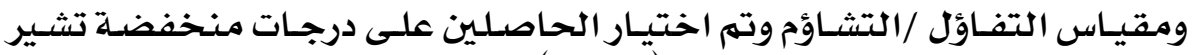

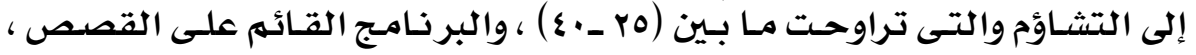

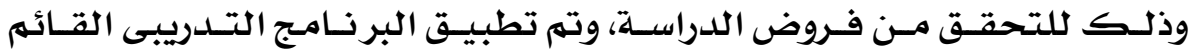

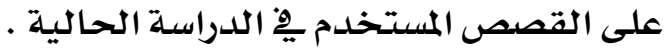

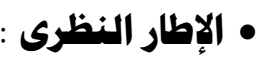

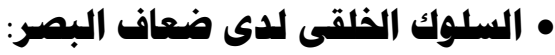

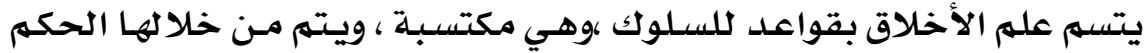

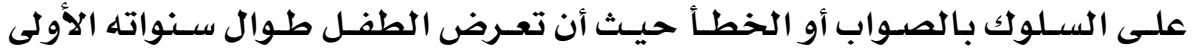

\section{YIY}


العكد التزاسع والخمسول ..الجزء الثمانىى.. هارس ..

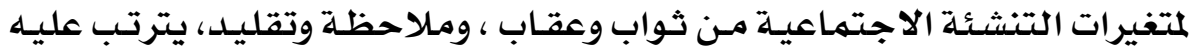

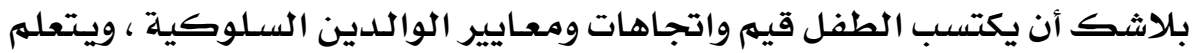

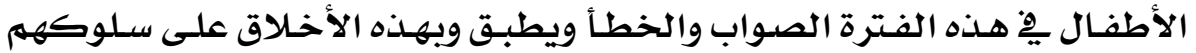

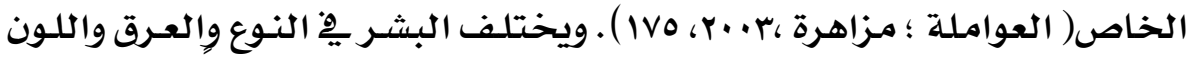

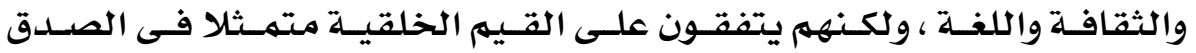

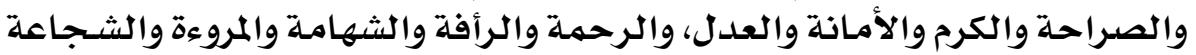

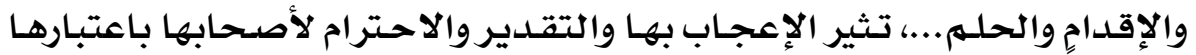

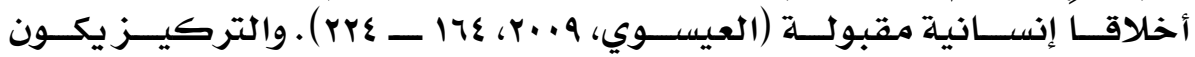

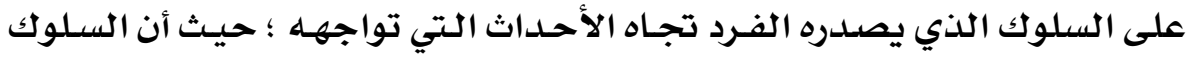

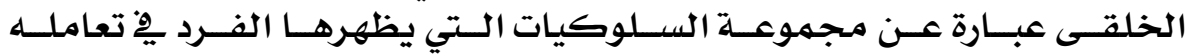

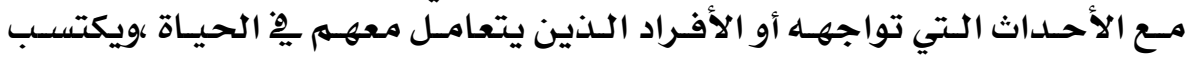

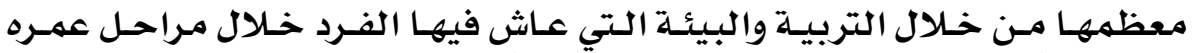

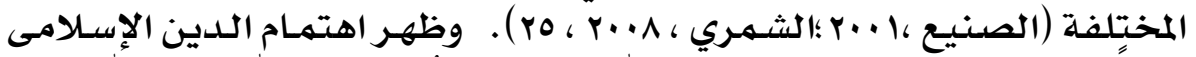

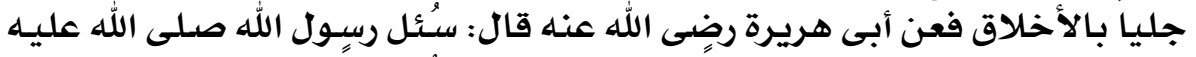

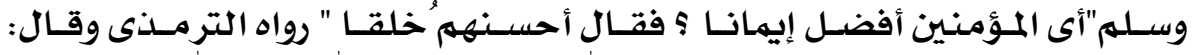

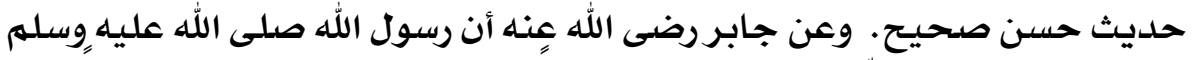

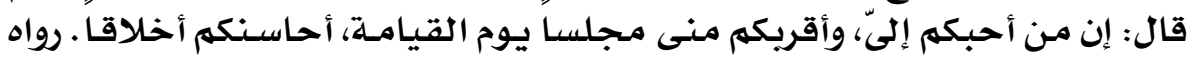

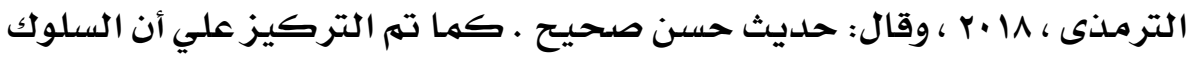

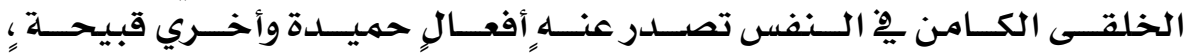

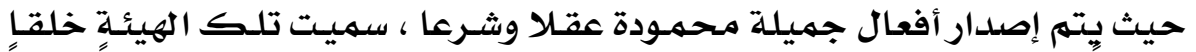

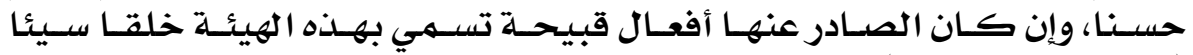

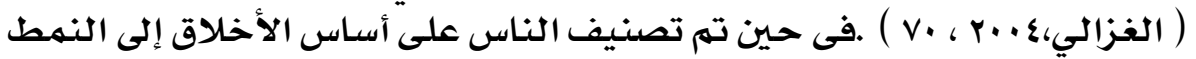

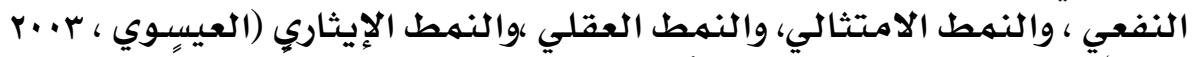

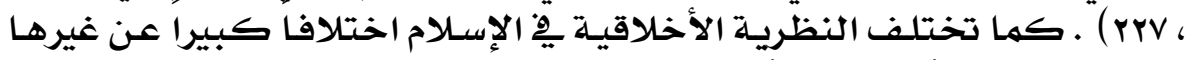

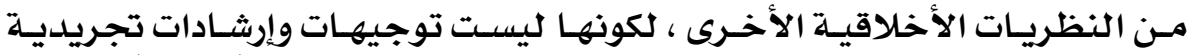

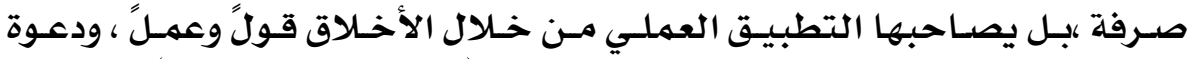

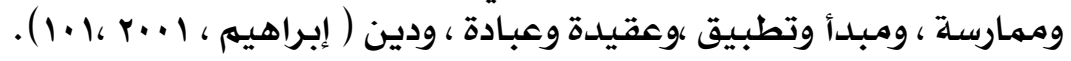

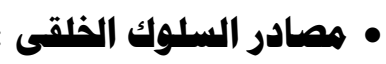

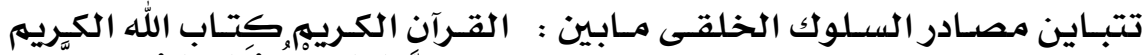

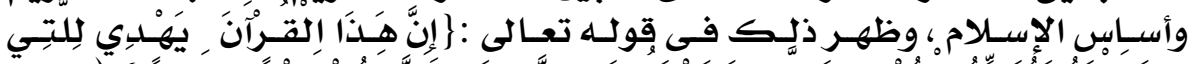

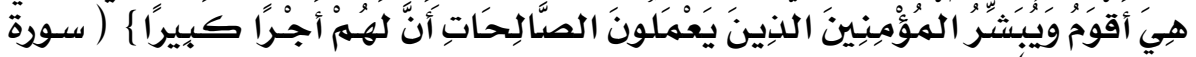

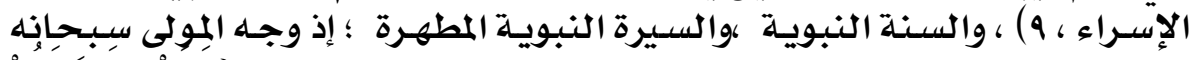

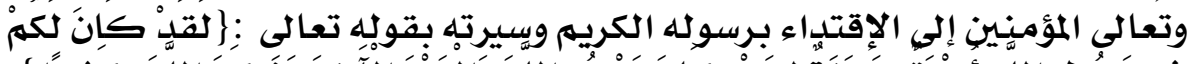

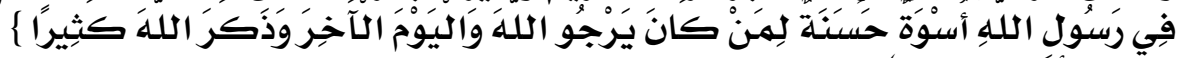

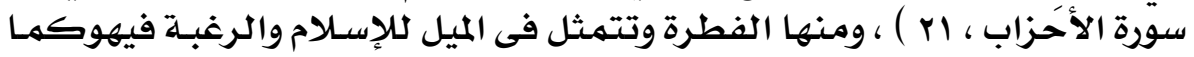

\section{Y \&}




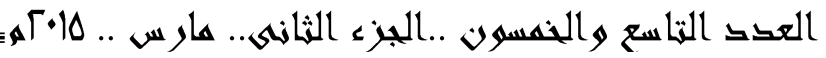

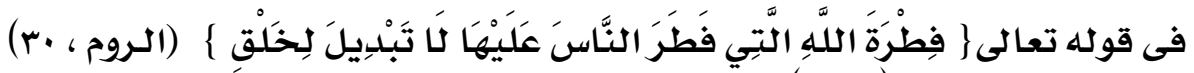

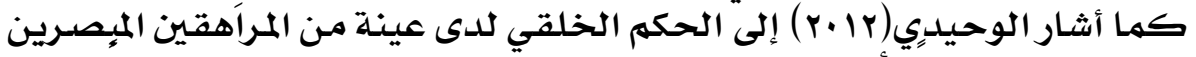

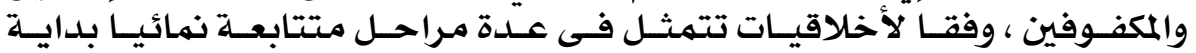

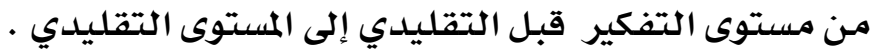

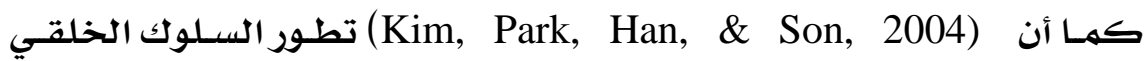

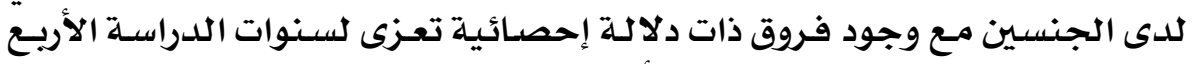

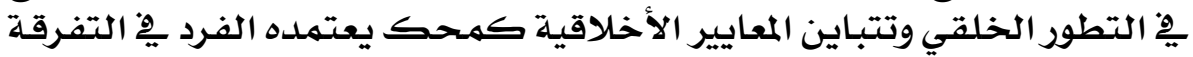

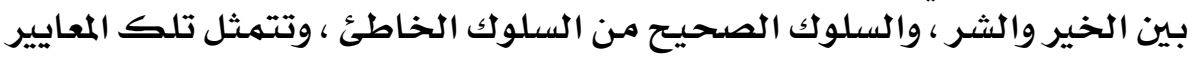

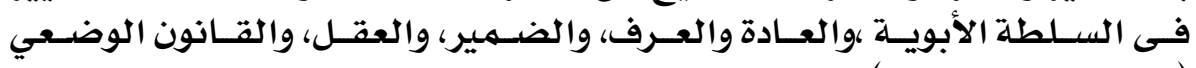

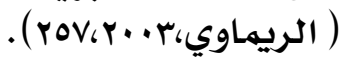

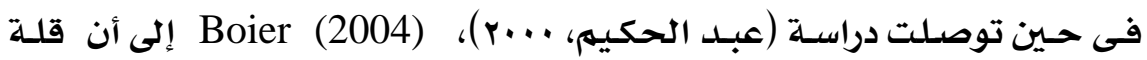

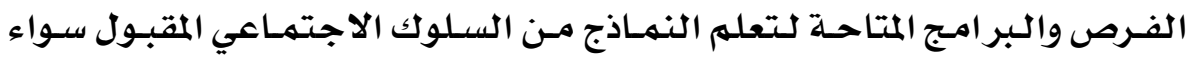

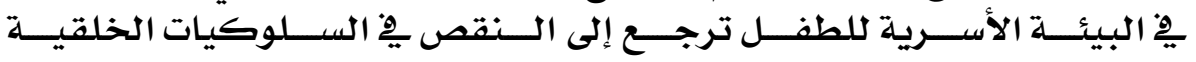

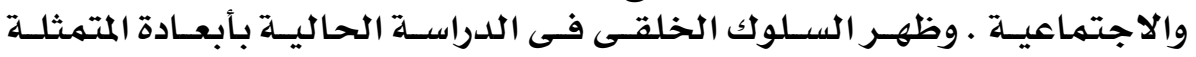

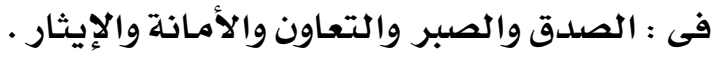

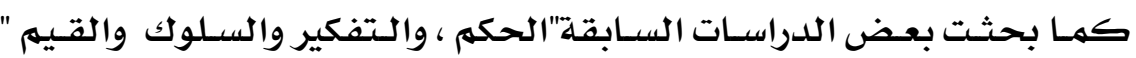

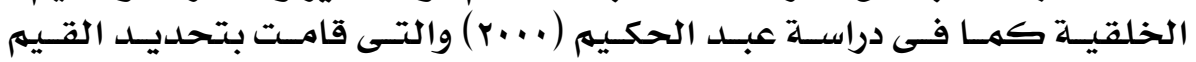

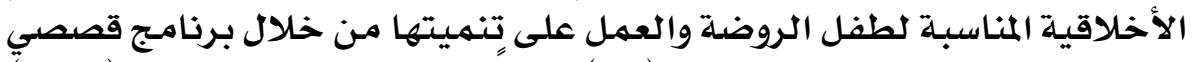

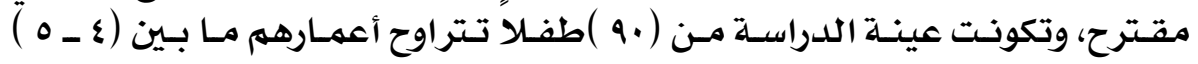

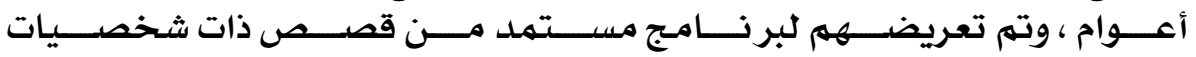

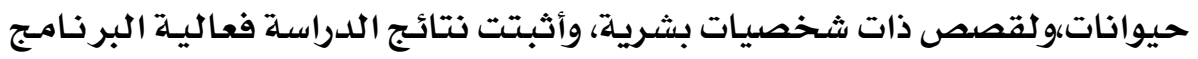

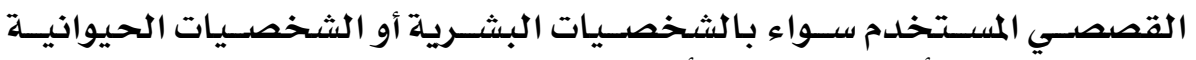

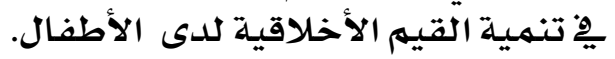

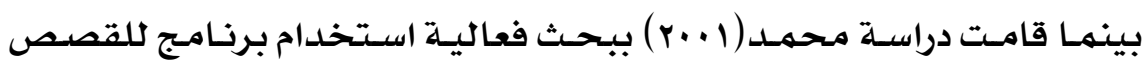

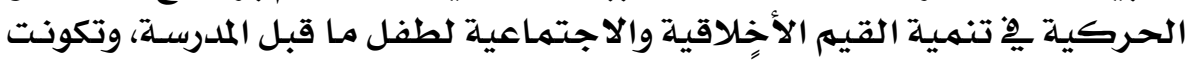

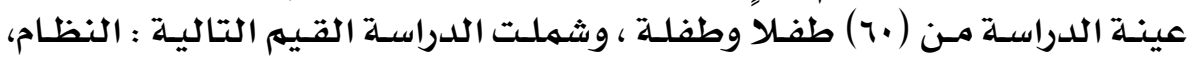

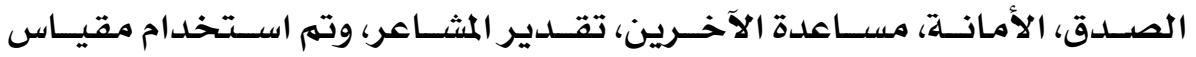

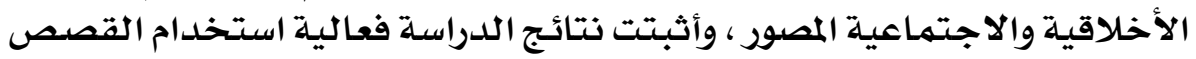

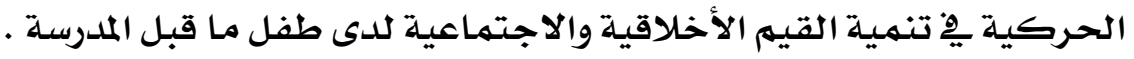

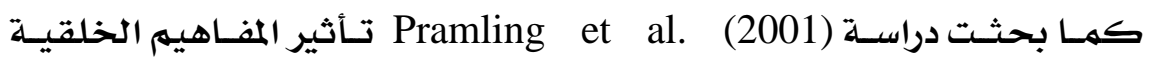

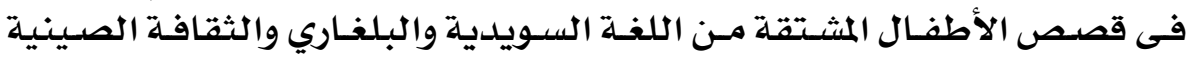

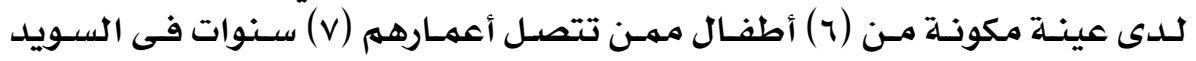

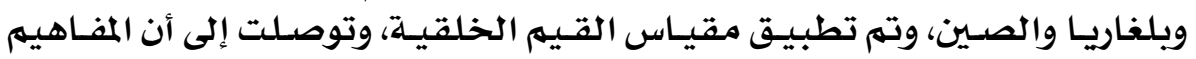

\section{Y 10}




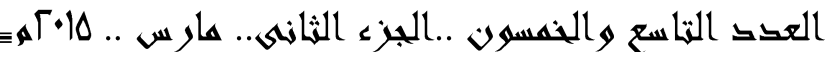

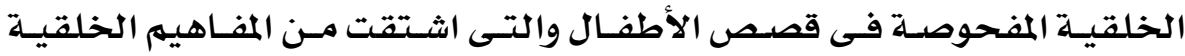
من وجهة النظر النفسية في إطار السهمات الثقافية والقيهم الخلقية الفية للأطفال .

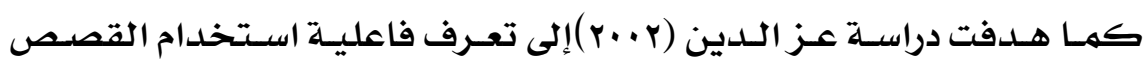

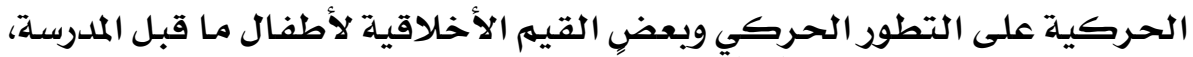

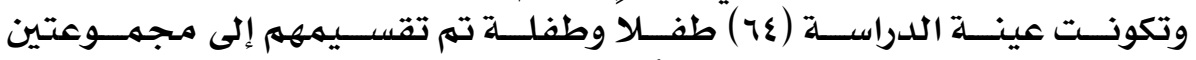

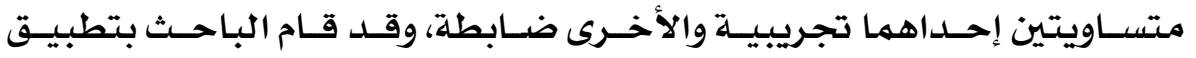

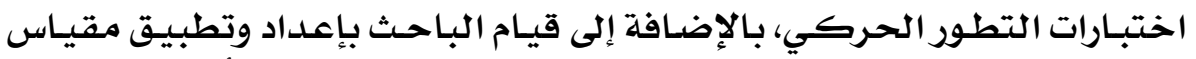

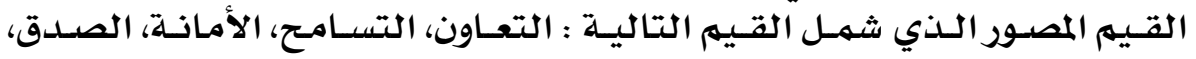

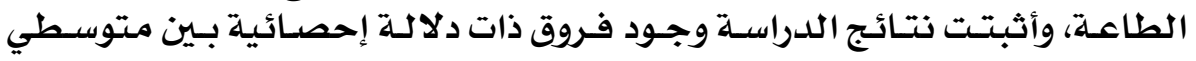

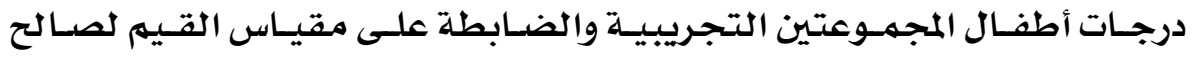
أطفال المجموعة التجريبية.

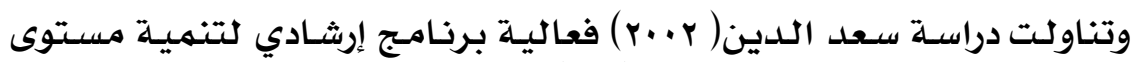

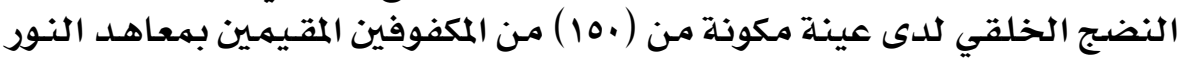

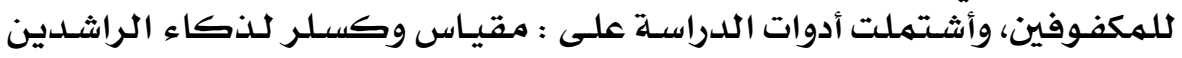

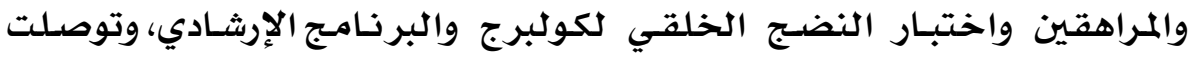

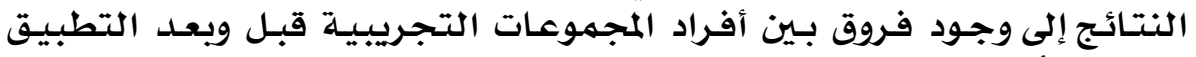

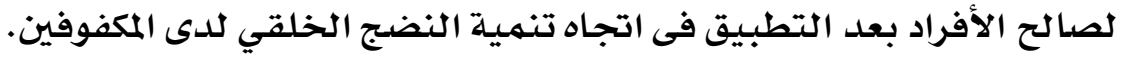

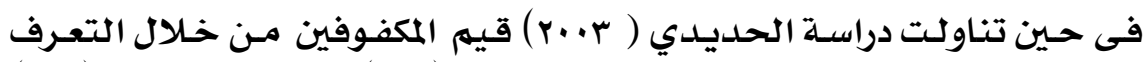

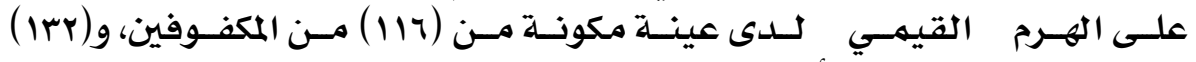

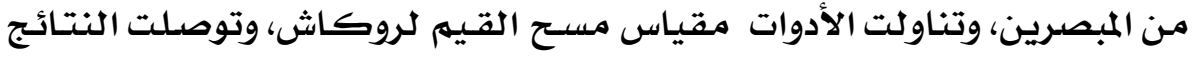

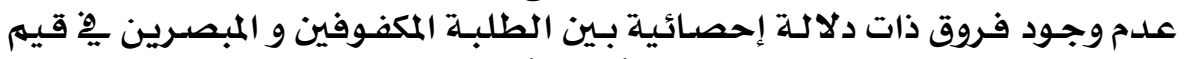

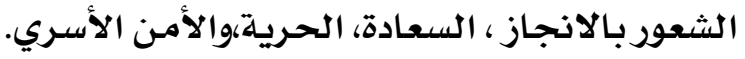

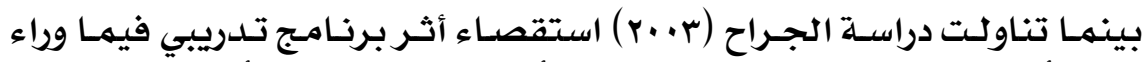

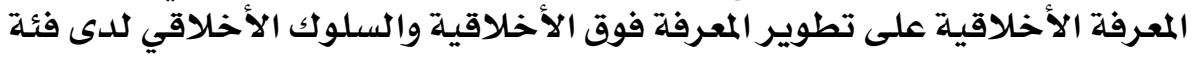

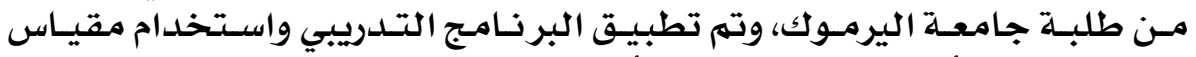

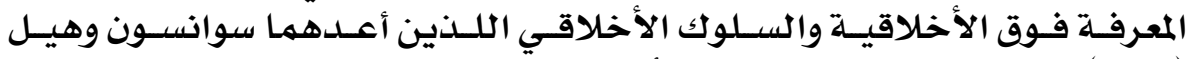

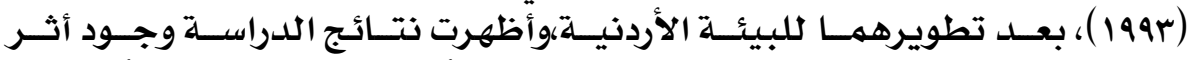

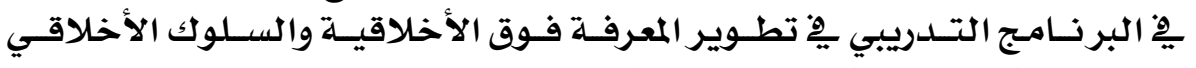

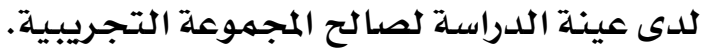

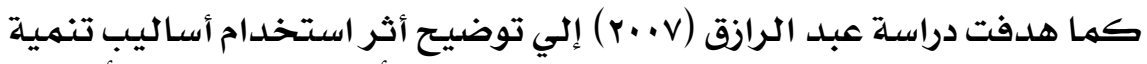

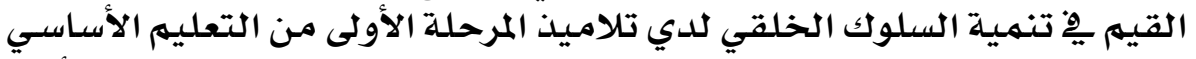

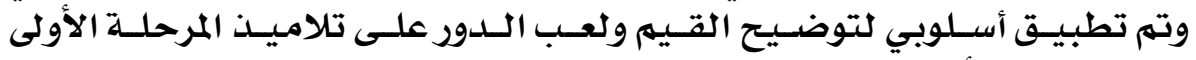

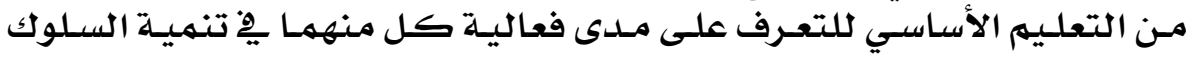

\section{Y 17}


العكد التزاسع والخمسول ..الجزء الثخانىى.. هارس ..

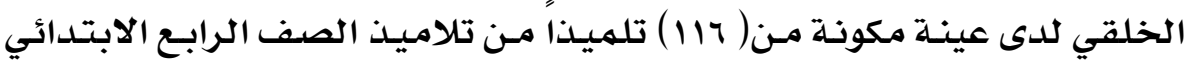

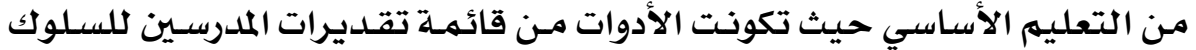

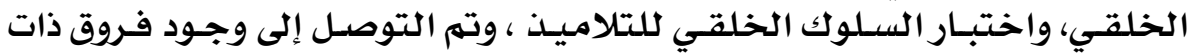

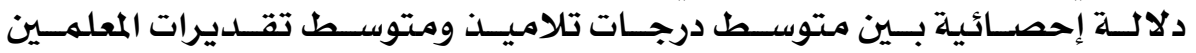

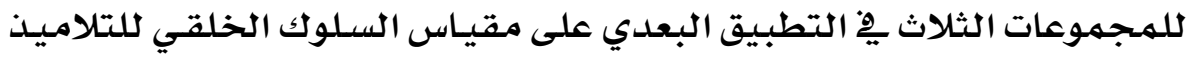

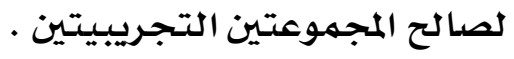

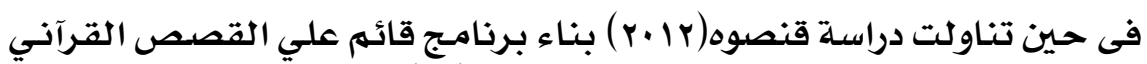

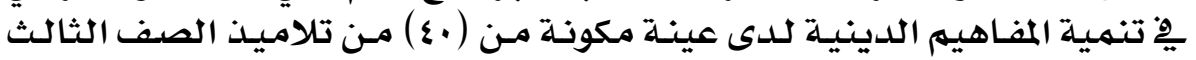

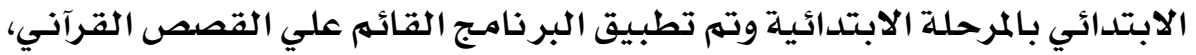

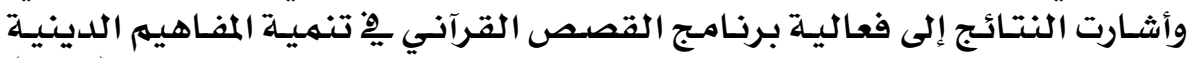

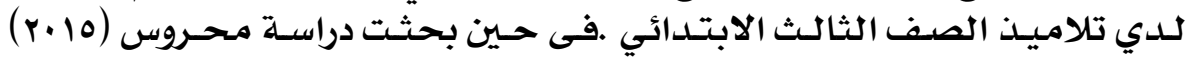

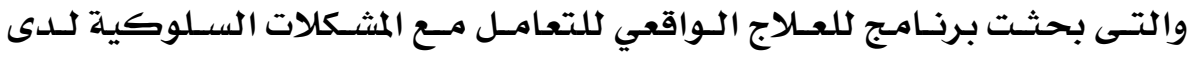

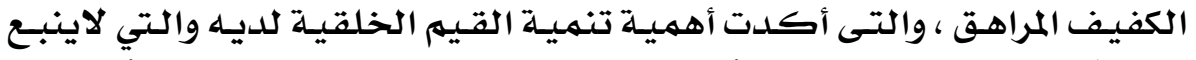

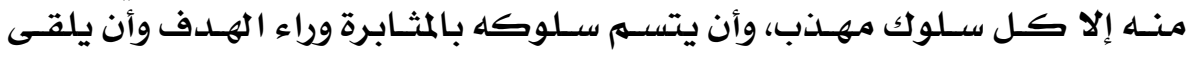

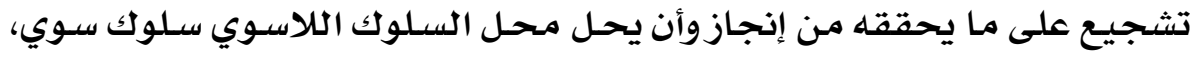

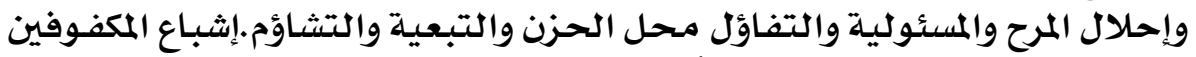

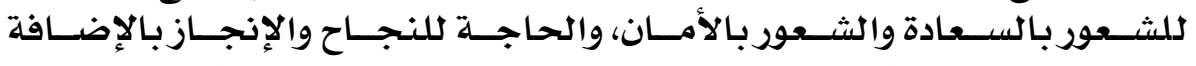

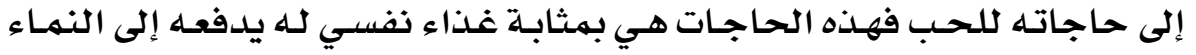

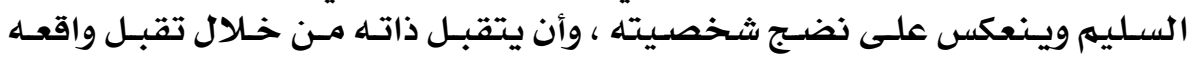

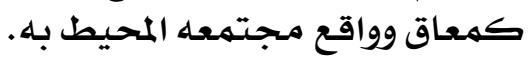

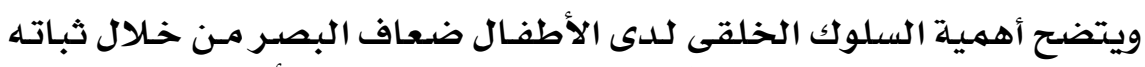

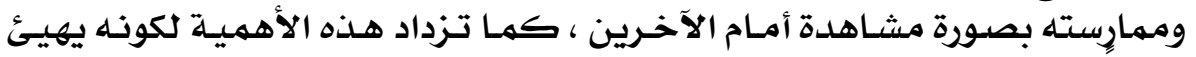

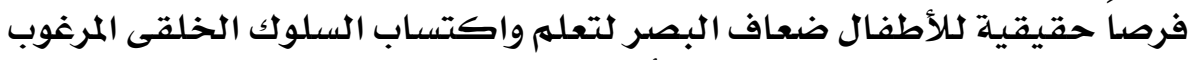

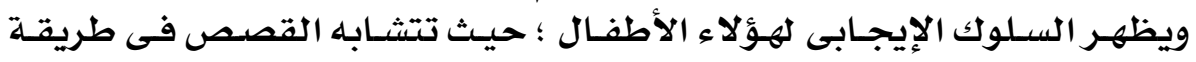

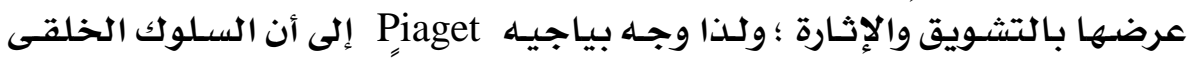

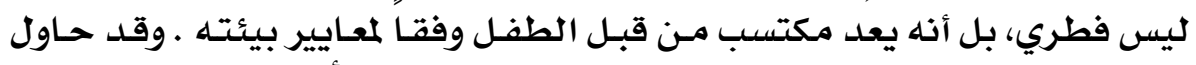

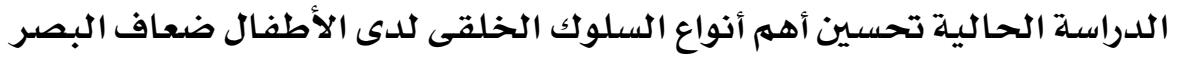

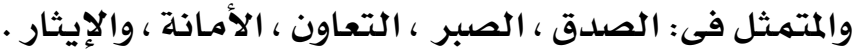

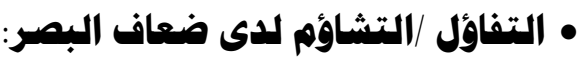

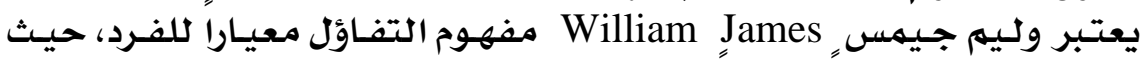

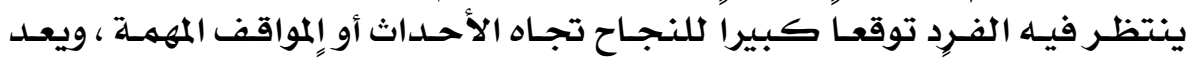

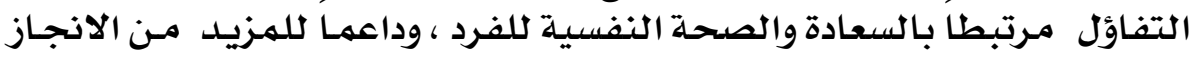

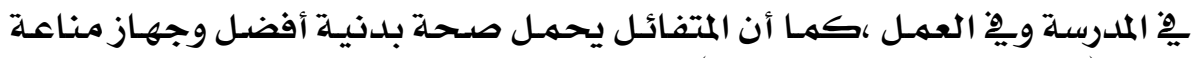

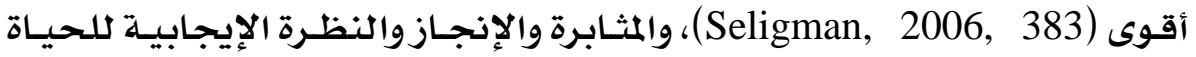

\section{YIV}


العكد التزاسع والخمسول ..الجزء الثمانىى.. هارس ..

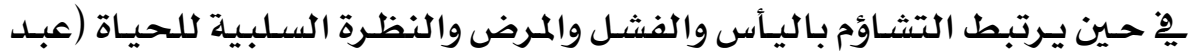

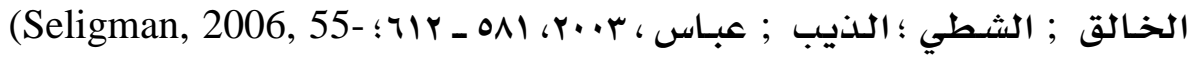

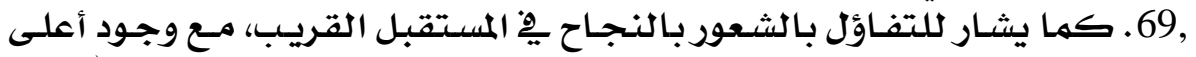

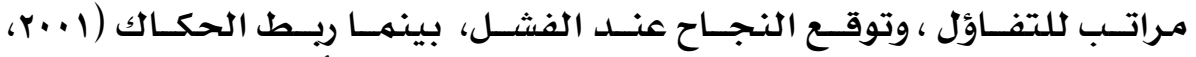

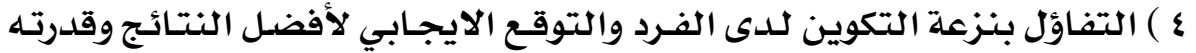

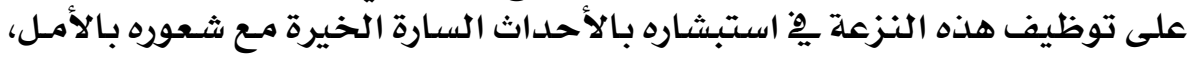
والصحة والسعادة.

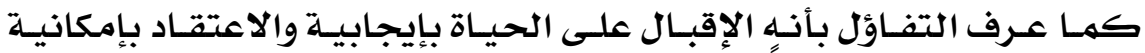

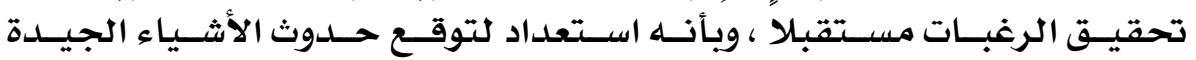

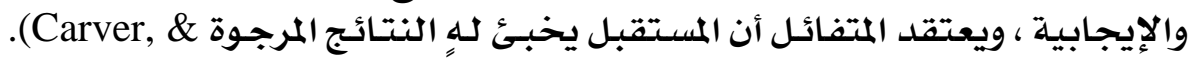

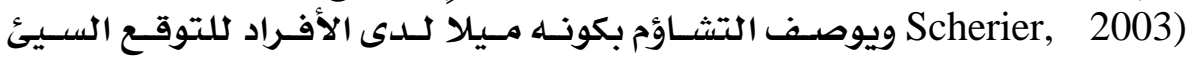
كلأحداث المتوقع حدوثها في المستقبل.

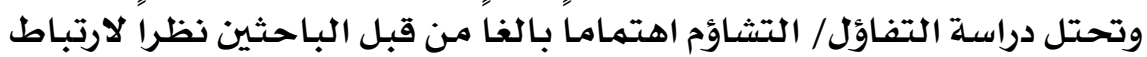

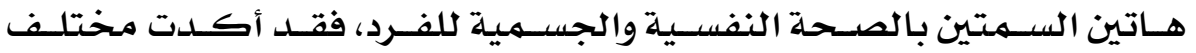

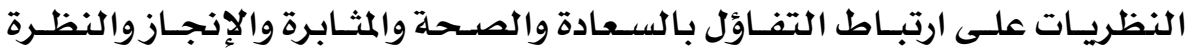

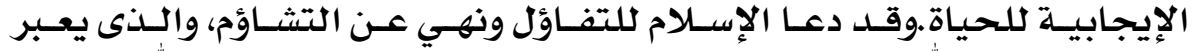

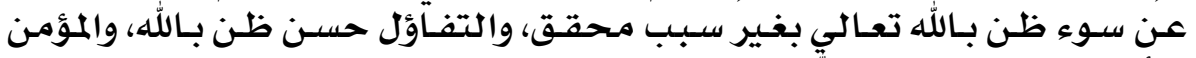

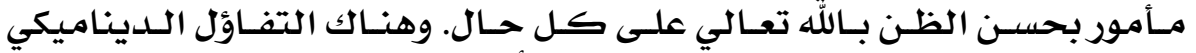

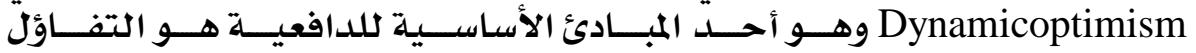

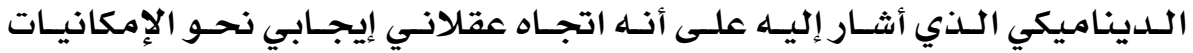

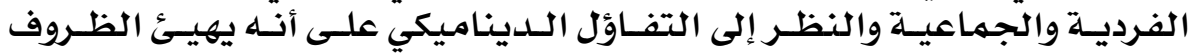

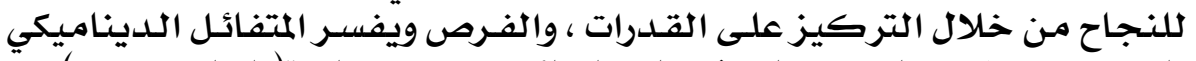

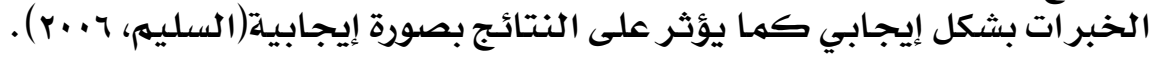

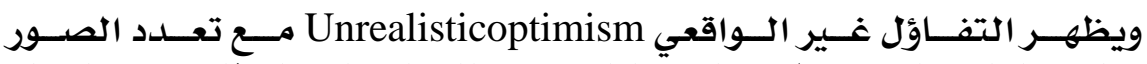

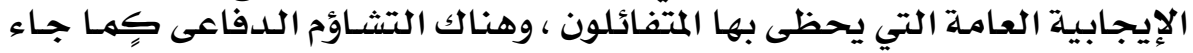

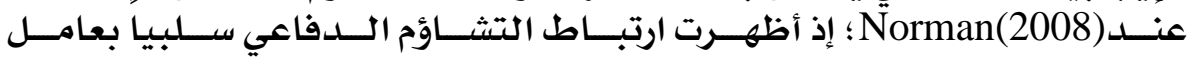

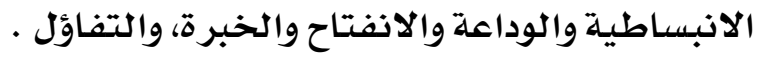

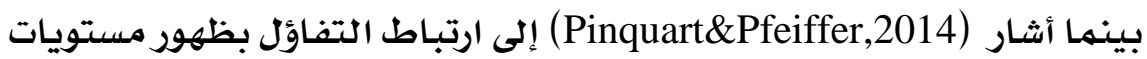

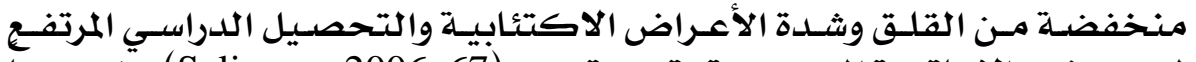

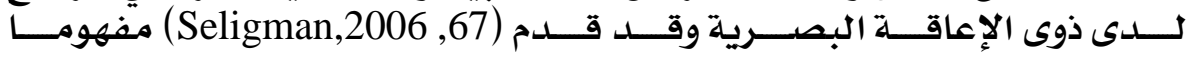

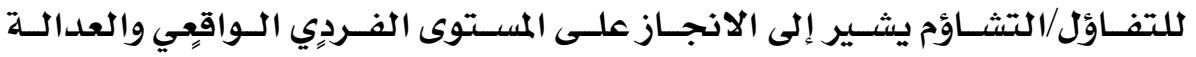

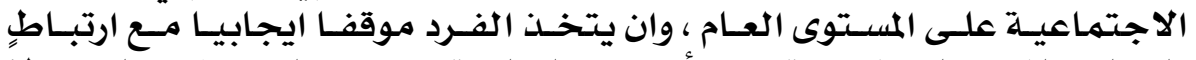

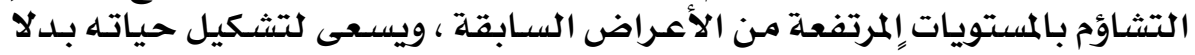

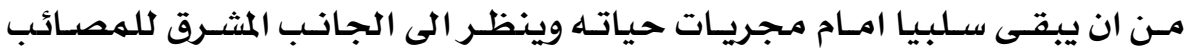

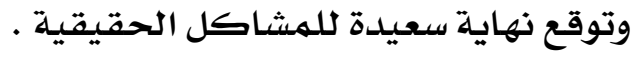

\section{YIA}




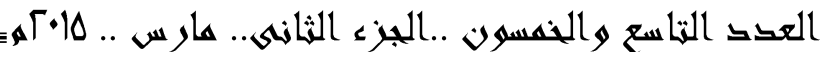

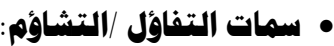

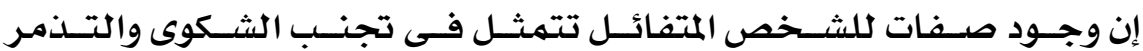

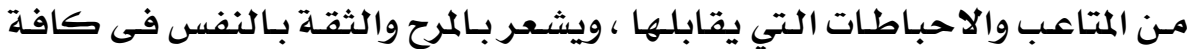

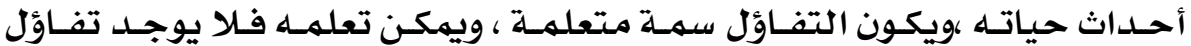

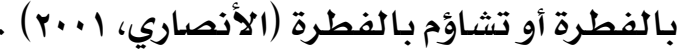

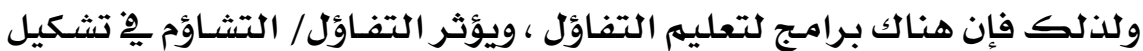

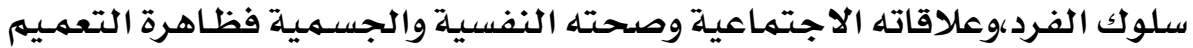

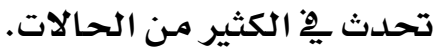

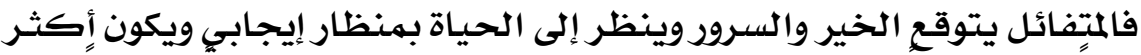

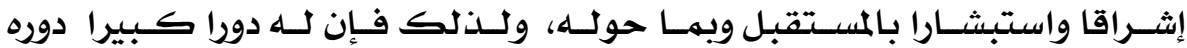

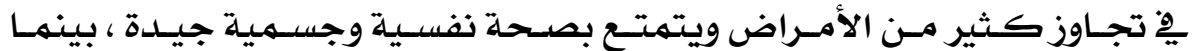

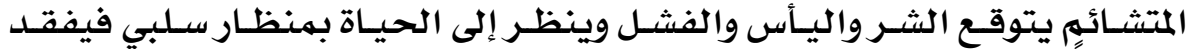

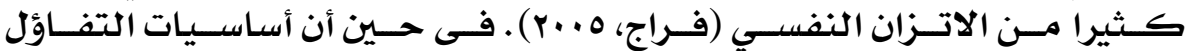

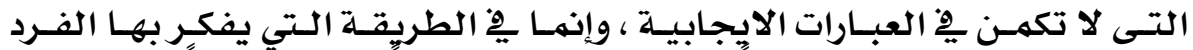

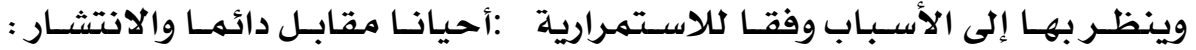

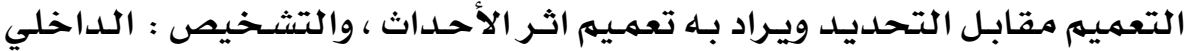

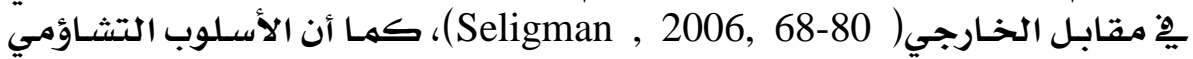
قد يؤدي إلى بث القلق والتوتر والضغوط النفسية.

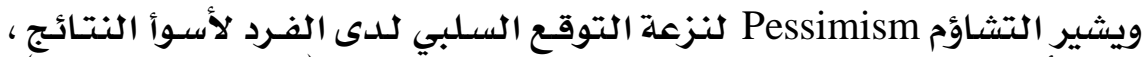

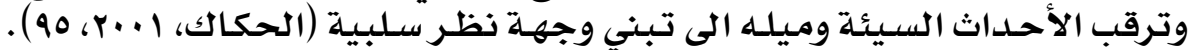

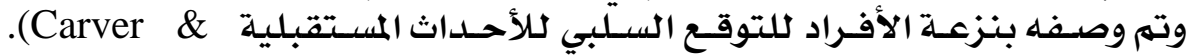
Scherier, 2003)

• • النظريات المفرة للتفاؤل / التشاؤم :

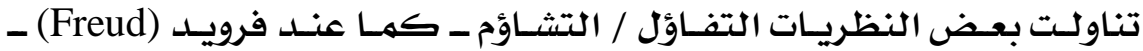

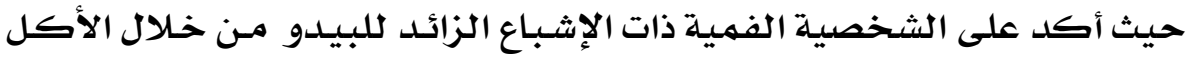

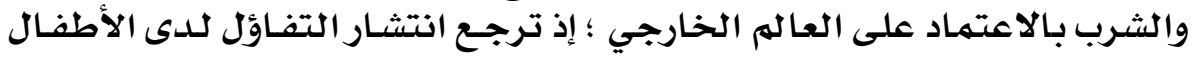

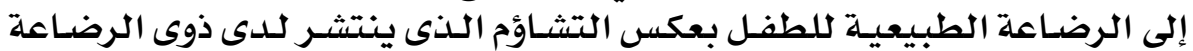

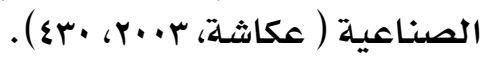

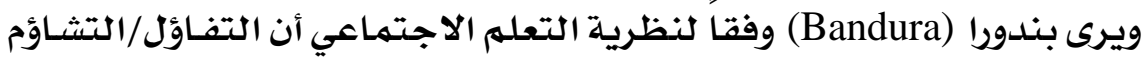

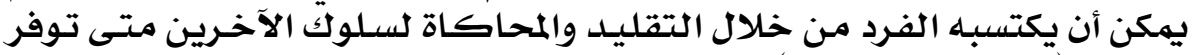

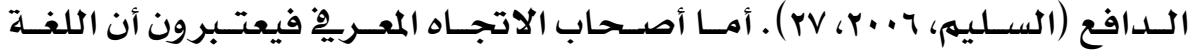

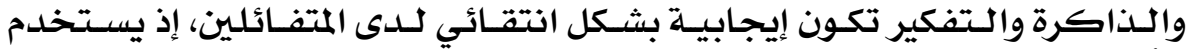

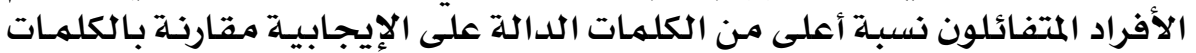

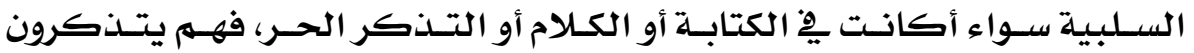

\section{Y) 9}


العكد التزاسع والخمسول ..الجزء الثخانىى.. هارس ..

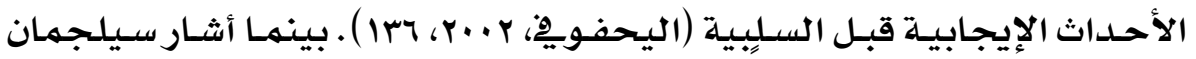

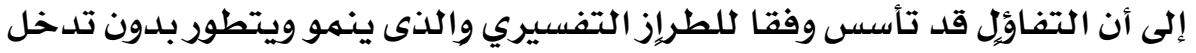

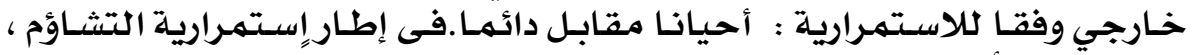

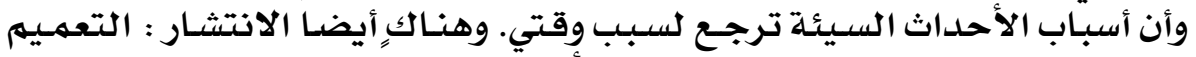

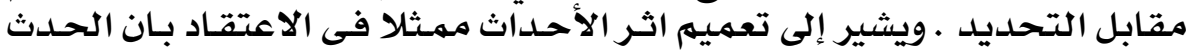

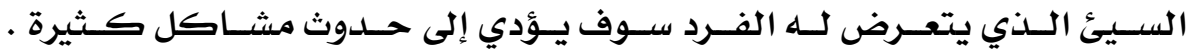

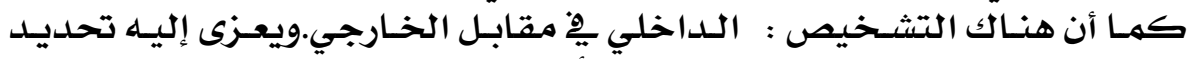

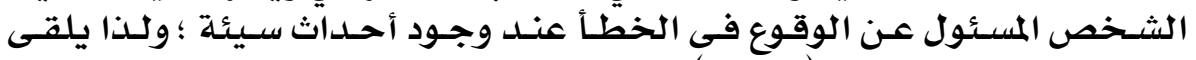

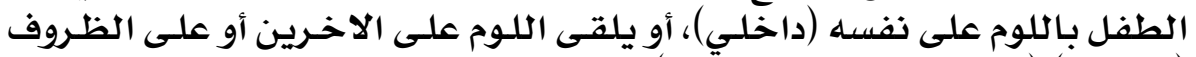

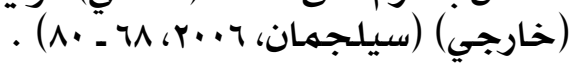

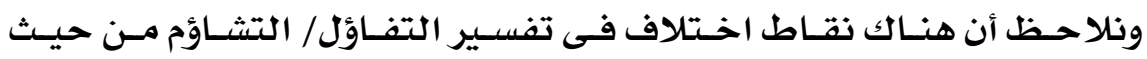

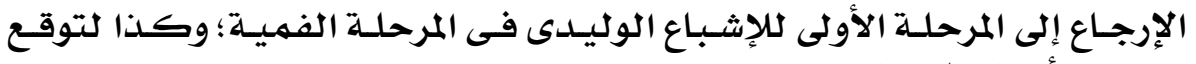

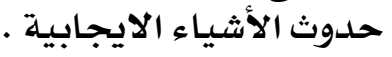

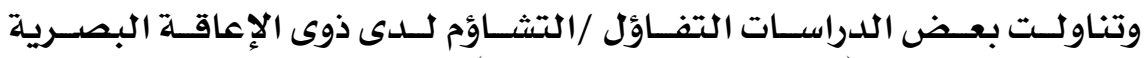

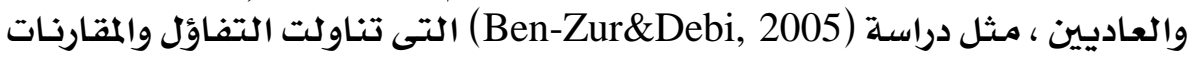

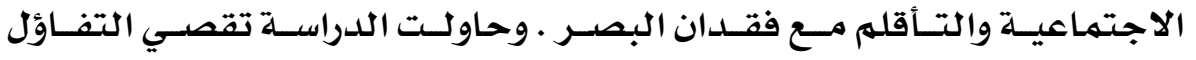

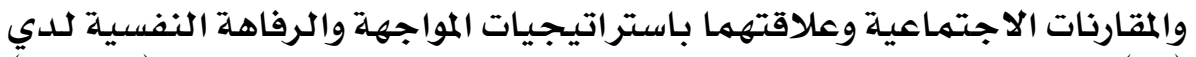

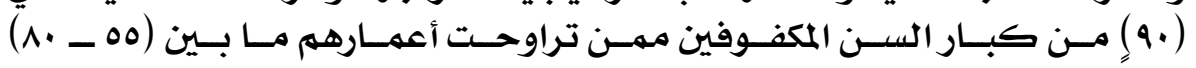

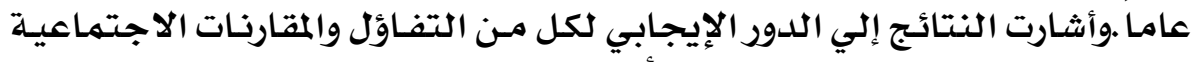

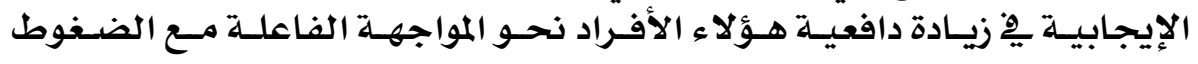

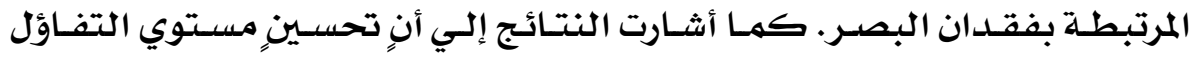

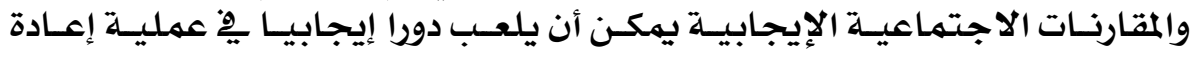
تأهيل المكفوفين.

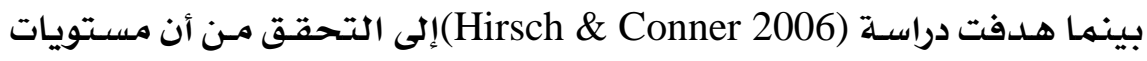

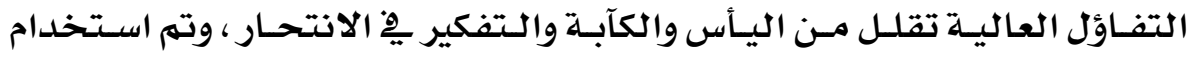

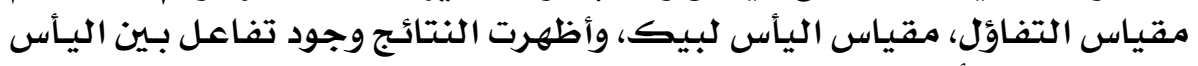

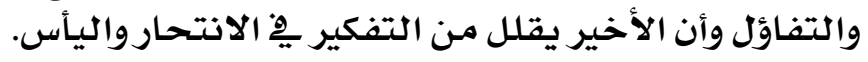

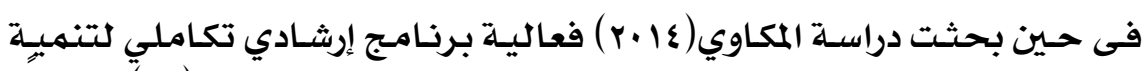

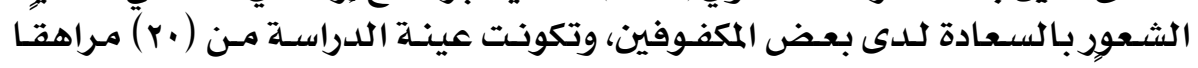

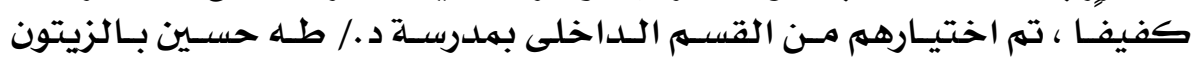

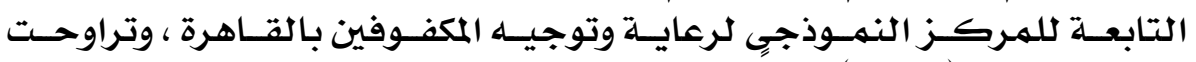

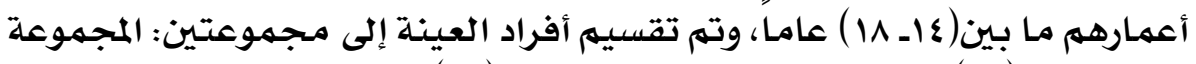

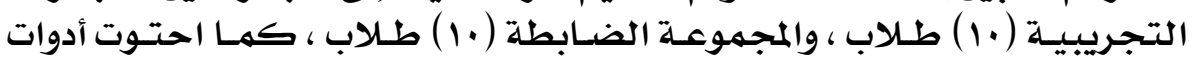

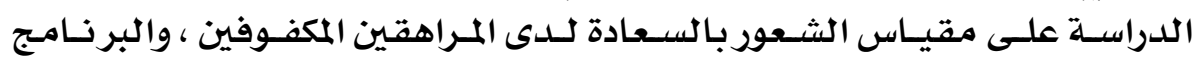

\section{YY.}


العكد التزاسع والخمسول ..الجزء الثخانىى.. هارس ..

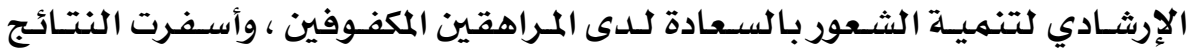

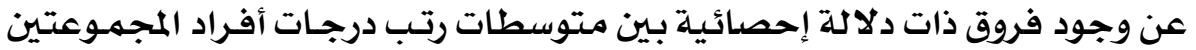

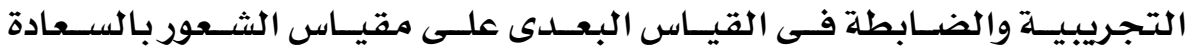

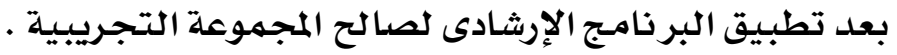

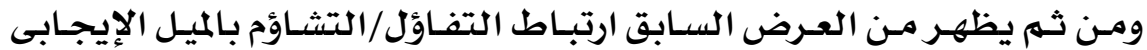

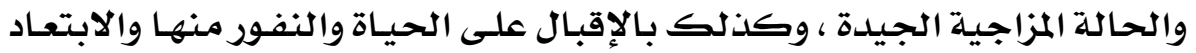

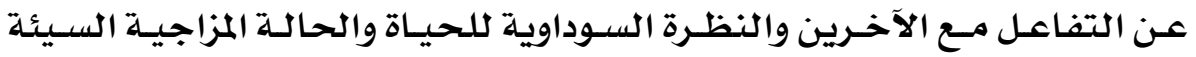

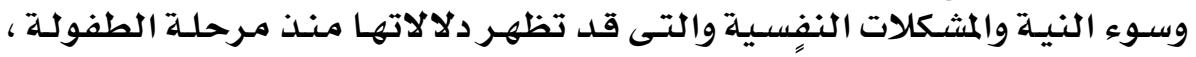

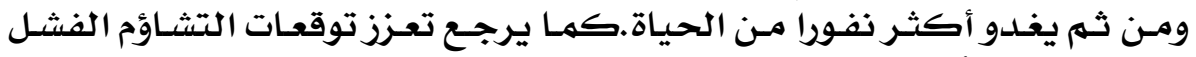

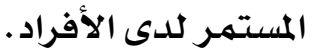

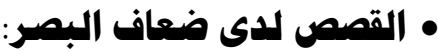

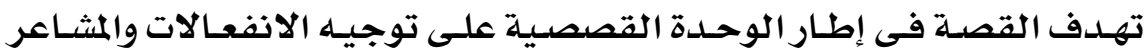

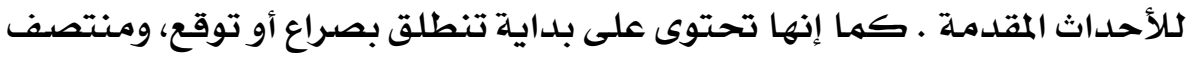

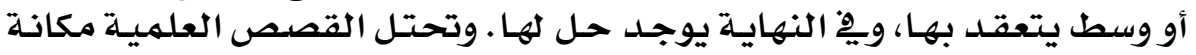

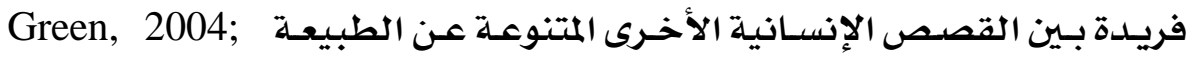
. Yulianty\&Premadi, 2009, 173؛Egan, 2007

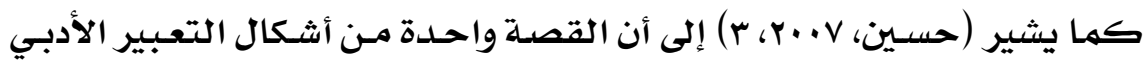

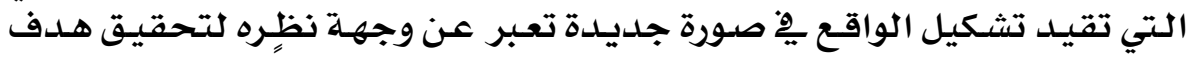

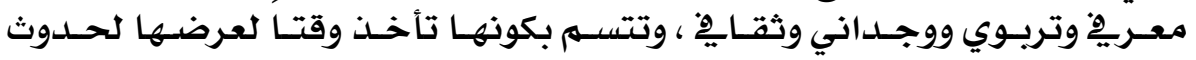

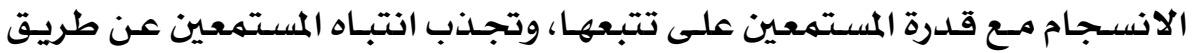

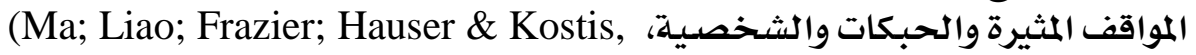
.2014, 1)

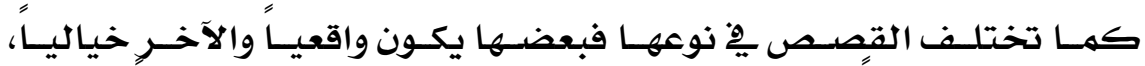

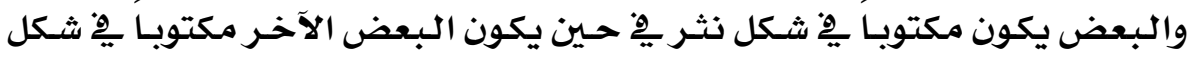
شعر ، والبعض يبث التعجب والتفكير . (Zazkis\& Liljedahl, 2009, 4- 5)

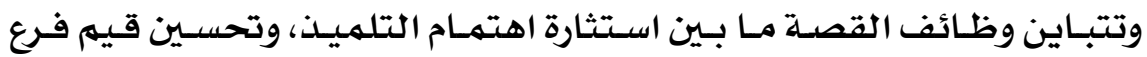
من فروع المعرفة، وريط التتلاميذ الحاليين بمعتقدات المجتئمـع (Green, 2004,2).

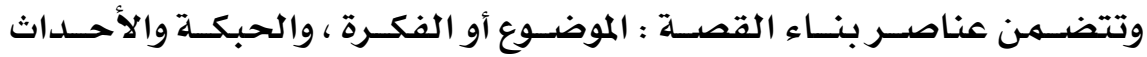

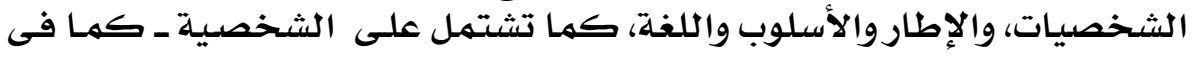

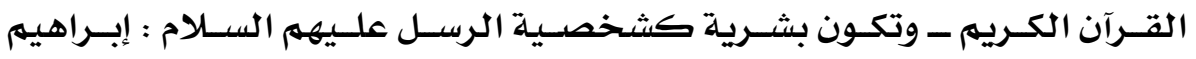

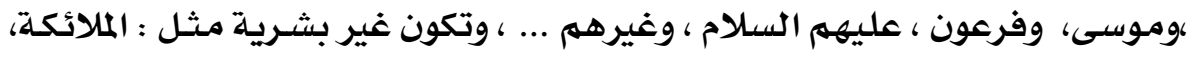

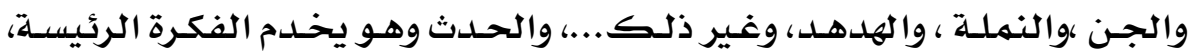

\section{YYI}


العكد التزاسع والخمسول ..الجزء الثخانىى.. هارس ..

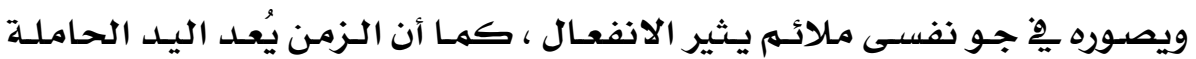

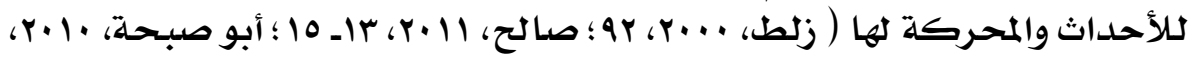

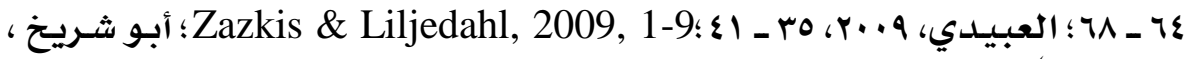
. ( $r q$ ، r. .०

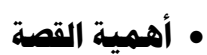

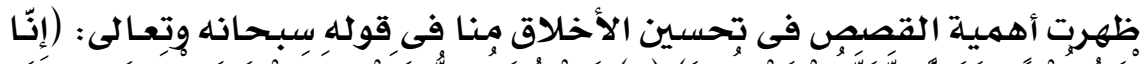

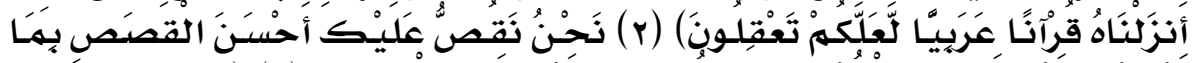

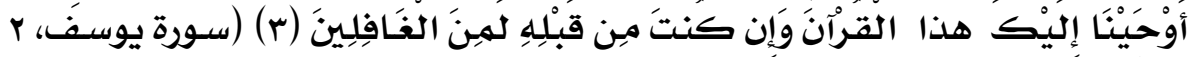

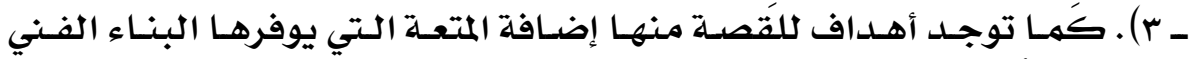

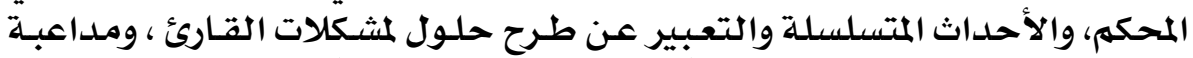

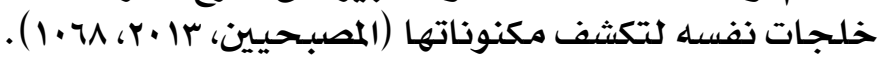

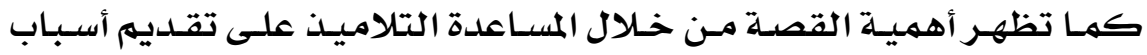

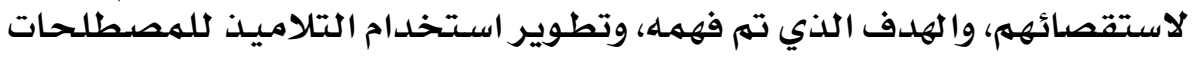

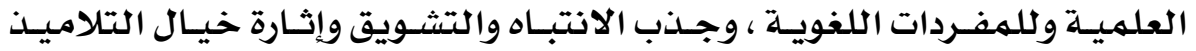

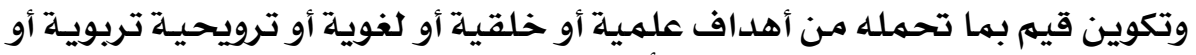

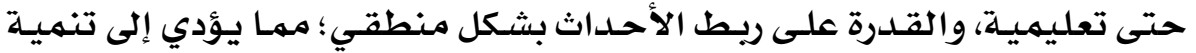

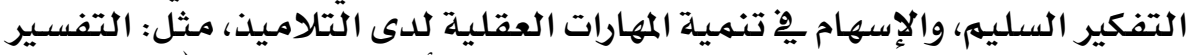

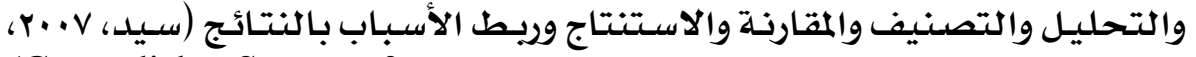

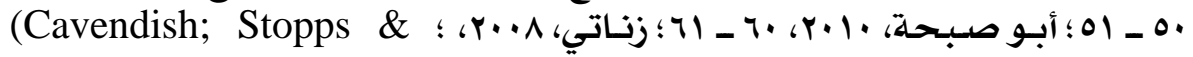
.Ryan, 2006, 20-98)

• أهداف القصة :

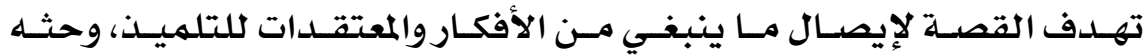

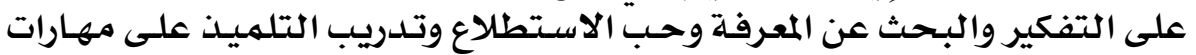

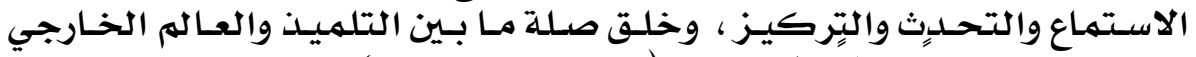

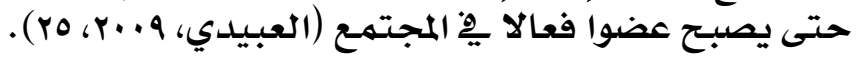

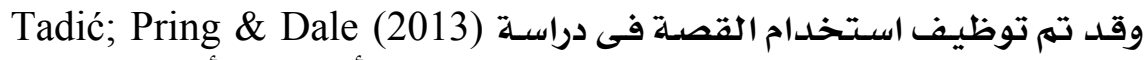

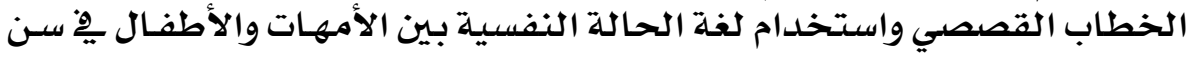

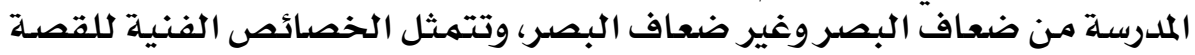

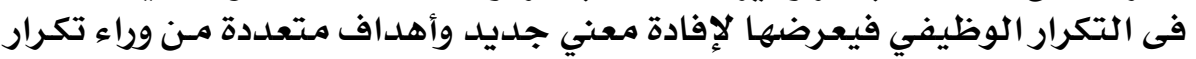

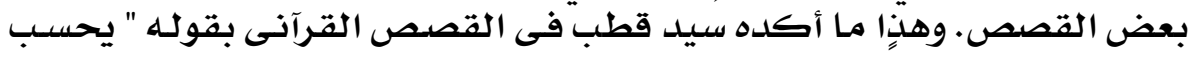

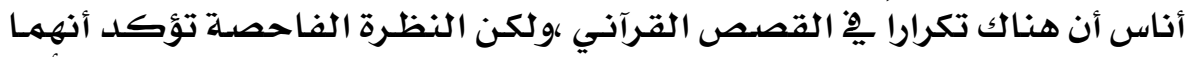

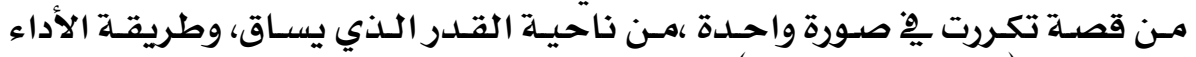

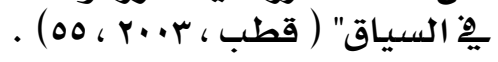

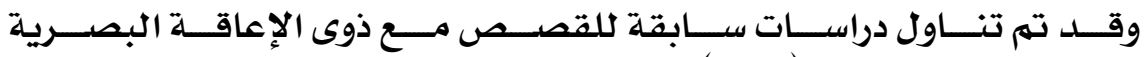

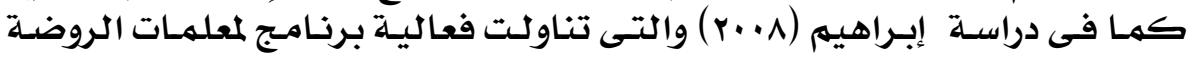

\section{YYY}




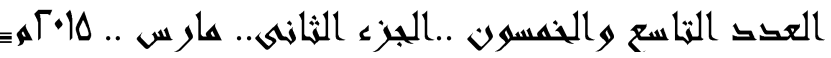

مِّ رواية القصة المعينة على اكتساب الطفل الكفيف مهارات التفاعل مـع البيئسة.

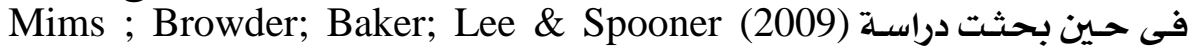

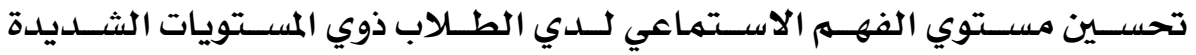

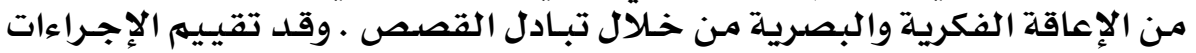

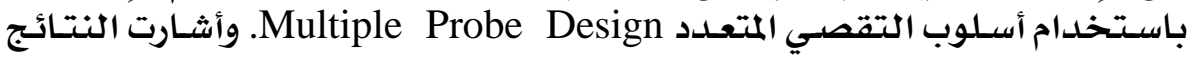

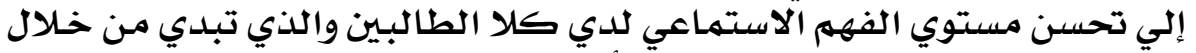

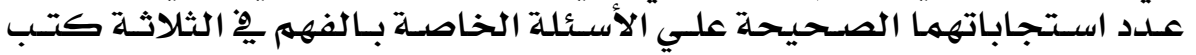

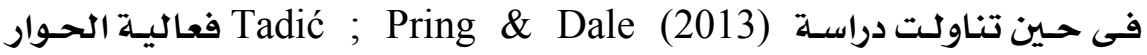

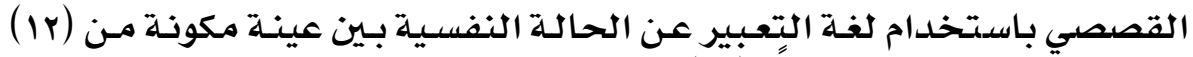

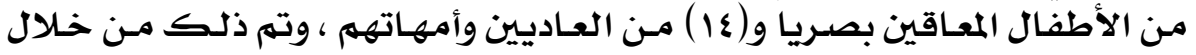

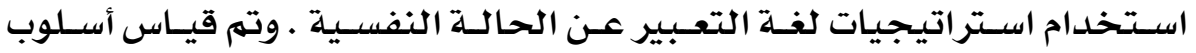

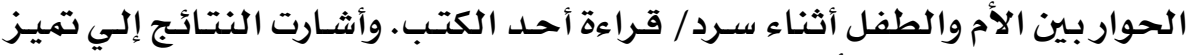

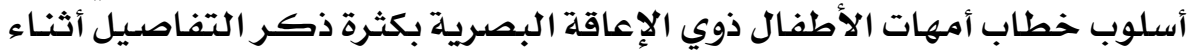

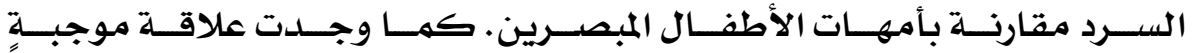

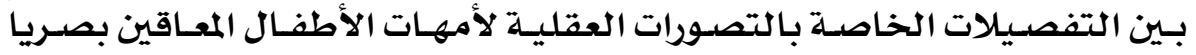

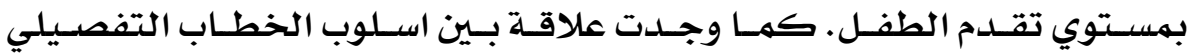

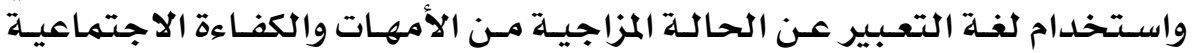

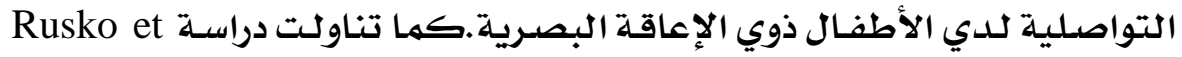

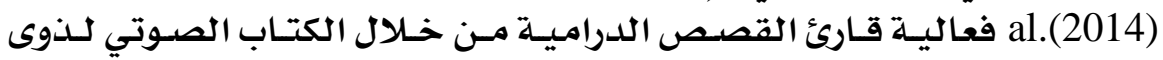

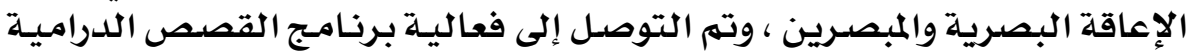

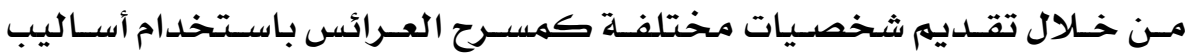
تركيب الكلام.

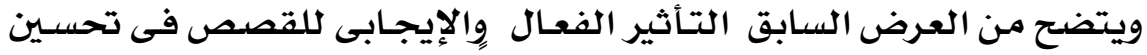

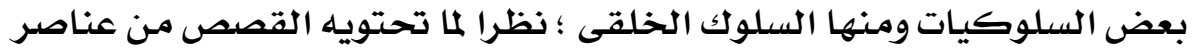

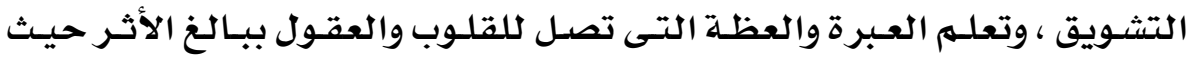

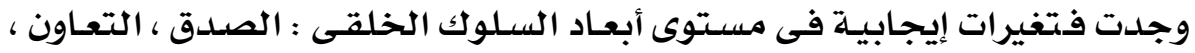
الأمانة ، الصببر ، والإيثار.

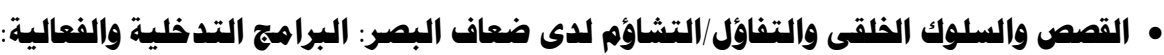

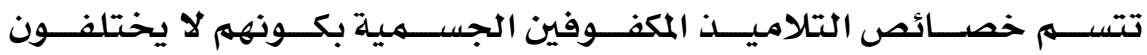

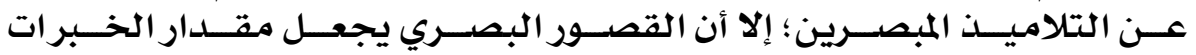

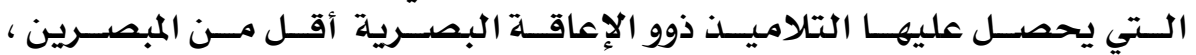

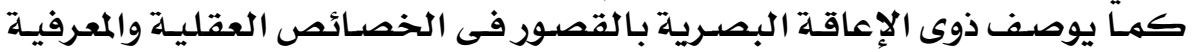

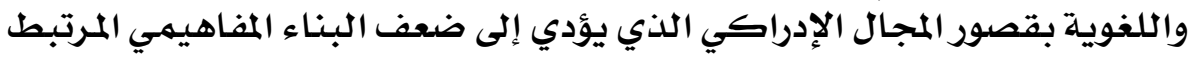

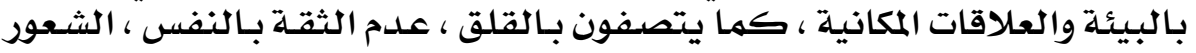

\section{YYY}




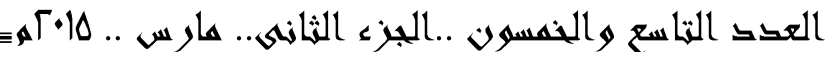

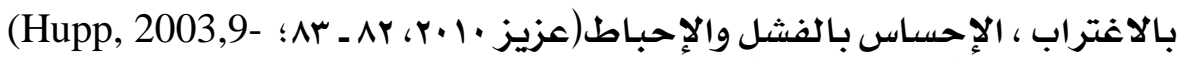

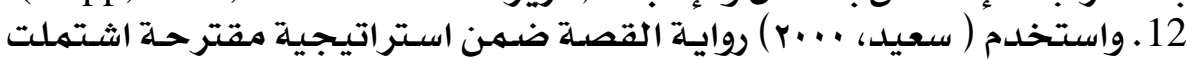

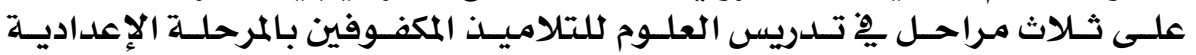

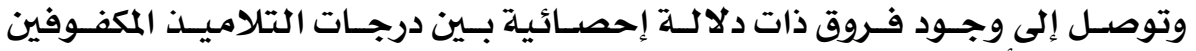

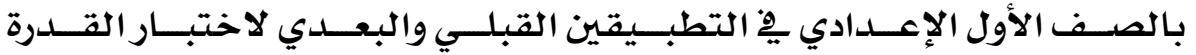

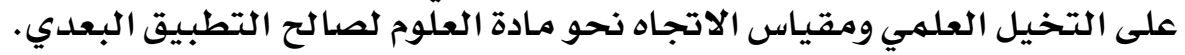

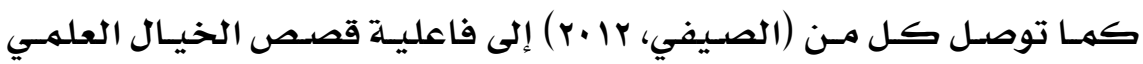

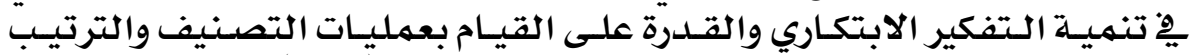

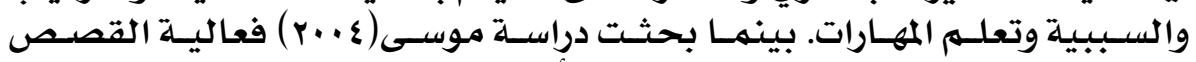

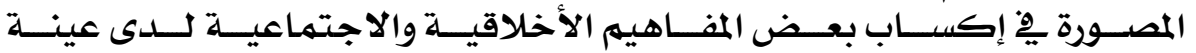

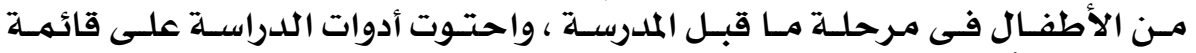

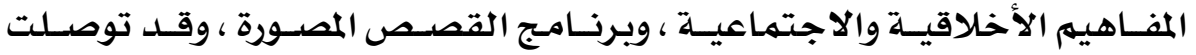

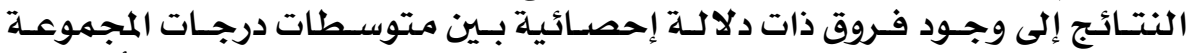

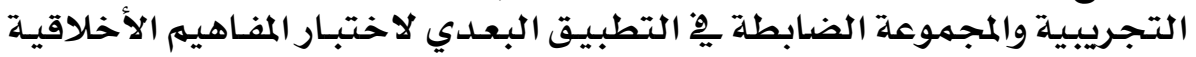

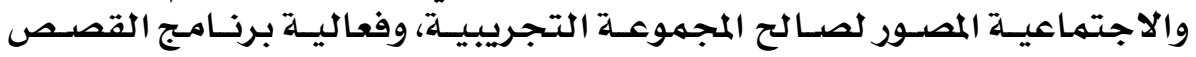
المصورة فِ إكساب بعض المصنور المفاهيه.

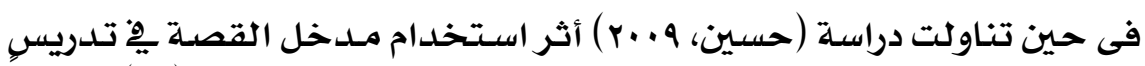

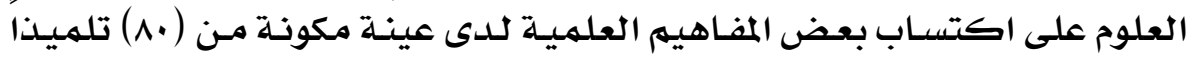

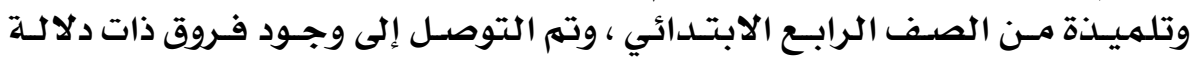

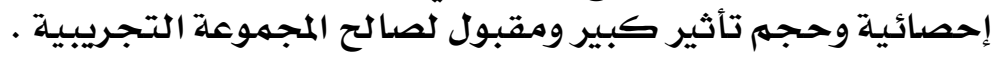

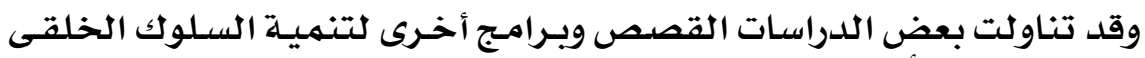

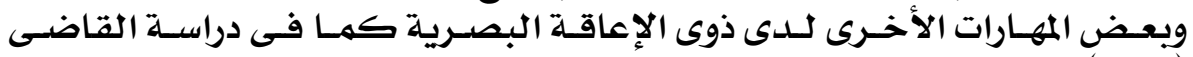

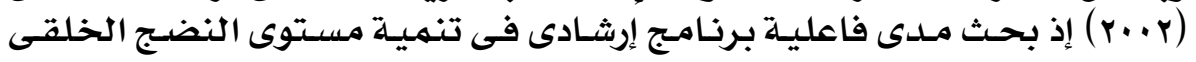

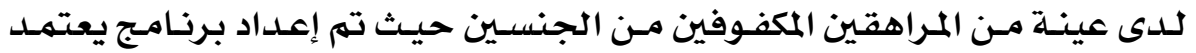

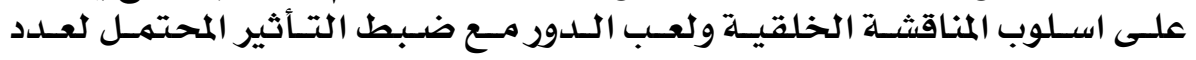

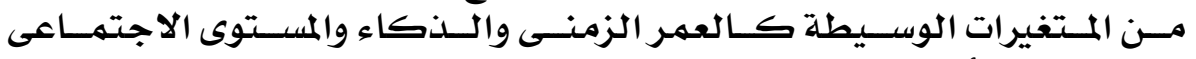

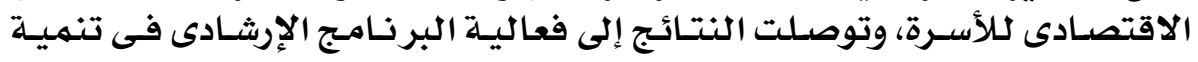
مستوى النضـج الخلقى لدى لدى المكفوفين.

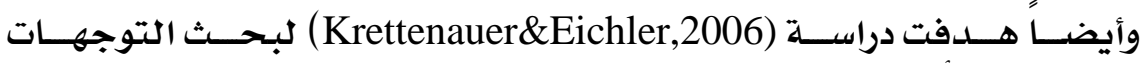

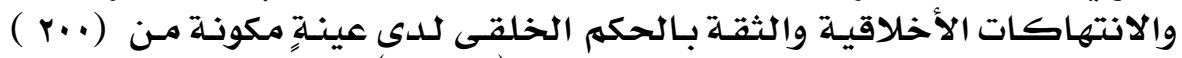

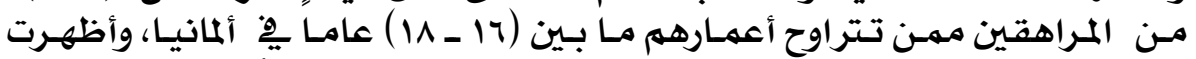

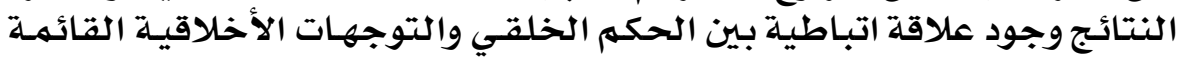

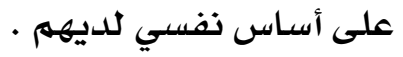

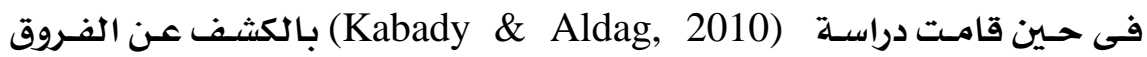

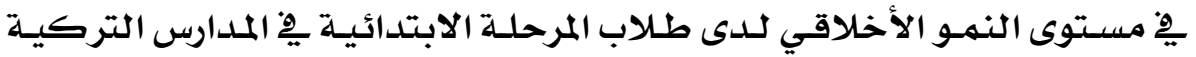

\section{YY\&}




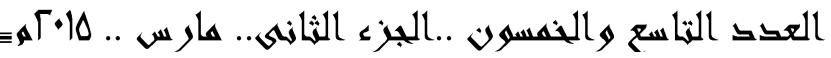

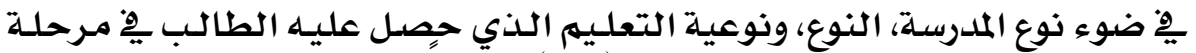

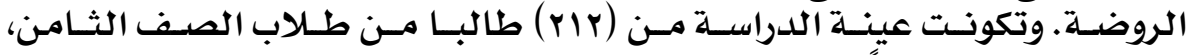

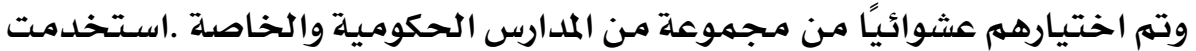

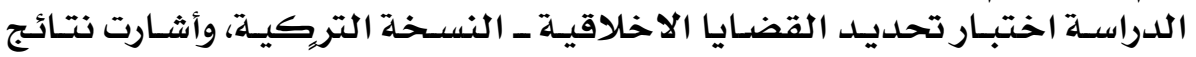

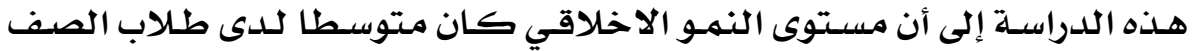

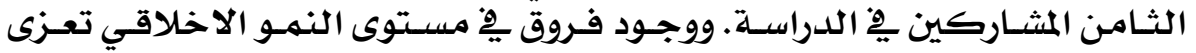

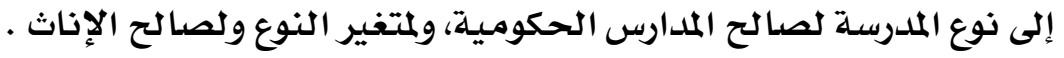

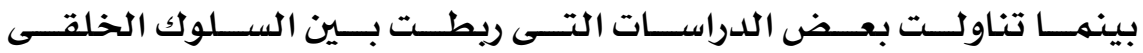

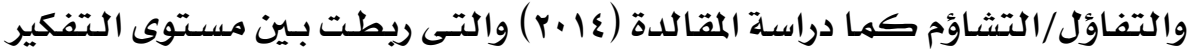

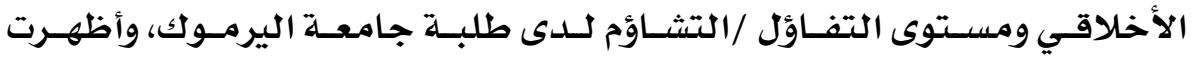

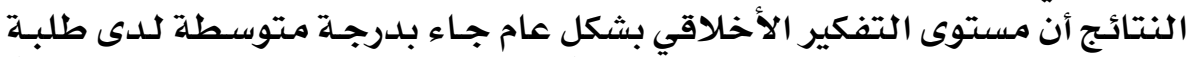

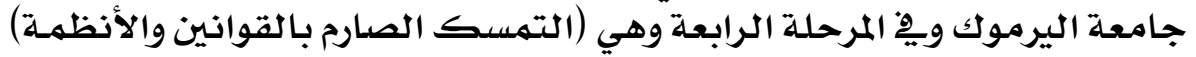

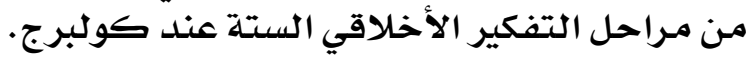

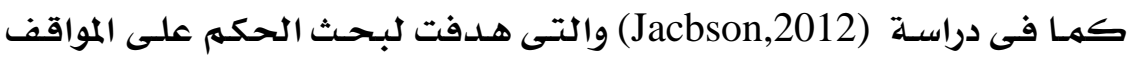

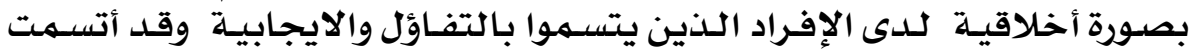

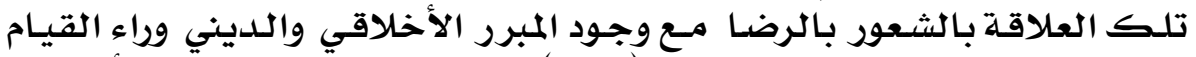

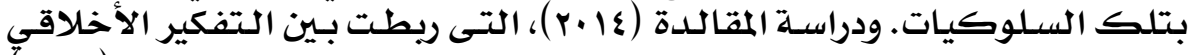

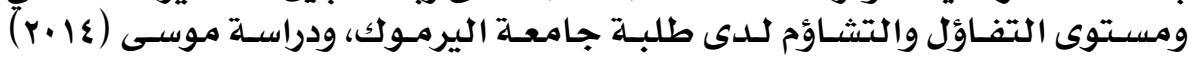

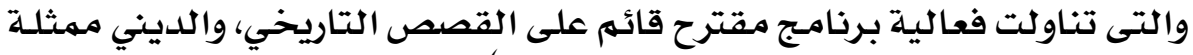

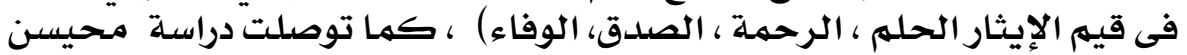

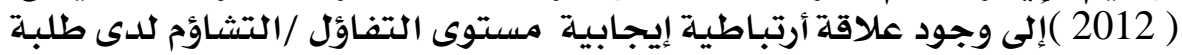

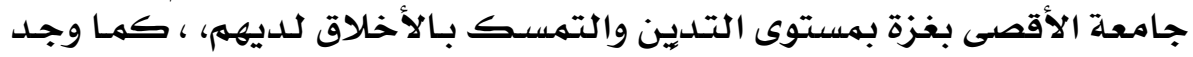

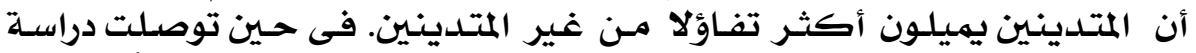

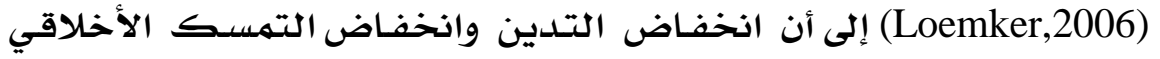

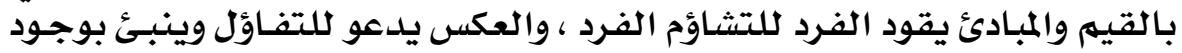
النجاح والسعادة.

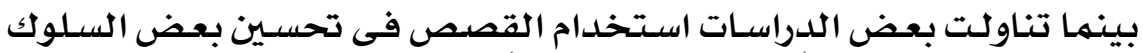

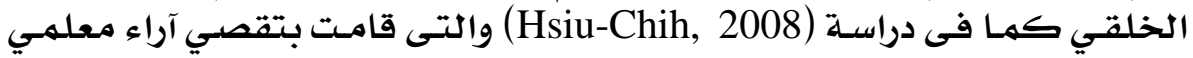

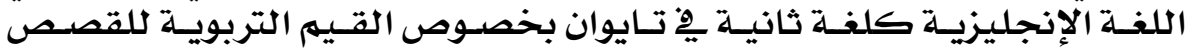

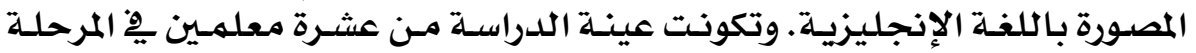

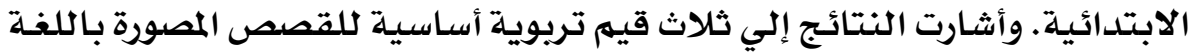

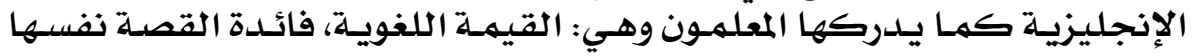

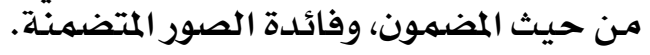

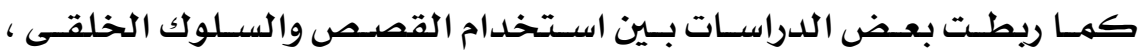

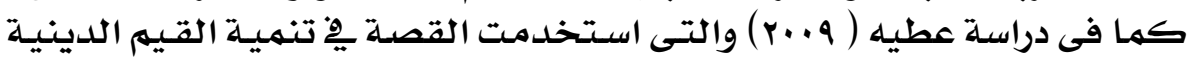

\section{YYO}




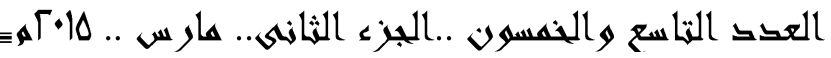

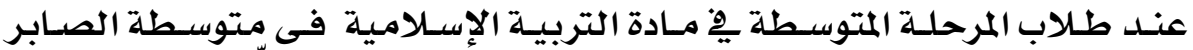

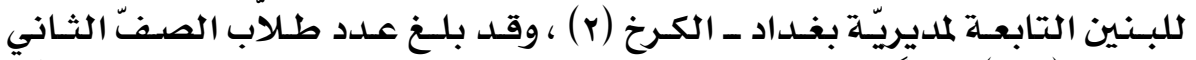

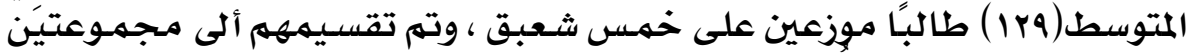

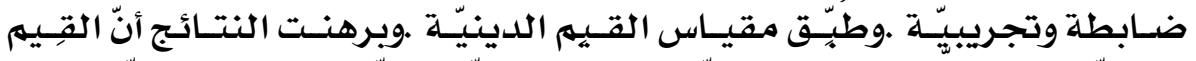

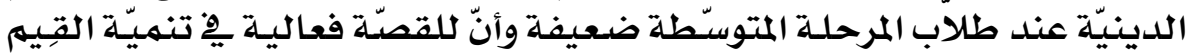

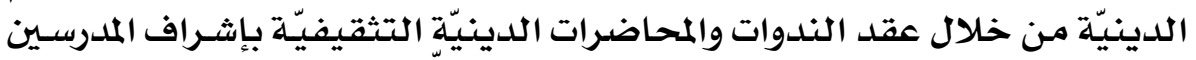

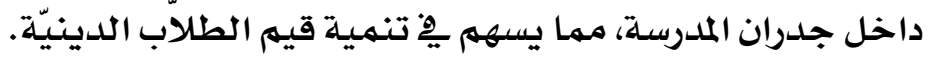

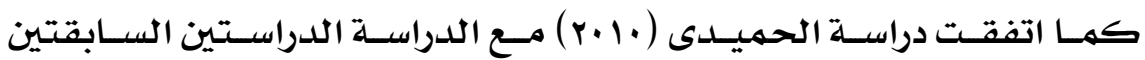

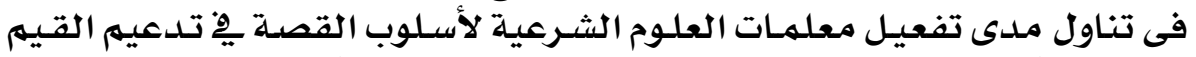

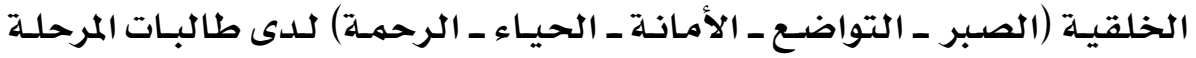

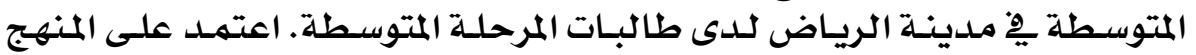

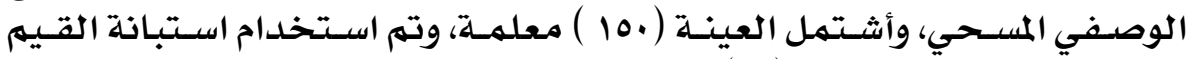

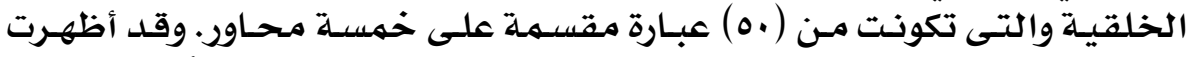

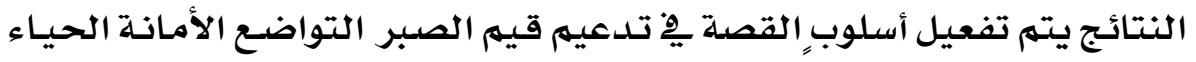

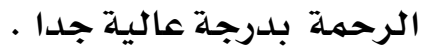

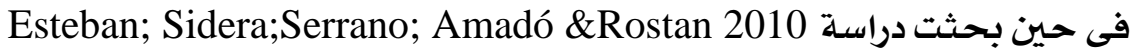

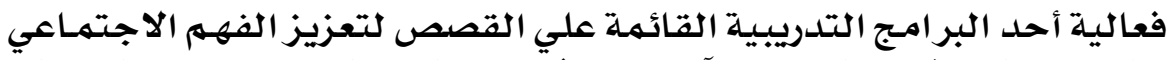

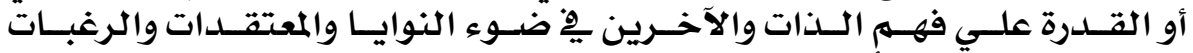

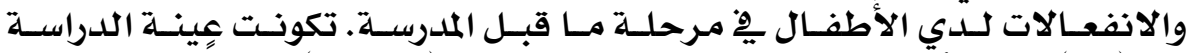

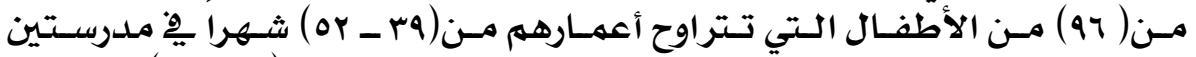

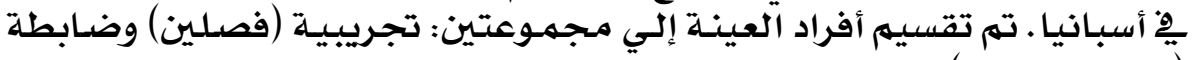

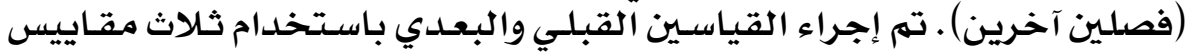

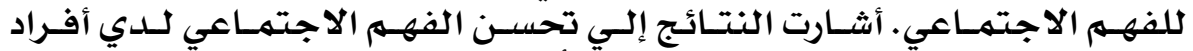

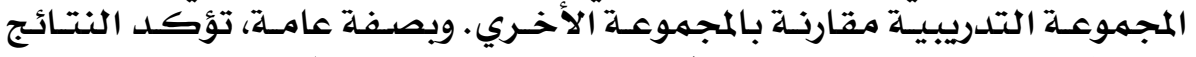

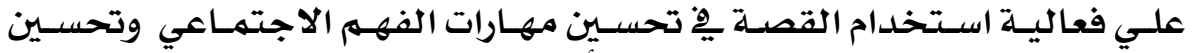

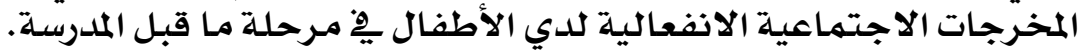

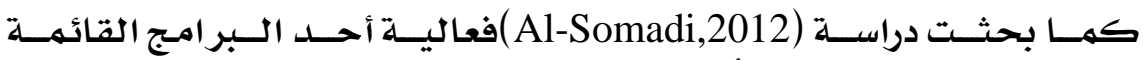

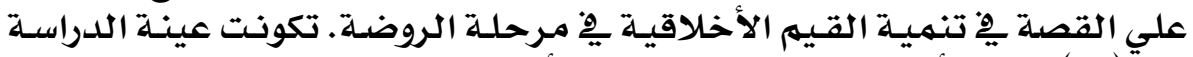

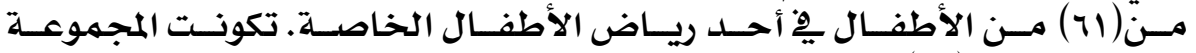

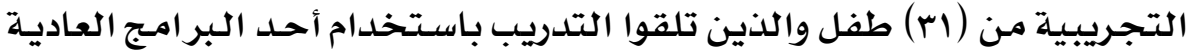

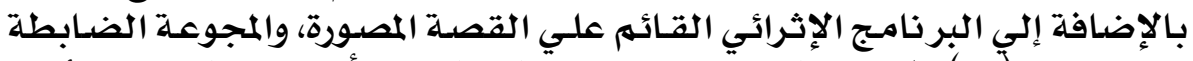

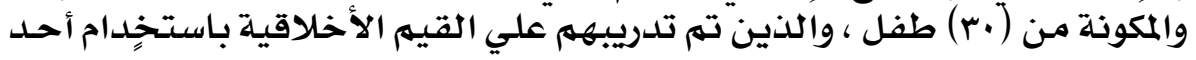

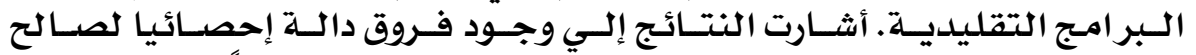

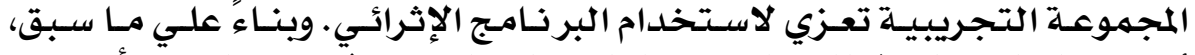

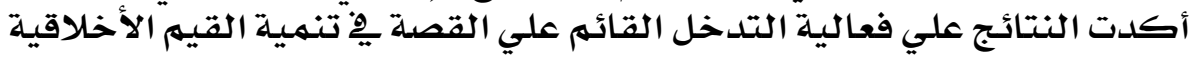

\section{YYT}


العكد التزاسع والخمسول ..الجزء الثخانىى.. هارس ..

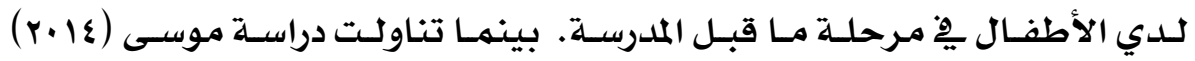

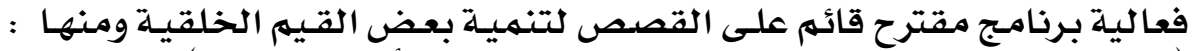

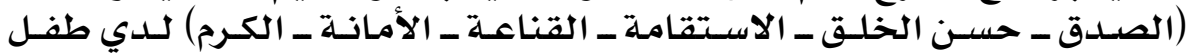
الروضـة.

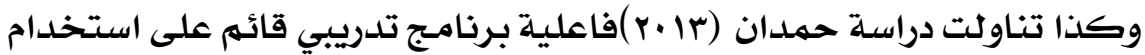

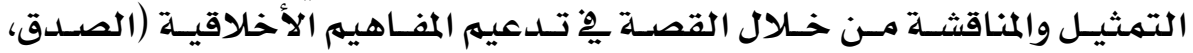

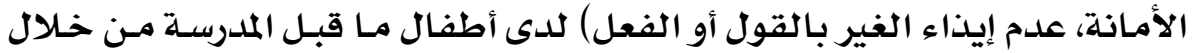

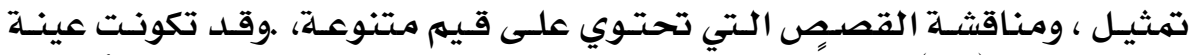

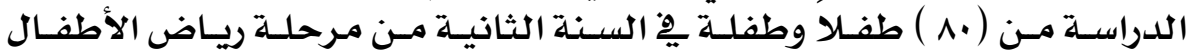

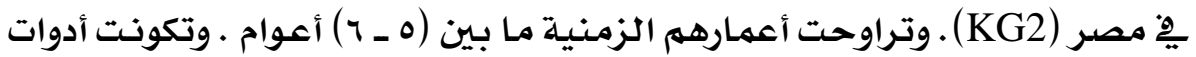

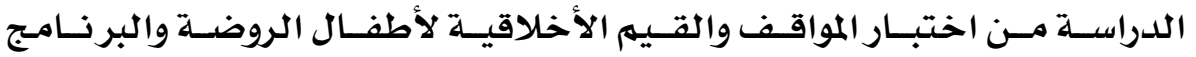

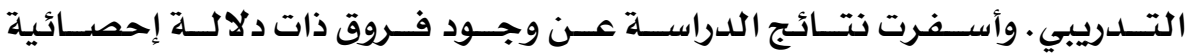

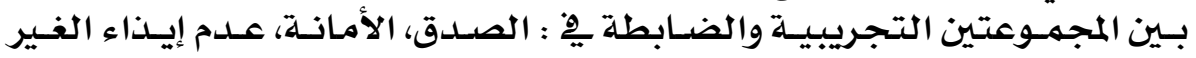

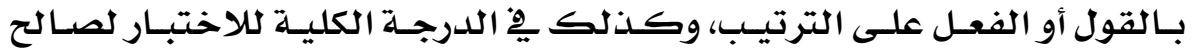

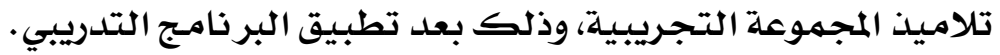

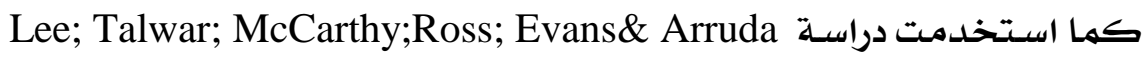

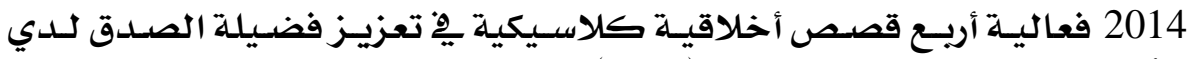

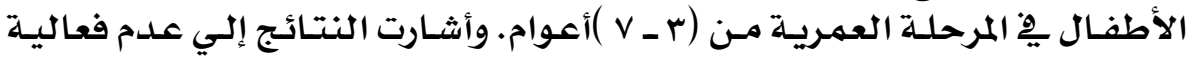

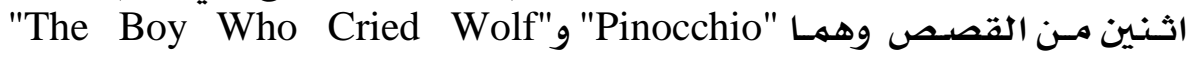

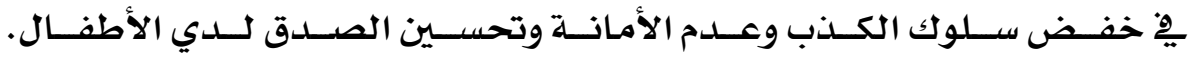

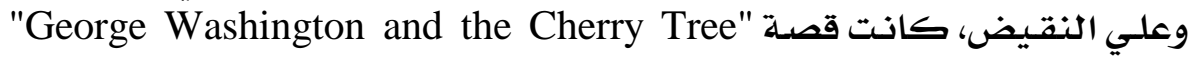

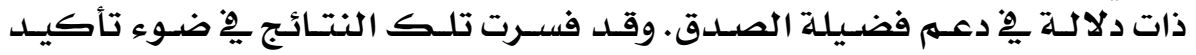

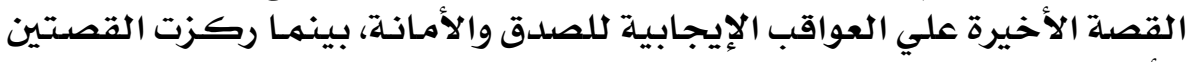

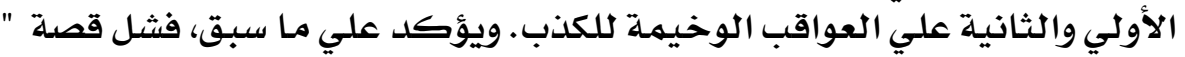

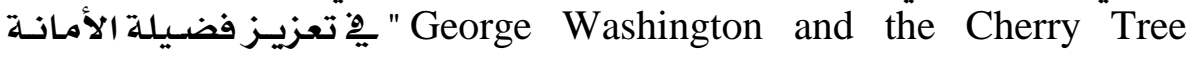
عندما تناولت الآثار السالبة للكذب بخلاف السـابق.

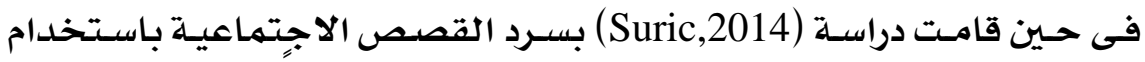

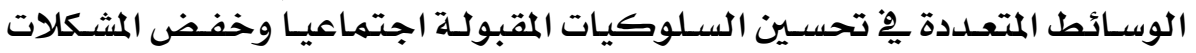

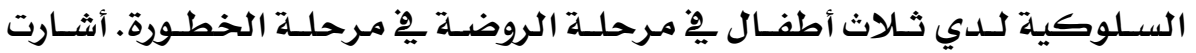

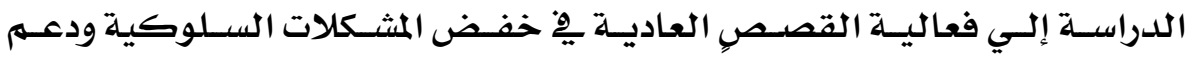

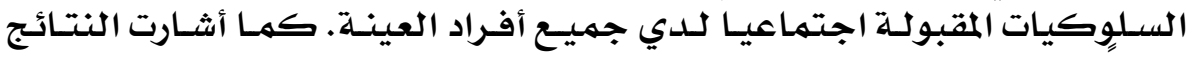

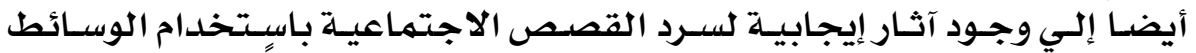

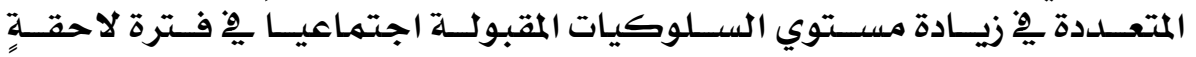

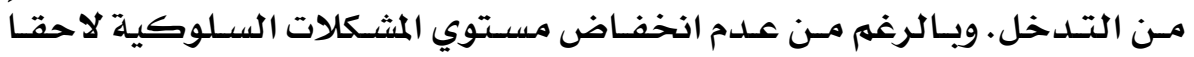

\section{YYV}




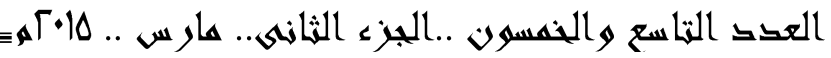

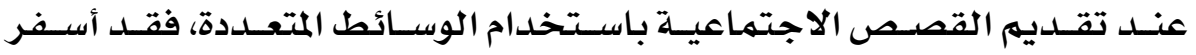

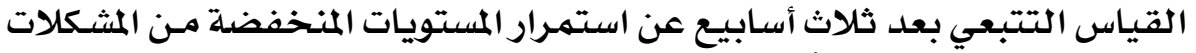

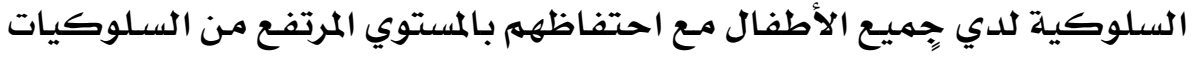
المقبولة اجتمهاعيا.

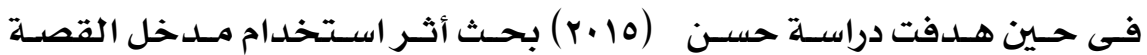

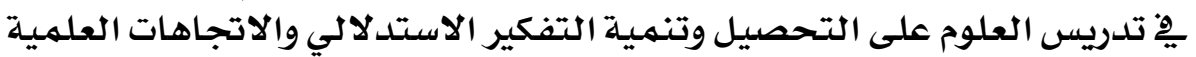

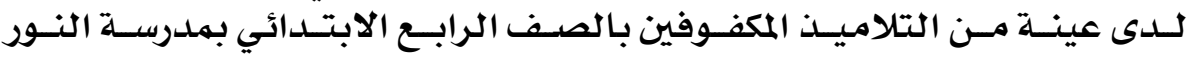

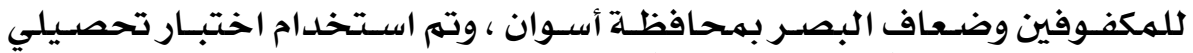

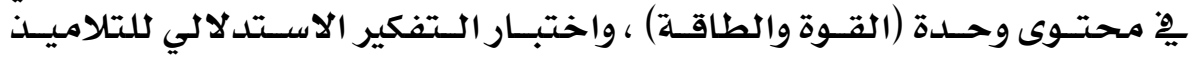

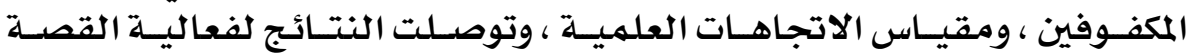

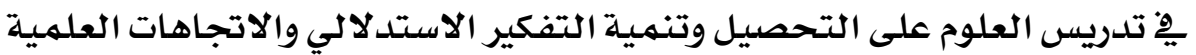
لدى التلاحيذ المكفوفين.

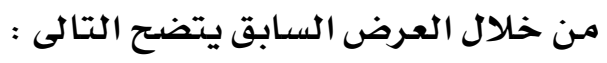

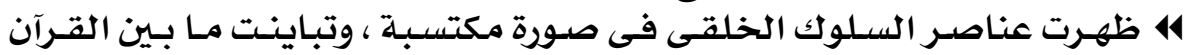

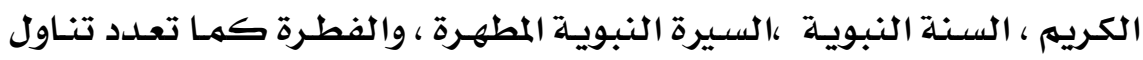

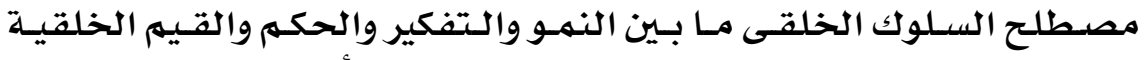

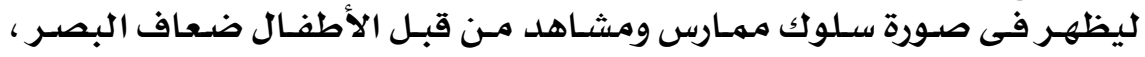

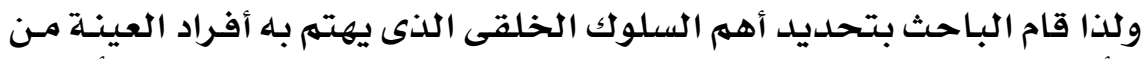

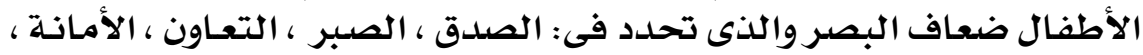

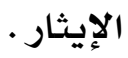

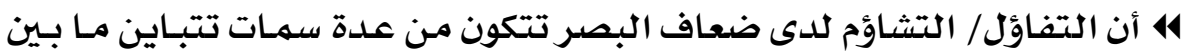

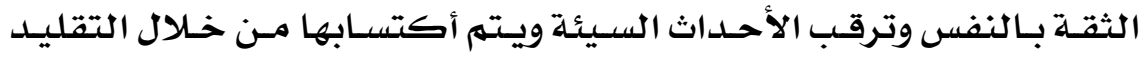

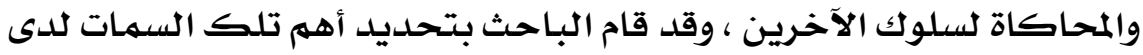

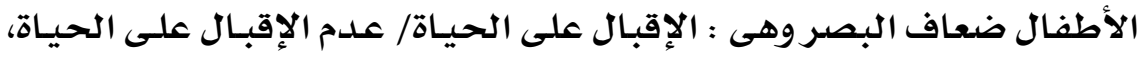

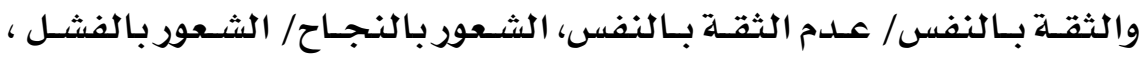

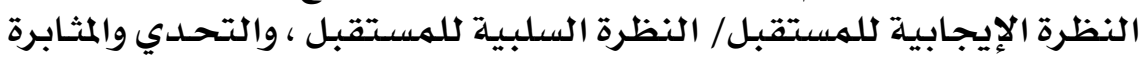

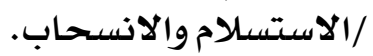

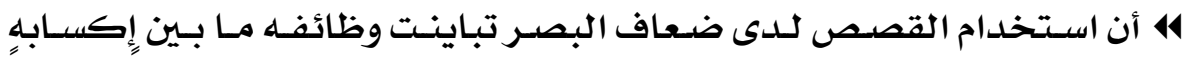

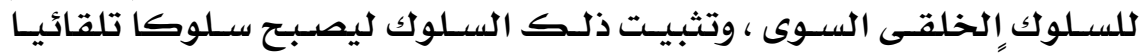

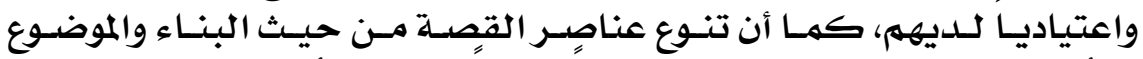

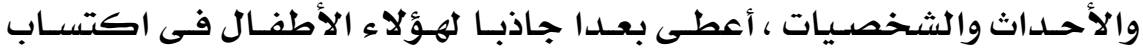

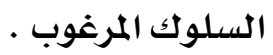

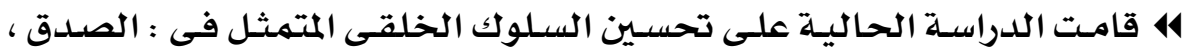

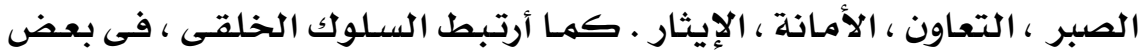

\section{YYA}


العكد التزاسع والخمسول ..الجزء الثخانىى.. هارس ..

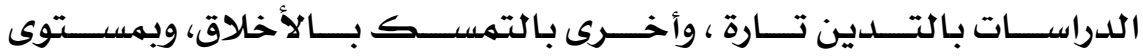

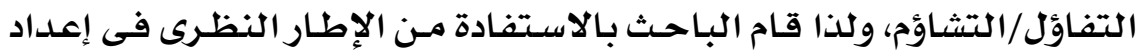

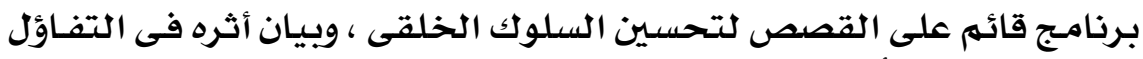

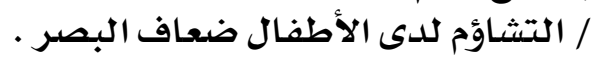

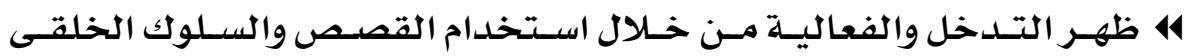

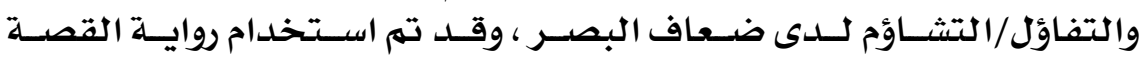

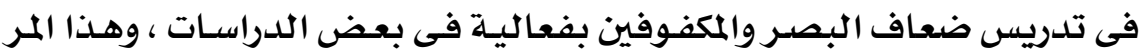

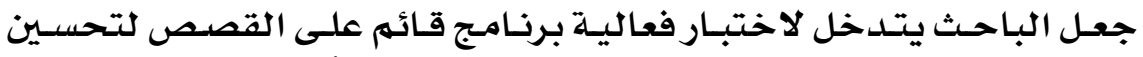

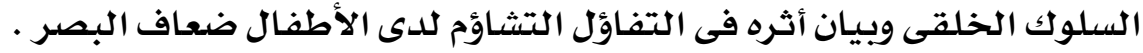

\section{• فروض الدراسة :}

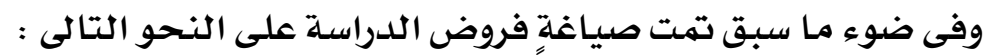

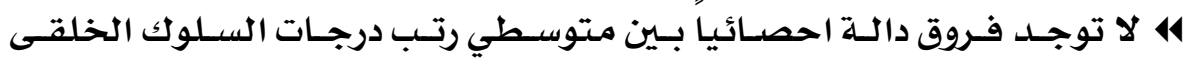

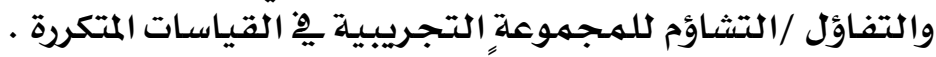

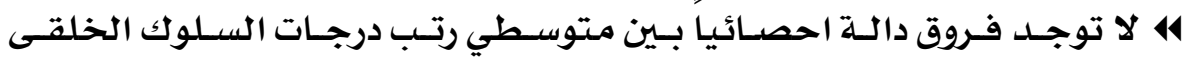

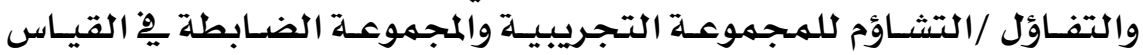

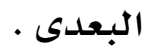

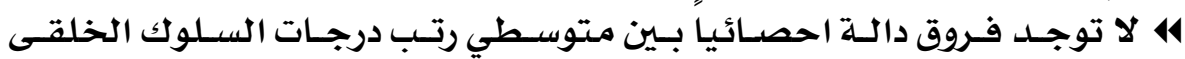

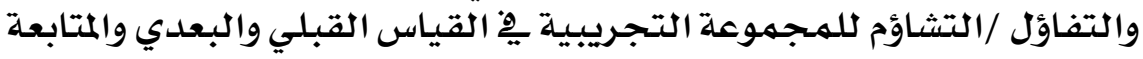

$$
\text { والتتبعى. }
$$

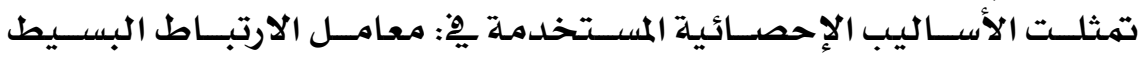

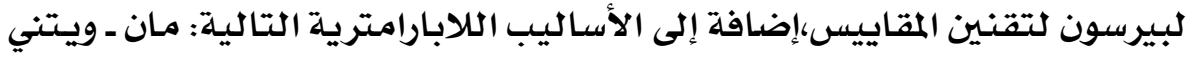

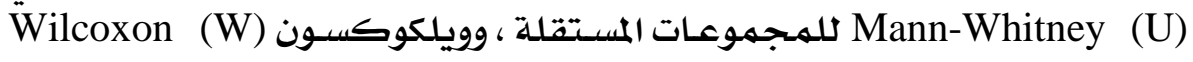

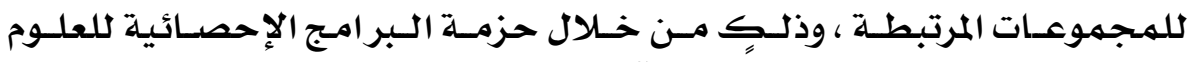

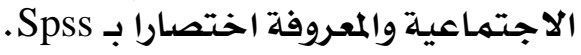

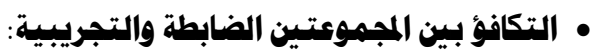

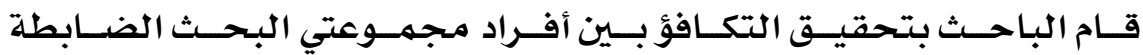

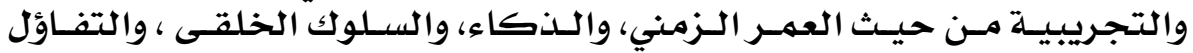

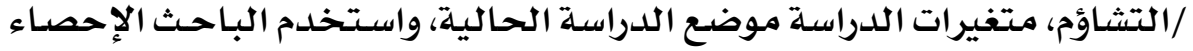

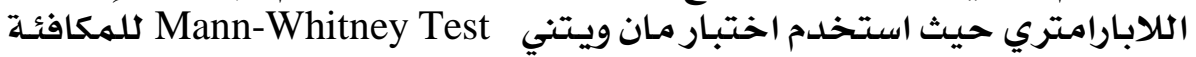

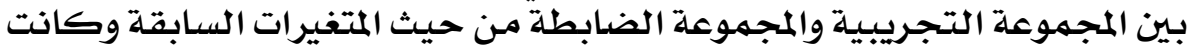

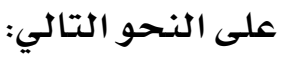

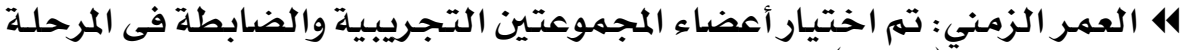

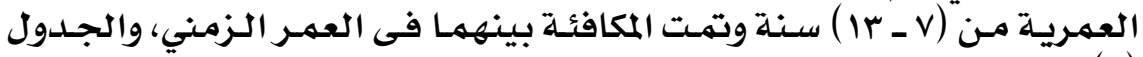

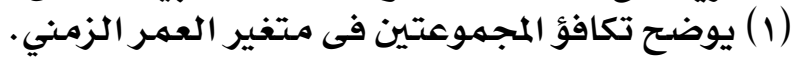

\section{Y Y 9}




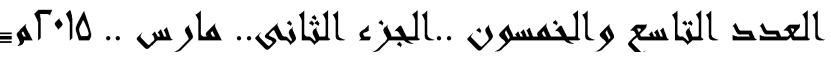

جدول (1 ) دلالة الفروق بين متوسطي رتب درجات أفراد المجموعتين التجريبية والضابطة فى العمر

\begin{tabular}{|c|c|c|c|c|c|c|c|c|}
\hline مستوى & U & مجموع & متوسط الرتب & الانحيارى & المتوسطي & ن ن & المجموعة البيان & المتغير \\
\hline \multirow{2}{*}{ غير دالة } & \multirow{2}{*}{$r . .}$. & $\varepsilon 1 . \cdots$ & $7 . \wedge r$ & Y. $\cdot V$ & 1.0. & 7 & التحريبية & \multirow{2}{*}{ الزمني } \\
\hline & & $0 \ldots . .$. & V.1ई & r.OV & $1+.\{Y$ & $v$ & الضابطة & \\
\hline
\end{tabular}

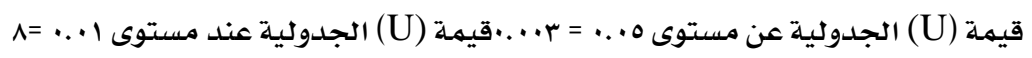

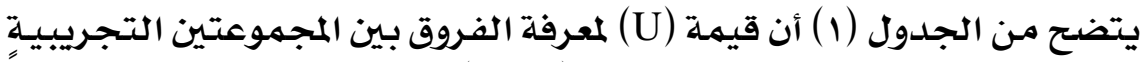

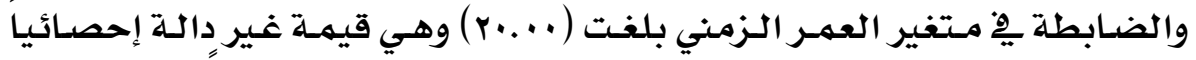

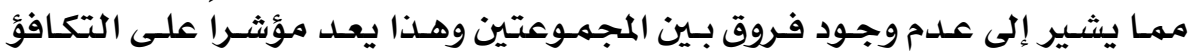

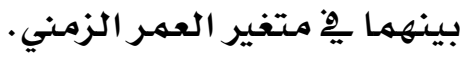

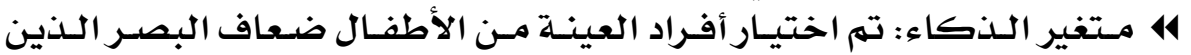

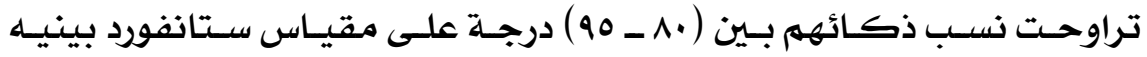

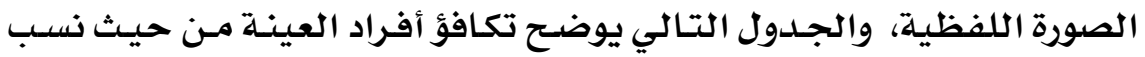

$$
\text { الذكاء. }
$$

\begin{tabular}{|c|c|c|c|c|c|c|}
\hline لدلالة & $\bar{U}$ & محمدء الرت & متوسط الدت & $\therefore$ & בمa & |تفي \\
\hline \multirow{2}{*}{ عاه. • غير دالة } & \multirow{2}{*}{17.0.} & rv.o. & 7. Yo & 7 & التحربــة & \multirow{2}{*}{ الذكاء } \\
\hline & & or.o. & $V . T \varepsilon$ & $v$ & الضابطة & \\
\hline
\end{tabular}

جدول ( ץ ) دلالة الفروق بين متوسطي رتب درجات أفراد المجمومتين التجريبية والضابطة على متغير

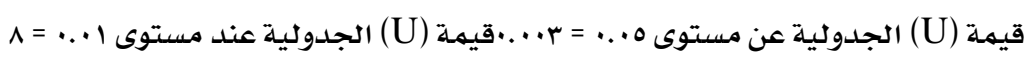

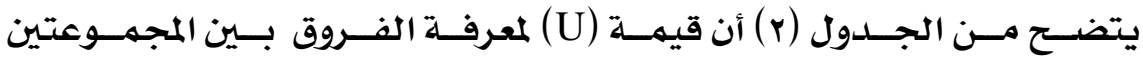

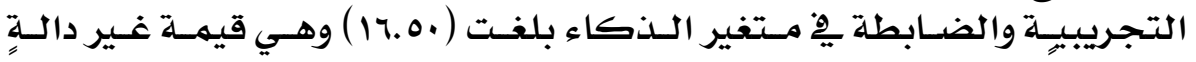

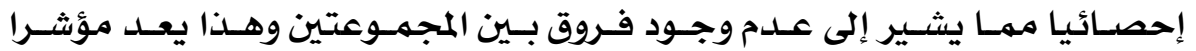

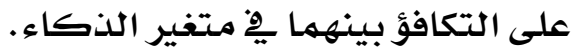

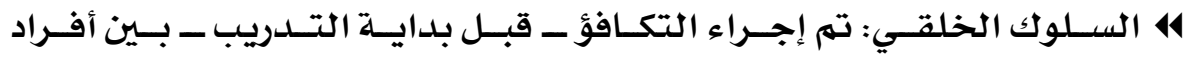

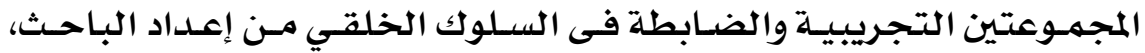

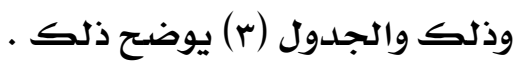

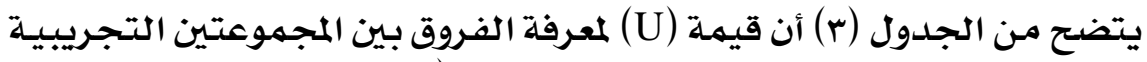

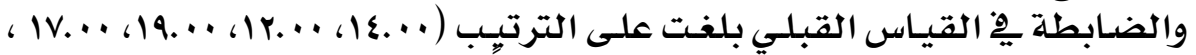

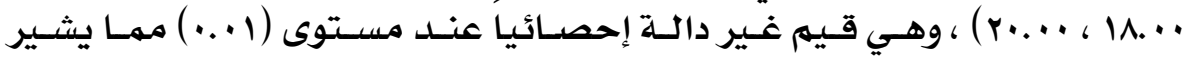

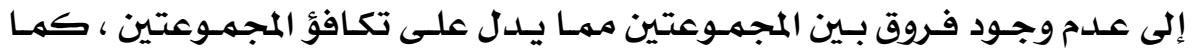

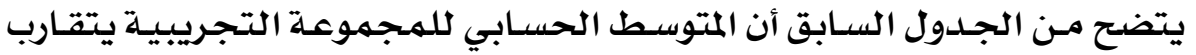

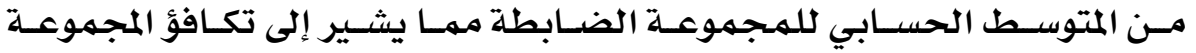
التجريبية والمجمهوعة المتوس الضـابطة.

\section{Yr.}


العكد التزاسع والخمسول ..الجزء الثخانىى.. هارس ..

جدول (r) دلالة الفروق بين متوسطي رتب درجات أفراد المجمومتين التجريبية والضابطة فى القياس

\begin{tabular}{|c|c|c|c|c|c|c|c|c|}
\hline \multicolumn{9}{|c|}{ القبلي للسلوك الخلق } \\
\hline مستوى & $\mathrm{U}$ & الانحيـراف & المتوسط & مجموع & متوسط الرتب & العدد & المجموعات & الأبعاد \\
\hline \multirow{2}{*}{$\cdot r \cdot \varepsilon$} & \multirow{2}{*}{$1 \xi \ldots$} & 1.17 & 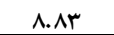 & ro... & $0 . \wedge r$ & 7 & تجريبية & \multirow{2}{*}{ الصدق } \\
\hline & & 1.YV & $9.0 \mathrm{~V}$ & 04... & A... & $\mathrm{V}$ & ضابطة & \\
\hline \multirow{2}{*}{. $.19 r$} & \multirow{2}{*}{ Ir... } & $1 . r 9$ & $1 \cdot . \mu r$ & $01 . .$. & 1.0. & 7 & تجريبية & \multirow{2}{*}{ التعاون } \\
\hline & & $1.0 \mathrm{~V}$ & $9.1 \varepsilon$ & $\{\ldots .$. & $0 . v 1$ & $\mathrm{v}$ & ضابطة & \\
\hline \multirow{2}{*}{$\cdot v v$} & \multirow{2}{*}{$19 .}$. & $1 . Y 7$ & $1 \ldots$. & $\varepsilon \cdots .$. & $7.7 \mathrm{~V}$ & 7 & تجريبية & \multirow{2}{*}{ الصبر } \\
\hline & & $1.9 \mathrm{~V}$ & $1 \cdot . \mathrm{YA}$ & $01 . .$. & V.rq & $V$ & ضابطة & \\
\hline \multirow{2}{*}{$.0 \leqslant 0$} & \multirow{2}{*}{ IV... } & $1 . . r$ & 1.77 & $r \wedge . .$. & 7. & 7 & تجريبية & \multirow[t]{2}{*}{ الأمانة } \\
\hline & & 1.17 & $9.1 \varepsilon$ & or.... & V.ov & $\mathrm{v}$ & ضابطة & \\
\hline \multirow{2}{*}{.77} & \multirow{2}{*}{$1 \wedge . \cdots$} & $1 . r 1$ & $1 . .74$ & $\{0 . .$. & T. & 1 & تجريبية & \multirow[t]{2}{*}{ الإيثار } \\
\hline & & $1 . r \Lambda$ & $1 \cdot \mathrm{rA}$ & $\{7 . .$. & $7.0 \mathrm{~V}$ & $v$ & ضابطة & \\
\hline \multirow{2}{*}{. .110} & \multirow{2}{*}{$r \ldots .}$. & $r .01$ & $\{\wedge .0$. & $\varepsilon r . .$. & V.IV & 7 & تجريبية & \multirow{2}{*}{ الدلدرجة } \\
\hline & & r.01 & $\{\Lambda . \leqslant r$ & $\{\wedge . .$. & 7.14 & $\mathrm{v}$ & ضابطة & \\
\hline
\end{tabular}

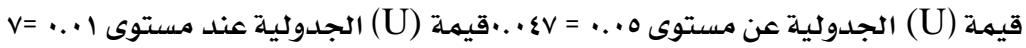

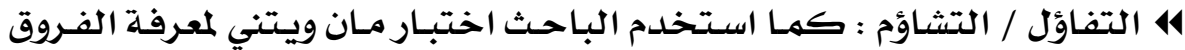

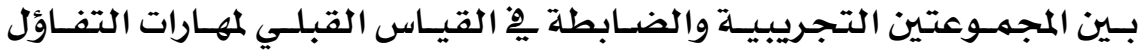

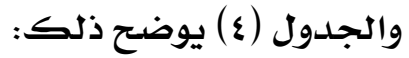

جدول (ع ) دلالة الفروق بين متوسطي رتب درجات المجمومتين التجريبية والضابطة يـ القياس القبلي

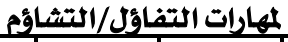

\begin{tabular}{|c|c|c|c|c|c|c|c|c|}
\hline مستوى الدلاكية & $\mathrm{U}$ & الانحراف المعياري & المتوسط & مجرتموع & متوسط الرتب & ن & المجموعة البيان & الأبعاد \\
\hline \multirow[b]{2}{*}{ 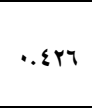 } & \multirow[b]{2}{*}{10.0} & $1 . \mathrm{rV}$ & 1. 0. & m.. 0. & $7 . \cdot 1$ & 7 & التجريبية & \multirow{2}{*}{ الإقبال على الإقبال على الحياة/ } \\
\hline & & Y.YY & Q. ¿r & $0 \leqslant .0$. & V.Vq & $\checkmark$ & الضابطة & \\
\hline \multirow{2}{*}{$.7 \leqslant V$} & \multirow{2}{*}{$1 \wedge . \cdots$} &. .117 & V.77 & $\varepsilon 0 . \cdots$ & V.o. & 7 & التجريبية & \multirow{2}{*}{ الثقة بالنفس/ علثـالنفس } \\
\hline & & $.9 \vee 0$ & V. $\{Y$ & $\varepsilon 7 . \cdots$ & $7.0 \mathrm{~V}$ & $\checkmark$ & الضـابطة & \\
\hline \multirow{2}{*}{$\cdot v \cdot 1$} & \multirow{2}{*}{ 11.0. } & . vor & A. 17 & $\leqslant \leqslant .0$. & $V . 乏 Y$ & 7 & التحريبية & \multirow{2}{*}{ الشعور بالنجاح/ الشعل } \\
\hline & &. .117 & A. .. & $\varepsilon 7.0$. & $7.7 \varepsilon$ & V & الضـابطة & \\
\hline \multirow[b]{2}{*}{$\because 9 \varepsilon$. } & \multirow[b]{2}{*}{$r \cdot .0}$. & . Vor & 1.17 & $\$ 1.0$. & 7.94 & 7 & التججريبية & \multirow{2}{*}{ اللمستقبل/الإيجابية النظرة } \\
\hline & & 1.ro & A. $1 \varepsilon$ & $\leqslant 9.0$. & $v_{\cdot} \cdot v$ & $\checkmark$ & الضابطة & \\
\hline \multirow[b]{2}{*}{$\cdot \wedge \wedge \varepsilon$} & \multirow[b]{2}{*}{$r . .}$. & 1.01 & A.r & $\varepsilon 1 . \ldots$ & 7. ז & 7 & التجريـيـة & \multirow{2}{*}{ التحدي والمثابرة } \\
\hline & & $1 . V Y$ & A. $\leqslant Y$ & $0 . .$. & V.1E & V & الضابطة & \\
\hline \multirow{2}{*}{$\because 1919$} & \multirow{2}{*}{ 11.0. } & r.یT & $\varepsilon \cdot . \wedge r$ & ra.o. & 7.01 & 7 & التجريبية & \multirow{2}{*}{ الدرجـة الكلية } \\
\hline & & r.o\& & $\sum 1 . Y \wedge$ & 01.0. & V.ru & V & الضـابطة & \\
\hline
\end{tabular}

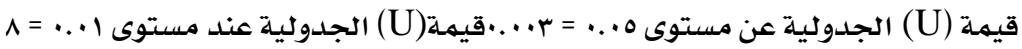

يتضح من الجدول (ع ) أن قيمـة (U) لمعرفة الفروق بين المجموعتين التجريبيـة

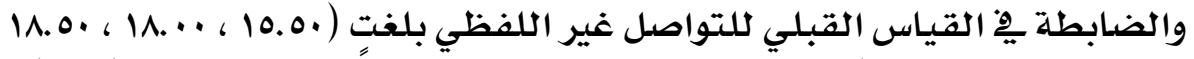

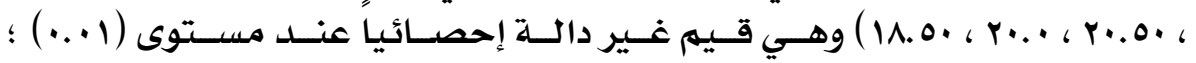

\section{Y T}


العكد التزاسع والخمسول ..الجزء الثخانىى.. هارس ..

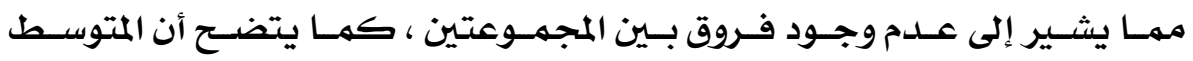

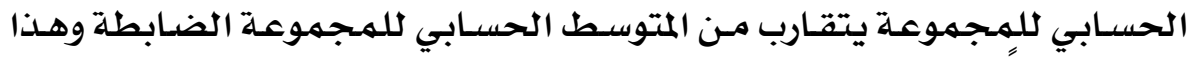

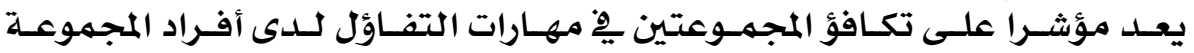

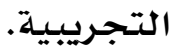

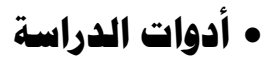

تمثلت أدوات الدراسـة في الأدوات التالية:

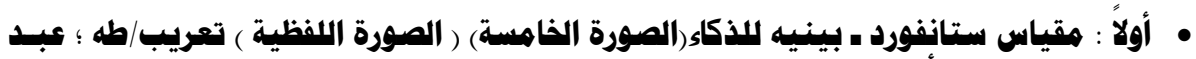

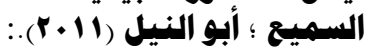

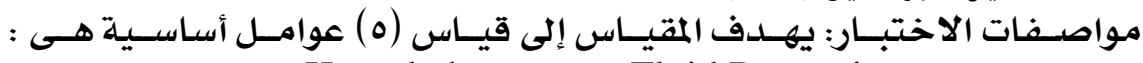

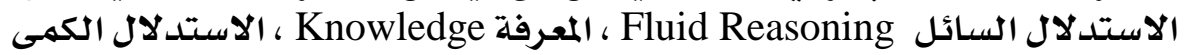

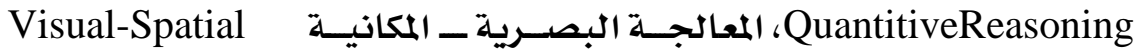

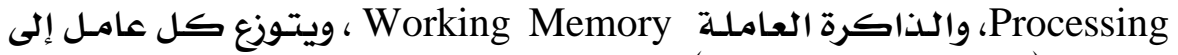

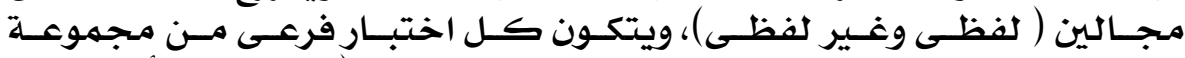

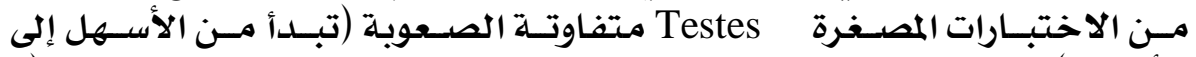

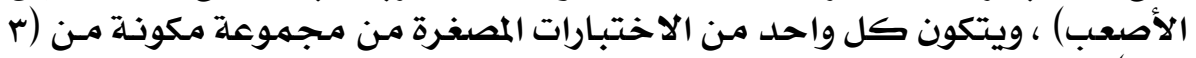

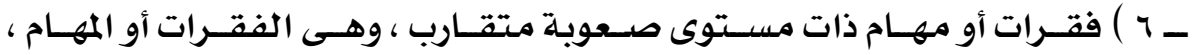

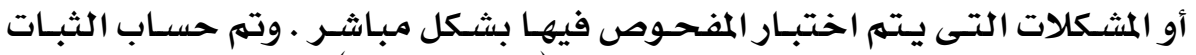

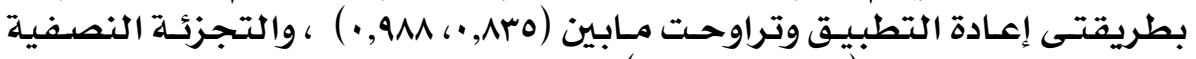

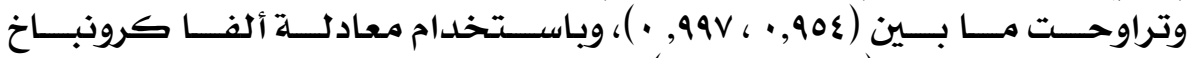

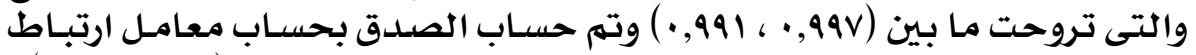

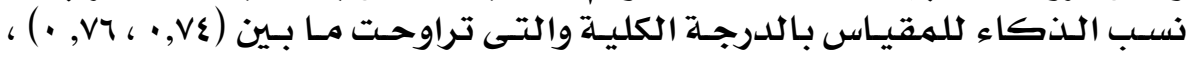

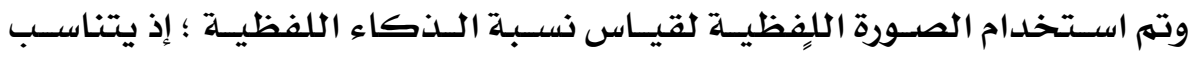

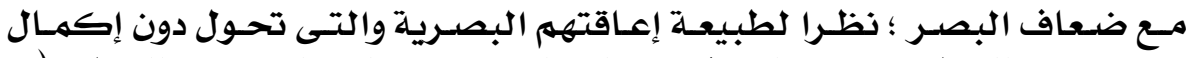

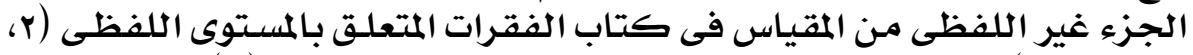

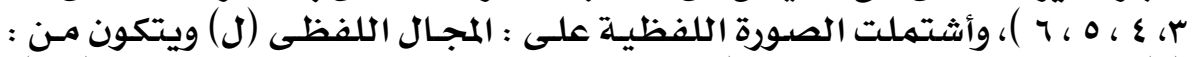

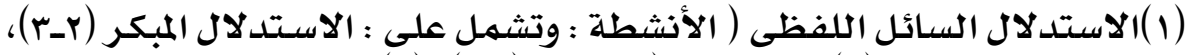

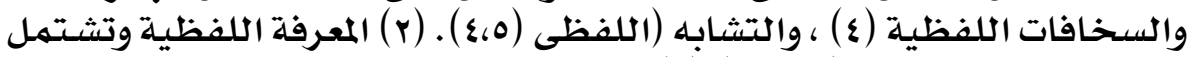

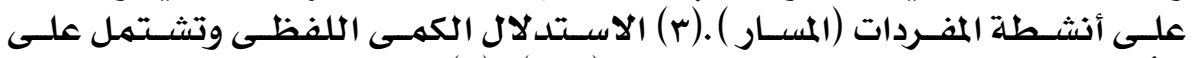

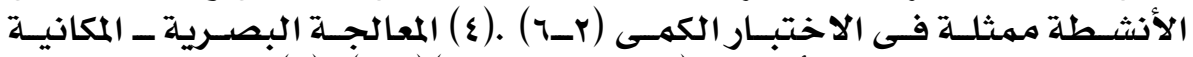

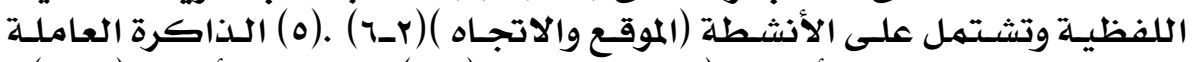

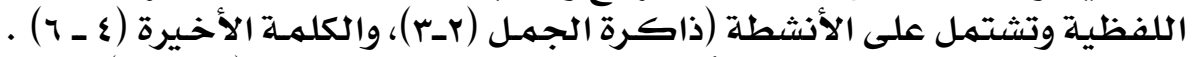

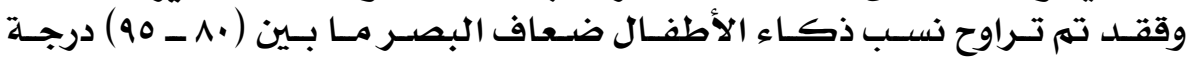

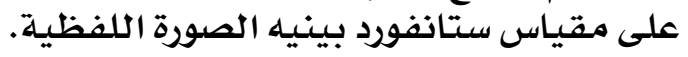

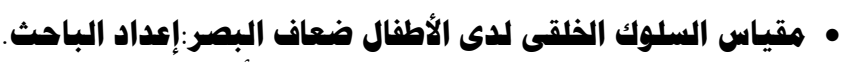

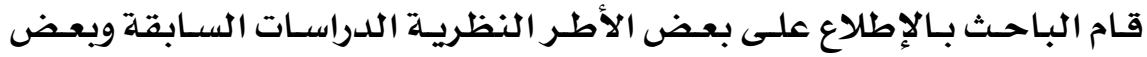

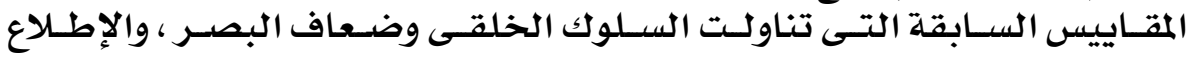

\section{YYY}




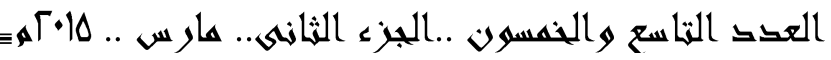

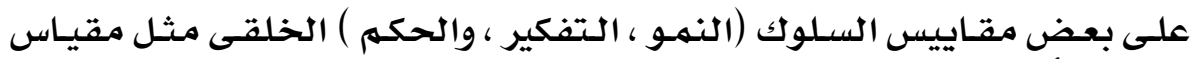

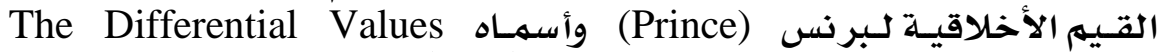
لInventory

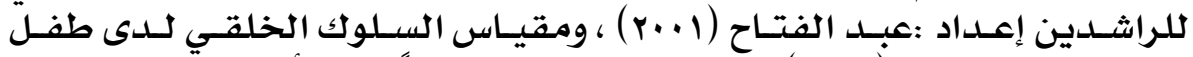

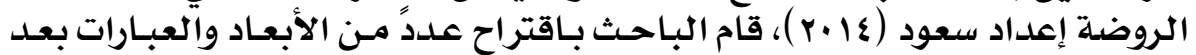

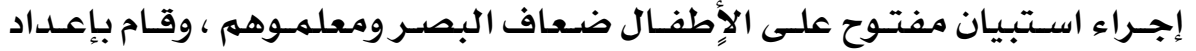

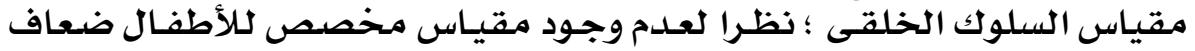

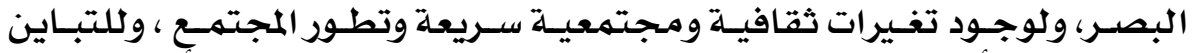

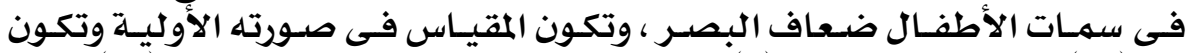

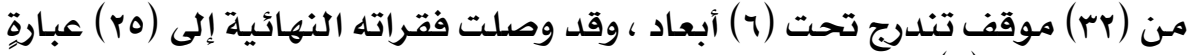

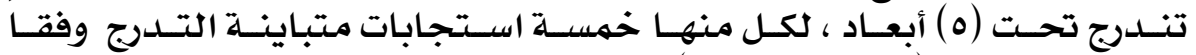

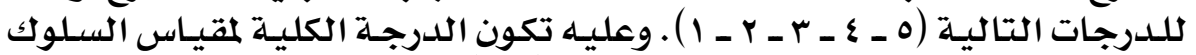

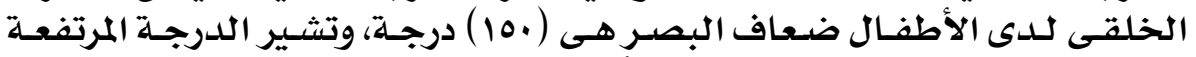

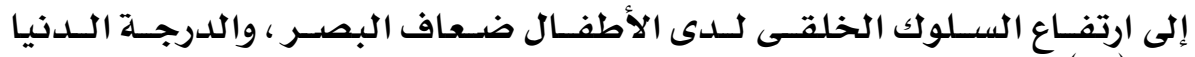

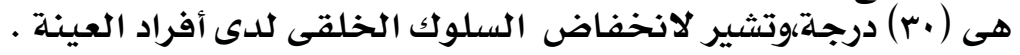

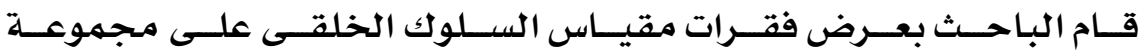

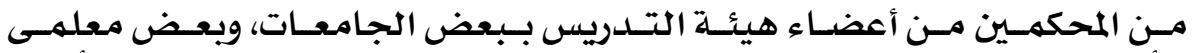

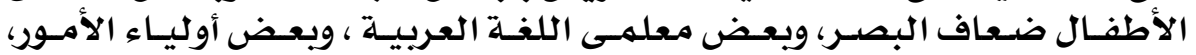

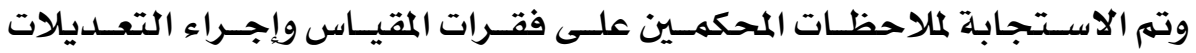

وحذف بعضها.

• طريقة التطبيق

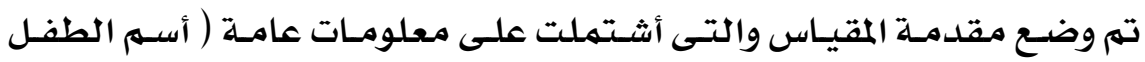

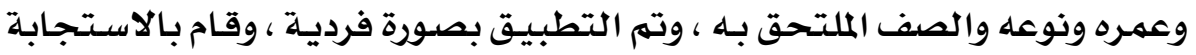

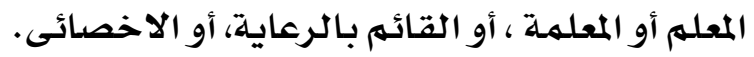

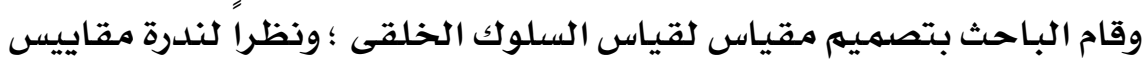

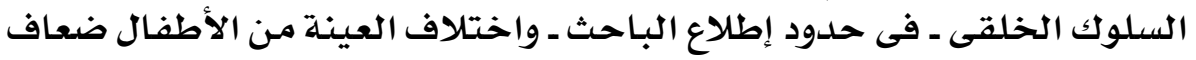

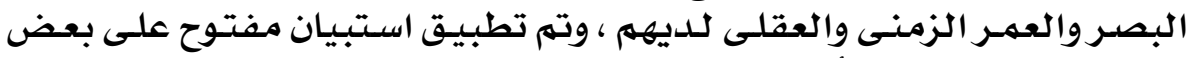

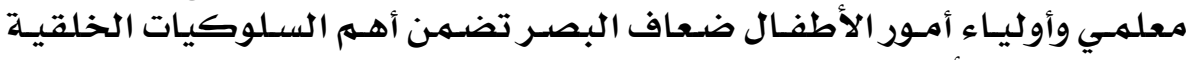
المنتشرة لدى الأطفال ضعاف أمسور الأفال البصر.

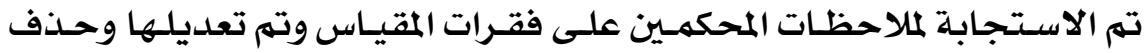
بعضها.

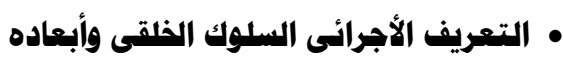

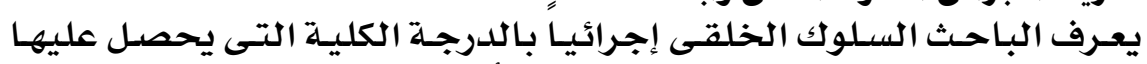

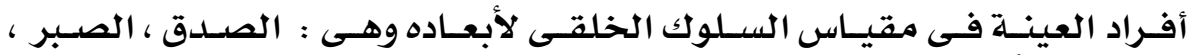
التعاون ، الأمانة، والإيثار.

\section{YMY}


العكد التزاسع والخمسول ..الجزء الثخانىى.. هارس ..

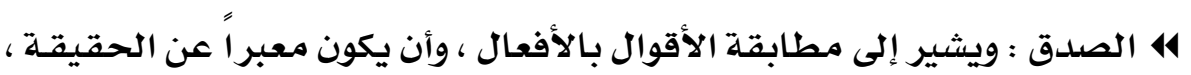

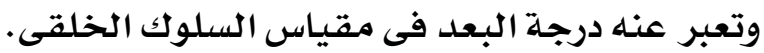

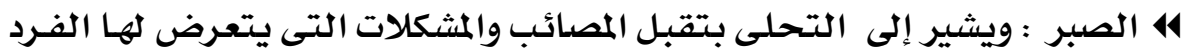

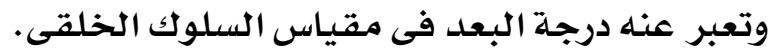

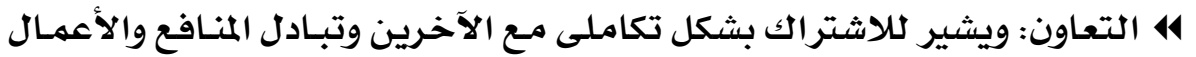

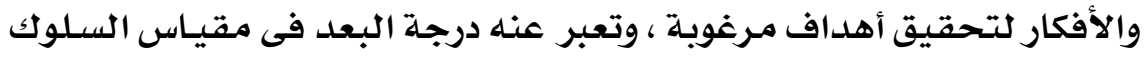
الخلقى.

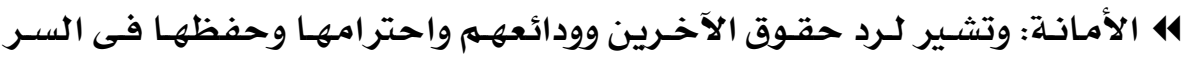

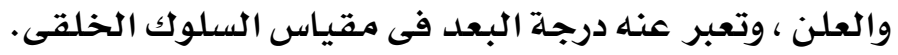

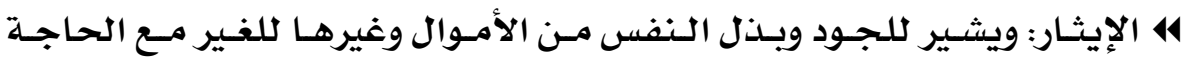

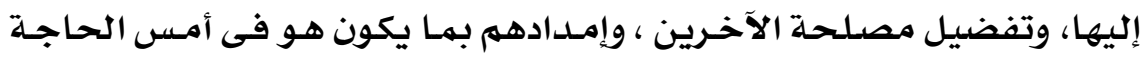

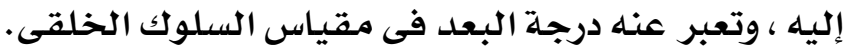

\section{• الخصائص السيكوهترية:}

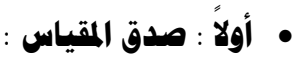

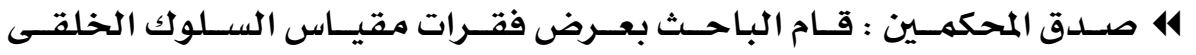

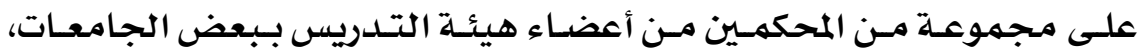

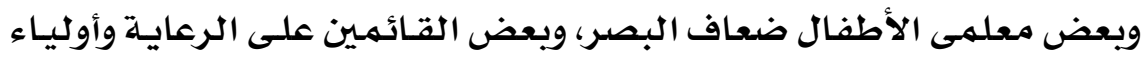

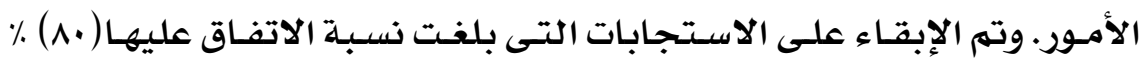

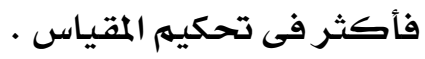

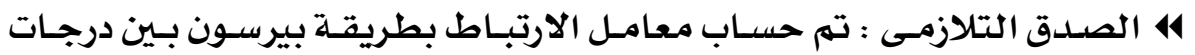

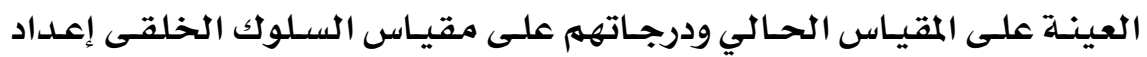

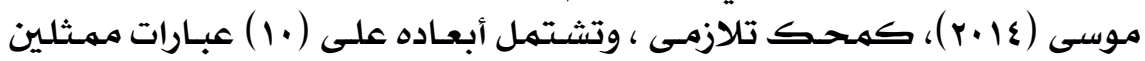

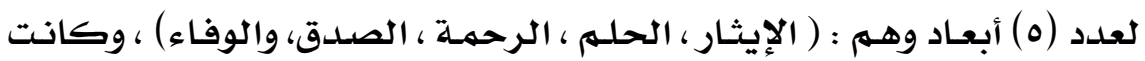

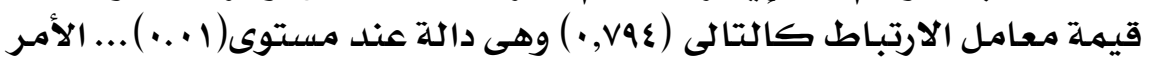

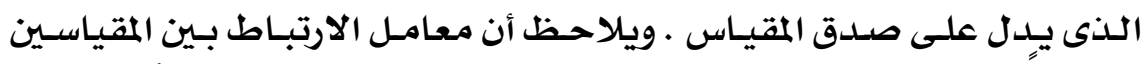

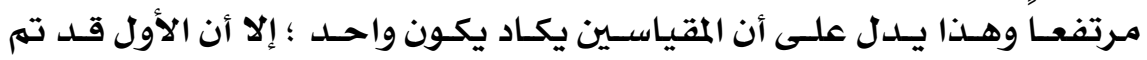

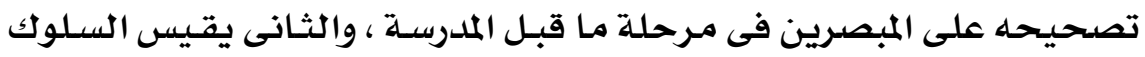

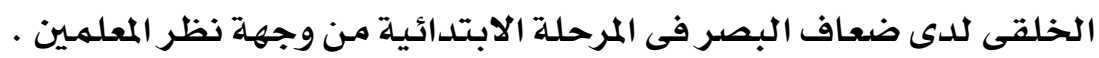

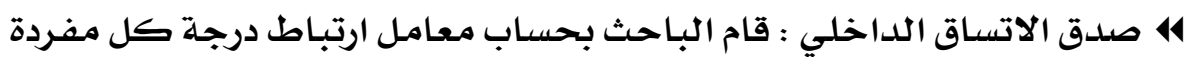

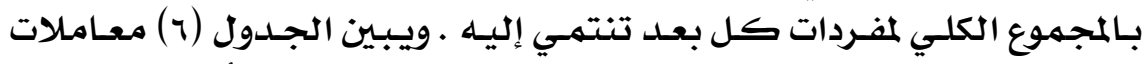

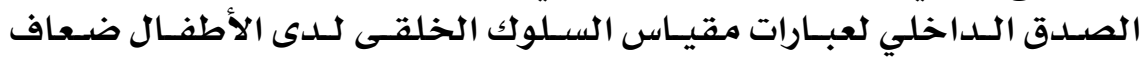

\section{YY\&}




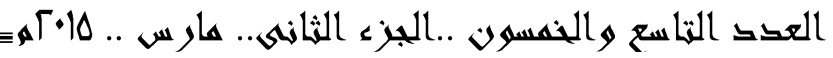

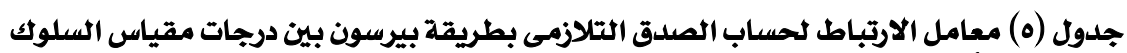

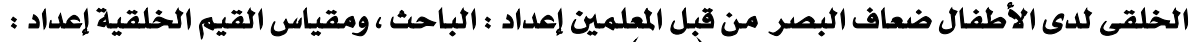

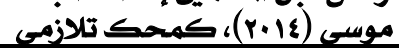

\begin{tabular}{|c|c|c|c|c|c|}
\hline \multicolumn{5}{|c|}{ معاملات الارتباط } & البعد \\
\hline الوفاء & الصدق & الرحمة & الحله & الإيثار & \\
\hline$\therefore V V r$ & - & .770 &. .179 &.$v \varepsilon r$ & الصدق \\
\hline .0779 & .707 & $.0 \mathrm{VA}$ & . ntro & . & التعاون \\
\hline$\cdot . \wedge \leqslant r$ & $\therefore \mathrm{VVq}$ & . &. Vro & $\cdot . \varepsilon r \xi$ & الصبر \\
\hline$. V \leqslant 7$ & $\cdot . \Lambda \cdot Y$ &..$\wedge \mathrm{VI}$ &.. $\mathrm{V} 4 \mathrm{~A}$ &.$V I r$ & الأمـانة \\
\hline. .741 &. $\mathrm{VVT}$ &. Vos &. .110 & $.0 \leqslant 7$ & الإيثار \\
\hline. .107 & $\because$ Vos & ..$\wedge \mathrm{rr}$ &. .170 & $\cdot . \leqslant T V$ & الدرجهة الكلية \\
\hline
\end{tabular}

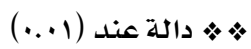

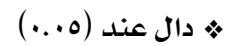

جلدول ( ) معاملات الارتباط بين درجة كل مفردة والدرجة الكلية للبعد التي تنمي إليه فى مقياس

\begin{tabular}{|c|c|c|c|c|c|c|c|}
\hline معاملات & $\hat{r}$ & معاملات & $\hat{r}$ & معاملات & $\hat{\rho}$ & معاملات & r \\
\hline قيمة ر & $\hat{\beta}$ & قيمة ر & $\hat{\rho}$ & قيمة ر & م & قيمة ر & م \\
\hline$* * . .7 \varepsilon$ & ri & $* * \cdot$. vo & rI &. $.1 r$ & 11 & $* * \cdot \vee \vee q$ & 1 \\
\hline$* * . v r$ & rr & ז. & rr & $* \& \cdot \leqslant 0$ & ir & $\$ * \cdot .7 \varepsilon$ & r \\
\hline$+\% \cdot . T r$ & r & 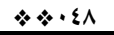 & $r$ & $\$ \% \cdot .0 \mathrm{~V}$ & ir & $* * . \leqslant V$ & $r$ \\
\hline. .11 & $r \varepsilon$ & $* * 7$. & $r \varepsilon$ & $* * \cdot \wedge$. & $1 \varepsilon$ &. .1 . & $\varepsilon$ \\
\hline$* * .7 \varepsilon$ & ro &. .11 & ro & * *..TV & 10 & * * \% & 0 \\
\hline. .14 & דו & 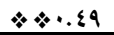 & rq & 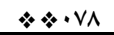 & 17 & $\% * . .4 q$ & 7 \\
\hline$* * 0.0$ & rv & $* * \cdot \pi r$ & rV & $* * \cdot . \wedge 1$ & IV & $* \% \cdot . \Sigma \mathrm{V}$ & $\mathrm{v}$ \\
\hline$\% * .79$ & ru & $\$+.07$ & rA & $* * \cdot V r$ & 11 &. .11 & $\Lambda$ \\
\hline$\% * \cdot v$. & rq &. .1 . & rq & $\$ \% .01$ & 19 & $\$ * .09$ & 9 \\
\hline. .11 & $\varepsilon$. & \&.... & r. & $* * \cdot .71$ & $r$. & *.rr & 1. \\
\hline
\end{tabular}

* \&

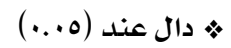

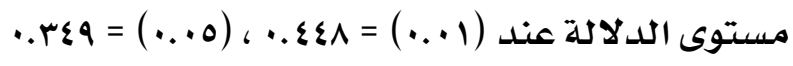

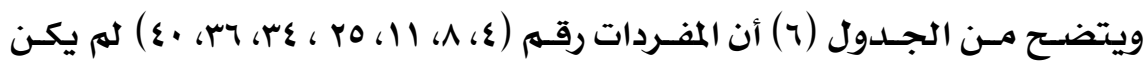

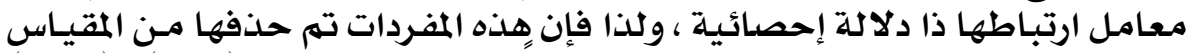

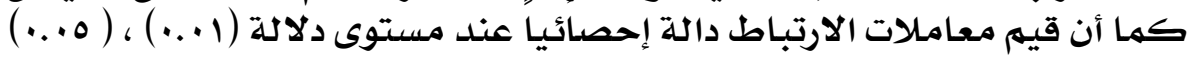

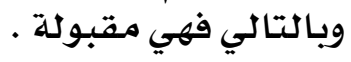

جدول (v) معاملات ارتباط أبعاد مقياس السلوك الخلقي والدرجة الكلية الإنية

\begin{tabular}{|c|c|c|c|c|c|c|}
\hline الدرجة الكلية & الإيثار & الأمـانة & الصبر & التعاون & الصدق & الأبعاد \\
\hline$* * .791$ & **.VRr & **..var & $*$ *. & *.ros & $-\quad-\quad$ & الصدق \\
\hline$* * \cdot V r r$ & $\$+70$ & $* * \pi 1$ & $*$ *. $\leqslant \leqslant Y$ & -- & & التعاون \\
\hline$\& *$ *.v70 & $\& * \cdot \mathrm{TV}$ & \& *.or. & $-\quad-\quad-$ & & & الصبر \\
\hline$* * .791$ & $* * \cdot v r r$ & $-\quad-\quad$ & & & & الأمـانة \\
\hline$\$ *$ * VY & $-\quad-\quad-$ & & & & & الإيثار \\
\hline--- & & & & & & الدرجة الكلية \\
\hline
\end{tabular}

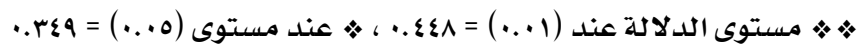

\section{rro}




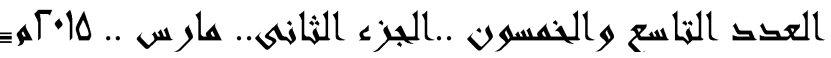

ويتضـح مــن الجـدول (V) أرتبـاط أبعـاد مقيـاس السـلوك الخلقـى بـالدرجـة الكلية بلدرجة دالة إحصائية.

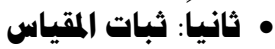

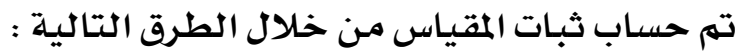

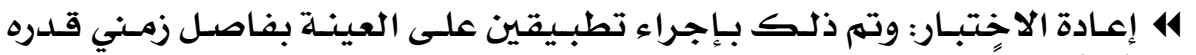

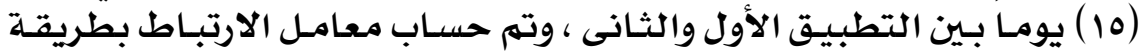

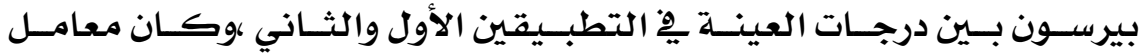

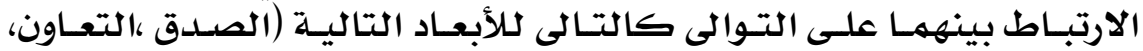

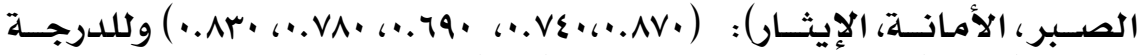

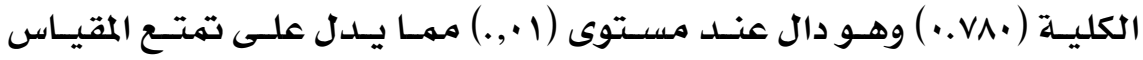
بالثبات.

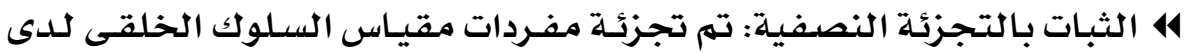

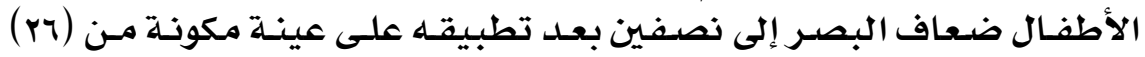

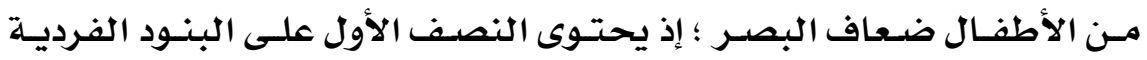

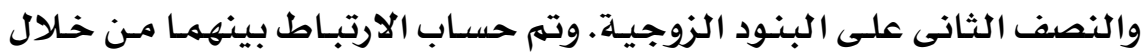

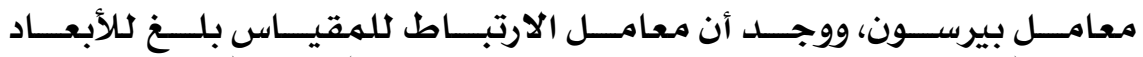

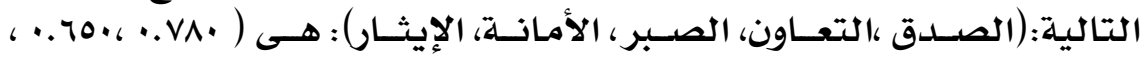

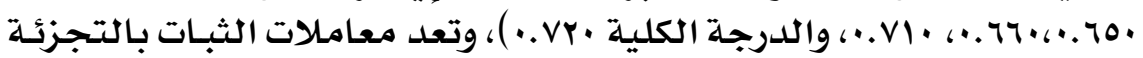

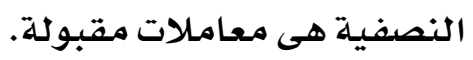

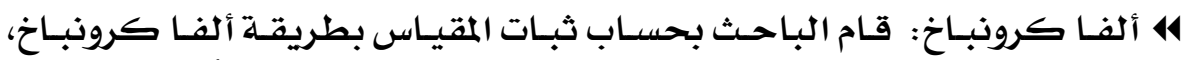

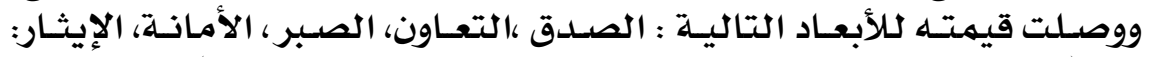

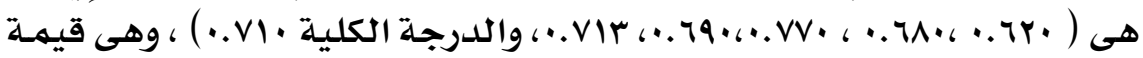

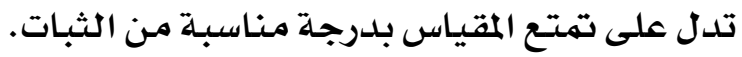

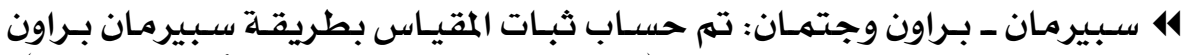

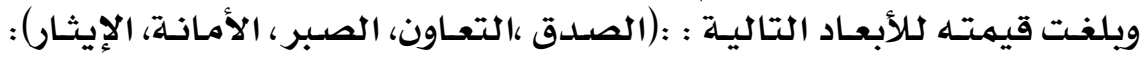

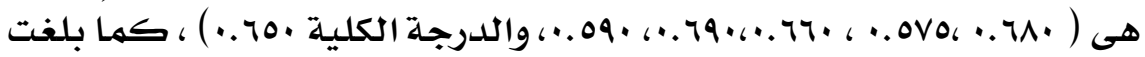

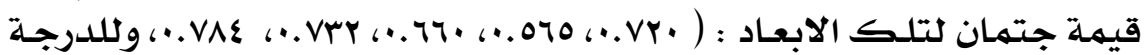

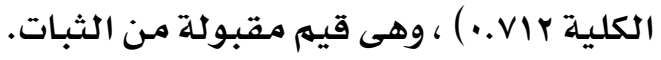

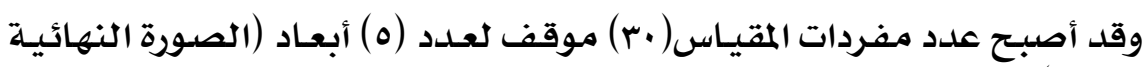
كلمقياس).

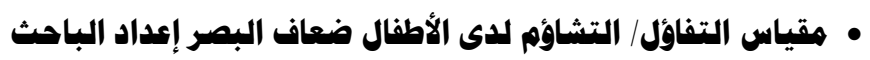

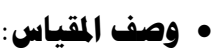

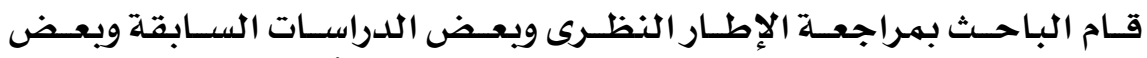

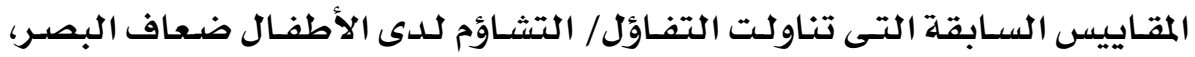

\section{YYY}




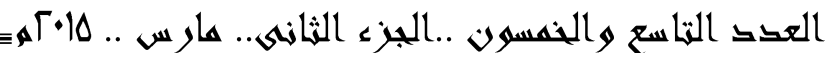

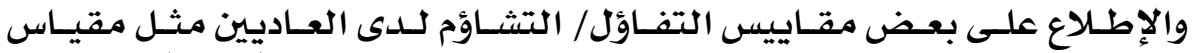

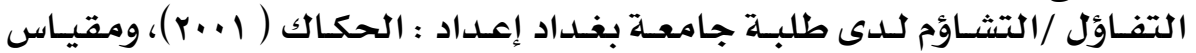

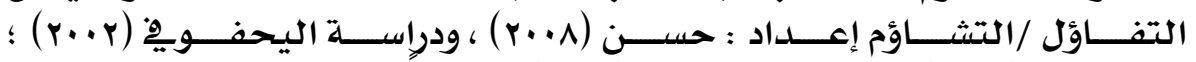

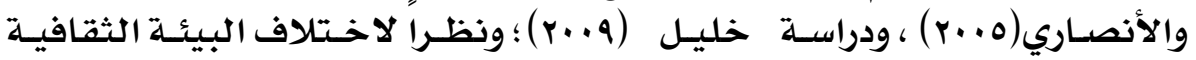

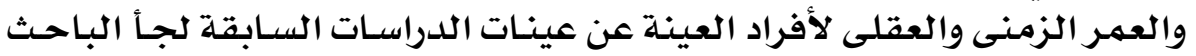

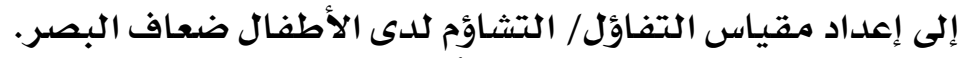

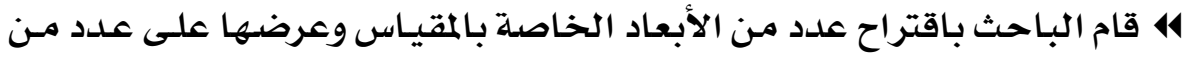

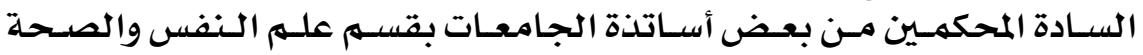

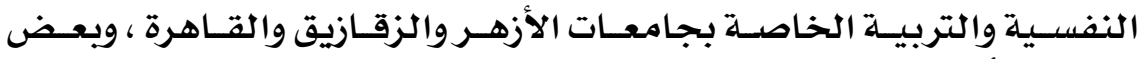

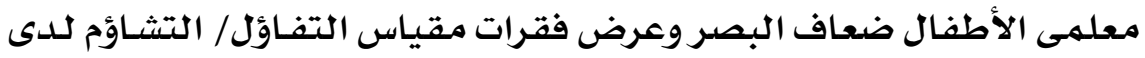

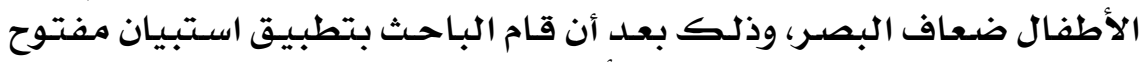

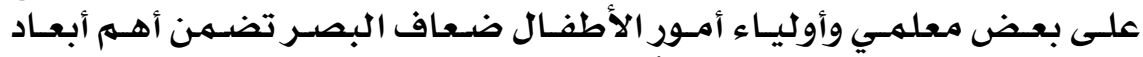

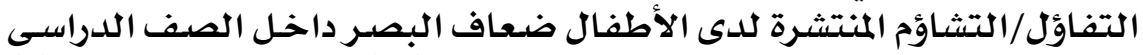

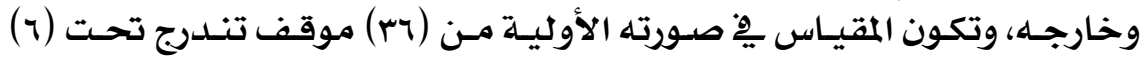

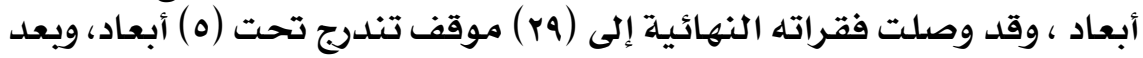

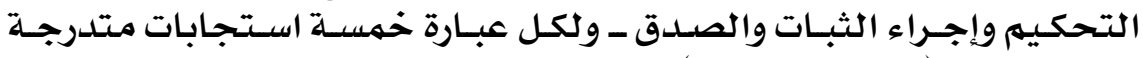

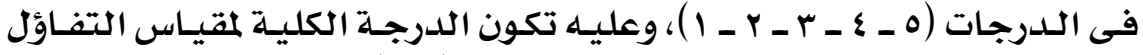

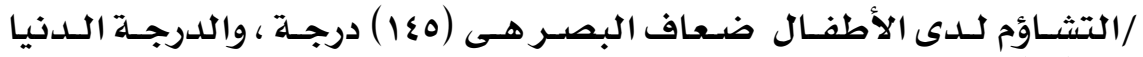

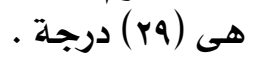

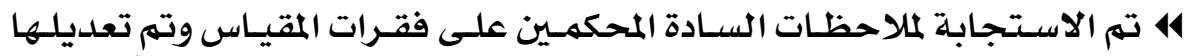

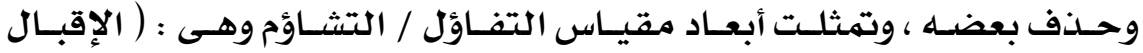

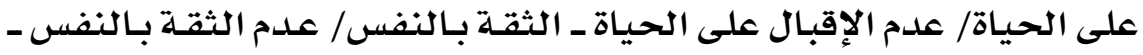

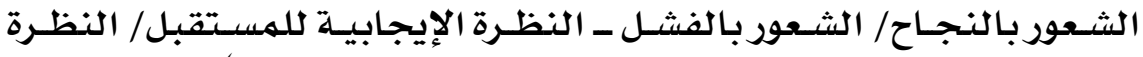

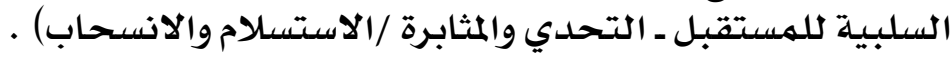

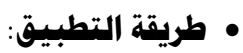

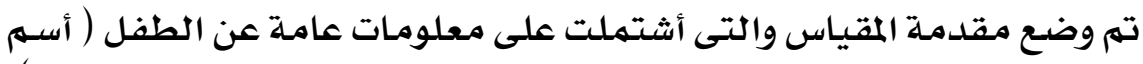

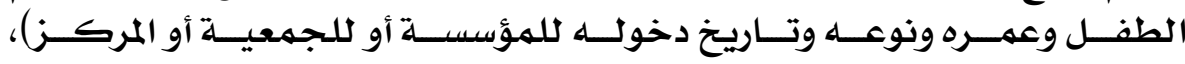

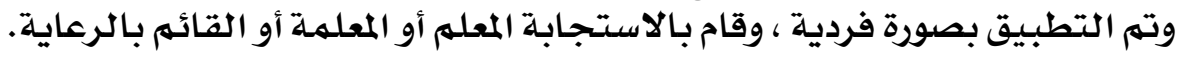

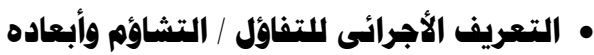

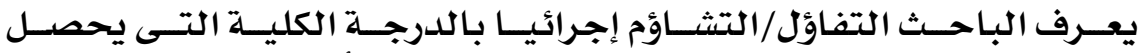

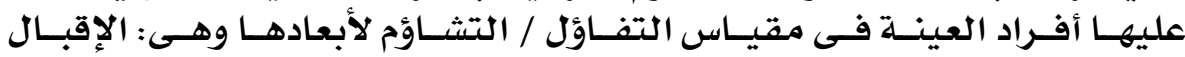

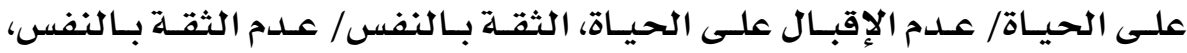

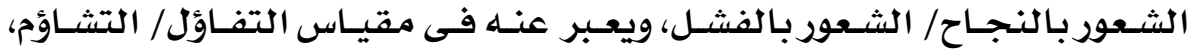

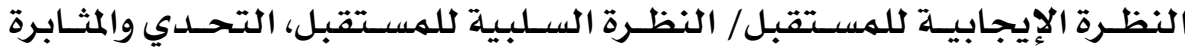

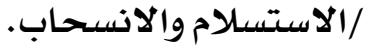

\section{YTV}


العكد التزاسع والخمسول ..الجزء الثخانىى.. هارس ..

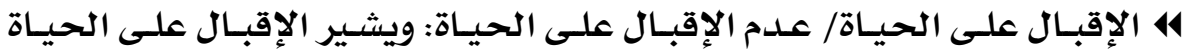

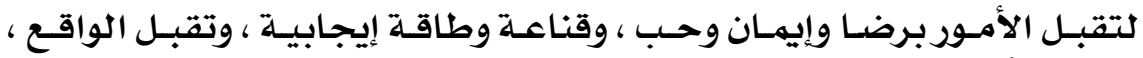

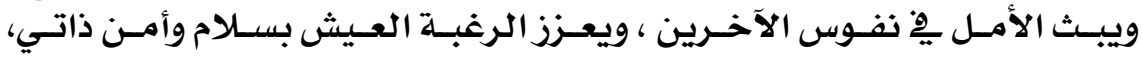

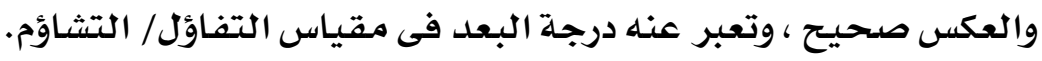

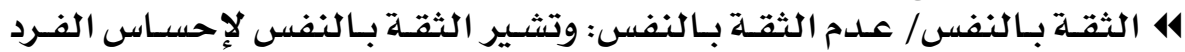

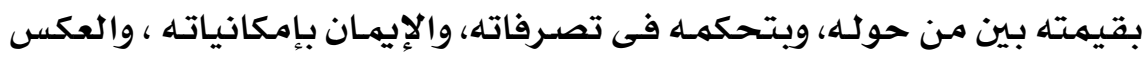

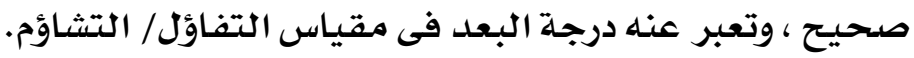

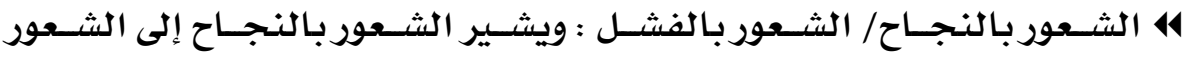

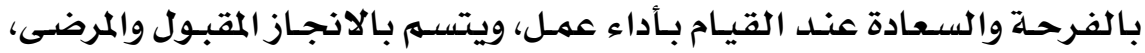

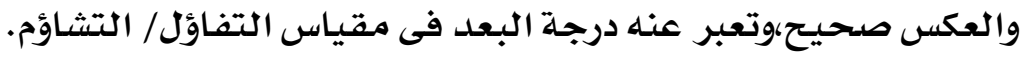

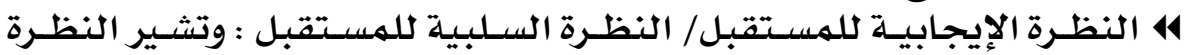

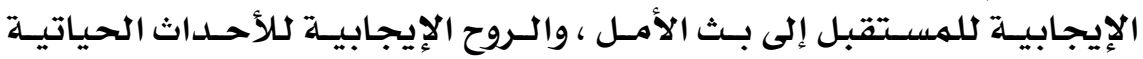

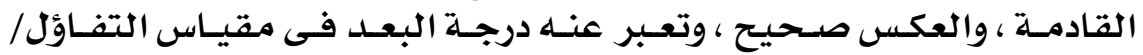

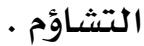

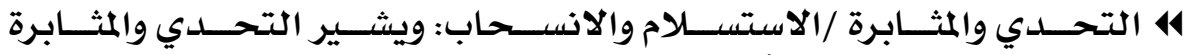

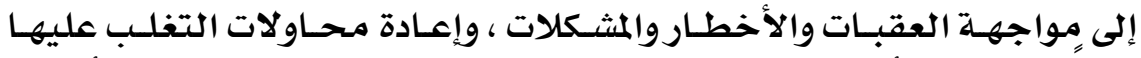

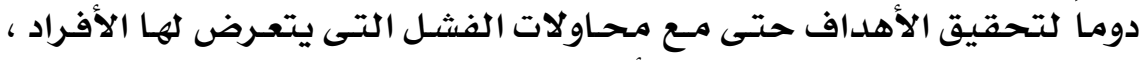

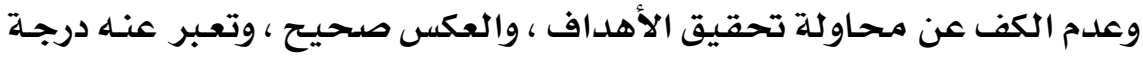

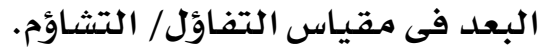

• الخصائص السيكوهترية:

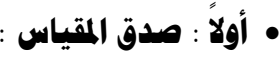

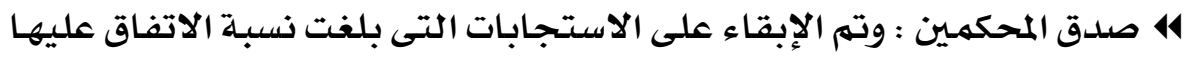

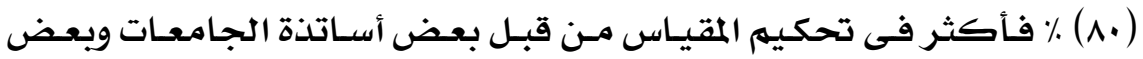

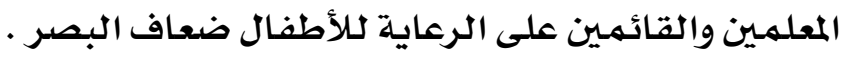

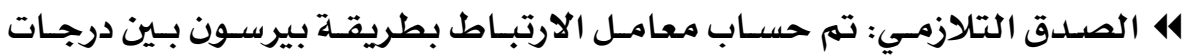

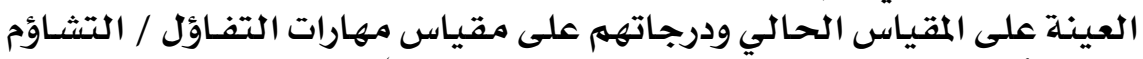

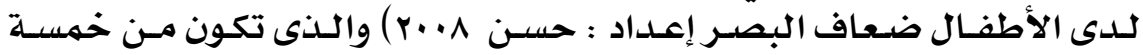

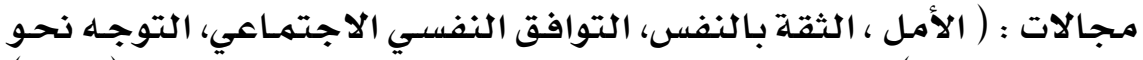

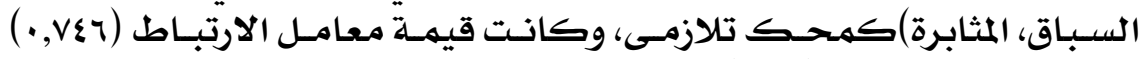

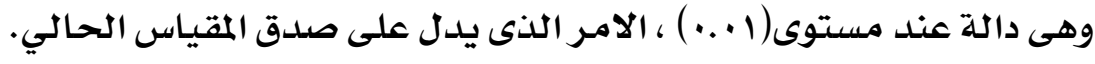

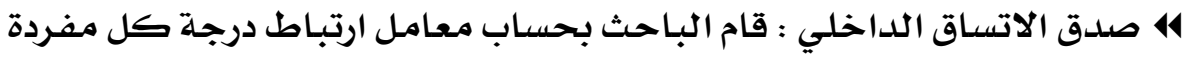

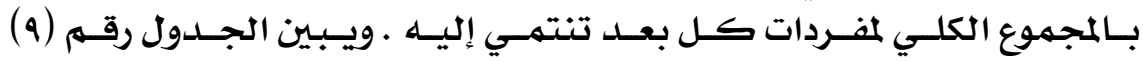

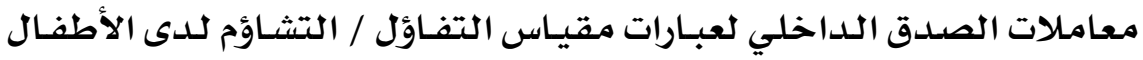

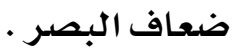

\section{YMA}




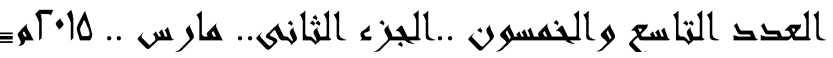

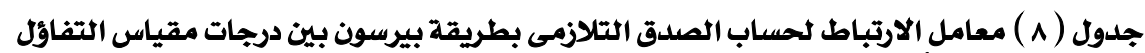

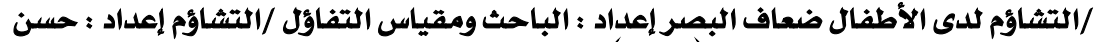

\begin{tabular}{|c|c|c|c|c|c|}
\hline \multicolumn{5}{|c|}{ معاملات الارتباط } & \multirow{2}{*}{ البعد } \\
\hline 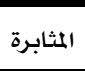 & التوجه نحو & التوافتق النفسى & بالنفة & 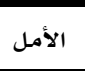 & \\
\hline .07 &. $\mathrm{vv}$. & $\cdot . v 79$ & $\therefore \leqslant 0 \wedge$ &. $.7 r 1$ & الإقبال على الحياة/ عدم الإقبال على \\
\hline. .7 .9 & .079 &. $.50 \Lambda$ & .0 Orr &. $.70 \mathrm{~V}$ & الثقة بالنفس/ عدم الثقة بالنفس \\
\hline ..vY9 &. .209 & $. \quad . \mathrm{VTY}$ &. $.90 \mathrm{~V}$ & $.07 \varepsilon$ & الشعور بالنجاح/ الشعور بالفشل \\
\hline$\therefore \varepsilon \wedge 9$ & .07 & זירו & $. .7 . \varepsilon$ & $.0 \leqslant r$ & النظرة الإيجابية للمستقبلبل/ النظرة \\
\hline. $.0 r y$ & .711 & .07 &.$\cdot \mathrm{v}^{\prime}$ &..$T r r$ & التحدي والمثابرة /الاستسلام \\
\hline rrr &. $.77 \varepsilon$ &. $.7 \mathrm{Tr}$ &. .709 & $r$ & الدرجة الكلية \\
\hline
\end{tabular}

$$
\text { * \& دالة عند (1...) الدرجة الكلية }
$$$$
\text { * * دال عند (ه...) }
$$

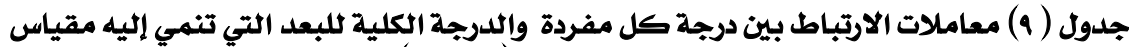

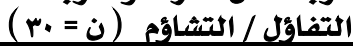

\begin{tabular}{|c|c|c|c|c|c|c|c|}
\hline معاملات & ? & معاملات & $\hat{\imath}$ & معاملات & $\hat{\imath}$ & معاملات & p \\
\hline قيمة & P & قيمة ر & م & قيمة ر & s & قيمة & p \\
\hline$* \% \cdot \pi$ & ri & 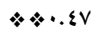 & rI & ..1. & 11 & $* * \cdot v$. & 1 \\
\hline$\$ * 0.07$ & $r Y$ &. .1 . & $r r$ & $* * \cdot$. vo & ir & $* * \cdot r v$ & $r$ \\
\hline$* * \cdot V r$ & $r$ & $\$ 4.07$ & $r$ & $* * . \leqslant r$ & ir & $\therefore .1$. & $r$ \\
\hline 0.9 & $r \varepsilon$ & $\$ \% \cdot 79$ & $r \varepsilon$ &. .11 & $1 \varepsilon$ & $* * .7$ & $\varepsilon$ \\
\hline$* * \cdot 7$ & ro &. $.1 r$ & ro & $\$ * 0.07$ & 10 & $\$ * 0.00$ & 0 \\
\hline$\$ * .01$ & mi & $* \cdot \varepsilon r$ & YT & $* * . \leqslant r$ & 17 &. .11 & 7 \\
\hline .1 . & rv & $\$ 4.09$ & rV & $* * \cdot \vee \varepsilon$ & IV & $* *$ or & $\mathrm{v}$ \\
\hline \multirow[t]{3}{*}{$* * .09$} & rᄉ &. $.1 r$ & YA & .11 & 11 & $.1 r$ & $\wedge$ \\
\hline & & $* \% \cdot v r$ & rq & $\$ * 0.09$ & 19 & 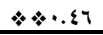 & 9 \\
\hline & &. .11 & $r$. & .11 . & $r$. & $\$ \% \cdot r q$ & 1. \\
\hline
\end{tabular}

$$
\text { \% \& }
$$$$
\text { * * دال عند (.0..) }
$$

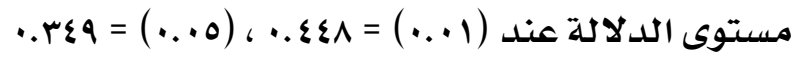

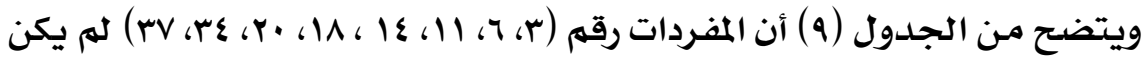

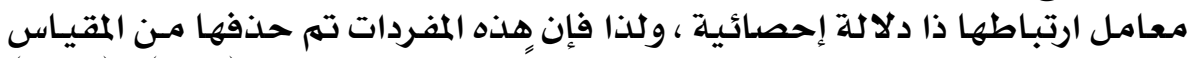

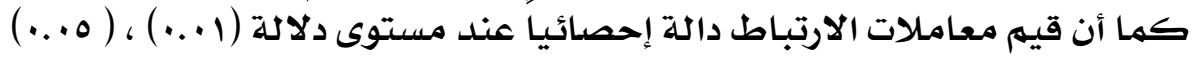

$$
\text { وبالتالي فهي مقبولة أنيم معامالات الان }
$$

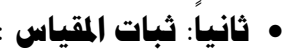

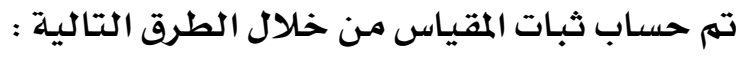

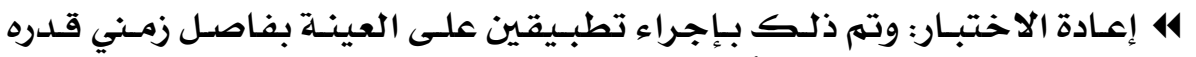

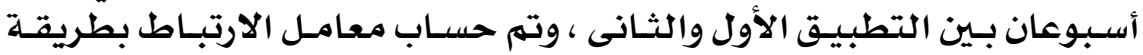

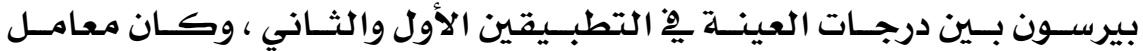

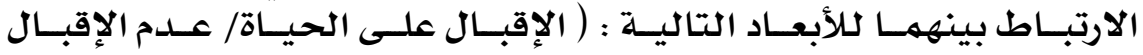

\section{rrq}




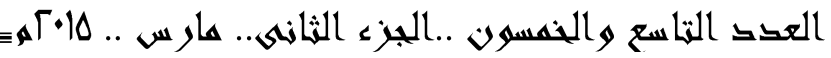

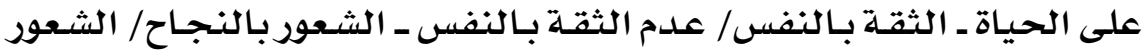

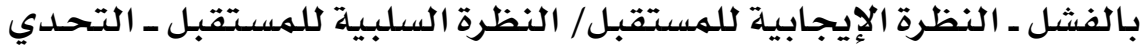

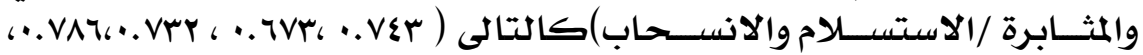

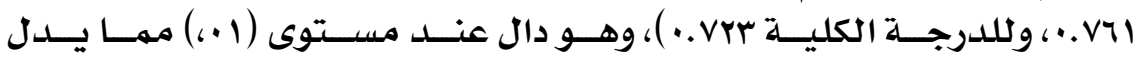

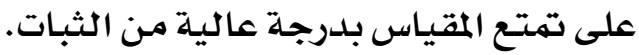

جدول ( ـ ) معاملات ارتباط أبعاد مقياس التفاؤل / التشاؤم والدرجة الكلية

\begin{tabular}{|c|c|c|c|c|c|c|}
\hline الدلية & الإيثار & الأمانة & الصبر & التعاون & الصدق & الأبعاد \\
\hline$* * .791$ & $* * \cdot V Y r$ & $* * \cdot$ var & $* . \varepsilon 1$. & $\$ \cdot$ ros & -- & الإقبال على الحيال على الحياة عدم \\
\hline$* \% \cdot V Y Y Y$ & $\$ \% \cdot 70$ & $* * \cdots, \pi 1$. & $* \cdot . \leqslant \leqslant r$ & --- & & الثقة بالنفس/ عدم الثقة \\
\hline$* * \cdot \cdot v 70$ & $* * \cdot T V$ & $\$ *$. or. & --- & & & الشعور بالنشجاح/ الشعور \\
\hline$* * \cdot .791$ & $* * \cdot v r r$ & $-\quad-$ & & & & اللمستقبل الإيجابية النظرة \\
\hline$* * \cdot V r \varepsilon$ & --- & & & & & /الاستسلامي والانسخحاب \\
\hline-- & & & & & & الدرجة الكلية \\
\hline
\end{tabular}

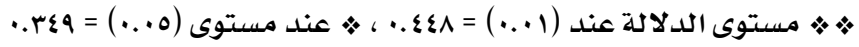

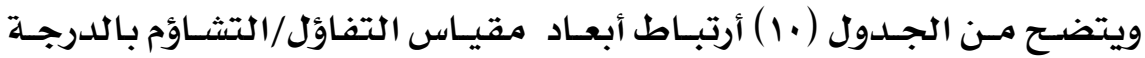
الكلية بلدرجة دالة إحصائية الجدائة

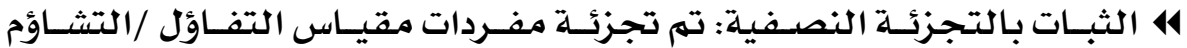

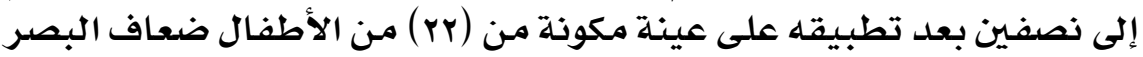

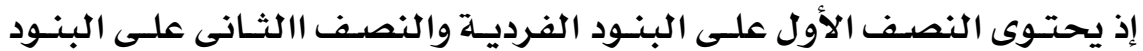

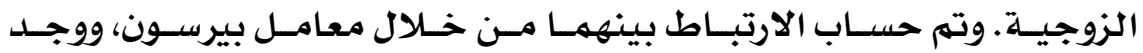

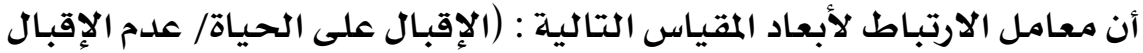

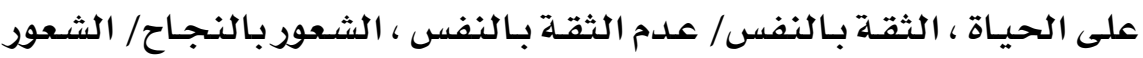

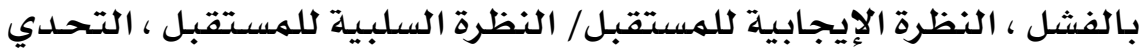

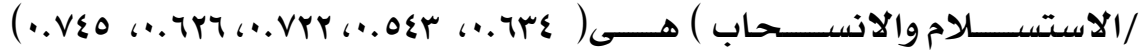

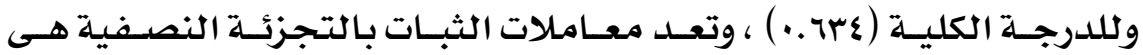
معاملات مقبولة.

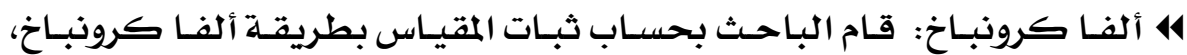

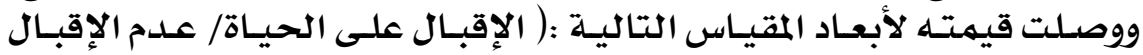

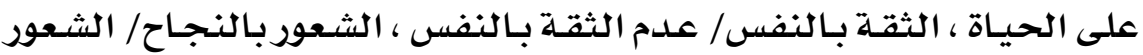

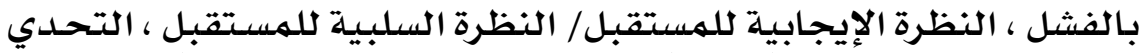

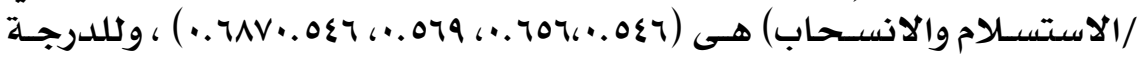
الكلية ( اYT. . ) وهى قيمـة تدل على تمتع المقياس بلدرجة مناسبة من الثبات.

\section{Y\&.}


العكد التزاسع والخمسول ..الجزء الثخانىى.. هارس ..

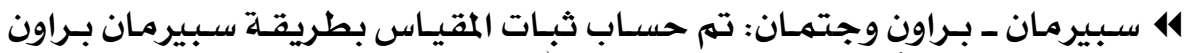

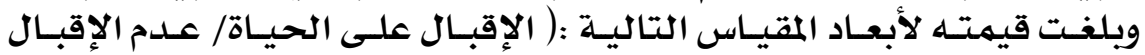

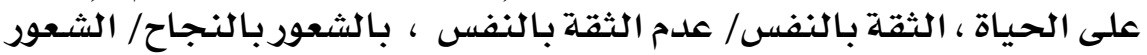

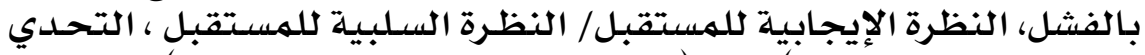

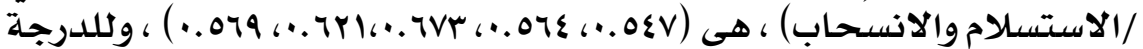

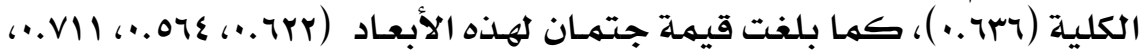

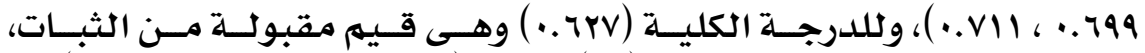

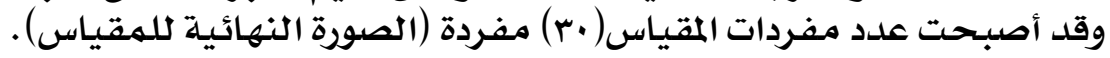
طريقة التطبيق: تم التطبيق بصورة فردية، وقام بالاستجابة القـائم بالرعايـة

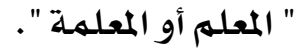

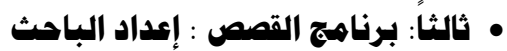

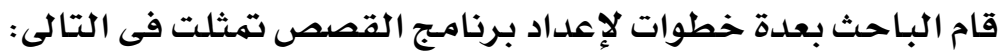

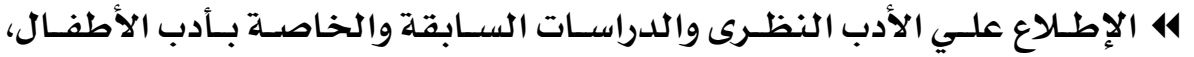

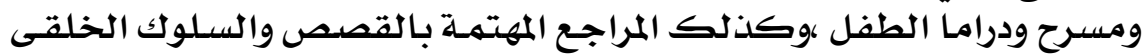

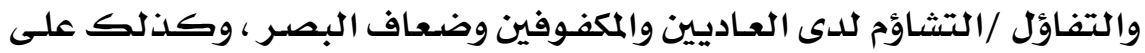

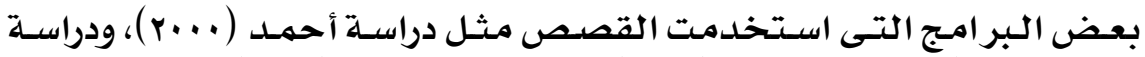

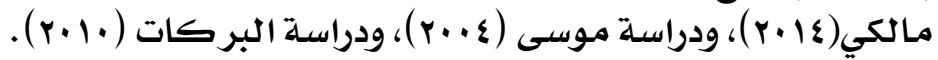

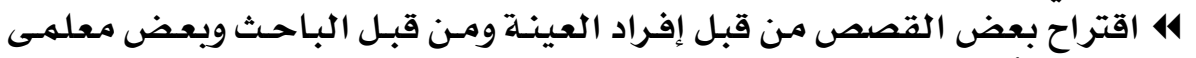

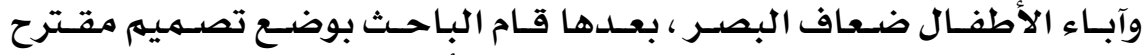

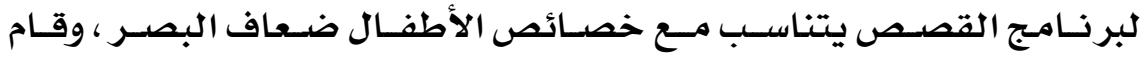

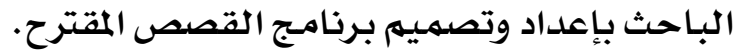

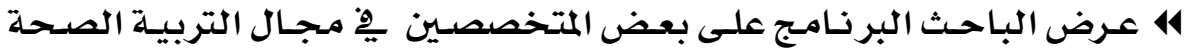

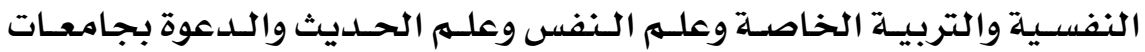
الأزهر وطنطا والزقازيق والستويس السيس .

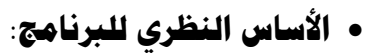

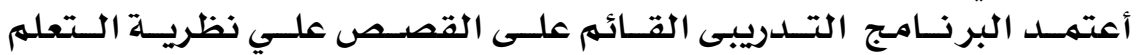

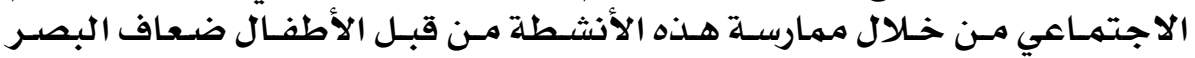

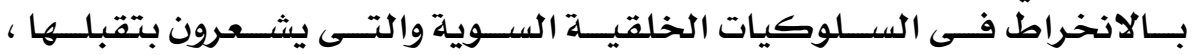

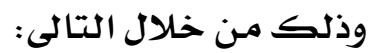

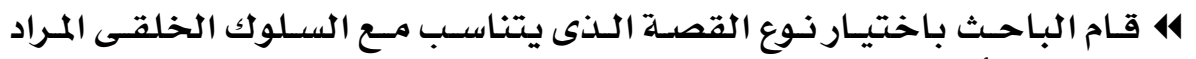

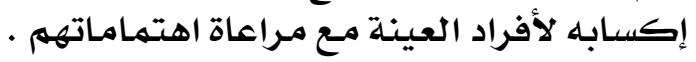

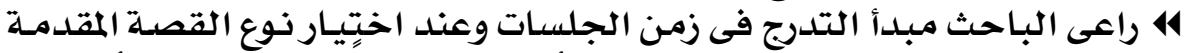

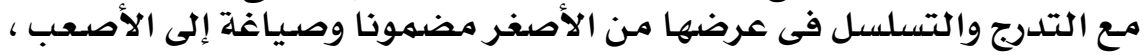

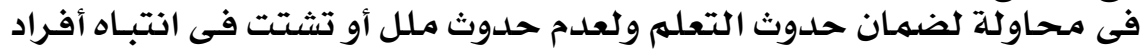

\section{$r \& 1$}


العضد التخاسع والخمسول ..الجزء الثخانىى.. هارس ..

• أهمية برناهج الأنشطة الفنية:

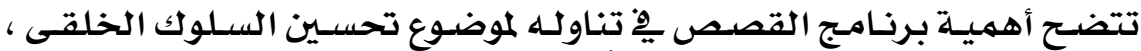

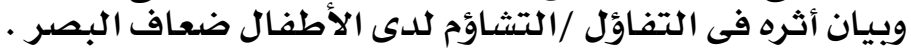

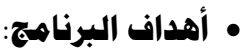

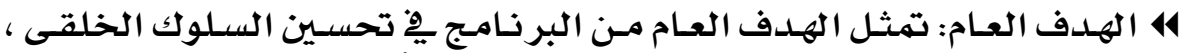

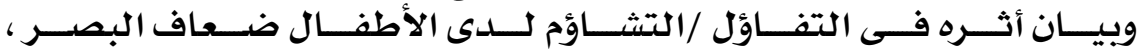

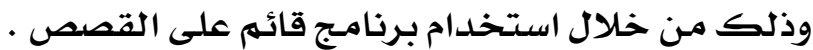

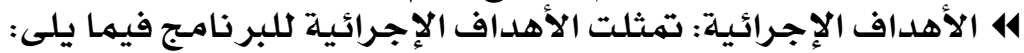
$\checkmark$

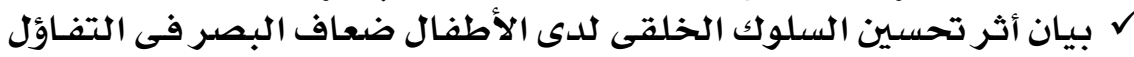

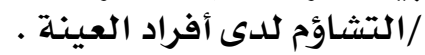

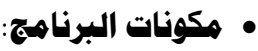

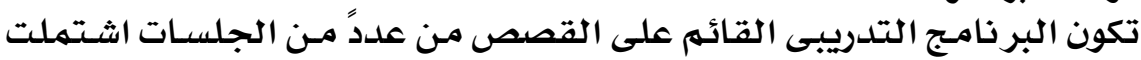

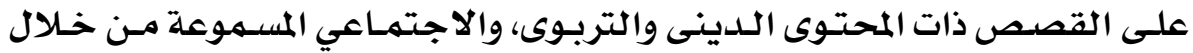

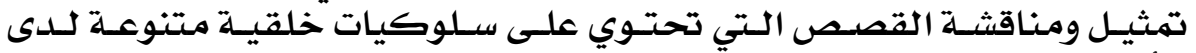
الأطفال ضعاف ومنافثة البصر. • الدراسة الاستطلاعية:

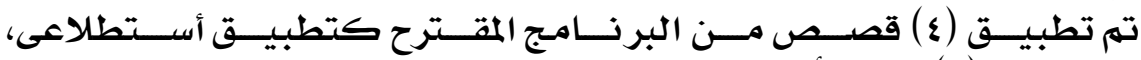

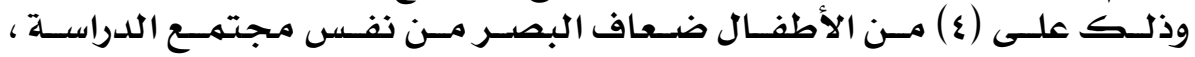

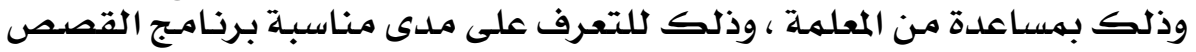

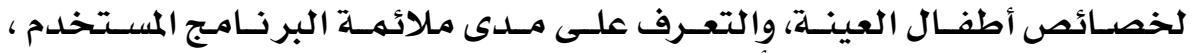

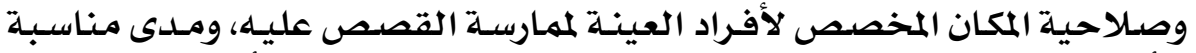

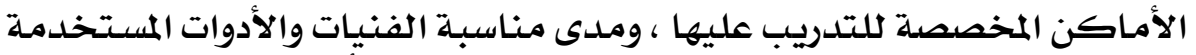

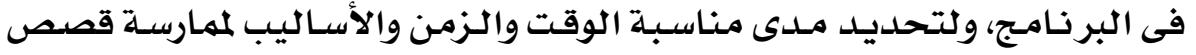
البرنامـج.

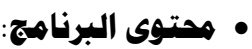

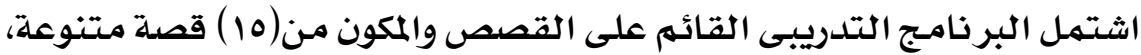

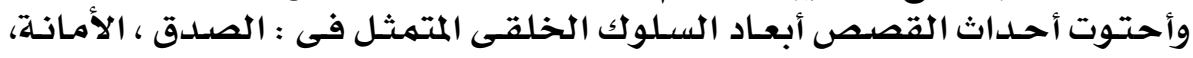

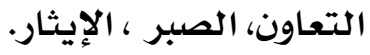

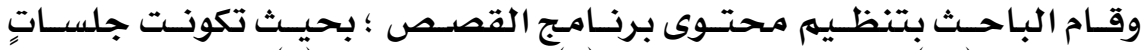

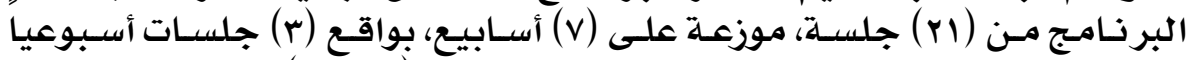

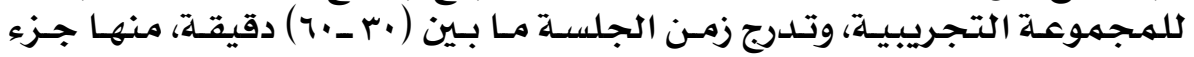

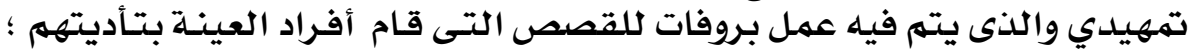

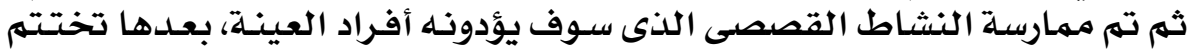

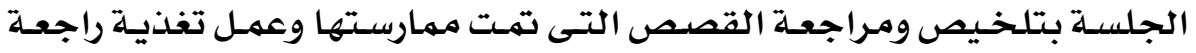

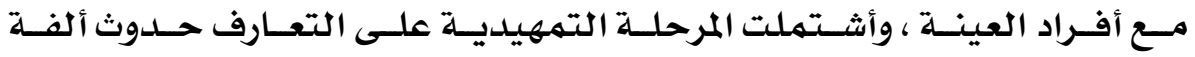

\section{$Y \& Y$}




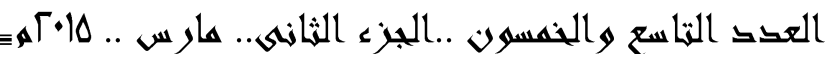

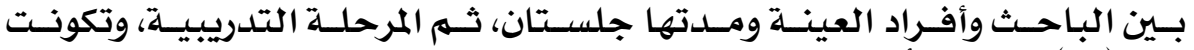

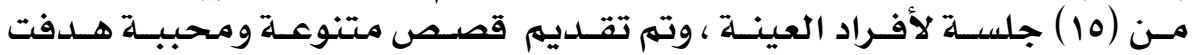

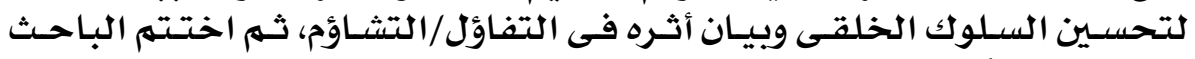

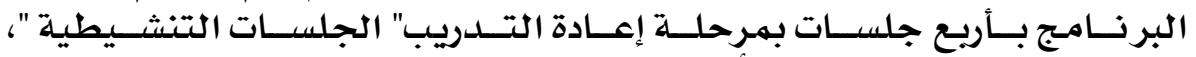

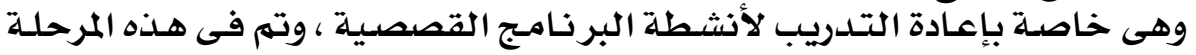

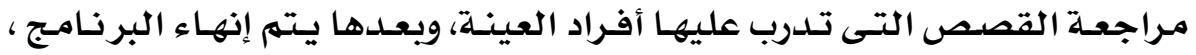

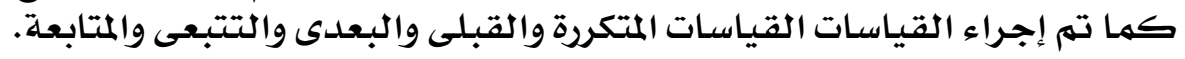

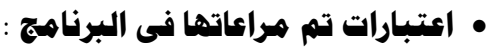

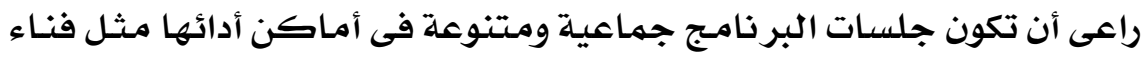

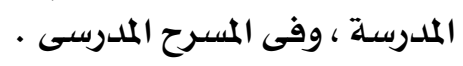

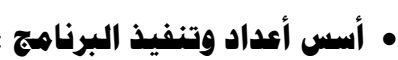

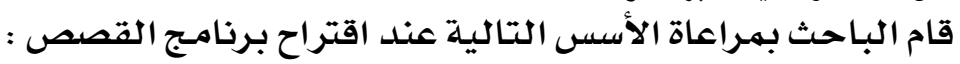

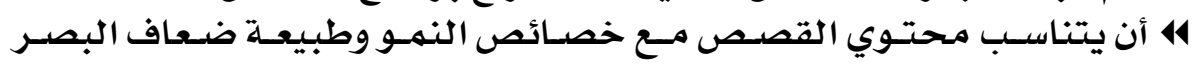

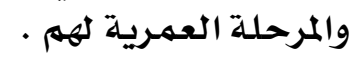

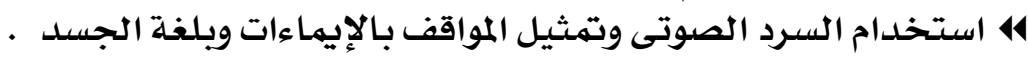

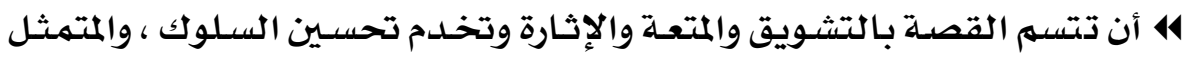

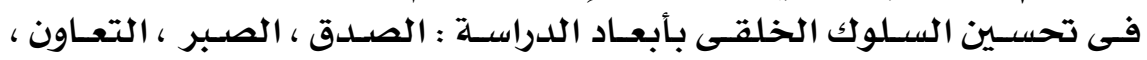

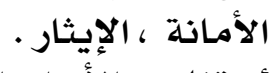

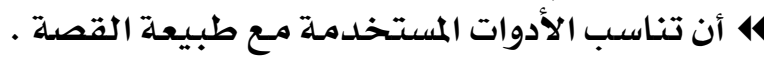

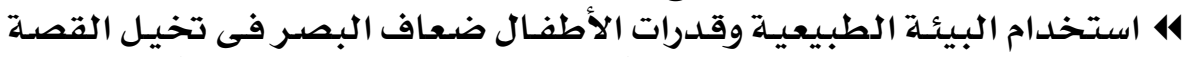

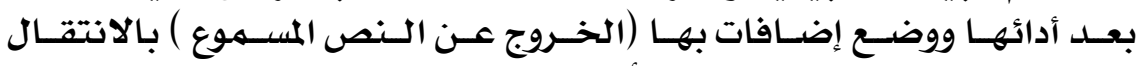

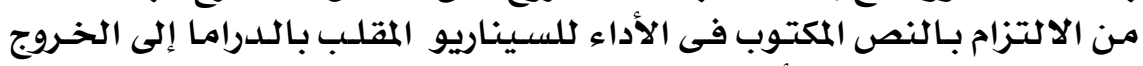

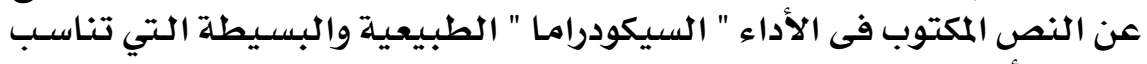

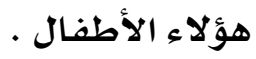

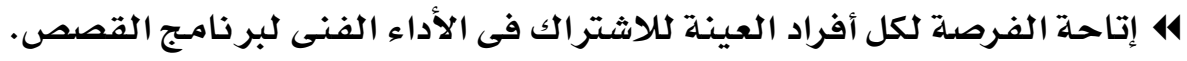

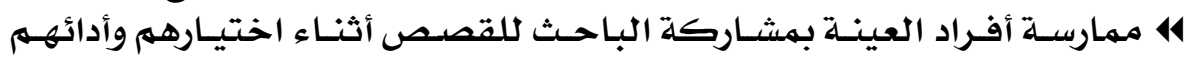

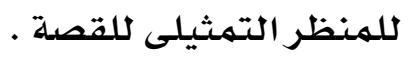

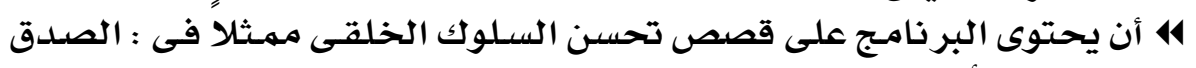

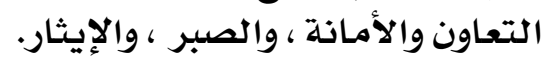

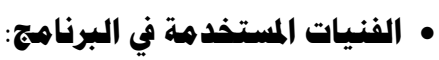

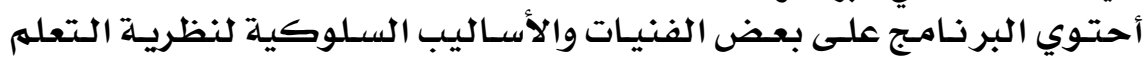

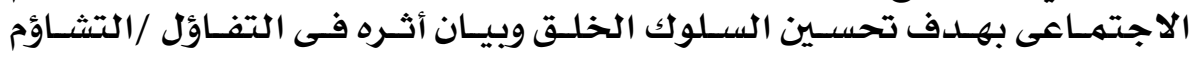

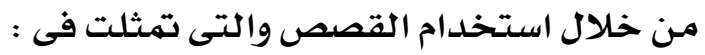

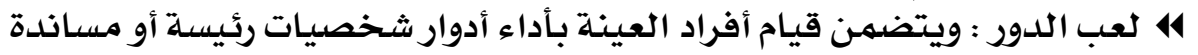

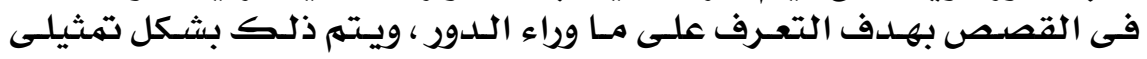

\section{$r \varepsilon Y$}


العكد التزاسع والخمسول ..الجزء الثخانىى.. هارس ..

يحتـوى على مشـاهدة واقعيـة لسـلوكيات يـتم التعـرف عليهـا مـن قبـل أفـراد

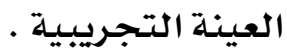

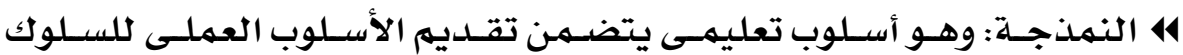

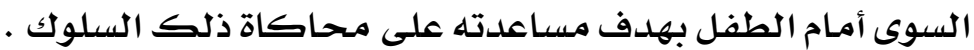

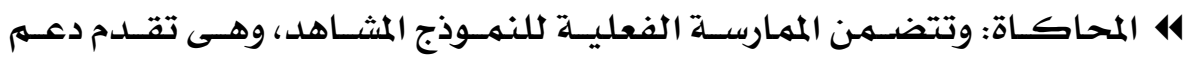
للمشاهدة الفعلية للنموذج.

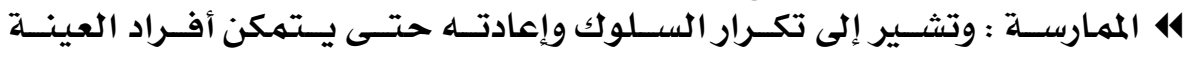

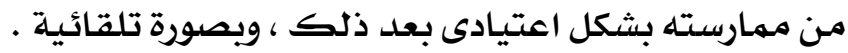

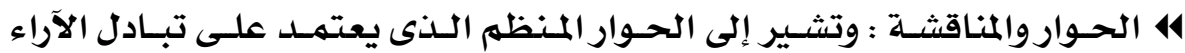

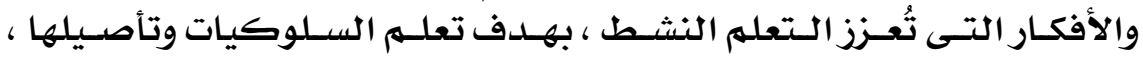

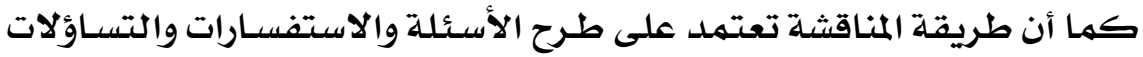

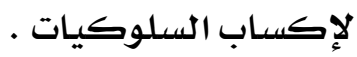

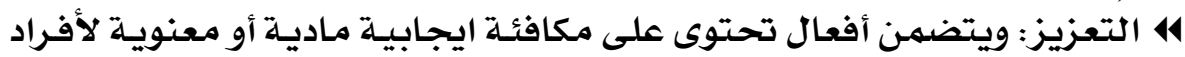

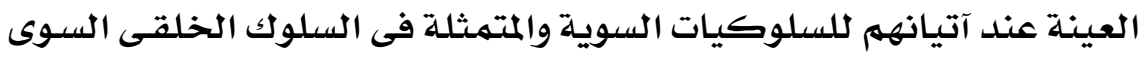

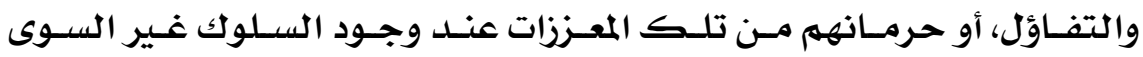

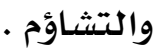

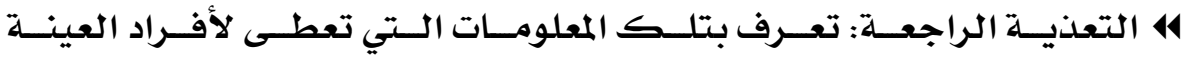

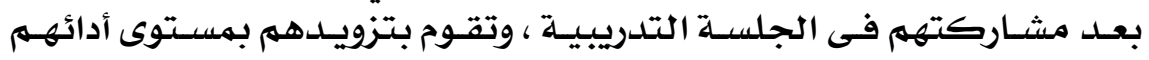

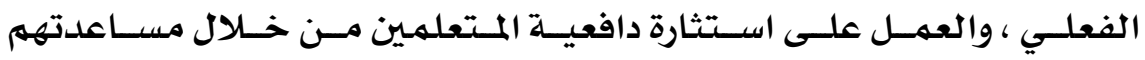

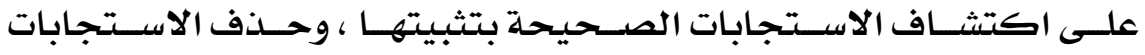
الخاطئة.

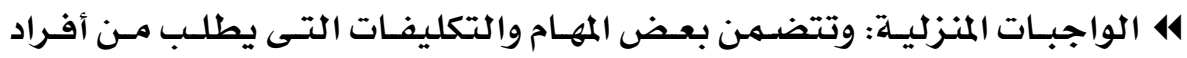

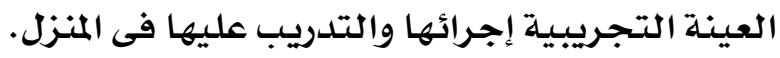

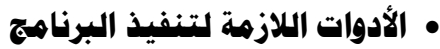

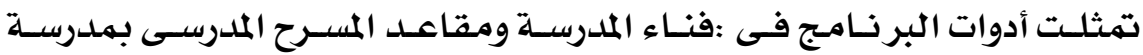

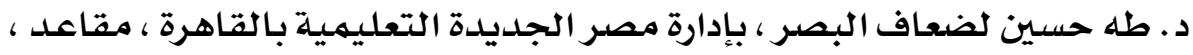

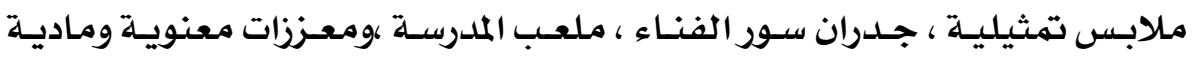

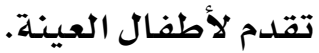

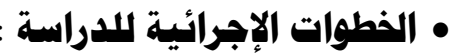

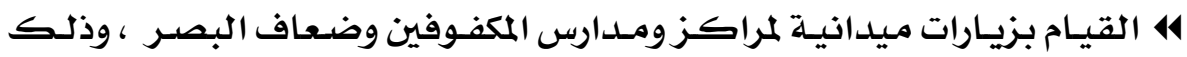

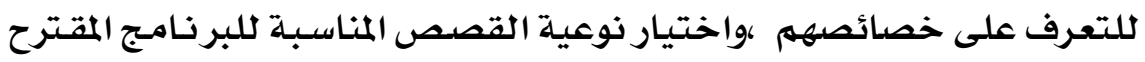

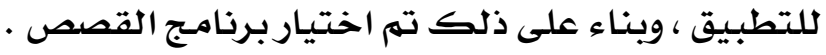

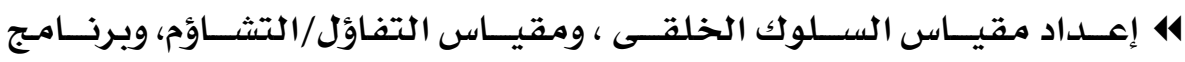
القصص.

\section{$Y \varepsilon \varepsilon$}




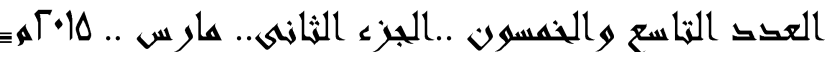

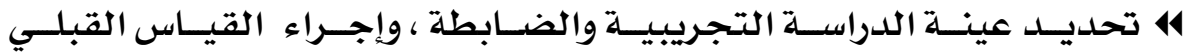

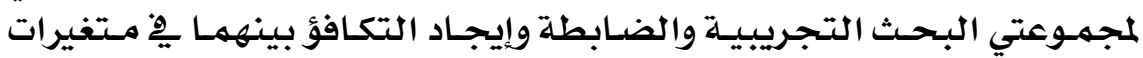

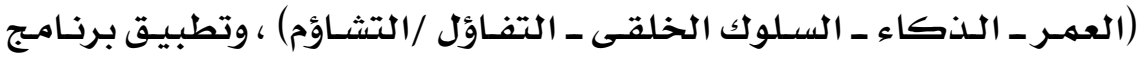

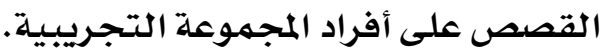

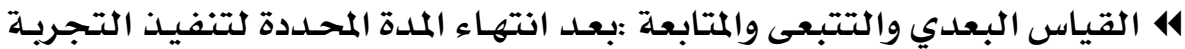

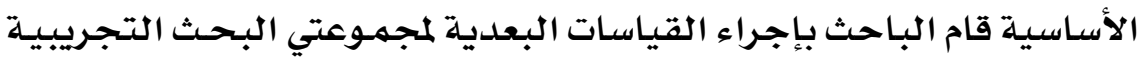

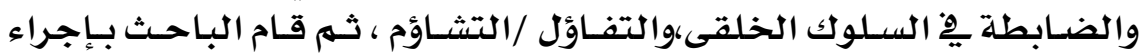

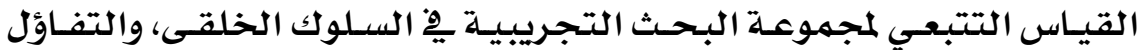

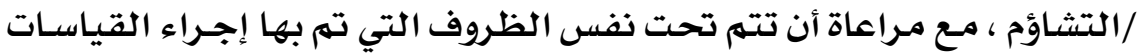

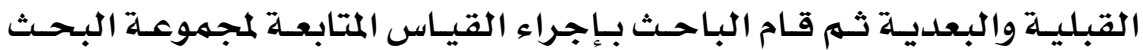

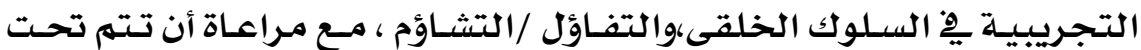

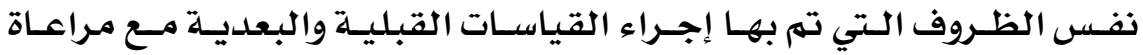

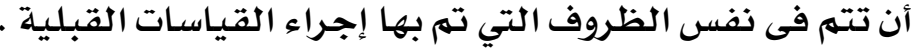

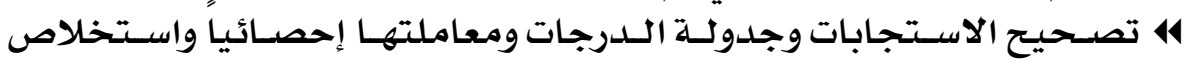

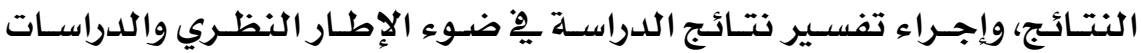

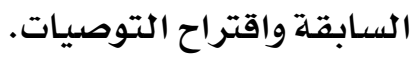

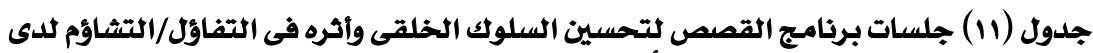
الأطفال ضعاف البصر التصري

\begin{tabular}{|c|c|c|c|}
\hline نوع القصص & الزمن & التشكيل & رقم الجلسـة \\
\hline \multicolumn{4}{|c|}{ المرحلة التمهيدية (التعارف ) } \\
\hline 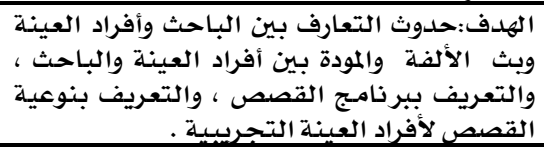 & من·r إلىهب & $\begin{array}{ll} & \phi \\
\phi & \phi \\
i & \phi\end{array}$ & الجلستان الأولى والثانية \\
\hline \multicolumn{4}{|c|}{ المرحلة التدريبية (ممارسة القصص ) } \\
\hline نوع القصص & الزمن & التشكيل & رقم الجلسـة \\
\hline 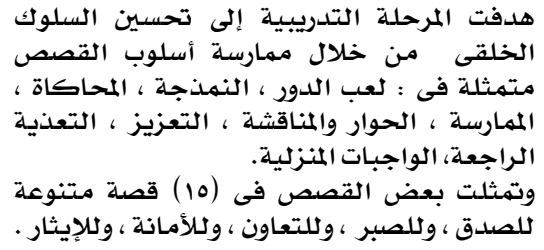 & 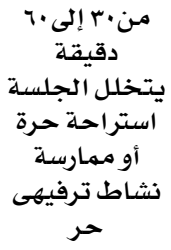 & $\phi_{i}^{\phi}$ & إلى الجلسة الثالثة \\
\hline \multicolumn{4}{|c|}{ مرحلة إعادة التدربـ } \\
\hline نوع القصص & 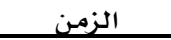 & التشكيل & رقم الجلسـة \\
\hline 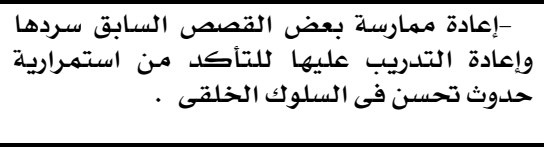 & إلى.ج دقيقة & $i_{i}^{i \phi}$ & 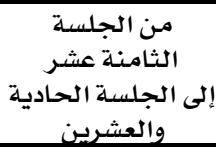 \\
\hline
\end{tabular}

\section{$r \leqslant 0$}


العكد التزاسع والخمسول ..الجزء الثخانىى.. هارس ..

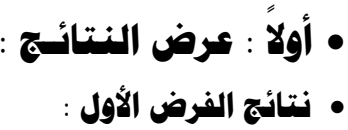

ينص الفرض الأول على أنه " لا توجد فروق دالة الحصائياً بين متوسطي رتب التبات

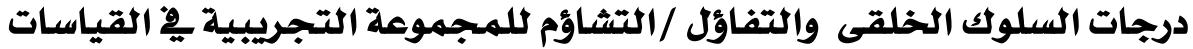

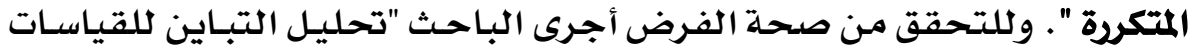

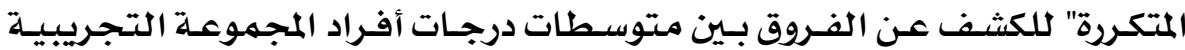

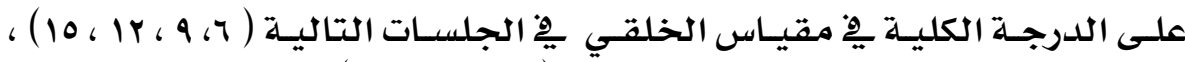

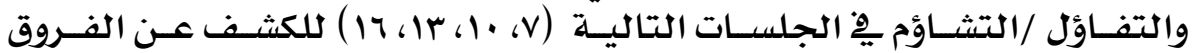

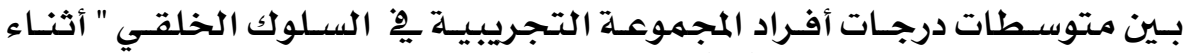

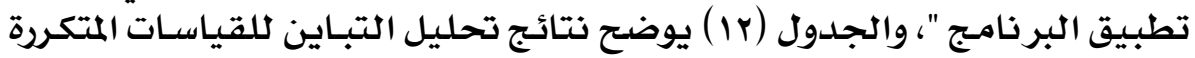

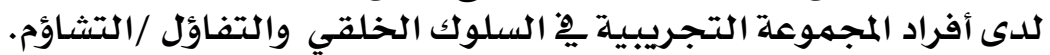

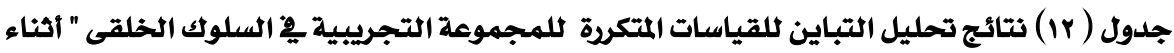

\begin{tabular}{|c|c|c|c|c|c|c|}
\hline مستوى الدلادة & قيمة & متتوسط المربعات & درجاتهـ & المربعات & مصدر التبـاين & أبعاد السلوك \\
\hline \multirow{3}{*}{$\cdots \cdots 1$} & \multirow{3}{*}{$r r 9.70$} & $r \cdot 1 . r \cdot 1$ & $r$ & 9.0 .170 & القياسـات & \multirow{3}{*}{ الصدق } \\
\hline & & $. . \wedge \leqslant Y$ & 10 & Ir.Tro & الخطاً & \\
\hline & & & 11 & TIV.Vo. & المجموع الكلى & \\
\hline \multirow{3}{*}{$\cdots \cdots 1$} & \multirow{3}{*}{$r \cdot 0.7 V r$} & $10 r .111$ & $r$ & \$09. & القياسـات & \multirow{3}{*}{ التعاون } \\
\hline & & $\because V \varepsilon \varepsilon$ & 10 & $11.17 \mathrm{~V}$ & الخطأ & \\
\hline & & & 11 & $\xi v \cdot .0 \ldots$ & المجموع الكلي & \\
\hline \multirow{3}{*}{$\because \cdots 1$} & \multirow{3}{*}{ Y.T. YVY } & $17 r .10 \%$ & $r$ & $\{\wedge \uparrow .\{0 \wedge$ & القياسـات & \multirow{3}{*}{ الصبر } \\
\hline & & $\because \vee \wedge \wedge$ & 10 & $11 . v 9 r$ & الخطاً & \\
\hline & & & 11 & \$9४. YO. & المجموع الكلي & \\
\hline \multirow{3}{*}{$\cdot \cdots 1$} & \multirow{3}{*}{ rar. rar } & $r \varepsilon V .111$ & $r$ & 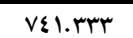 & القياسـات & \multirow{3}{*}{ الأمـانة } \\
\hline & & $\cdot . \wedge \varepsilon \varepsilon$ & 10 & IY.7TV & الخطأ & \\
\hline & & & 11 & vos.... & المجميوع الكلي & \\
\hline \multirow{3}{*}{$\cdots \cdots 1$} & \multirow{3}{*}{ r7r.A91 } & 1ヘ7. 9ะ\& & $r$ & אחו..•די & القياسـات & \multirow{3}{*}{ الإيثار } \\
\hline & & .011 & 10 & $1 . .77 \mathrm{~V}$ & الخطأ & \\
\hline & & & 11 & $0 v 1.0 \ldots$ & المجمووع الكلي & \\
\hline \multirow{3}{*}{$\cdots \cdot 1$} & \multirow{3}{*}{ } & E79Y.rVO & $r$ & IE.VV.1YO & القياسـات & \multirow{3}{*}{ الدرجة الكلية } \\
\hline & & $1 r .9 \cdot 1$ & 10 & 19r.7ro & الخطاً & \\
\hline & & & 11 & I\&rV.VO. & المجموع الكلى & \\
\hline
\end{tabular}

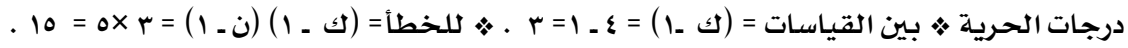

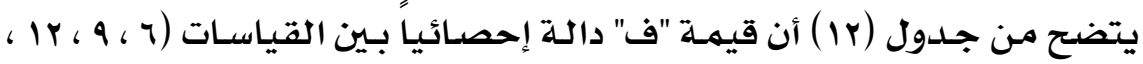

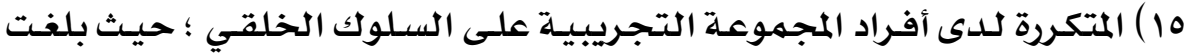

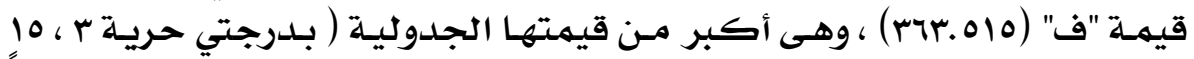

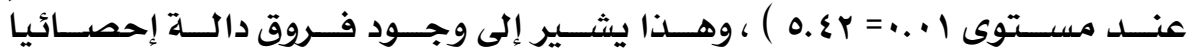

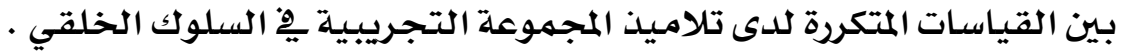

\section{$r \& 7$}


العكد التزاسع والخمسول ..الجزء الثخانىى.. هارس ..

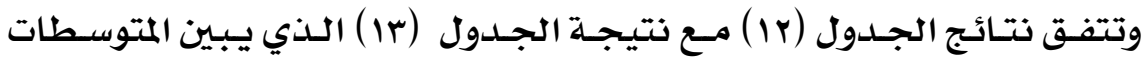

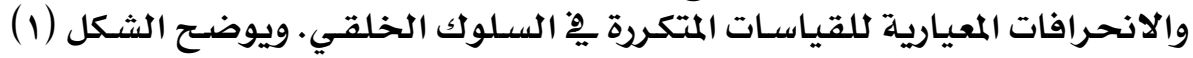

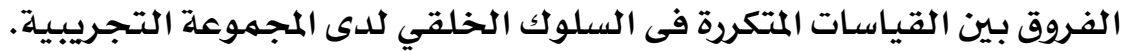

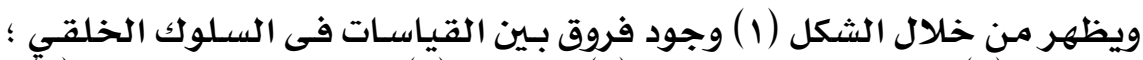

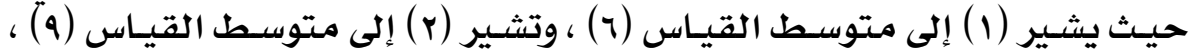

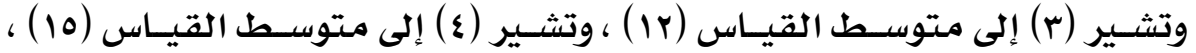

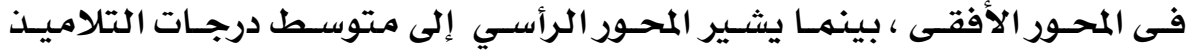

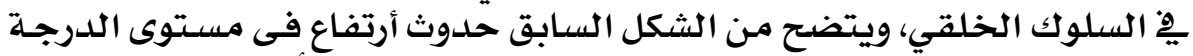

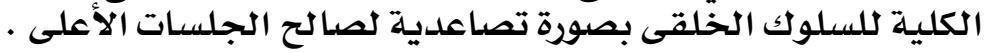

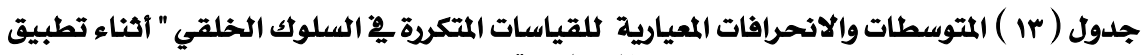

\begin{tabular}{|c|c|c|c|c|c|c|c|}
\hline الانحيارى الميى & المتوسط & القيـاســات & أبعاد السلوك الخلقى & الانحيـراف & المتوسط & القياســات & أبعاد السلوك الخلقى \\
\hline $1 . V \wedge$ & ir... & القياس ( ) ) & \multirow{4}{*}{ الأمانة } & $1 . \Sigma V$ & 17.17 & القياس ( ج ) & \multirow{4}{*}{ الصدق } \\
\hline $1 . \mathrm{mg}$ & 17. r & القيـاس (a) & & $1 . \varepsilon V$ & $1 V .17$ & القياس ( ) ) & \\
\hline $1 . \cdot r$ & Y1.77 & القيـاس( ri) & & $1 . \cdot \varepsilon$ & Y1.0. & القياس( ri) & \\
\hline .017 & YV.TT & القياس(10) & & .017 & Y7. & القياس(10) & \\
\hline $1 . Y 1$ & $1 \varepsilon .77$ & القياس ( ) ) & \multirow{4}{*}{ الإيثار } & $1 . £ V$ & 10.17 & القياس ( ج ) & \multirow{4}{*}{ التعاون } \\
\hline 1.17 & IV.Ar & القياس ( ) & & 1.17 & IV.Ar & القياس ( ) & \\
\hline 1.r & MY.rT & القياس( ri) & & .00 & r1.0. & القياس( ri) & \\
\hline $.0 \leqslant V$ & YV.O. & القياس(10) & &.$\leqslant 1$ & r...r & القياس(10) & \\
\hline V. $₹ V$ & V.rr & القياس ( ج ) & \multirow[t]{4}{*}{ الدرجة الكلية } & $1 . \varepsilon V$ & 18.17 & القياس ( r ) & \multirow{4}{*}{ الصبر } \\
\hline 0.01 & Av... & القيـيس ( ) & & $\therefore$ vo & IV.Ar & القيـاس ( ) & \\
\hline$r .9 \varepsilon$ & $1 \cdot 1.0$. & القياس( rا) & & $1 . r V$ & r1.0. & القياس( ri) & \\
\hline$\cdot . \wedge 9 \varepsilon$ & iro... & القيـاس(10) & &. .01 & (r.r & القياس(10) & \\
\hline
\end{tabular}

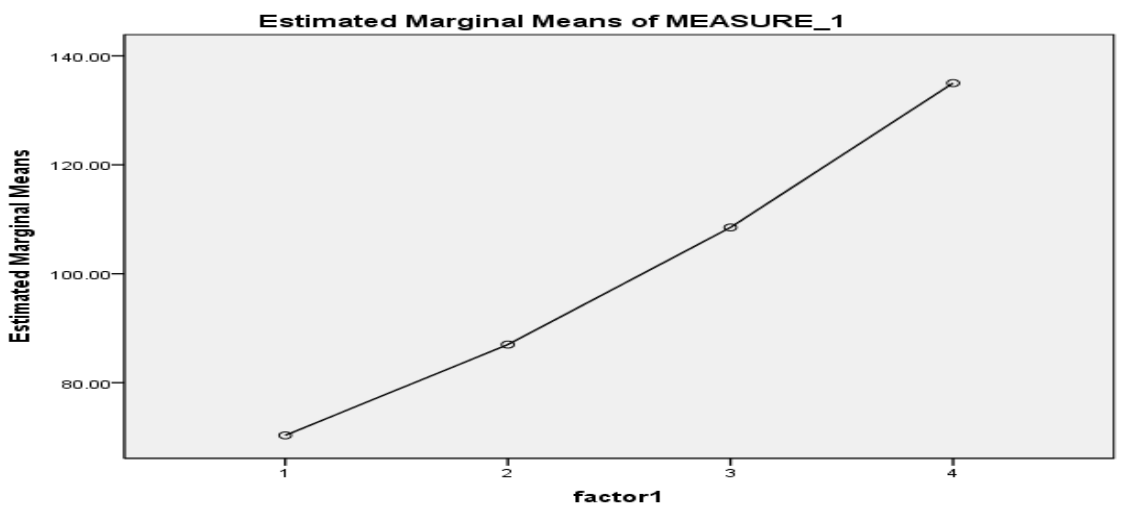

شكل ( 1 ) الفروق بين القياسات المتكررة فى الدرجة الكلية للسلوك الخلقي " أثناء تطبيق البرنامج "

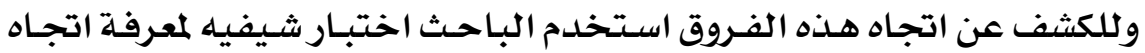

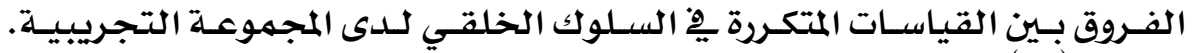

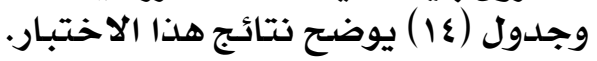

\section{$r \leqslant V$}


العكد التزاسع والخمسول ..الجزء الثخانىى.. هارس ..

جدول ( 1 ) ) نتائج اختبار شيفيه لتحديل اتجاه الفروق بين القياسات المتكررة هِ السلوك

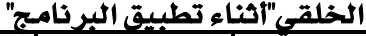

\begin{tabular}{|c|c|c|c|c|}
\hline القياس (10) & القياس (rI) & القياس (q) & القياس (7) & القياسـات المتكررة للدرجة \\
\hline 1ro... p & $1 \cdot \hat{0.0}=p$ & $\Lambda V_{.} \cdots=\beta$ & $V \cdot . r r=p$ & الكلية للسلوك الخلقى \\
\hline$\$ \$ 7 \varepsilon .77$ & $* \%$. .17 & $* *$ Y.17 & - & القياس(ד) \\
\hline$\nLeftarrow \nLeftarrow\{\Lambda \ldots$ & $*$ \% r.o. & 二 & & القياس (q) \\
\hline$\& \&$ \% . O. & - & & & القياس (ri) \\
\hline- & & & & القياس (10) \\
\hline
\end{tabular}

* * دالة عند مستوى ا ..

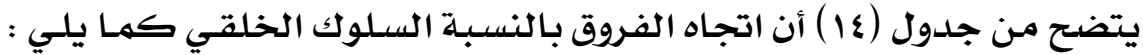

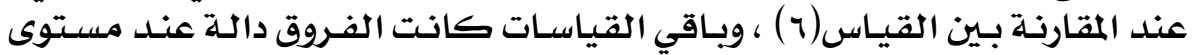

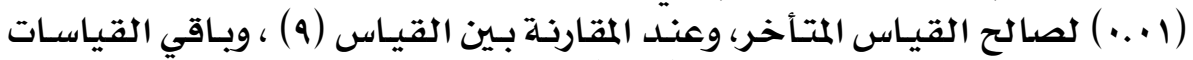

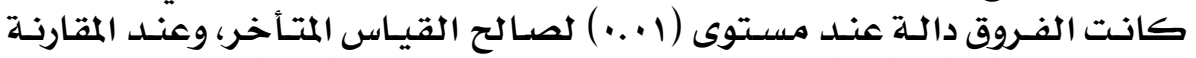

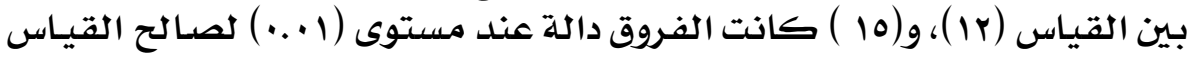
المتأخر.

جدول ( 10 ) نتائج تحليل التباين للقياسات المتكرة للمجمومة التجريبية يِ التفاؤل /التشاؤم" أنناء

\begin{tabular}{|c|c|c|c|c|c|c|}
\hline مستوى & قيمة (ف) & متوسط & الحرية & مجمبوع & مصدر التباين & أبعاد التفاؤل/التشاؤم \\
\hline \multirow{3}{*}{$\cdots \cdots 1$} & \multirow{3}{*}{ 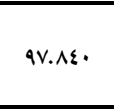 } & $97.0 \leqslant Y$ & $r$ & $19 \Lambda .1 \% 0$ & |القباسات & \multirow{3}{*}{ الإقبال على الحياة/ عدم } \\
\hline & &. TVo & 10 & $1 . .1 \% 0$ & الخطاً & \\
\hline & & & 11 & $r \cdot \Lambda . r o$. & المجمهوع الكلي & \\
\hline \multirow{3}{*}{$\cdots \cdots 1$} & \multirow{3}{*}{91.7 .0} & $\{v .111$ & $r$ & 1ह1.rTr & القياسات & \multirow{3}{*}{ الثقة بالنفس/ عدم الثقة } \\
\hline & &..$\varepsilon \mathrm{VA}$ & 10 & V.1TV & الخطأ & \\
\hline & & & 11 & $1\{\wedge .0 .$. & المجموع الكلى & \\
\hline \multirow{3}{*}{$\cdots \cdots 1$} & \multirow{3}{*}{ IVr.ovi } & $\varepsilon \cdot .0 \ldots$ & $r$ & $1 r 1.0 .$. & القياسات & \multirow{3}{*}{ الشعور بالنشاح/ الشعور } \\
\hline & &. rrr & 10 & r.o.. & الخطأ & \\
\hline & & & 11 & $1 r 0 . \ldots$ & المجموع الكلى & \\
\hline \multirow{3}{*}{$\cdots \cdots 1$} & \multirow{3}{*}{ ros.vr } & or.vVA & $r$ & 171.rrr & القياسات & \multirow{3}{*}{ للمستقبل/ النظّرة الإلسلبية } \\
\hline & &. .511 & 10 & $r .17 \mathrm{~V}$ & الخطأ & \\
\hline & & & 11 & $17 \varepsilon .0 .$. & المحجموع الكلي & \\
\hline \multirow{3}{*}{$\cdots \cdots 1$} & \multirow{3}{*}{$09 . .91$} & rq. 1111 & $r$ & 1.1. & القياسات & \multirow{3}{*}{ /الاستسلام والانسخحاب المثابرة } \\
\hline & & .711 & 10 & $9.17 \mathrm{~V}$ & الخطأ & \\
\hline & & & 11 & $1110.0 .$. & المجموع الكلى & \\
\hline \multirow{3}{*}{$\cdots \cdots 1$} & \multirow{3}{*}{$V r \varepsilon . V r 1$} & $119 V . \wedge 19$ & $r$ & roqr. \&OA & القياسات & \multirow{3}{*}{ الدرجة الكلية } \\
\hline & & $1.70 \mathrm{r}$ & 10 & r纟.Var & الخطأ & \\
\hline & & & & riा & & \\
\hline
\end{tabular}

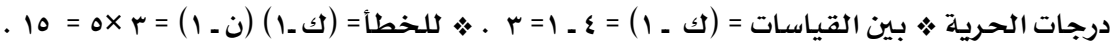

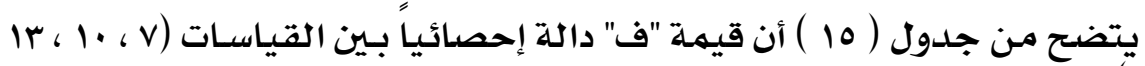

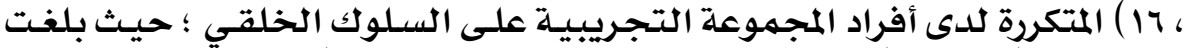

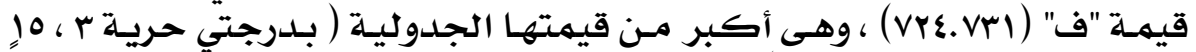

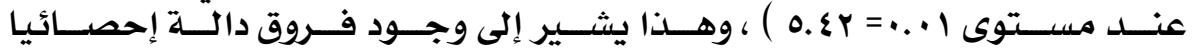

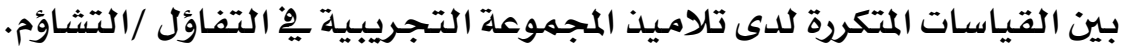

\section{$r \varepsilon \Lambda$}


العكد التزاسع والخمسول ..الجزء الثخانىى.. هارس ..

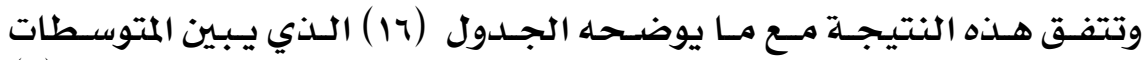

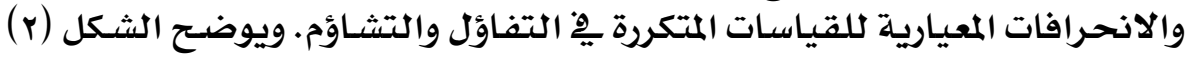

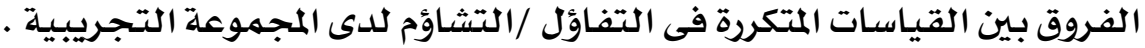

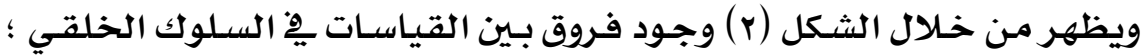

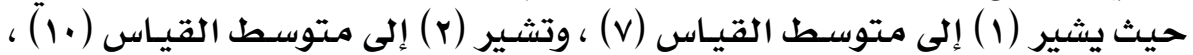

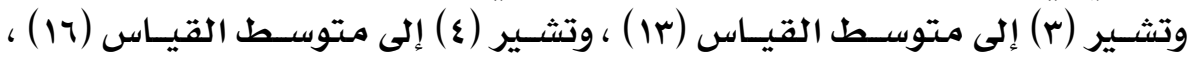

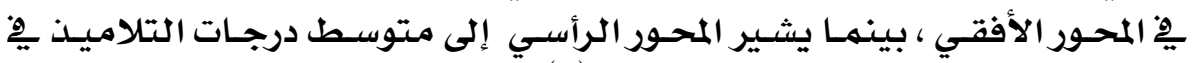

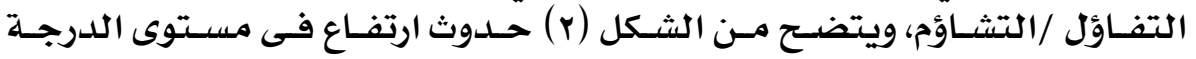

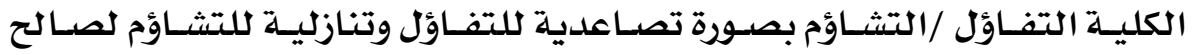

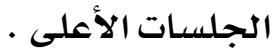

جدول ( 1 ) ) المتوسطات والانحرافات المعيارية للقياسات المتكررة يـ التفاؤل /التشاؤم " أنناء تطبيق

\begin{tabular}{|c|c|c|c|c|c|c|c|}
\hline الانحمراف & المتوسط & القياســات & البعد & الانحراف & المتوسط & القياسات & أبعاد التفاؤل / التشاؤم \\
\hline. .117 & 10.rr & القياس ( ) & \multirow{4}{*}{ 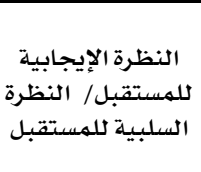 } & 1.17 & 17.17 & القياس ( v ) & \multirow{4}{*}{ الإلإقبال على الإقبال علدم على الحياة } \\
\hline צr. & IV... & القياس(· ) & & $1 . . \varepsilon$ & 10.0. & القياس(·1 ) & \\
\hline .017 & 11.77 & القياس( ri) & & $1 . . \varepsilon$ & IV.0. & القياس( ri) & \\
\hline$\cdot .117$ & Tr.r & القياس( 17) & & צrד & ri... & |القياس( 17 ) & \\
\hline $1 . .9$ & $17 .$. & القياس (v ) & \multirow{4}{*}{ والتحدي التحدابرة } & .0117 & 10.r & القياس (v) & \multirow{4}{*}{ عدم الثقة بالنفس } \\
\hline 1.17 & IV.Ar & القياس(·1 ) & & .0117 & IV.rT & القياس(· (1) & \\
\hline . vor & $19 . \wedge r$ & القياس( ri) & &. .117 & 11.77 & القياس( ri) & \\
\hline .017 & Y1.74 & القياس( 19 (1) & & $1 . .9$ & rr... & القياس( 11) & \\
\hline $1.7 \pi$ & $V \varepsilon .77$ & القياس (v) & \multirow{4}{*}{ الدرجة الكلية } & . vor & 10.17 & القياس (v) ( v) & \multirow{4}{*}{ 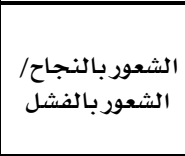 } \\
\hline r.07 & $\overline{\wedge \varepsilon . \wedge r}$ & القياس(·1 ) & & . vor & 18.17 & القياس(· (1 ) & \\
\hline r.9\& & 94.79 & القياس( ri) & & .017 & 11.77 & القياس( rا) & \\
\hline r.or & $1 \cdot 1 . \cdots$ & القياس( 19 (1) & & .017 & rI.rr & القياس( 11) & \\
\hline
\end{tabular}

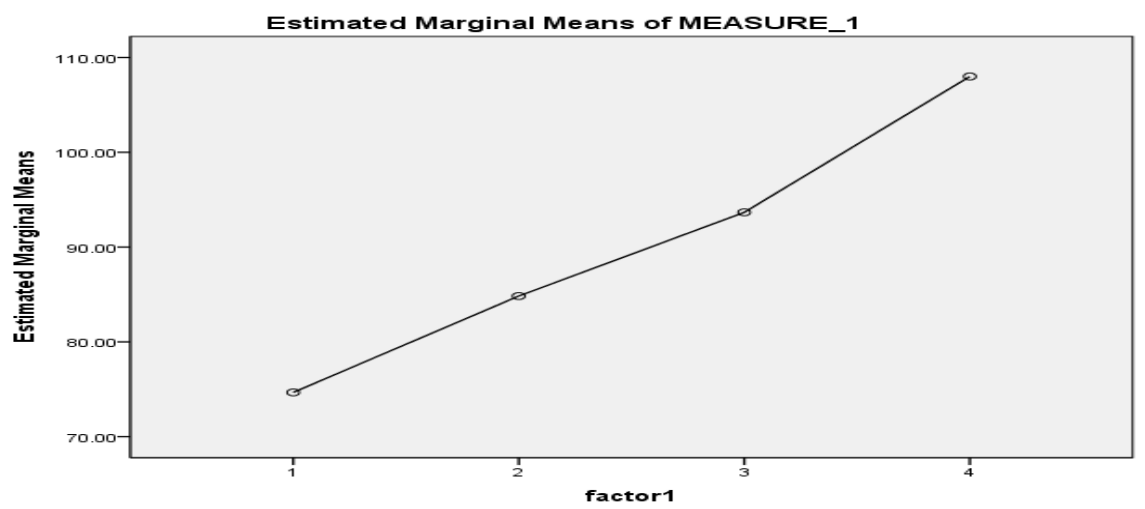

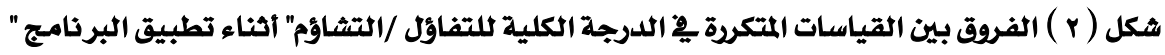

\section{r $q$}


العكد التزاسع والخمسول ..الجزء الثخانىى.. هارس ..

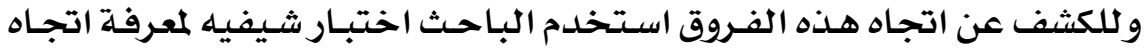

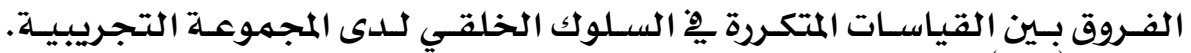

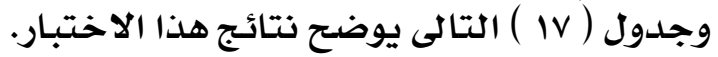

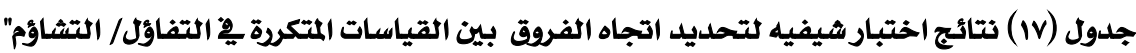

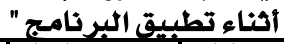

\begin{tabular}{|c|c|c|c|c|}
\hline القياس (17) & القياس (r) & القياس (1.) & القياس (v) & القياسـات المتكررة للدرجة \\
\hline $1 \cdot \Lambda_{1} \cdots=p$ & $94.77=0$ & $\Lambda \varepsilon . \wedge \mu=\rho$ & $V \varepsilon .77=p$ & الكلية للتفاؤل / التشاؤم \\
\hline$* *$ rr.r.r & $\$ \$ 19 . \cdots$ & $\$ 1 . .17$ & - & القياس(v) \\
\hline$\$ \%$ Yr. 17 & $* * \wedge . \wedge r$ & - & & القياس (1.) \\
\hline$* * 1\{. \mu r$ & - & & & القياس (rו) \\
\hline - & & & & القياس (17) \\
\hline
\end{tabular}

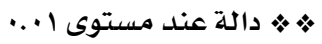

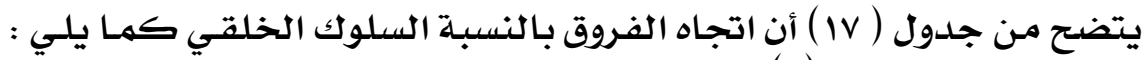

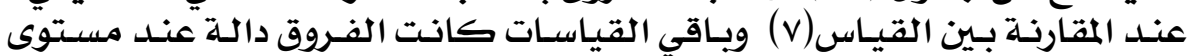

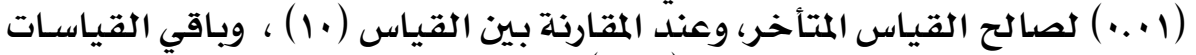

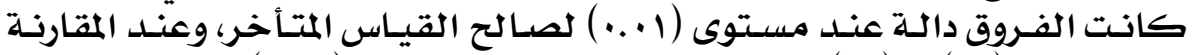

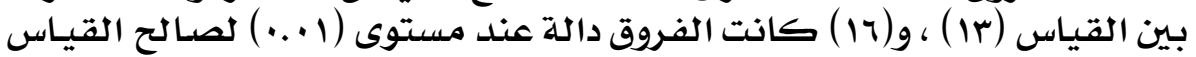
المتتأخر.

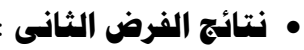

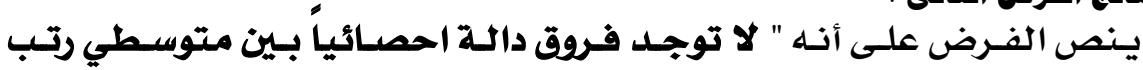

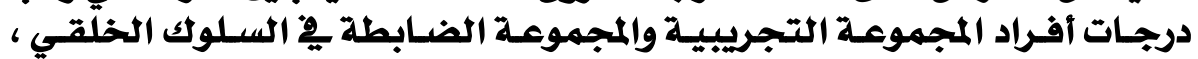

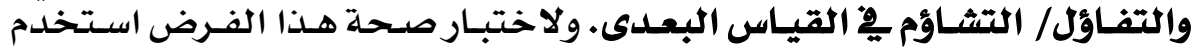

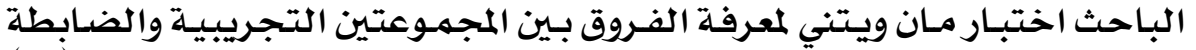

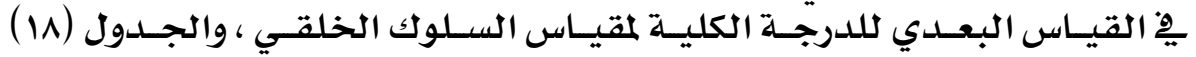
يوضح ذلك:

جدول (1) ) دلالة الفروق بين متوسطي رتب درجات أفراد المجمومتين التجريبية والضابطة فى دلى

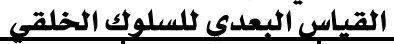

\begin{tabular}{|c|c|c|c|c|c|c|}
\hline مستوى & $\mathrm{U}$ & مجموع الرتب & متوسط الرتب & العدد & المجموعات & أبعاد السلقىك \\
\hline \multirow{2}{*}{$\cdots \cdot 1$} & \multirow{2}{*}{$\cdots \cdot \cdot$} & או... & $1 . .0$. & 7 & تحريبية & \multirow{2}{*}{ الصدق } \\
\hline & & rA... & $\varepsilon .$. & $v$ & ضابطة & \\
\hline \multirow{2}{*}{$\ldots 1$} & \multirow{2}{*}{$\cdots \cdot \cdot$} & ד.... & $1 . .0$. & 7 & تجريبيـة & \multirow{2}{*}{ التعاون } \\
\hline & & YA... & $\xi \ldots$ & $v$ & ضابطة & \\
\hline \multirow{2}{*}{$\ldots \cdot 1$} & \multirow{2}{*}{$\cdots \cdot$} & זr... & $1 . .0$. & 7 & تجريبية & \multirow{2}{*}{ الصبر } \\
\hline & & YA... & $\xi . .$. & V & ضابطة & \\
\hline \multirow{2}{*}{$\ldots+1$} & \multirow{2}{*}{$\cdots \cdot$} & Tr... & $1 . .0$. & 7 & تجريبيـة & \multirow{2}{*}{ الأمانة } \\
\hline & & ҮA... & \&... & $\mathrm{V}$ & ضابطة & \\
\hline \multirow{2}{*}{$\cdots+1$} & \multirow{2}{*}{$\cdots .}$. & ד.... & $1 . .0$. & 7 & تجريبيـة & \multirow{2}{*}{ الإيثار } \\
\hline & & ҮA... & $\xi \ldots$ & $\mathrm{v}$ & ضابطة & \\
\hline \multirow{2}{*}{$\cdots 1$} & \multirow{2}{*}{$\cdots \cdot \cdot$} & ד.... & $1 . .0$. & 7 & تجريبيـة & \multirow{2}{*}{ الدرجة الكلية } \\
\hline & & YA... & \&... & $v$ & ضابطة & \\
\hline
\end{tabular}




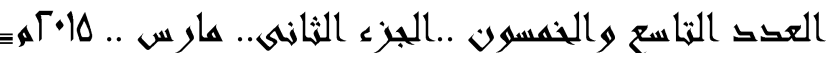

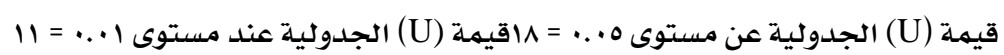

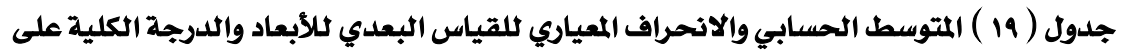

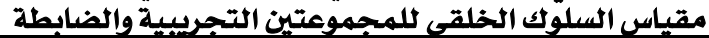

\begin{tabular}{|c|c|c|c|c|c|}
\hline \multirow{2}{*}{ الأثر } & \multicolumn{2}{|c|}{ تجريبية } & \multicolumn{2}{|l|}{ ضابطة } & \multirow{2}{*}{ السلوك أبعاد الخلقى } \\
\hline & الانحراف المعياري & المتوسط & الانحراف المعياري & المتوسط & \\
\hline .99 & $\because$ Vo & Y0.17 & 1.7. & A.VI & الصدق \\
\hline $.9 \mathrm{~V}$ & 1.7 & Y\&.7ד & $.9 V 7$ & $9 . \leqslant r$ & التعاون \\
\hline .99 & 1. & Y0.77 & $1.0 \mathrm{r}$ & $1 \cdots$ & الصبر \\
\hline .99 & 1.17 & r\&.Ar & $\because \mathrm{VAV}$ & $9.0 \mathrm{~V}$ & الأمـانة \\
\hline .99 & 1.7. & ro.A & .9877 & $1 \cdot . \Sigma Y$ & الإيثار \\
\hline .99 & א.0 & 177.17 & r. YV & $\{\wedge, 1\}$ & الدرجة الكلية \\
\hline
\end{tabular}

يتضـح مـن الجـدول (19 ) أن المتوسـط الحسـابي للهـجموعـة التجريبيـة أكبر

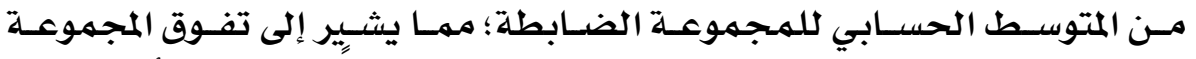

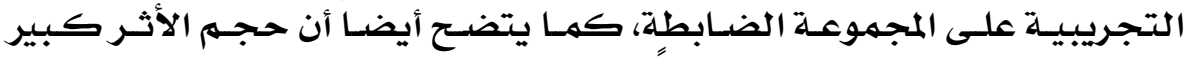

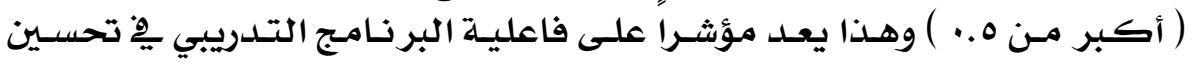
السلوك الخلقي لدى أفراد المجموعة التحريبيـية.

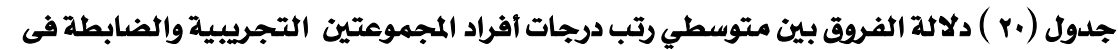

\begin{tabular}{|c|c|c|c|c|c|c|}
\hline الدستوى & $\mathrm{U}$ & مجموع & متوسط & العدد & المجموعات & أبعاد التفاؤل / التشاؤم \\
\hline \multirow{2}{*}{$\cdots \cdot 1$} & \multirow{2}{*}{$\cdots}$, & ד... & 1.0. & 7 & تجريبية & \multirow{2}{*}{ الإقبال على الحياة/ عدام الحباة } \\
\hline & & rA... & $\xi \ldots$ & $v$ & ضابطة & \\
\hline \multirow{2}{*}{$\cdots \cdot$} & \multirow{2}{*}{$\cdots \cdots$} & (r... & 1.0. & 7 & تجريبية & \multirow{2}{*}{ الثقة بالنفس/ عدم الثقة } \\
\hline & & YA... & $\varepsilon .$. & $v$ & ضابطة & \\
\hline \multirow{2}{*}{$\cdots \cdot 1$} & \multirow[b]{2}{*}{$\cdots$} & ir... & 1.0. & 7 & تجريبية & \multirow{2}{*}{ الشعور بالنجاح/ الشعور } \\
\hline & & YA... & $\xi . .$. & $\checkmark$ & ضابطة & \\
\hline \multirow{2}{*}{$\cdots \cdot 1$} & \multirow{2}{*}{$\cdots \cdot$} & Tr... & 1.0. & 7 & تجريبية & \multirow{2}{*}{ النظرة الإيجابية للمستقبل النقبل / للمسبل } \\
\hline & & Y^... & $\varepsilon . .$. & $\checkmark$ & ضابطة & \\
\hline \multirow{2}{*}{$\ldots 1$} & \multirow{2}{*}{$\cdots \cdots$} & ir... & 1.0. & 7 & تجريبية & \multirow{2}{*}{ التحدي والمثابرة /الاستسلام } \\
\hline & & Y^... & $\varepsilon . .$. & $\mathrm{v}$ & ضابطة & \\
\hline \multirow{2}{*}{$\cdots+1$} & \multirow{2}{*}{$\cdots \cdot \cdot$} & (r... & 1.0. & 1 & تجريبية & \multirow{2}{*}{ الدرجـة الكلية } \\
\hline & & Y^... & $\varepsilon . .$. & $\checkmark$ & ضابطة & \\
\hline
\end{tabular}

قيمة (U) الجدولية عن مستوى ه ... = 1

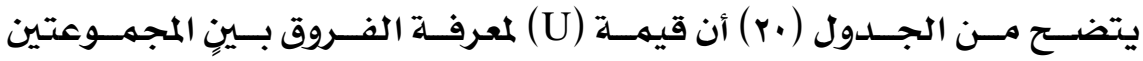

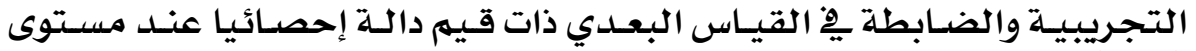

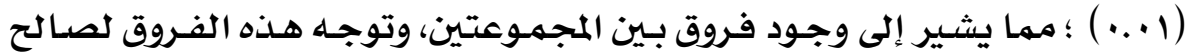

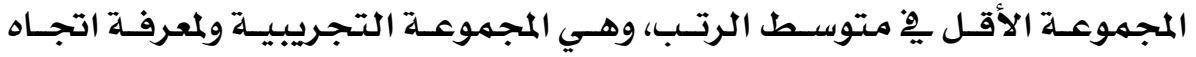

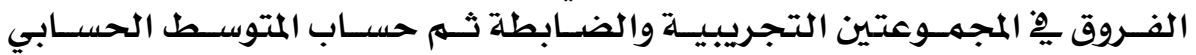

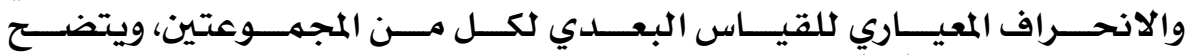

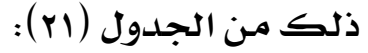

\section{Y०1}




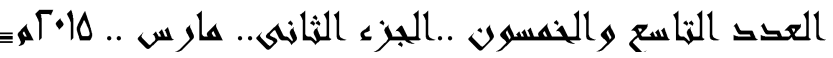

\begin{tabular}{|c|c|c|c|c|c|}
\hline \multirow[b]{2}{*}{ الأثر } & \multicolumn{2}{|c|}{ تجريبية } & \multicolumn{2}{|c|}{ ضابطة } & \multirow{2}{*}{ التفاؤل/ البعاد التشاؤم } \\
\hline & الانحـراف & المتوسط & الانحراف المعياري & المتوسط & \\
\hline. .99 & $\cdot .19$ & r£... & $1.0 \mathrm{~V}$ & $\Lambda . \wedge 0$ & الإقبال على الحياة/ عدم الإقبال على الحياة \\
\hline. $.9 \mathrm{~V}$ & 1. & rE.rY & $1.1 \%$ & V. $\{r$ & الثقة بالنفس/ عدم الثقة بـالنفس \\
\hline. .99 &. .19 & Yo... & $\cdot . £ \wedge$ & v.VI & بـالشعور بـالنـحاح/ الشعور بـالفشل \\
\hline. .99 & $\because$ Vo & Yะ.17 & 1.11 & $\mathrm{~V} . \mathrm{OV}$ & 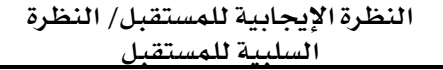 \\
\hline. .99 & 1.0 & Y乏.०. & 1.71 & A. $\mathrm{OV}$ & التحدى والمثابرة /الاستسلام والانسحـاب \\
\hline. .99 & $1 . \S 1$ & Irr... & $r .1 \Lambda$ & $\varepsilon \cdot .1 \varepsilon$ & الدرجة الكليـة \\
\hline
\end{tabular}

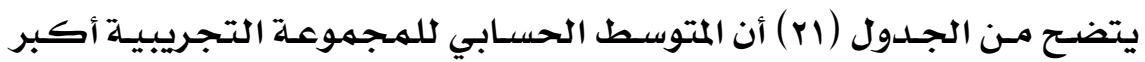

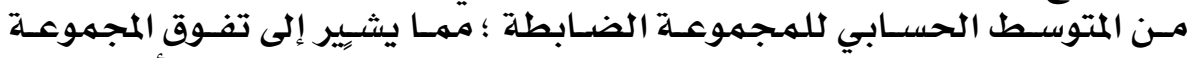

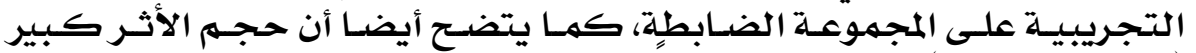

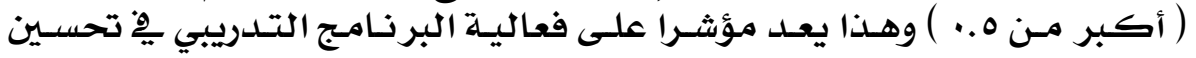

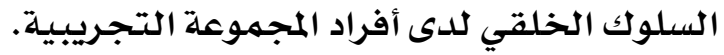

• نتائج الفرض الثالث :

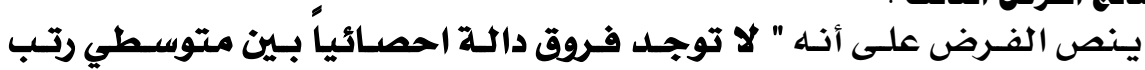

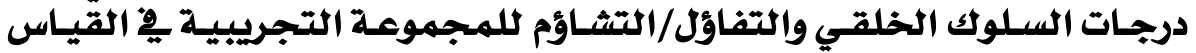

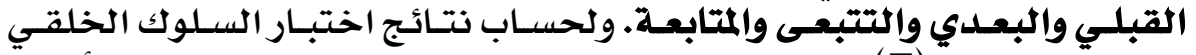

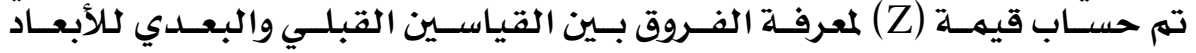

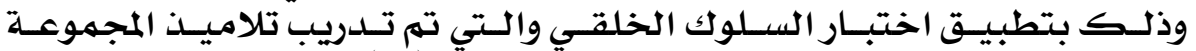

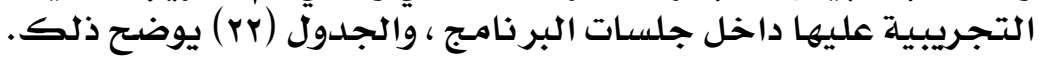

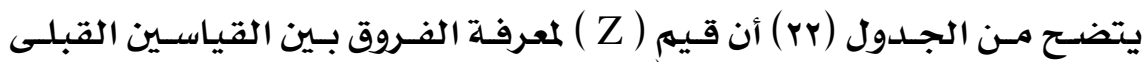

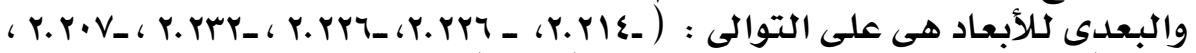

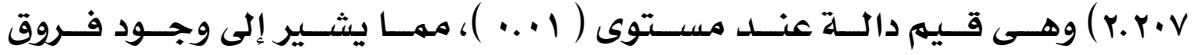

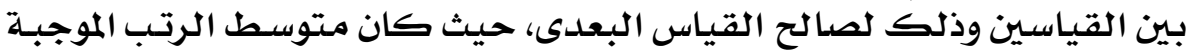

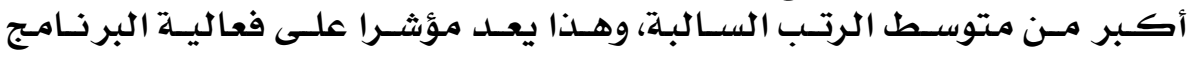

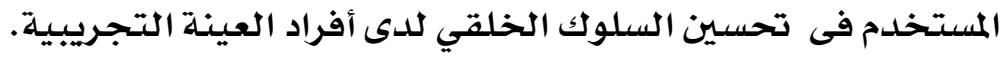

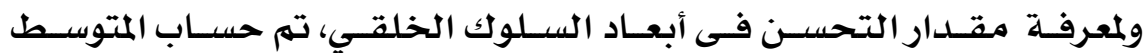

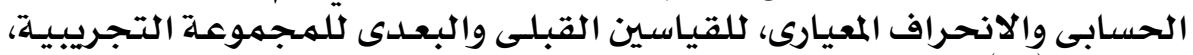

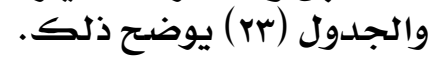

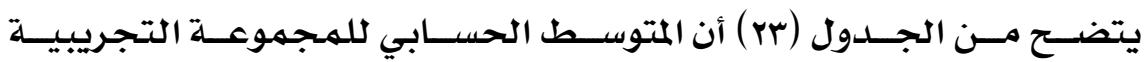

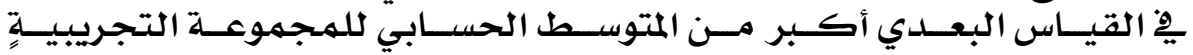

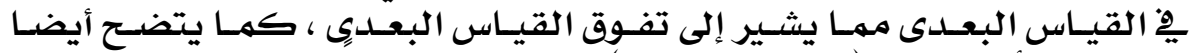

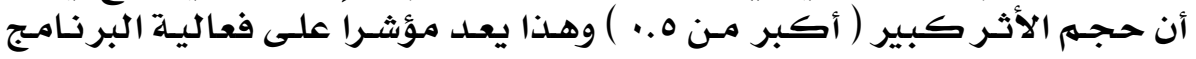

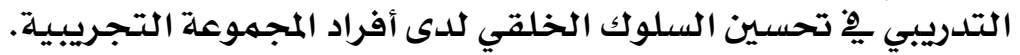

\section{Y०Y}




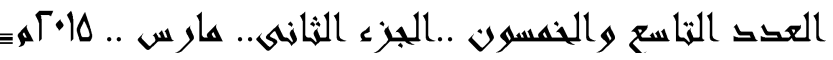

جدول (rr ) قيمة (Z) لمعرفة الفروق بين القياسين القبلى والبعدى لأبعاد السلوك الخلقي والدرجة

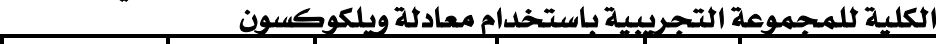

\begin{tabular}{|c|c|c|c|c|c|c|}
\hline مستتوى الدلاكية & قيمة Z & مجرتبوع & متوسط الرتب & العدد & الرتب & أبعاد السلوك الخلقى \\
\hline \multirow{4}{*}{$\because \cdot r$} & \multirow{4}{*}{ Y.YIE- } & . & . & . & الرتب السـالبـة & \multirow{4}{*}{ الصدق } \\
\hline & & YI... & r.o. & 7 & الرتب الموجبة & \\
\hline & & & & - & التسـاوى & \\
\hline & & & & 7 & المجمهوع & \\
\hline \multirow{4}{*}{$\because \cdot r$} & \multirow{4}{*}{ Y.YYT- } & . & . & . & الرتب السـالبـة & \multirow{4}{*}{ التعاون } \\
\hline & & YI... & r.o. & 7 & الرتب الموجبـة & \\
\hline & & & & . & التساوى & \\
\hline & & & & 7 & المجمهوع & \\
\hline \multirow{4}{*}{$\because \cdot r$} & \multirow{4}{*}{ Y.YYT- } & $\cdot$ & . & + & الرتب السـالبـة & \multirow{4}{*}{ الصبر } \\
\hline & & rI... & r.o. & 7 & الرتب الموجبة & \\
\hline & & & & . & التسـاوى & \\
\hline & & & & 7 & المحموع & \\
\hline \multirow{4}{*}{$\cdot \cdot r$} & \multirow{4}{*}{ Y.YMr- } & . & . & $\cdot$ & الرتب السـالبة & \multirow{4}{*}{ الأمـانة } \\
\hline & & rI... & r.o. & 7 & الرتب الموجبـة & \\
\hline & & & & $\cdot$ & التسـاوى & \\
\hline & & & & 7 & المجموع & \\
\hline \multirow{4}{*}{$\because \cdot r$} & \multirow{4}{*}{$r \cdot Y \cdot V-$} & $\cdot$ & . & $\cdot$ & الرتب السـالبـة & \multirow{4}{*}{ الإيثار } \\
\hline & & rI... & r.o. & 7 & الرتب الموجبـة & \\
\hline & & & & . & التسـاوى & \\
\hline & & & & 7 & المجموع & \\
\hline \multirow{4}{*}{$\because \cdot r$} & \multirow{4}{*}{$r \cdot Y \cdot V-$} & . & . & . & الرتب السـالبـة & \multirow{4}{*}{ الدرجة الكلية } \\
\hline & & rl... & r.o. & 7 & الرتب الموجبية & \\
\hline & & & & + & التسـاوى & \\
\hline & & & & 7 & المجموع & \\
\hline
\end{tabular}

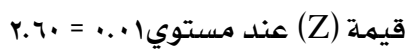

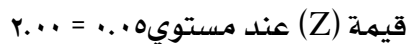

جدول ( rr) المتوسط الحسابي والانحراف المعياري للقياسين القبلي والبعدي للأبعاد والدرجة الكلية

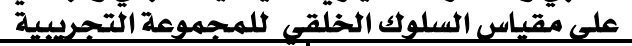

\begin{tabular}{|c|c|c|c|c|c|}
\hline \multirow{2}{*}{ حجم الأثر } & \multicolumn{2}{|c|}{ بعدي } & \multicolumn{2}{|l|}{ قبلي } & \multirow{2}{*}{ السلوك البعاد } \\
\hline & الانحراف المعياري & المتوسط & الانحراف المعياري & المتوسط & \\
\hline. .99 & $\therefore$ vo & ro.17 & 1.17 & A.Ar & الصدق \\
\hline $.9 \mathrm{~V}$ & $1.7 \pi$ & $r \varepsilon .77$ & $1 . r 9$ & $1 \cdot . \mu r$ & التعاون \\
\hline. .99 & $1.7 \pi$ & Y0.77 & $1 . \mathrm{YT}$ & $1 \ldots$. & الصبر \\
\hline. .99 & 1.17 & $r \varepsilon . \wedge r$ & $1 . . r$ & $\Lambda .77$ & الأمانة \\
\hline. .99 & 1.7. & ro.Ar & $1 . Y 1$ & $1 \cdot .74$ & الإيثار \\
\hline. .99 & E.or & $1 \times 7.17$ & r.01 & $\{\Lambda .0$. & الدرجة الكليـة \\
\hline
\end{tabular}

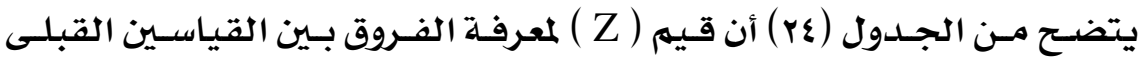

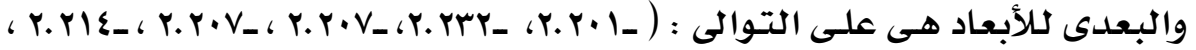

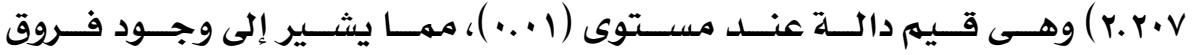

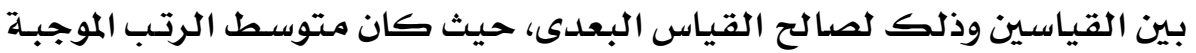

\section{ror}


العكد التزاسع والخمسول ..الجزء الثخانىى.. هارس ..

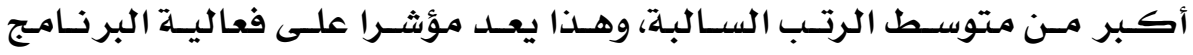

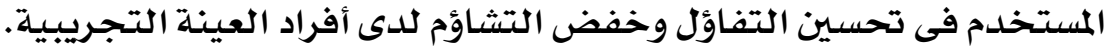

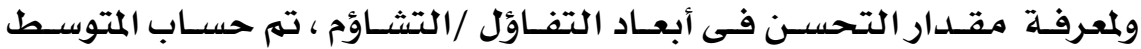

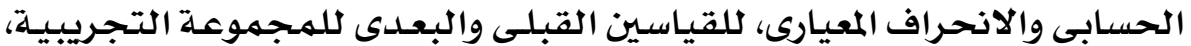
والجدول (ro ) يوضح ذلإنك.

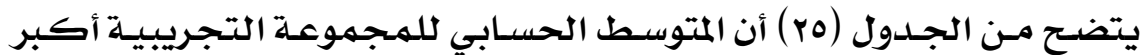

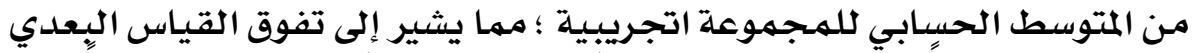

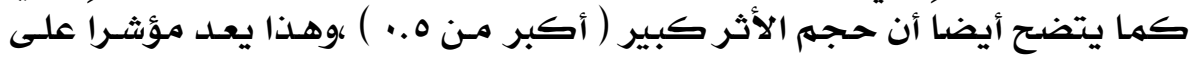

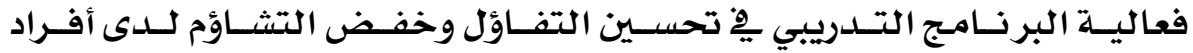
المجموعة التجريبية.

جدول ( ع ) قيمة (Z) لمعرفة الفروق بين القياسين القبلى والبعلى لأبعاد التفاؤل /التشاؤم والدرجة

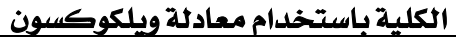

\begin{tabular}{|c|c|c|c|c|c|c|}
\hline 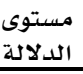 & قيمة Z & مجموع & متوسط الرتب & 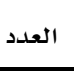 & الرتب & أبعاد التفاؤل / التشاؤم \\
\hline \multirow{4}{*}{$\because \cdot r$} & \multirow{4}{*}{ Y.Y.I - } & . & . & . & الرتب السالبـة & \multirow{4}{*}{ الإقبال على الحياة/ علدم الحبال على الحياة } \\
\hline & & rI... & r.o. & 7 & الرتب الموجبـة & \\
\hline & & & & $\dot{.}$ & التسـاوى & \\
\hline & & & & 7 & المجموع & \\
\hline \multirow{4}{*}{$\because \cdot r$} & \multirow{4}{*}{ Y.YrY- } & . & $\cdot$ & . & الرتب السـالبـة & \multirow{4}{*}{ الثقة بالنفس/ عدم الثقة } \\
\hline & & rI... & r.o. & 7 & الرتب الموجبة & \\
\hline & & & & $\dot{.}$ & التسـاوي & \\
\hline & & & & 7 & المجموع & \\
\hline \multirow{4}{*}{$\because \cdot r$} & \multirow{4}{*}{ Y.r.V- } & . & . & . & الرتب السالبـة & \multirow{4}{*}{ بالشعور بالنجاح/ الشعور } \\
\hline & & rl... & r.o. & 7 & الرتب الموجبة & \\
\hline & & & & . & التسـاوى & \\
\hline & & & & 7 & المجموع & \\
\hline \multirow{4}{*}{$\because \cdot r$} & \multirow{4}{*}{ Y.r.V- } & . & . & . & الرتب السـالبـة & \multirow{4}{*}{ النظرة الإيجابية للمستقبل / للنسبل النسبل } \\
\hline & & r.... & r.o. & 7 & الرتب الموجبة & \\
\hline & & & &. & التسـاوى & \\
\hline & & & & 7 & المجموع & \\
\hline \multirow{4}{*}{$\because \cdot r$} & \multirow{4}{*}{ Y.YI\&- } & . & $\cdot$ & . & الرتب السـالبـة & \multirow{4}{*}{ التحدي والمثابرة /الاستسلام } \\
\hline & & rI... & r.o. & 7 & الرتب الموجبة & \\
\hline & & & & . & التسـاوى & \\
\hline & & & & 1 & المجموع & \\
\hline \multirow{4}{*}{$\because r$} & \multirow{4}{*}{$r \cdot Y \cdot V-$} & . & . & . & الرتب السالبـة & \multirow{4}{*}{ الدرجـة الكلية } \\
\hline & & rI... & r.o. & 7 & الرتب الموجبـة & \\
\hline & & & & . & التسـاوى & \\
\hline & & & & 7 & المجموع & \\
\hline
\end{tabular}

\section{Y०\&}


العكد التزاسع والخمسول ..الجزء الثخانىى.. هارس ..

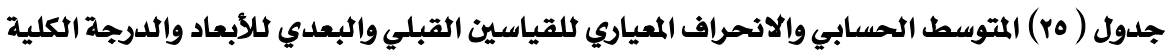

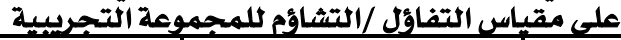

\begin{tabular}{|c|c|c|c|c|c|}
\hline \multirow{2}{*}{ حالثرم } & \multicolumn{2}{|l|}{ بعدي } & \multicolumn{2}{|l|}{ قبلى } & \multirow[t]{2}{*}{ أبعاد التفاؤل / التشاؤم } \\
\hline & الانحراف المعياري & المتوسط & الانحراف المعياري & المتوسط & \\
\hline .99 & $\cdot .19$ & r\&.. & $1 . \mathrm{rV}$ & 1. 0. & الإقبال على الحياة/ عدم الإقبـال \\
\hline. $.9 \mathrm{~V}$ & $1.7 \mathrm{r}$ & r£.rr &. .117 & V.74 & الثقة بالنفس/ عدم الثقة بالنفس \\
\hline. .99 &. .19 & ro... & $\because$ vo & A. 17 & بالشعور بـالنجـاح/ الشعور بـالفشل \\
\hline. .99 & $\because$ vo & Y\&.17 & $\because$ vo & A. 17 & النظرة الإيجابية للمستقبل النقبل / للمستبل \\
\hline. .99 & 1.00 & $r \leqslant .0$. & 1.0 & N.ru & التحلدي والمثابرة /الاستسلام \\
\hline .99 & $1 . \S 1$ & Irr... & $r . \wedge T$ & $\varepsilon \cdot . \wedge r$ & الدرجة الكلية \\
\hline
\end{tabular}

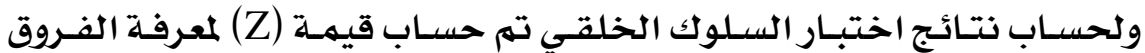

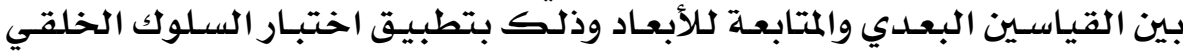

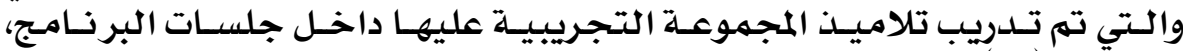

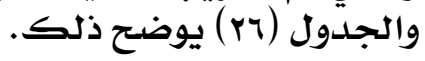

جدول (7r) قيمة (Z) لمعرفة الفروق بين القياسين البعدي والمتابعة لأبعاد السلوك الخلقي والدرجة الكلية باستخدام معادثلة وبلكوكسون

\begin{tabular}{|c|c|c|c|c|c|c|}
\hline مستوى الدلالة & قيمة Z & مجموع & متوسط الرتب & العدد & الرتب & أبعاد السلقي كي \\
\hline \multirow{4}{*}{ غير دالة } & \multirow{4}{*}{$1 \ldots-$} & $\cdot$ & $\cdot$ & $\cdot$ & الرتب السالبـة & \multirow{4}{*}{ الصدق } \\
\hline & & $1 .$. & $1 .$. & 1 & الرتب الموجبة & \\
\hline & & & & 0 & التسـاوى & \\
\hline & & & & 7 & المجموع & \\
\hline \multirow{4}{*}{ غير دالة أت } & \multirow{4}{*}{$1 . \varepsilon V r-$} & $1 .$. & $1 . .$. & 1 & الرتب السالبة & \multirow{4}{*}{ التعاون } \\
\hline & & $9 . .$. & $r . .$. & $r$ & الرتب الموجبة & \\
\hline & & & & $r$ & التسـاوى & \\
\hline & & & & 7 & المجموع & \\
\hline \multirow{4}{*}{ غير دالة } & \multirow{4}{*}{$\cdot r r Y-$} & $1{ }_{1} . .$. & $\varepsilon . .$. & $r$ & الرتب السالبة & \multirow{4}{*}{ الصبر } \\
\hline & & 9... & r... & $r$ & الرتب الموجبة & \\
\hline & & & & . & التساوى & \\
\hline & & & & 7 & المجموع & \\
\hline \multirow{4}{*}{ غير دالة } & \multirow{4}{*}{$\cdot v \varepsilon r-$} & $r . .$. & 1.0. & $r$ & الرتب السالبة & \multirow{4}{*}{ الأمانة } \\
\hline & & $v_{0} .$. & r.o. & $r$ & الرتب الموجبة & \\
\hline & & & & $r$ & التسـاوى & \\
\hline & & & & 7 & المجموع & \\
\hline \multirow{4}{*}{ غير دالة •1 • } & \multirow{4}{*}{$1 . r \varepsilon r-$} & $r . .$. & 1.0. & $r$ & الرتب السالبة & \multirow{4}{*}{ الإيثار } \\
\hline & & $\dot{.}$ & $\dot{.}$ & $\dot{.}$ & الرتب الموجبة & \\
\hline & & & & $\varepsilon$ & التسـاوي & \\
\hline & & & & 7 & المجموع & \\
\hline \multirow{4}{*}{ غير دالة } & \multirow{4}{*}{$r \cdot r \cdot V-$} & Y.O. & r.o. & 1 & الرتب السالبـة & \multirow{4}{*}{ الكلدرجة } \\
\hline & & 11.0. & r.v. & 0 & الرتب الموجبة & \\
\hline & & & & $\cdot$ & التسـاوى & \\
\hline & & & & 1 & المجموع & \\
\hline
\end{tabular}




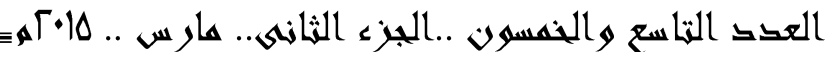

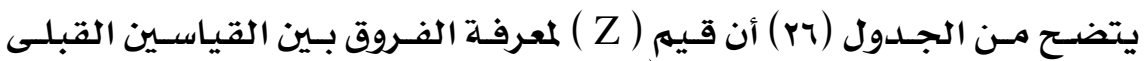

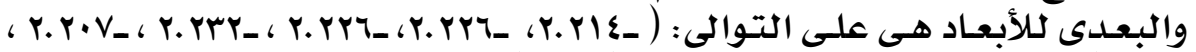

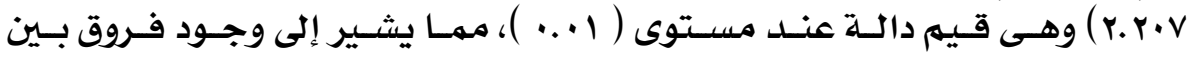

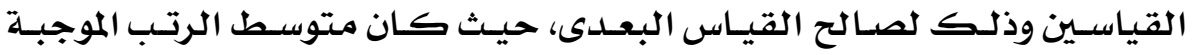

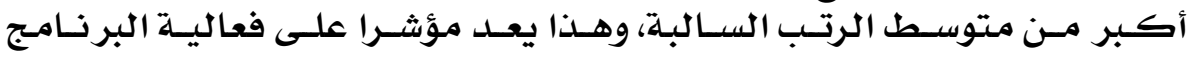

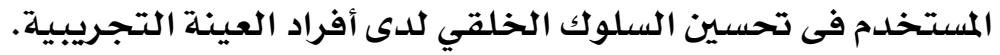

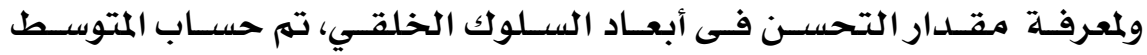

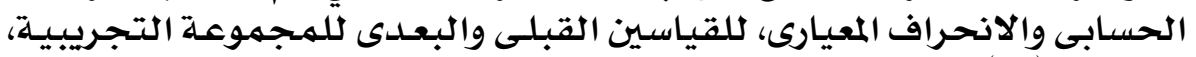

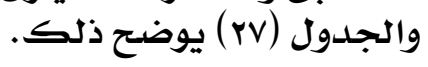

جلول (rV) المتوسط الحسابي والانحراف المعياري للقياسين البعلدي والمتابعة للأبعاد والدرجة الكلية

\begin{tabular}{|c|c|c|c|c|}
\hline \multicolumn{2}{|c|}{ متابعة } & \multicolumn{2}{|c|}{ بعدى } & \multirow{2}{*}{ السلوك البعادلقي } \\
\hline الانحراف المعياري & المتوسط & الانحراف المعياري & المتوسط & \\
\hline $1 . . r$ & ro.rr & $\therefore$. vo & ro.17 & الصدق \\
\hline . .117 & Y0.77 & $1.7 \pi$ & $r\{.77$ & التعاون \\
\hline $1 . . \varepsilon$ & ro.0. & $1.7 \pi$ & $r 0.77$ & الصبر \\
\hline 1.rv & Yo.0. & 1.17 & $r \varepsilon . \wedge r$ & الأمانة \\
\hline 1.01 & ro.rr & 1.7. & ro.Ar & الإيثار \\
\hline §. §o & IYV.rT & \&.or & $1 Y 4.17$ & الدرجة الكلية \\
\hline
\end{tabular}

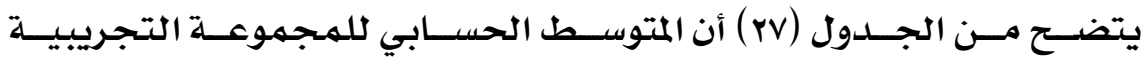

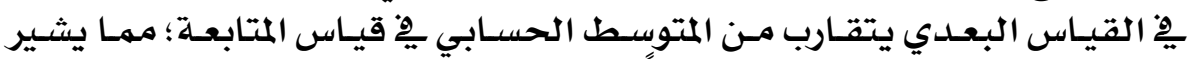

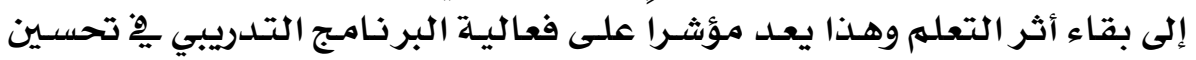

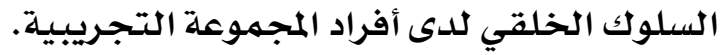

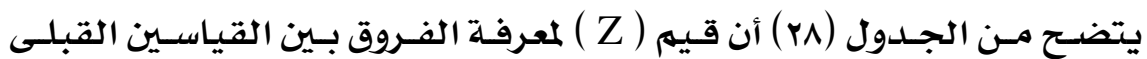

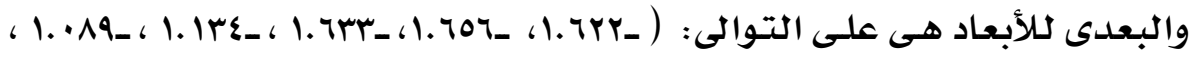

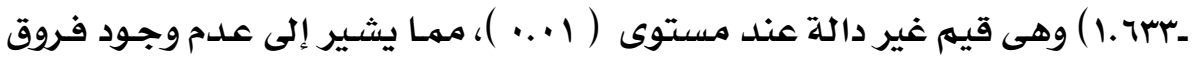

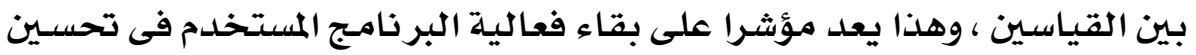
التفاؤل وخفض التشاؤم لدى أفراد العينة التجرئر التهريبية.

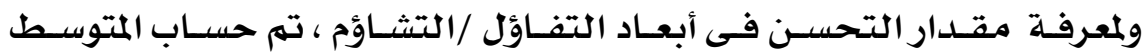

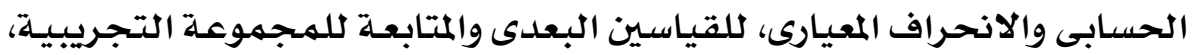

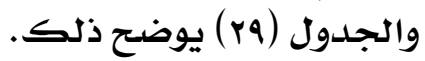

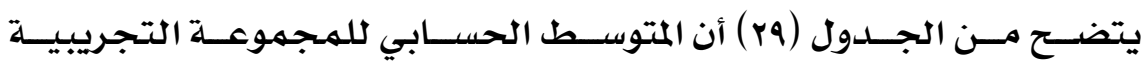

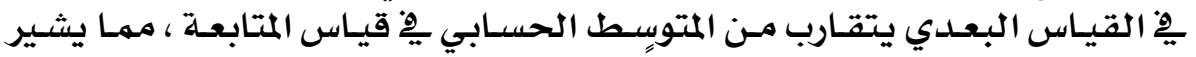

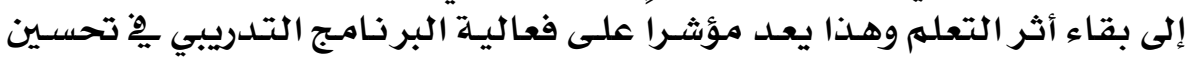

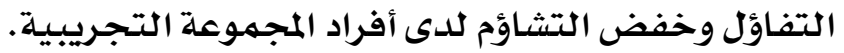

\section{YoT}




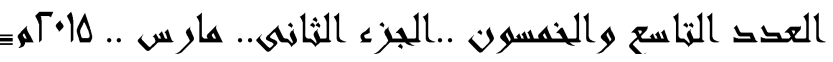

جلول (ru) قيمة (Z) لمعرفة الفروق بين القياسين البعلدي والمتابعة لأبعاد التفاؤل / التشاؤم والدرجة

\begin{tabular}{|c|c|c|c|c|c|c|}
\hline مستولي & قيمة Z & مجرموع & متوسط & العدد & الرتب & أبعاد التفاؤل / التشاؤم \\
\hline \multirow{4}{*}{ غير دالة } & \multirow{4}{*}{$\begin{array}{l}- \\
1.7 \mathrm{rr}\end{array}$} & r... & 1.0. & r & الرتب السالبة & \multirow{4}{*}{ عدم الإقبال على الحيلى الحياة/ } \\
\hline & & $1 \wedge . \cdots$ & \$.0. & $\varepsilon$ & الرتب الموجبة & \\
\hline & & & & $\cdot$ & التساوى & \\
\hline & & & & 7 & المجموع & \\
\hline \multirow{4}{*}{ غير دالة } & \multirow{4}{*}{$\begin{array}{l}- \\
1.707\end{array}$} & 1.0. & 1.0. & 1 & الرتب السالبة & \multirow{4}{*}{ الثقة بالنفس/ الثنفس عدم } \\
\hline & & 1r.0. & r.ru & $\varepsilon$ & الرتب الموجبة & \\
\hline & & & & 1 & التسـاوي & \\
\hline & & & & 1 & المجموع & \\
\hline \multirow{4}{*}{ غير دالة } & \multirow{4}{*}{ r.t. } & 7... & r... & $r$ & الرتب السالبة & \multirow{4}{*}{ بالشعور بالنجاح/ الشعورل } \\
\hline & & $\ldots$ & $\ldots$. & $\cdot$ & الرتب الموجبة & \\
\hline & & & & $r$ & التسـاوى & \\
\hline & & & & 7 & المجموع & \\
\hline \multirow{4}{*}{ غير دالة } & \multirow{4}{*}{$1.1 \% \varepsilon$} & $r_{.} \cdot$. & $r_{.} \cdot \cdot$ & 1 & الرتب السـالبة & \multirow{4}{*}{ للمستقبل الإيجابية النظرة } \\
\hline & & A... & Y.TV & $r$ & الرتب الموجبة & \\
\hline & & & & $r$ & التسـاوى & \\
\hline & & & & 7 & المجموع & \\
\hline \multirow{4}{*}{ غير دالة } & \multirow{4}{*}{$\frac{-}{1 . \cdot 19}$} & $0 . \cdots$ & r.o. & $r$ & الرتب السالبة & \multirow{4}{*}{ /الاستسلامدي والمثابرة } \\
\hline & & $1 . .$. & $1 .$. & 1 & الرتب الموجبة & \\
\hline & & & & $r$ & التساوى & \\
\hline & & & & 7 & المجموع & \\
\hline \multirow{4}{*}{ غير دالة } & \multirow{4}{*}{$\begin{array}{l}- \\
1.7 r r\end{array}$} & 1.0. & 1.0. & 1 & الرتب السالبة & \multirow{4}{*}{ الدرجة الكلية } \\
\hline & & Ir.o. & r.ru & $\varepsilon$ & الرتب الموجبة & \\
\hline & & & & 1 & التسـاوي & \\
\hline & & & & 7 & المجموع & \\
\hline
\end{tabular}

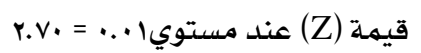

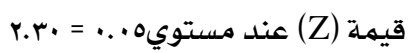

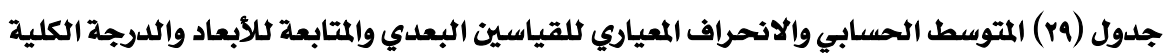

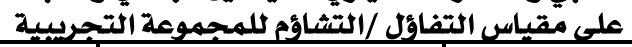

\begin{tabular}{|c|c|c|c|c|}
\hline \multicolumn{2}{|l|}{ متابعة } & \multicolumn{2}{|c|}{ بعدي } & \multirow{2}{*}{ التفاؤل / التباد اؤم } \\
\hline الانحراف المعياري & المتوسط & الانحراف المعياري & المتوسط & \\
\hline. .19 & ro... &.$\wedge 9$ & r\&... & الإقبال على الحياة/ عدم الإقبال على الحياة \\
\hline $1 . . r$ & ro.rr & $1.7 \pi$ & rצ.r & الثقة بالنفس/ عدم الثقة بالنفس \\
\hline .017 & $r \varepsilon . r r$ &. .19 & ro... & بالشعور بالنجاح/ الشعور بالفشل \\
\hline .017 & Y\&.TT & 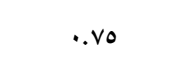 & Y\$.17 & النظرة الإيجابية للمستقبل / النظبل \\
\hline $1 . r 4$ & $r \varepsilon_{\ldots} .$. & 1.00 & Y£.0. & التحدي والمثابرة /الاستسلام \\
\hline r.MI & Irr.r & $1 . \S 1$ & Irr... & الدرجة الكلية \\
\hline
\end{tabular}

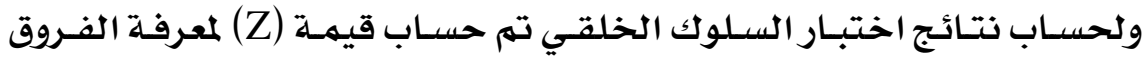

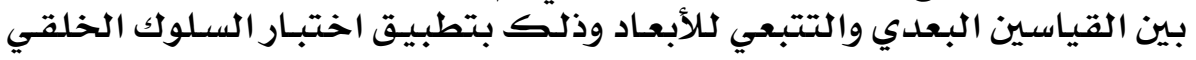

\section{YOV}




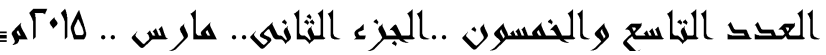

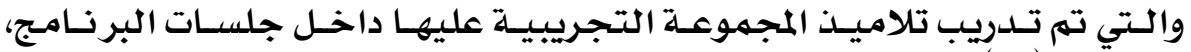

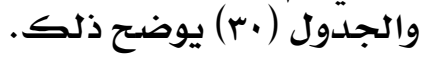

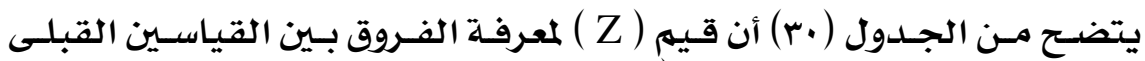

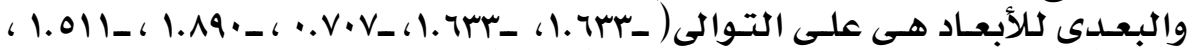

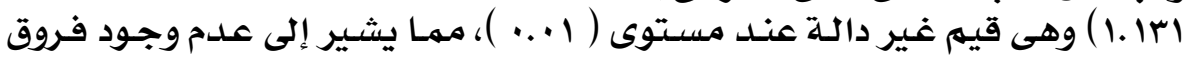

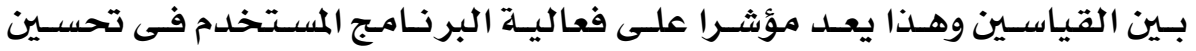

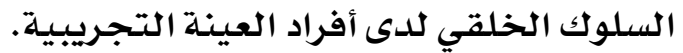

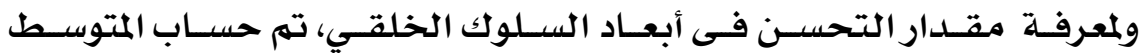

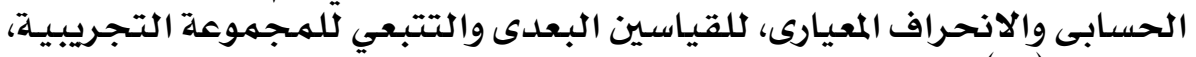

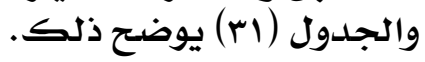

جدول (·r ) قيمة (Z) لمعرفة الفروق بين القياسين البعلدي والتتبعيلأبعاد السلوك الخلقي والدرجة

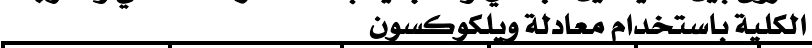

\begin{tabular}{|c|c|c|c|c|c|c|}
\hline مستوى الدلائة & قيمة Z & مجرتوع & متوسط الرتب & العددد & الرتب & السلولك الخلقلقي \\
\hline \multirow{4}{*}{ غير دالة • • } & \multirow{4}{*}{ - } & r.o. & r.o. & 1 & الرتب السـالبة & \multirow{4}{*}{ الصدق } \\
\hline & & IV.0. & r.o. & 0 & الرتب الموجبـة & \\
\hline & & & & . & التسـاوى & \\
\hline & & & & 7 & المججموع & \\
\hline \multirow{4}{*}{ غير دالة • • } & \multirow{4}{*}{ 1.7m- } & r.o. & r.o. & 1 & الرتب السـالبـة & \multirow{4}{*}{ التعاون } \\
\hline & & IV.0. & r.o. & 0 & الرتب الموجبـة & \\
\hline & & & & . & التسـاوى & \\
\hline & & & & 7 & المحموع & \\
\hline \multirow{4}{*}{ 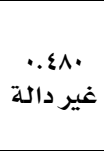 } & \multirow{4}{*}{$\cdot v \cdot v-$} & $1 \ldots$ & r.r & $r$ & الرتب السـالبة & \multirow{4}{*}{ الصبر } \\
\hline & & $0 . \cdots$ & Y.०. & r & الرتب الموجبية & \\
\hline & & & & 1 & التسـاوى & \\
\hline & & & & 7 & المحموع & \\
\hline \multirow{4}{*}{ غير دالة • • • } & \multirow{4}{*}{$1.19 \cdot-$} & $\because \cdots$ & $\because \cdot$ & . & الرتب السـالبة & \multirow{4}{*}{ الأمـانة } \\
\hline & & $1 \ldots$ & Y.O. & $\varepsilon$ & الرتب الموجبـة & \\
\hline & & & & $r$ & التسـاوي & \\
\hline & & & & 7 & المحجموع & \\
\hline \multirow{4}{*}{ غير دالة است } & \multirow{4}{*}{$1.011-$} & Ir... & r.ro & $\varepsilon$ & الرتب السـالبـة & \multirow{4}{*}{ الإيثار } \\
\hline & & r. $\cdots$ & r... & 1 & الرتب الموجبـة & \\
\hline & & & & 1 & التسساوى & \\
\hline & & & & 7 & المجمموع & \\
\hline \multirow{4}{*}{ غير دالة } & \multirow{4}{*}{$1.1 \mathrm{r1-}$} & r.o. & r.o. & 1 & الرتب السـالبـة & \multirow{4}{*}{ الدرجـة الكلية } \\
\hline & & 11.0. & r.M & $\varepsilon$ & الرتب الموجبـة & \\
\hline & & & & 1 & التساوى & \\
\hline & & & & 7 & المجمبوع & \\
\hline
\end{tabular}

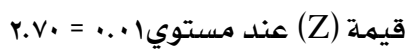

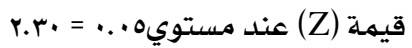

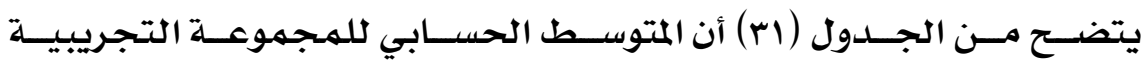

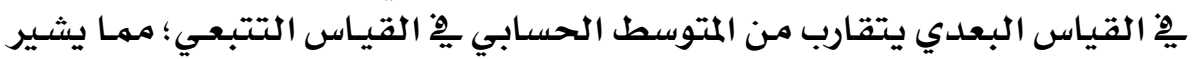

\section{$Y \otimes \Lambda$}


العكد التزاسع والخمسول ..الجزء الثمانىى.. هارس ..

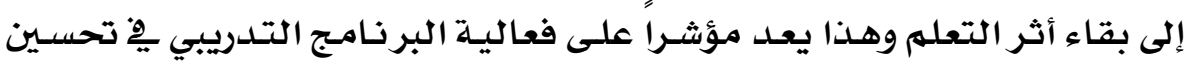

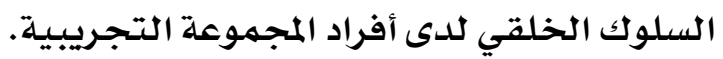

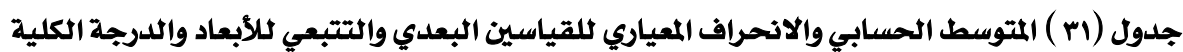

\begin{tabular}{|c|c|c|c|c|}
\hline \multicolumn{2}{|c|}{ التتبعى } & \multicolumn{2}{|c|}{ بعدي } & \multirow{2}{*}{ السلوك أبعاد الخلقىى } \\
\hline الانحراف المعيـاري & المتوسط & الانحراف المعياري & المتوسط & \\
\hline$\because$. vo & ro.Ar &. Vo & ro.17 & الصدق \\
\hline 1.0. & ro.r & 1.7 & Yะ.7T & التعاون \\
\hline $1 .+r$ & ro.r & 1.7 & Y0.77 & الصبر \\
\hline$\cdot . \wedge r$ & Y0.77 & 1.17 & r\&.Ar & الأمـانة \\
\hline $1 . \varepsilon V$ & r\&.Ar & 1.7. & ro.Ar & الإيثار \\
\hline$\varepsilon . r \varepsilon$ & Irv... & צ.or & 177.17 & الدرجـة الكلية \\
\hline
\end{tabular}

جدول ( Yr ) قيمة (Z) ) معرفة الفروق بين القياسين البعدي والتتبعي لأبعاد التفاؤل / التشاؤ

\begin{tabular}{|c|c|c|c|c|c|c|}
\hline مستوى الدلالة & قيمة Z & مجرتوع & متوسط الرتب & العدد & الرتب & التفاؤل / التعاد التشاؤم \\
\hline \multirow{4}{*}{ 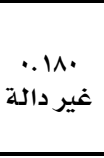 } & \multirow{4}{*}{$1 . r \leqslant Y-$} & r... & r... & $\cdot$ & الرتب السـالبية & \multirow{4}{*}{ الإقبـال على الحيـاة/ عدم الإحياة } \\
\hline & & Ir... & r... & $\varepsilon$ & الرتب الموجبية & \\
\hline & & & & 1 & التسـاوى & \\
\hline & & & & 7 & المحجموع & \\
\hline \multirow{4}{*}{ غير دالتة } & \multirow{4}{*}{$1 . \cdots-$} & r.o. & r.o. & 1 & الرتب السـالبـة & \multirow{4}{*}{ الثقة بـالنفس/ عدم الثقة } \\
\hline & & V.o. & Y.O. & $r$ & الرتب الموجبية & \\
\hline & & & & $r$ & التسـاوي & \\
\hline & & & & 7 & المجموع & \\
\hline \multirow{4}{*}{ غير دالة } & \multirow{4}{*}{$\because \leqslant \leqslant \vee-$} & $9 . \cdots$ & r... & $r$ & الرتب السـالبـة & \multirow{4}{*}{ بالشعور بالنجاح/ الشعور } \\
\hline & & 7. $\cdots$ & r... & $r$ & الرتب الموجبـة & \\
\hline & & & & 1 & التسـاوى & \\
\hline & & & & 7 & المجميوع & \\
\hline \multirow{4}{*}{ غير دالة } & \multirow{4}{*}{$\because \cdots$} & $0 . \cdots$ & r.o. & $r$ & الرتب السالبية & \multirow{4}{*}{ 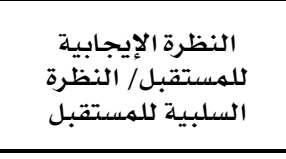 } \\
\hline & & $0 . \cdots$ & Y.0. & $r$ & الرتب الموجبـة & \\
\hline & & & & $r$ & التسـاوي & \\
\hline & & & & 7 & المجموع & \\
\hline \multirow{4}{*}{ غير دالة • غ • } & \multirow{4}{*}{$1 . r \varepsilon Y-$} & Ir... & r... & $\varepsilon$ & الرتب السـالبـة & \multirow{4}{*}{ /الاستسلامدي والانستحابرة } \\
\hline & & r... & r... & 1 & الرتب الموجبة & \\
\hline & & & & 1 & التسـاوى & \\
\hline & & & & 7 & المجموع & \\
\hline \multirow{4}{*}{ غير دالة } & \multirow{4}{*}{$\because Y V 7-$} & 7.0. & r. ro & $r$ & الرتب السـالبـة & \multirow{4}{*}{ الدرجـة الكليـة } \\
\hline & & 1.. 0. & r.Ar & $r$ & الرتب الموجبـة & \\
\hline & & & & 1 & التسـاوى & \\
\hline & & & & 7 & المججموع & \\
\hline
\end{tabular}

$$
\text { قيمة (Z) عند مستويه ... }
$$

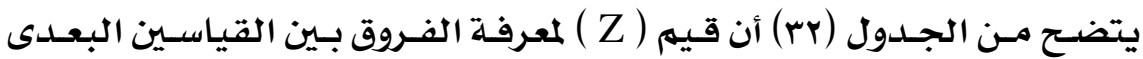

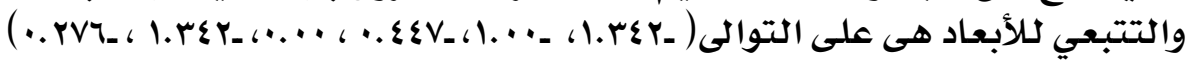

\section{Yoq}


العكد التزاسع والخمسول ..الجزء الثمانىى.. هارس ..

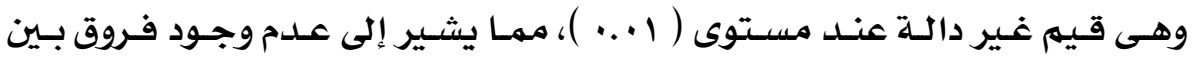

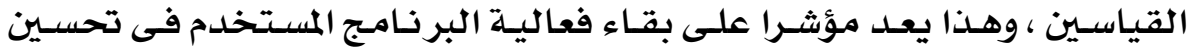

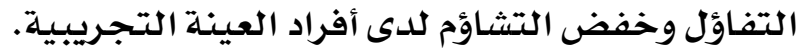

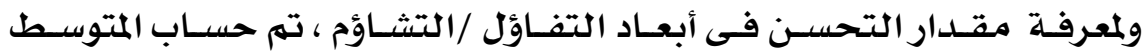

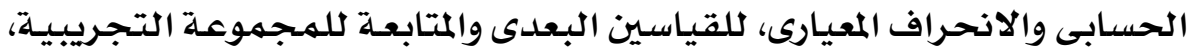
والجدول (rس) يوضح ذلك.

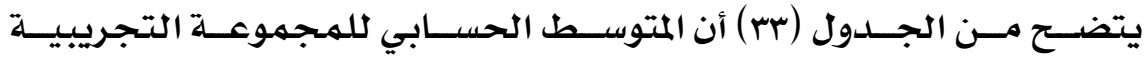

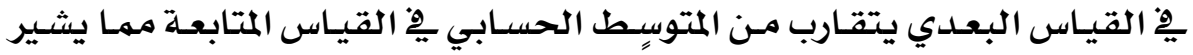

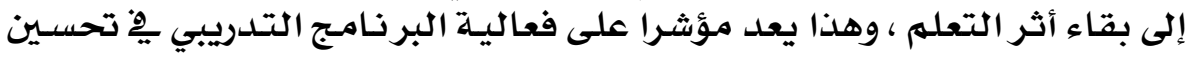

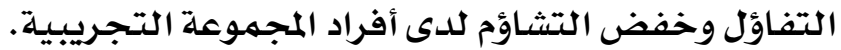
جدول (rr) المتوسط الحسابي والانحراف المعياري للقياسين البعدي والتتبعي للأبعاد والدرجة الكلية

\begin{tabular}{|c|c|c|c|c|}
\hline \multicolumn{2}{|l|}{ تتبعي } & \multicolumn{2}{|c|}{ بعدي } & \multirow{2}{*}{ التفاؤل / أبعاد التشاؤم } \\
\hline الانحراف المعياري & المتوسط & الانحراف المعياري & المتوسط & \\
\hline. .00 & Yะ.0. &. .19 & $r\{\ldots$ & الإقبال على الحياة/ عدم الإقبال على \\
\hline $1 . \mathrm{YI}$ & Y乏.TT & $1.7 \mathrm{r}$ & Y\&.rr & الثقة بالنفس/ عدم الثقة بالنفس \\
\hline$\therefore$ vo & YE.Ar &. .19 & ro... & بالشعور بـالنجحاح/ الشعور بالفشل \\
\hline .91 & Yะ. 17 & $\because$ vo & Yะ.17 & النظرة الإيجليبية للمستقبل اللمبل/ النظرة \\
\hline $1 . \S 1$ & r£... & 1.00 & $r \leqslant .0$. & التحدي والمثابرة / الاستسلام \\
\hline r. ¿ı & IYr.17 & $1 . \S 1$ & Irr... & الدرجة الكلية \\
\hline
\end{tabular}

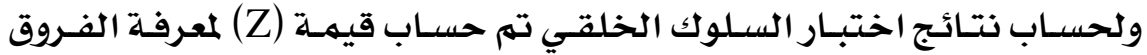

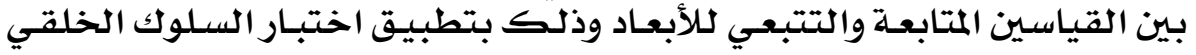

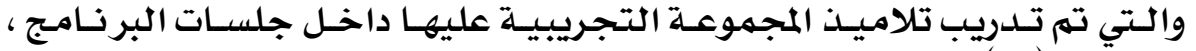

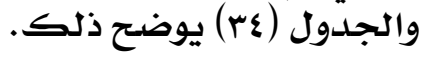

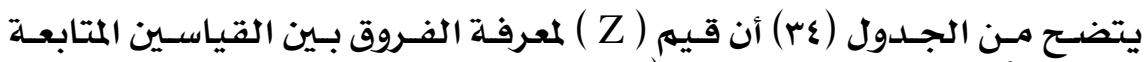

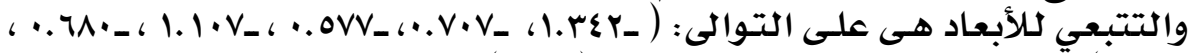

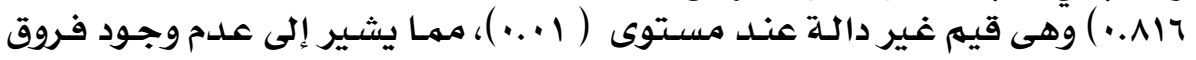

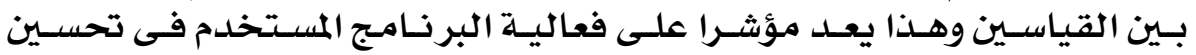

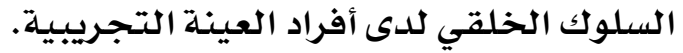

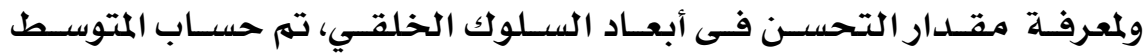

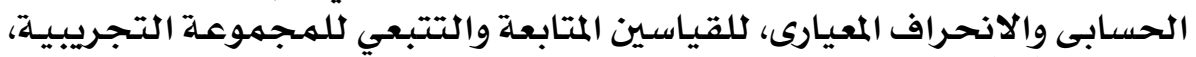
والجدول (مr) يوضح ذلابك.

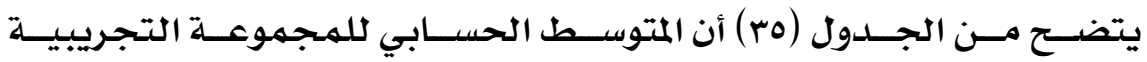

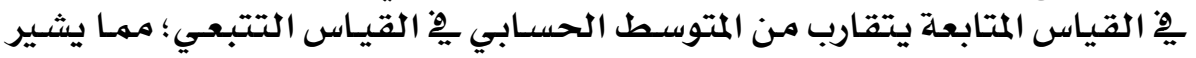

\section{Y7.}


العكد التزاسع والخمسول ..الجزء الثمانىى.. هارس ..

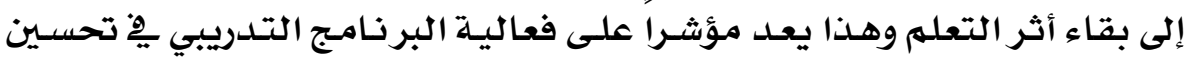

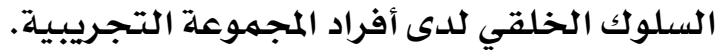

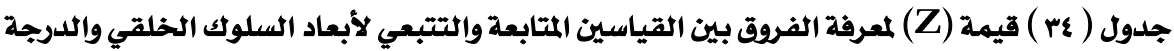
الكلية باستخدام معادلة ويلكوكسون

\begin{tabular}{|c|c|c|c|c|c|c|}
\hline مستوى & قيمة Z & مجمتوع & متوسط & العلدد & الرتب & السلوك الخبلقي \\
\hline \multirow{4}{*}{ غير دالة . • } & \multirow{4}{*}{$1 . r \leqslant r-$} & $1 Y . \cdot$. & r... & $\varepsilon$ & الرتب السالبة & \multirow{4}{*}{ الصدق } \\
\hline & & r... & r... & 1 & الرتب الموجبة & \\
\hline & & & & 1 & التسـاوي & \\
\hline & & & & 7 & المجمووع & \\
\hline \multirow{4}{*}{ غير دالة. } & \multirow{4}{*}{$\cdot v \cdot v-$} & $0 . .$. & Y.0. & $r$ & الرتب السالبة & \multirow{4}{*}{ التعاون } \\
\hline & & $1 \ldots$ & r.rr & $r$ & الرتب الموجبة & \\
\hline & & & & 1 & التسـاوي & \\
\hline & & & & 7 & المحمووع & \\
\hline \multirow{4}{*}{ غير دالة } & \multirow{4}{*}{$.0 \mathrm{VV}-$} & Y... & r... & 1 & الرتب السالبة & \multirow{4}{*}{ الصبر } \\
\hline & & $\varepsilon .$. & Y... & $r$ & الرتب الموجبـة & \\
\hline & & & & $r$ & التسـاوي & \\
\hline & & & & 1 & المحجموع & \\
\hline \multirow{4}{*}{ غير دالة 910.} & \multirow{4}{*}{$\because \cdot 1 \cdot v-$} & $11 . .$. & Y.Vo & $\varepsilon$ & الرتب السالبة & \multirow{4}{*}{ الأمانة } \\
\hline & & $1 \ldots$. & $0 . .$. & $r$ & الرتب الموحبـة & \\
\hline & & & & . & التسـاوي & \\
\hline & & & & 7 & المجميموع & \\
\hline \multirow{4}{*}{ غير دالة } & \multirow{4}{*}{$\cdot .71 \cdot-$} & $0 . .$. & Y.O. & $r$ & الرتب السالبة & \multirow{4}{*}{ الإيثار } \\
\hline & & $1 \ldots$. & $r . r r$ & $r$ & الرتب الموجبة & \\
\hline & & & & 1 & التسـاوي & \\
\hline & & & & 7 & المجميموع & \\
\hline \multirow{4}{*}{ غير دالة } & \multirow{4}{*}{$\cdot .117-$} & v... & r.o. & $r$ & الرتب السالبة & \multirow{4}{*}{ الدرجـة الكلية } \\
\hline & & $1 \xi \ldots$ & r.o. & $\varepsilon$ & الرتب المموجية & \\
\hline & & & & . & التسـاوي & \\
\hline & & & & 7 & المحموع & \\
\hline
\end{tabular}

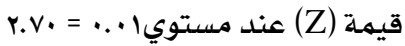

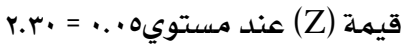

جلدول (مr ) المتوسط الحسابي والانحراف المعياري للقياسين المتابعة والتتبعي للأبعاد والدرجة الكلية

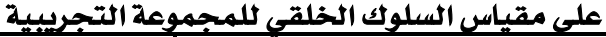

\begin{tabular}{|c|c|c|c|c|}
\hline \multicolumn{2}{|c|}{ المتابعة } & \multicolumn{2}{|c|}{ التتبعي } & \multirow{2}{*}{ السلوك أبعادلقي } \\
\hline الانحراف المعياري & المتوسط & الانحراف المعياري & المتوسط & \\
\hline $1 . . r$ & Yo.ru &. . vo & ro.Ar & الصدق \\
\hline$\cdot .117$ & Y0.77 & 1.0. & Yo.rr & التعاون \\
\hline $1.0 \varepsilon$ & Yo.0. & $1 . \cdot r$ & Yo.rr & الصير \\
\hline 1.rv & Yo.0. & $\cdot . \wedge r$ & $r 0.74$ & الأممانة \\
\hline 1.01 & Yo.ru & $1 . £ \mathrm{~V}$ & $r\{. \wedge r$ & الإيثار \\
\hline £.£० & IrV.rr & $\varepsilon . Y \xi$ & IYV... & الدرجة الكلية \\
\hline
\end{tabular}

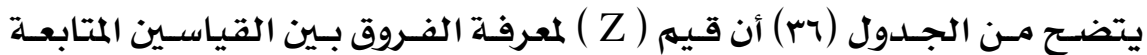

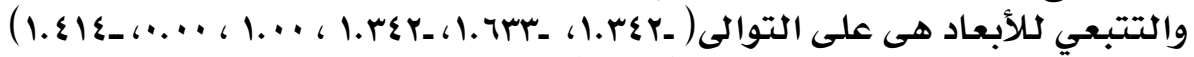

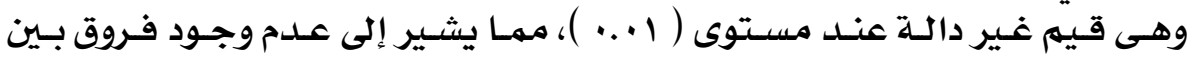

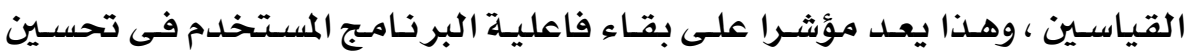

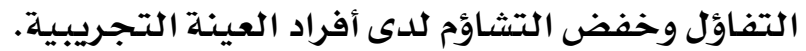

\section{Y71}




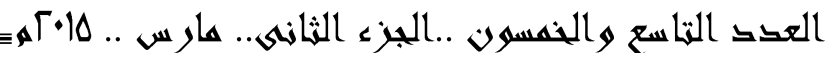

جدول (ه) قيمة (Z) لمعرفة الفروق بين القياسين المتابعة والتتبعي لأبعاد التفاؤل /التشاؤم والدرجة

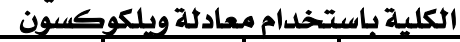

\begin{tabular}{|c|c|c|c|c|c|c|}
\hline مستوى الدلالة & قيمة Z & مجرتوع & متوسط الرتب & العدد & الرتب & 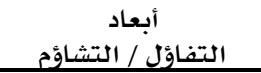 \\
\hline \multirow{4}{*}{ غير دالة • • } & \multirow{4}{*}{$1 . r \leqslant Y-$} & r... & r... & 1 & الرتب السالبـة & \multirow{4}{*}{ عدم الإقبال على الحيال على الحياة/ } \\
\hline & & 1r... & r... & $\varepsilon$ & الرتب الموجبـة & \\
\hline & & & & 1 & التسـاوى & \\
\hline & & & & 7 & المحموع & \\
\hline \multirow{4}{*}{ غير دالة } & \multirow{4}{*}{ 1.Tr- } & r.o. & r.o. & 1 & الرتب السـالبـة & \multirow{4}{*}{ الثقة بالنفس/ الثـفس عدم } \\
\hline & & IV.0. & r.o. & 0 & الرتب الموجبـة & \\
\hline & & & & . & التسـاوى & \\
\hline & & & & 7 & المجمهوع & \\
\hline \multirow{4}{*}{ غير دالة • • } & \multirow{4}{*}{$1 . r \varepsilon r-$} & Ir... & r... & $\varepsilon$ & الرتب السالبة & \multirow{4}{*}{ بالشعور بالنجاح/ الشعالفل } \\
\hline & & r... & r... & 1 & الرتب الموجبـة & \\
\hline & & & & 1 & التسـاوى & \\
\hline & & & & 7 & المجمموع & \\
\hline \multirow{4}{*}{ غير دالة } & \multirow{4}{*}{$1 . \cdots$} & 7... & 7. . . & 1 & الرتب السـالبـة & \multirow{4}{*}{ للمستقبل النظرة الإيجابية النظرة } \\
\hline & & $10 . \ldots$ & r... & 0 & الرتب الموجبـة & \\
\hline & & & & + & التسـاوي & \\
\hline & & & & 7 & المجموع & \\
\hline \multirow{4}{*}{ غير دالة } & \multirow{4}{*}{$\because \cdots$} & $0 . \cdots$ & Y.O. & $r$ & الرتب السـالبـة & \multirow{4}{*}{ /الاستسـلام والانسـحساب والمثابرة } \\
\hline & & $0 . \cdots$ & Y.0. & $r$ & الرتب الموجبـة & \\
\hline & & & & $r$ & التسـاوى & \\
\hline & & & & 7 & المحموع & \\
\hline \multirow{4}{*}{ غير دالة } & \multirow{4}{*}{$1 . \varepsilon 1 \leqslant-$} & r.o. & Y.o. & 1 & الرتب السالبـة & \multirow{4}{*}{ الدرجـة الكلية } \\
\hline & & r.lr & r.lr & $\varepsilon$ & الرتب الموجبـة & \\
\hline & & & & 1 & التسـاوى & \\
\hline & & & & 7 & المجموع & \\
\hline
\end{tabular}

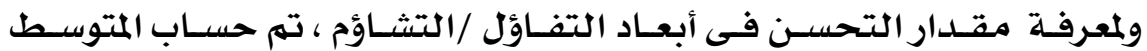

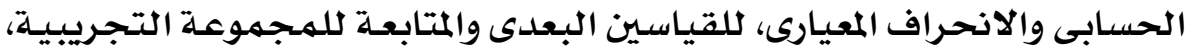

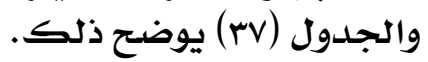

جلدول (rV) المتوسط الحسابي والانحراف المعياري للقياسين المتابعة والتتبعي للأبعاد والدرجة الكيادية الكلية

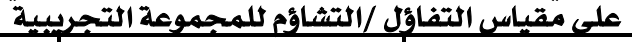

\begin{tabular}{|c|c|c|c|c|}
\hline \multicolumn{2}{|c|}{ 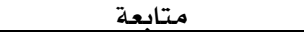 } & \multicolumn{2}{|l|}{ تتبعي } & \multirow{2}{*}{ التفاؤل / البعاد التشاؤم } \\
\hline الانحراف المعيـاري & المتوسط & الانحراف المعيـاري & المتتوسط & \\
\hline. .19 & ro... &. .00 & Y $\leqslant .0$. & الإقبال على الحياة/ عدم الإقبال على الحياة \\
\hline $1 .+r$ & ro.rr & $1 . \mathrm{YI}$ & Y\$.77 & الثقة بالنفس/ عدم الثقة بالنفس \\
\hline .017 & $r \varepsilon . r r$ &.. vo & $r \varepsilon . \wedge r$ & بالشعور بالنجاح/ الشعور بالفشل \\
\hline .017 & $r \leqslant .74$ &. .91 & Y\$.17 & النظرة الإيجابية للمستقبل/ النظرة السلبية \\
\hline $1 . Y 7$ & $r\{\ldots$ & $1 . \$ 1$ & $r\{\ldots$ & التحدي والمثابرة /الاستسلاموالانسحاب \\
\hline Y.M & IYr.r & Y.\&A & IYr.19 & الدرجة الكلية \\
\hline
\end{tabular}

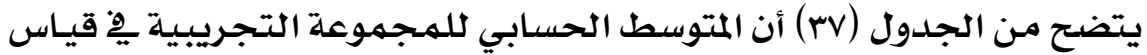

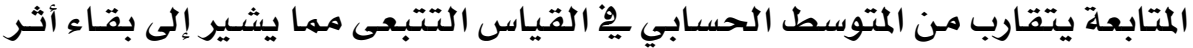

\section{YTr}


العكد التزاسع والخمسول ..الجزء الثخانىى.. هارس ..

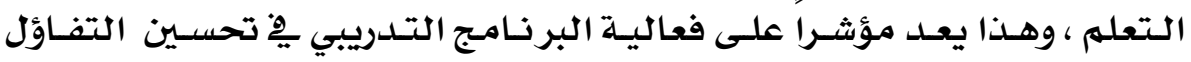

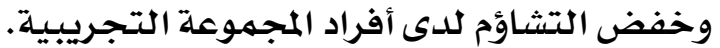

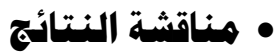

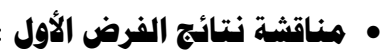

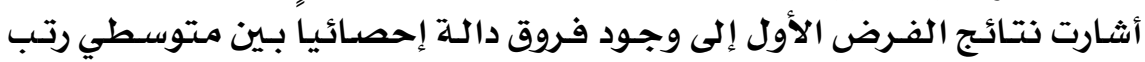

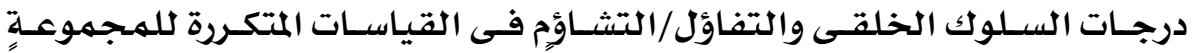

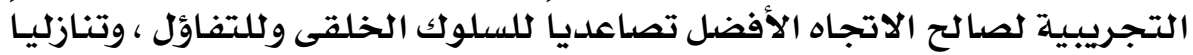

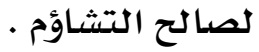

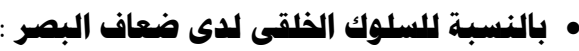

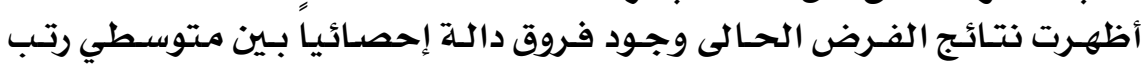

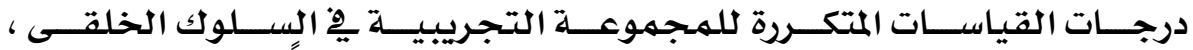

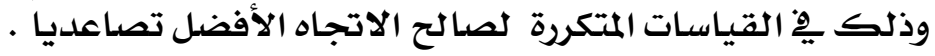

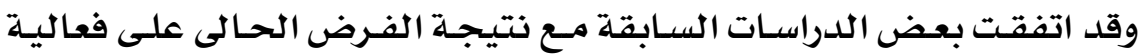

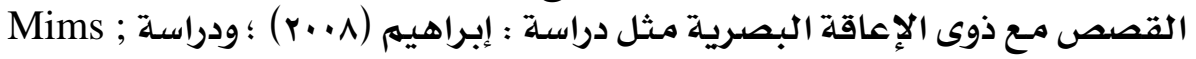
Tadić ; Pring \& Dale ودراسـة (2009) : Browder; Baker; Lee \& Spooner (2013) . Rusko et al.(2014) (2013) ، ودراسـة (2009)

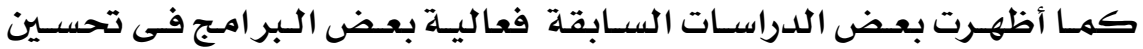

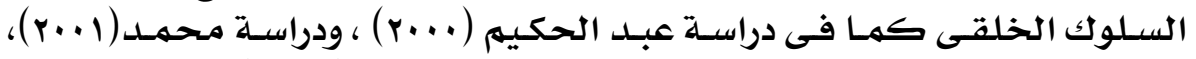

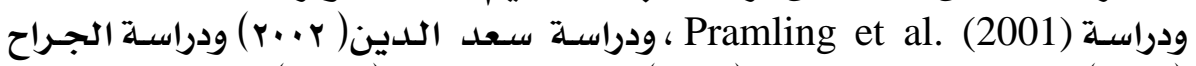

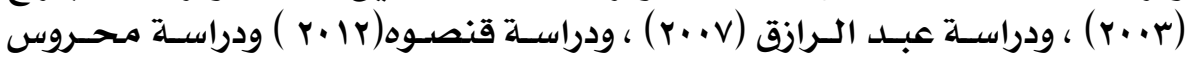

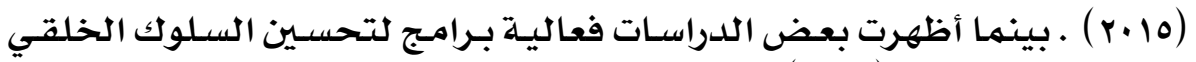

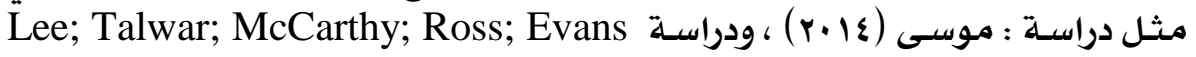
.\& Arruda (2014)

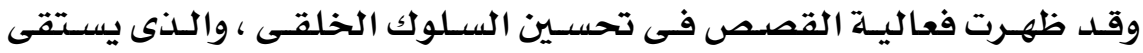

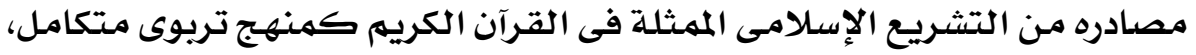

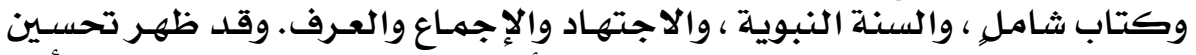

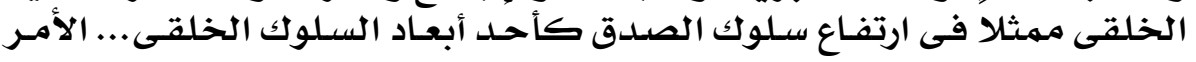

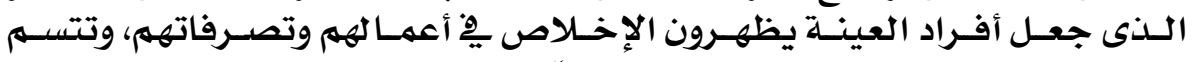

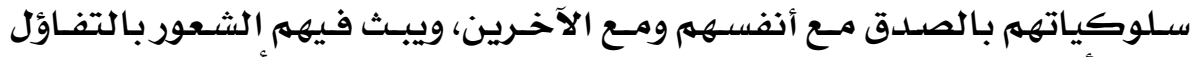

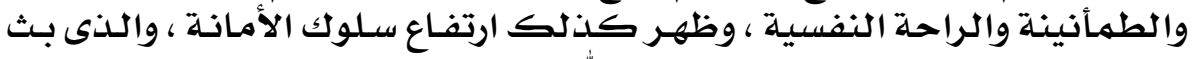

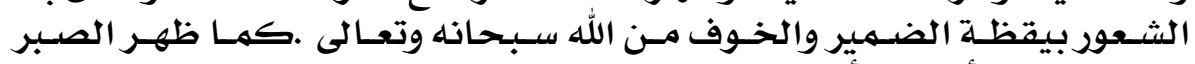

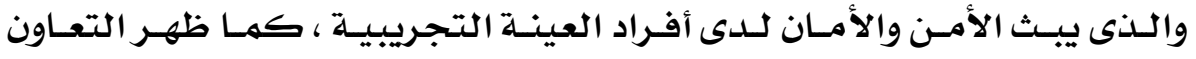

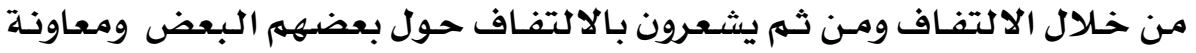

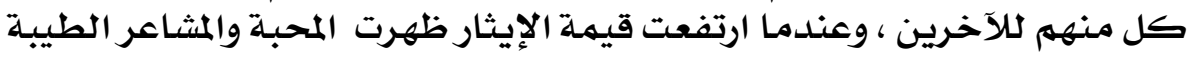

\section{Y Y}


العكد التزاسع والخمسول ..الجزء الثخانىى.. هارس ..

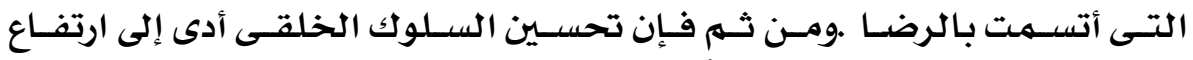

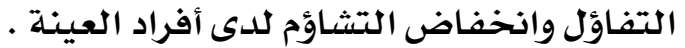

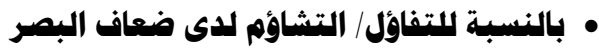

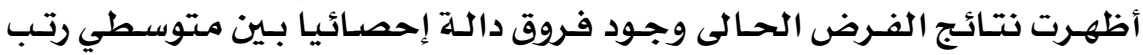

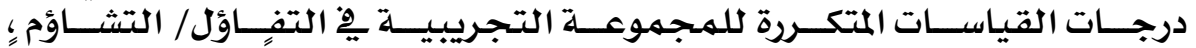

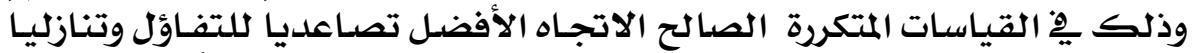

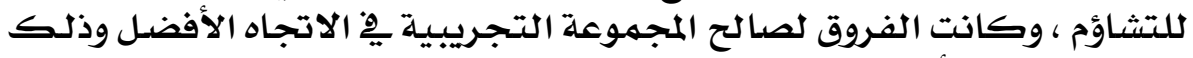

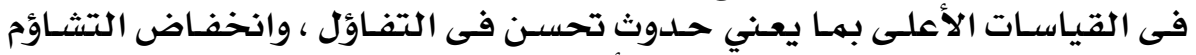

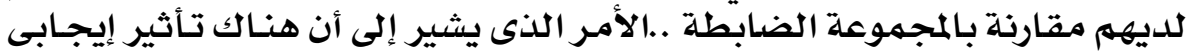

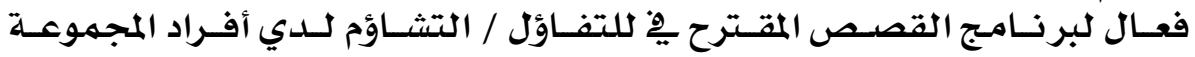
التجريبية.

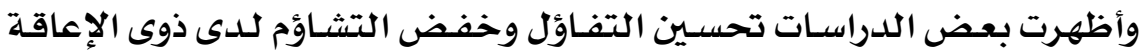

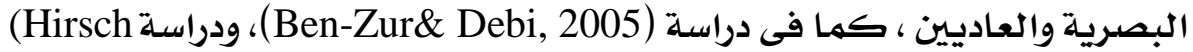

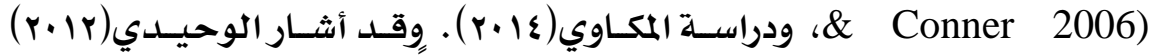

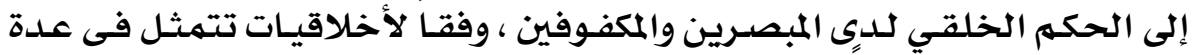

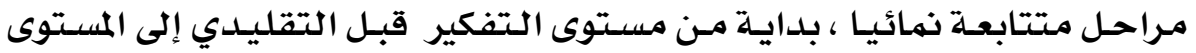

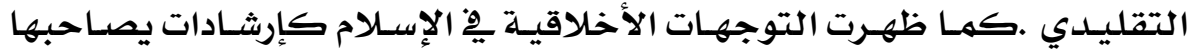

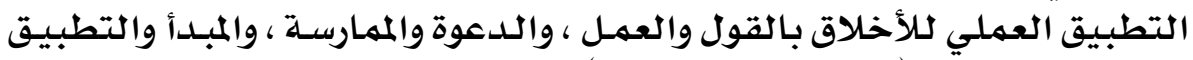

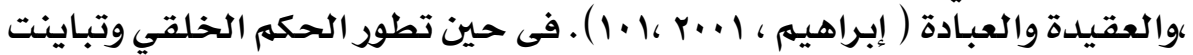

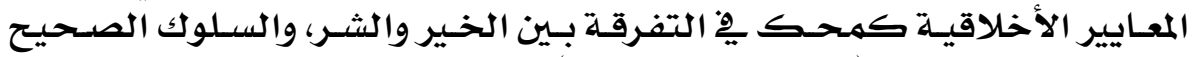

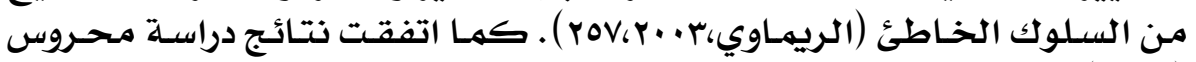

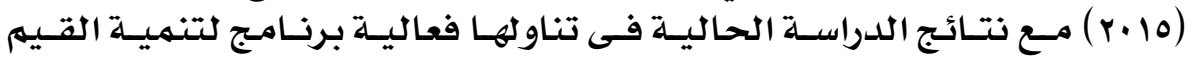

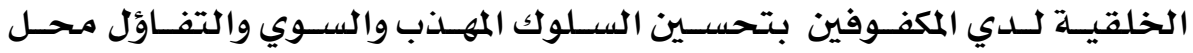

التشاؤم.

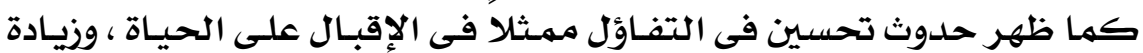

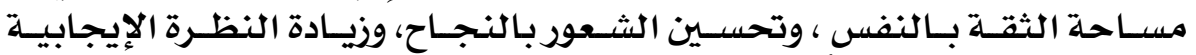

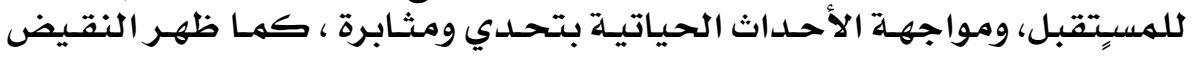

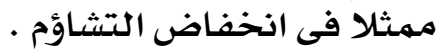

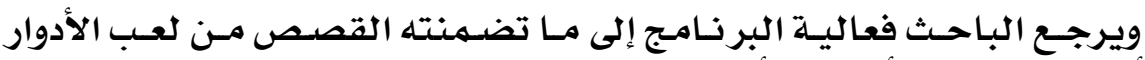

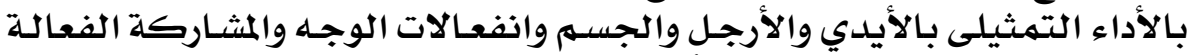

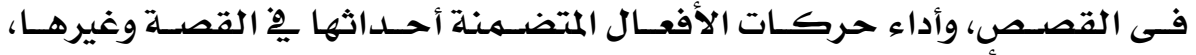

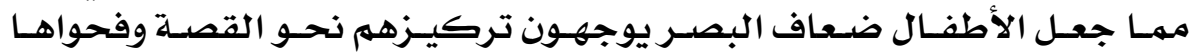

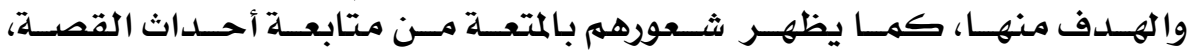

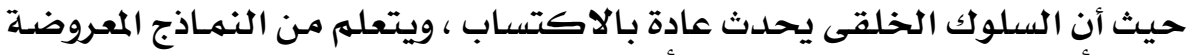

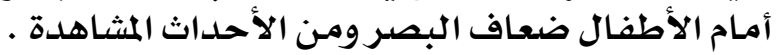

\section{Y78}


العكد التزاسع والخمسول ..الجزء الثخانىى.. هارس ..

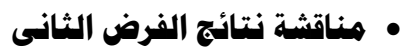

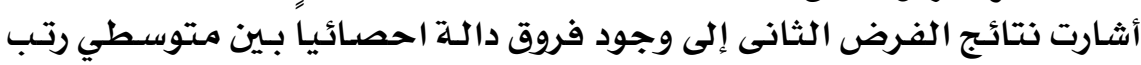

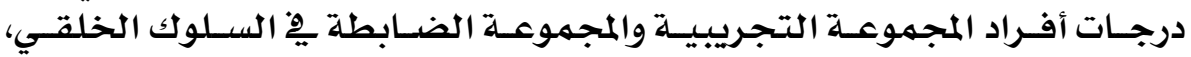

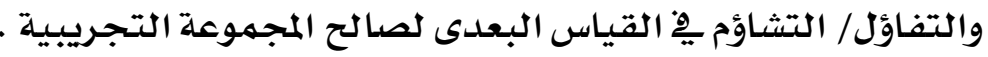

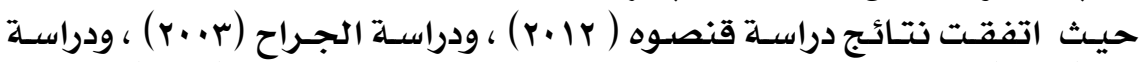

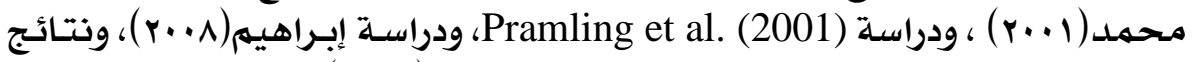

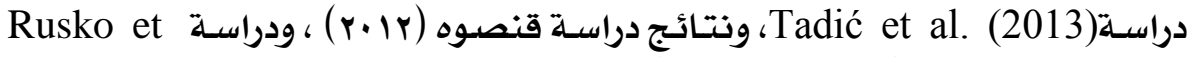

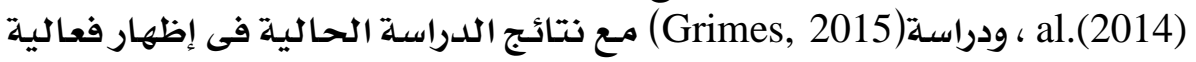

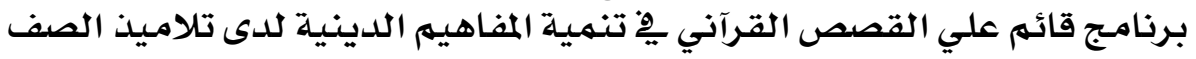

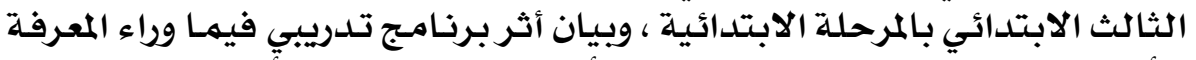

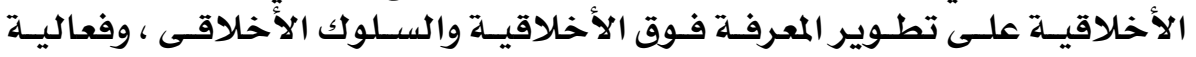

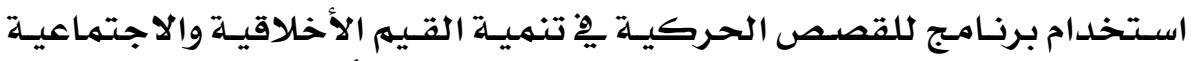

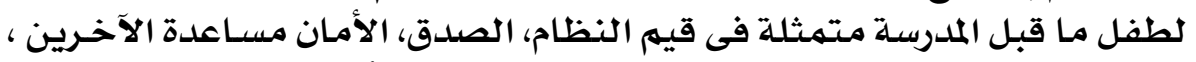

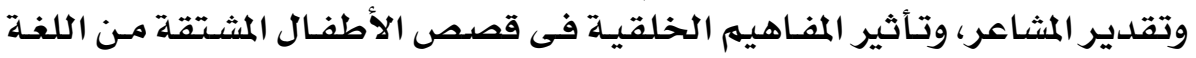

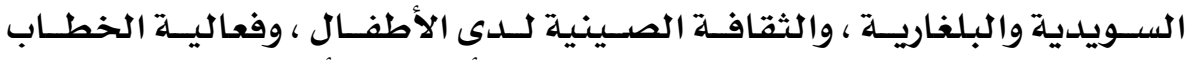

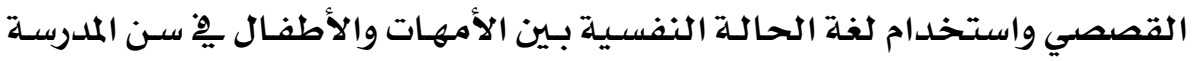

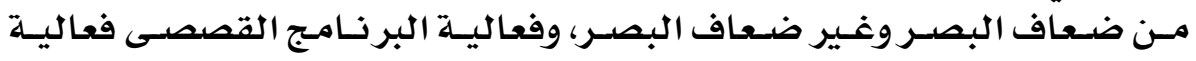

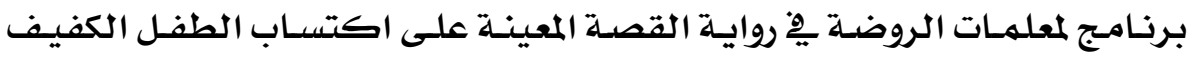

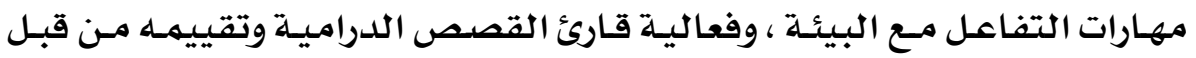

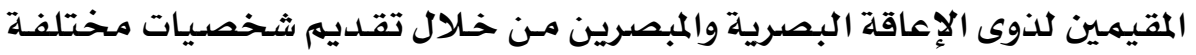

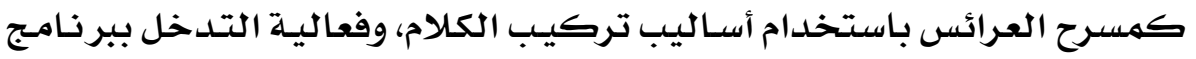

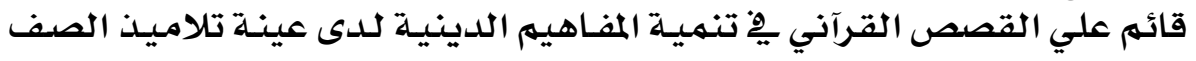
الثالث الابتدائي.

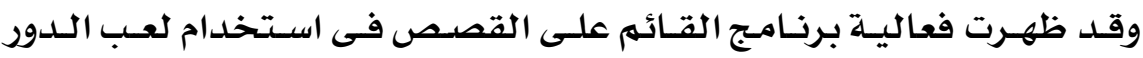

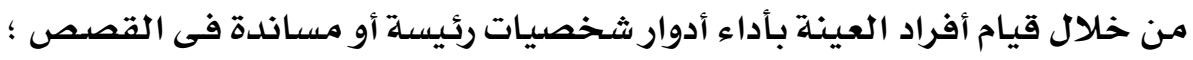

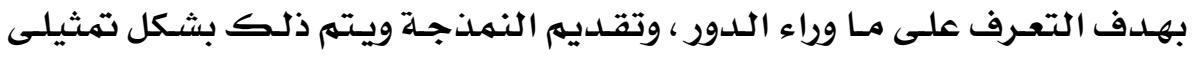

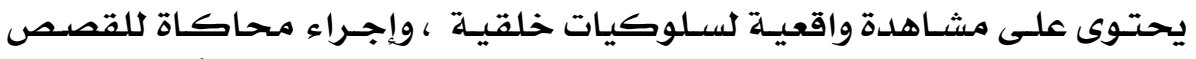

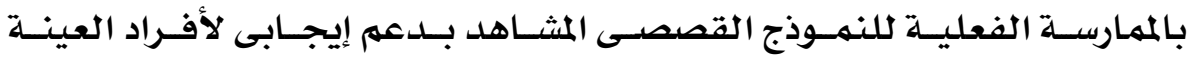

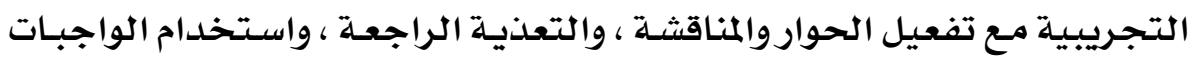

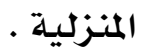

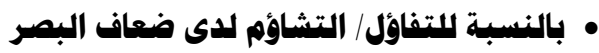

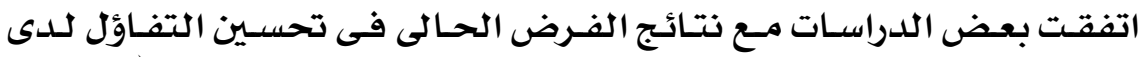

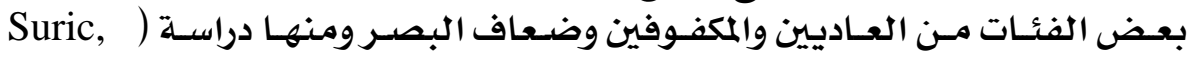

\section{Y70}


العكد التزاسع والخمسول ..الجزء الثخانىى.. هارس ..

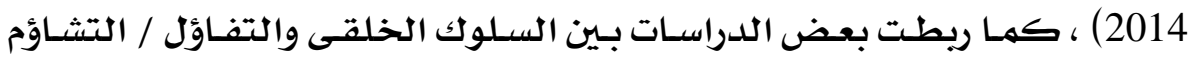

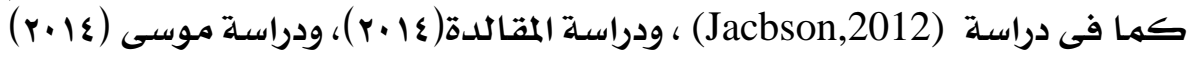

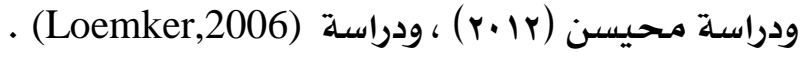

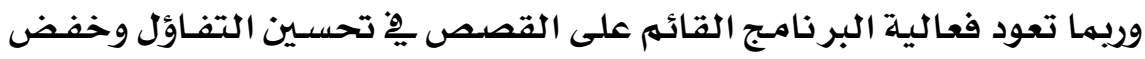

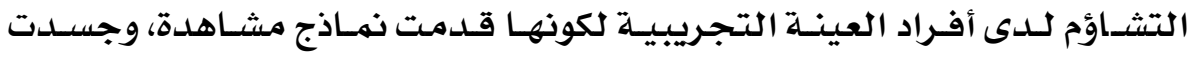

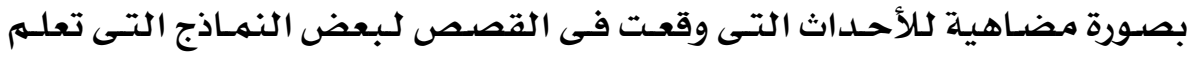

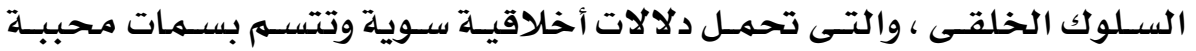

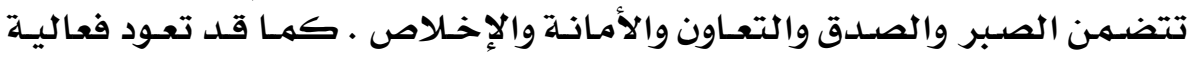

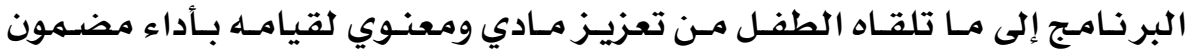

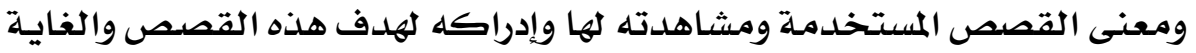
من ورائها المنائ.

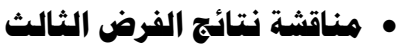

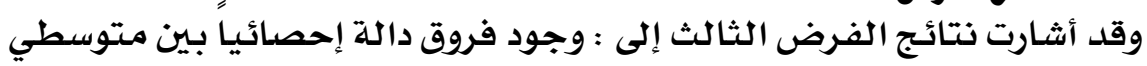

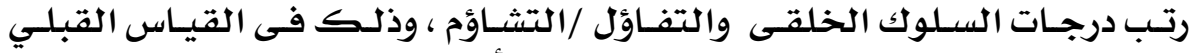

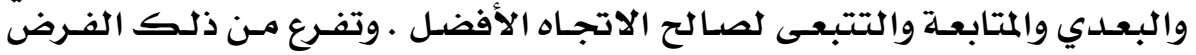
النتائج التالية : المبتابع

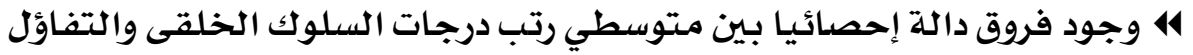

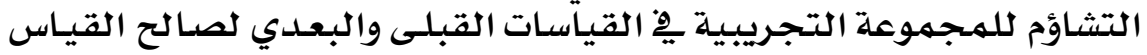

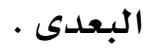

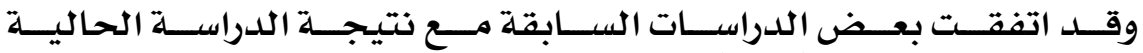

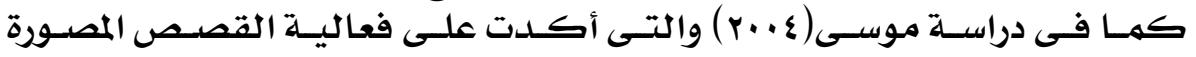

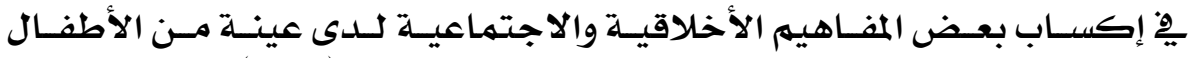

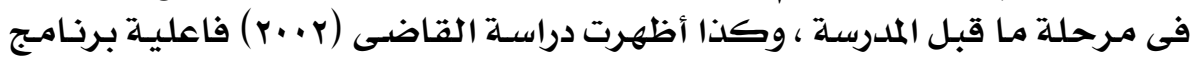

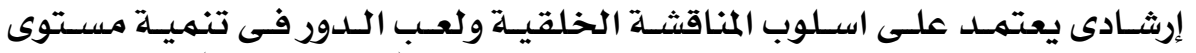

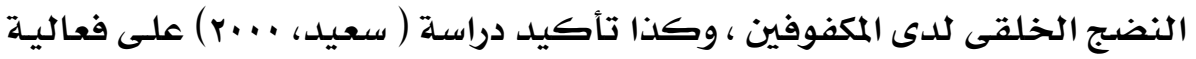

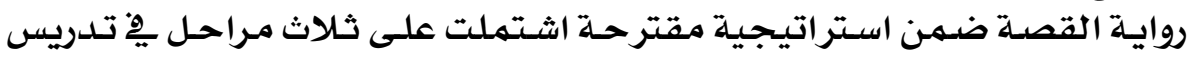

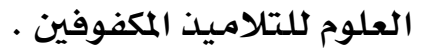

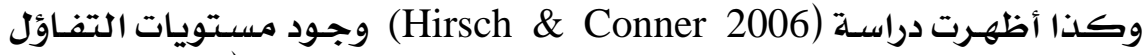

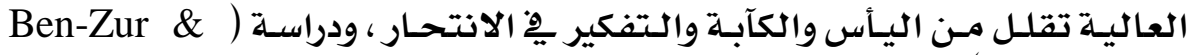

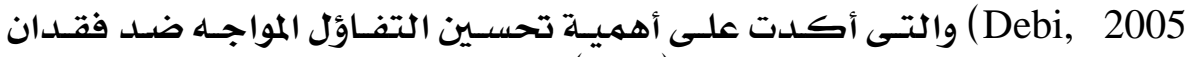

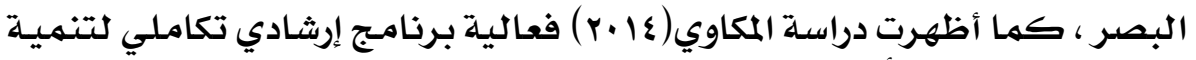

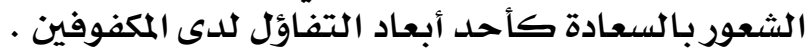

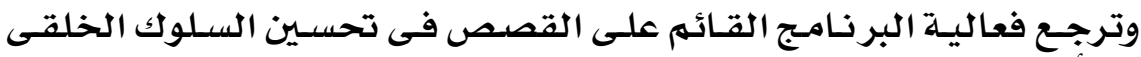

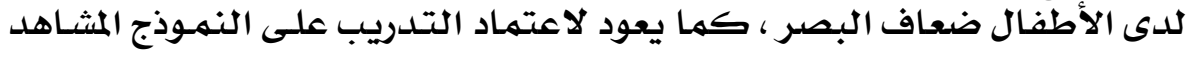

\section{7}




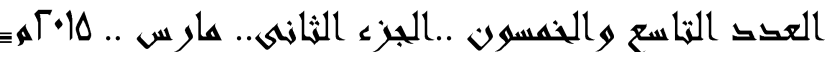

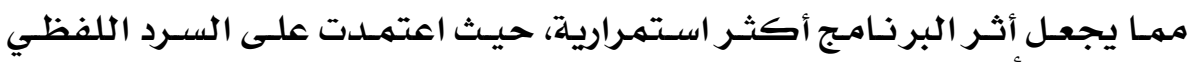

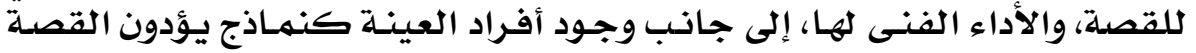

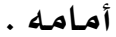

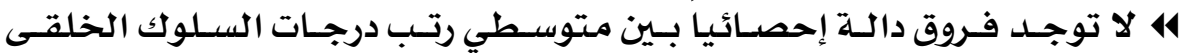

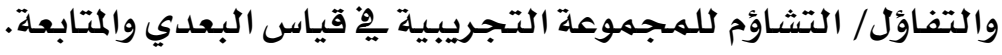

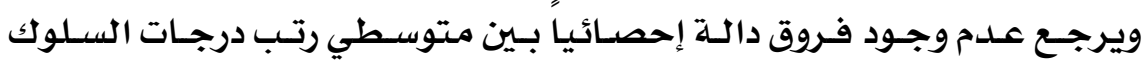

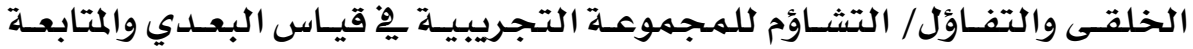

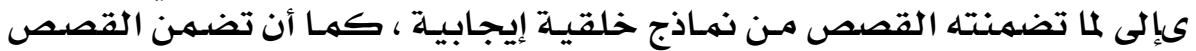

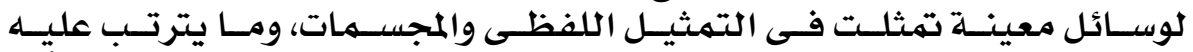

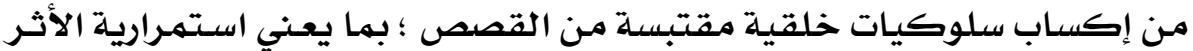

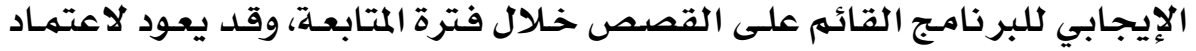

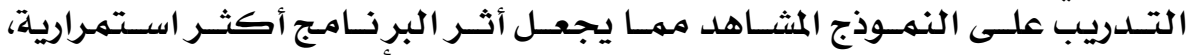

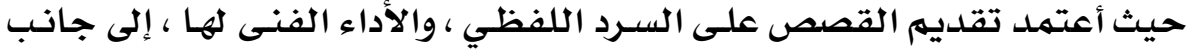

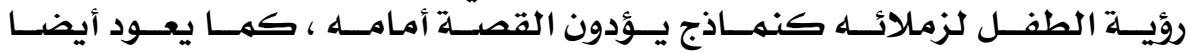

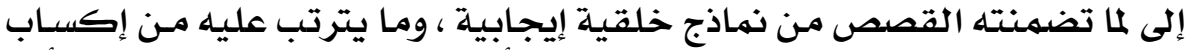

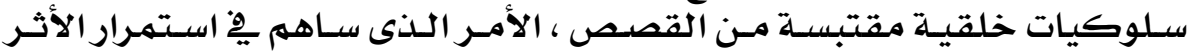
الإيجابي للبر نامـج.

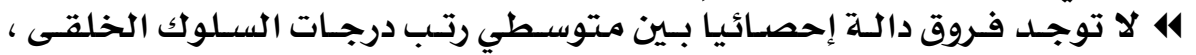

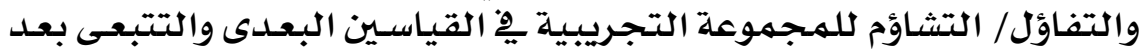

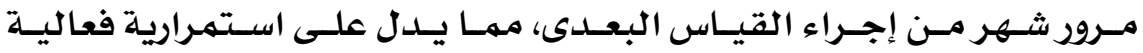

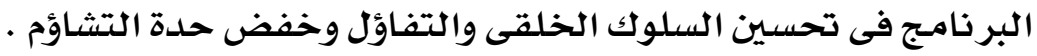

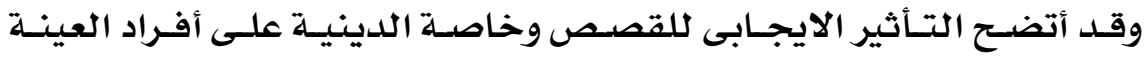

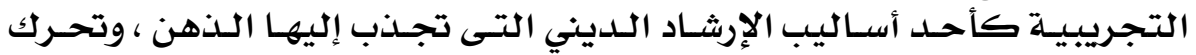

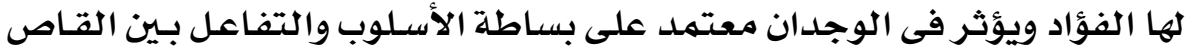

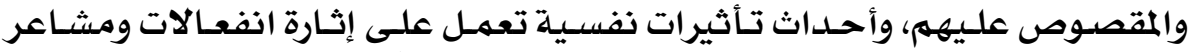

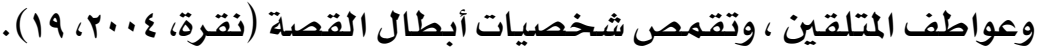

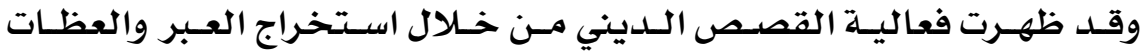

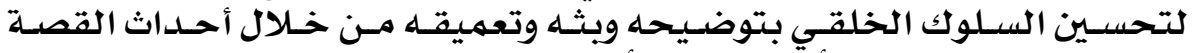

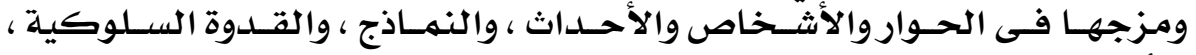

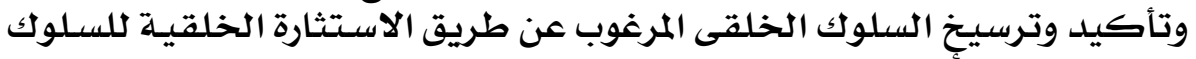

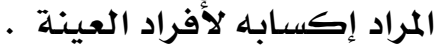

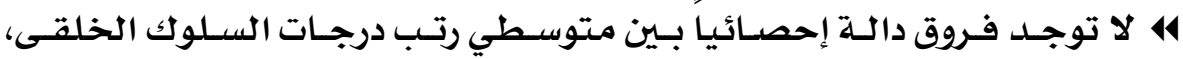

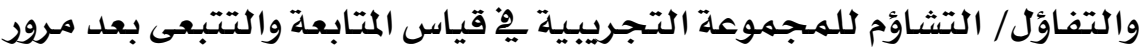

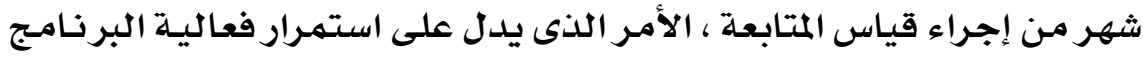

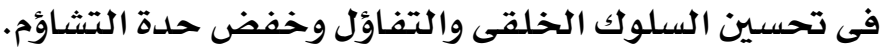

\section{YTV}


العكد التزاسع والخمسول ..الجزء الثخانىى.. هارس ..

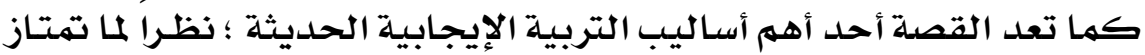

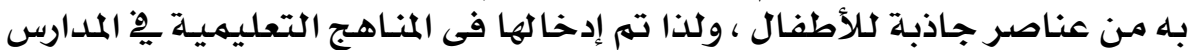

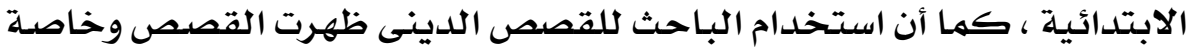

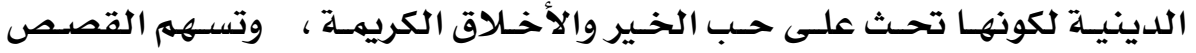

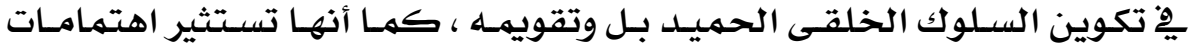

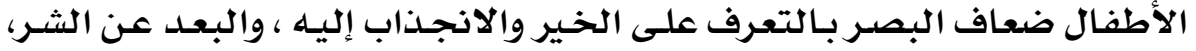

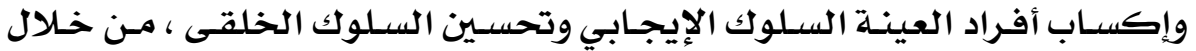

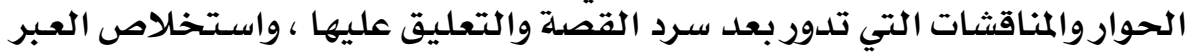
والعظات منها مواقهات

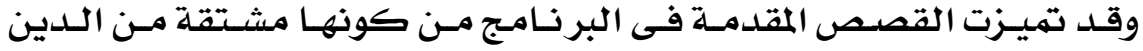

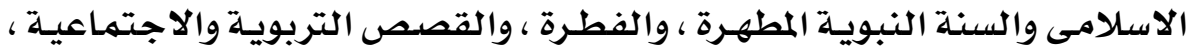

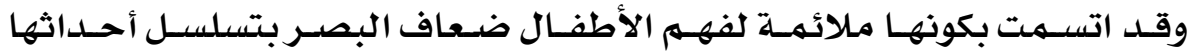

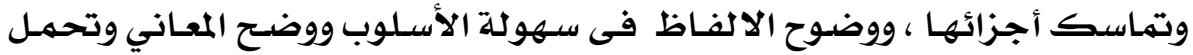

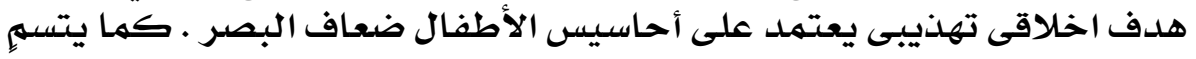

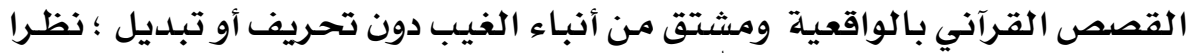

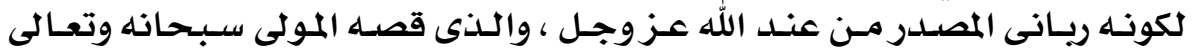

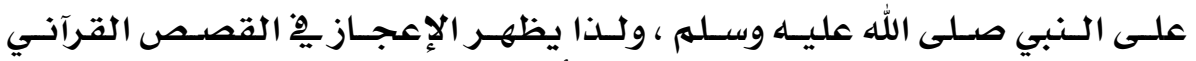

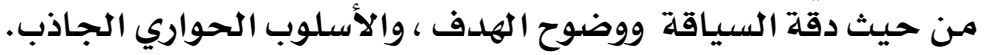

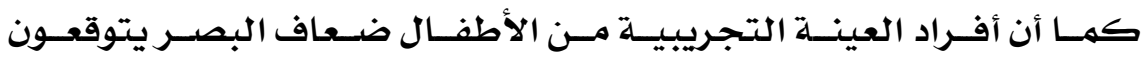

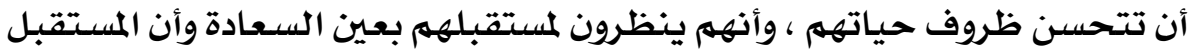

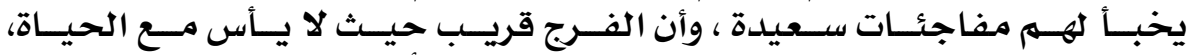

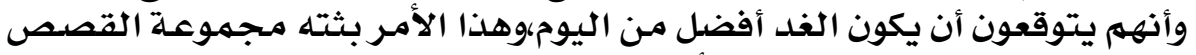

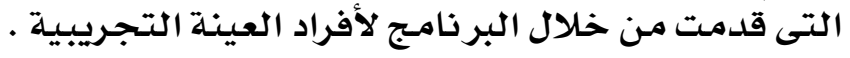

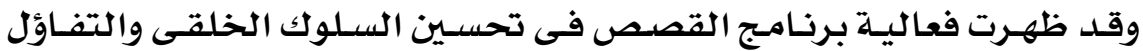

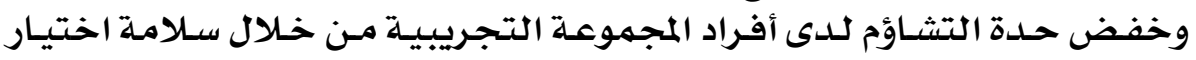

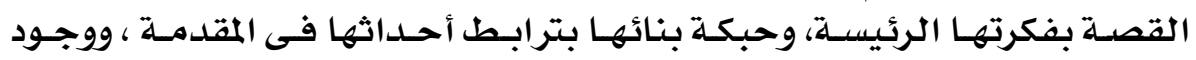

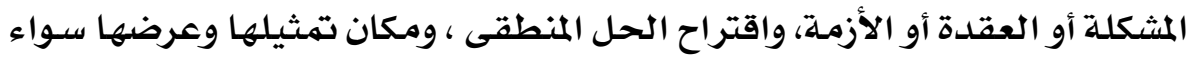

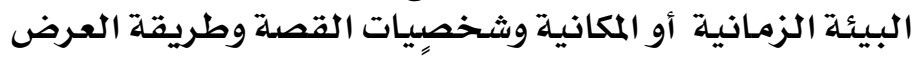

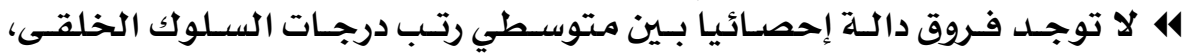

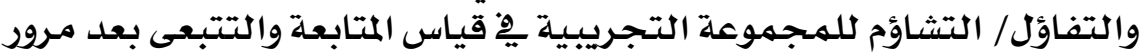

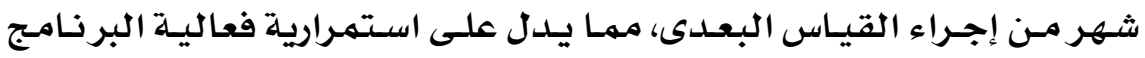

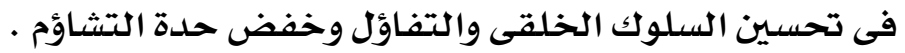

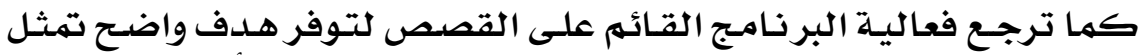

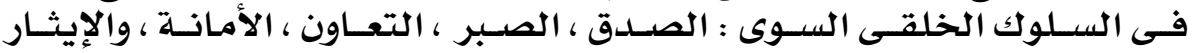

\section{YฯА}


العكد التزاسع والخمسول ..الجزء الثخانىى.. هارس ..

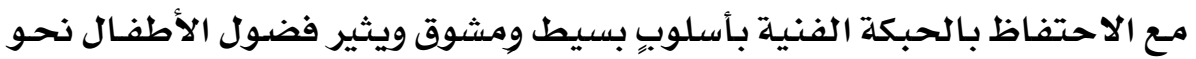

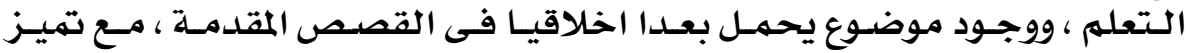

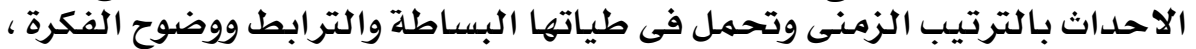

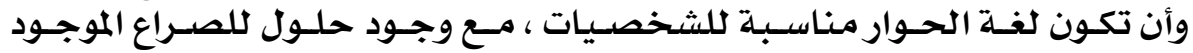

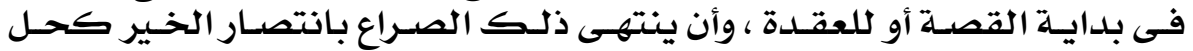

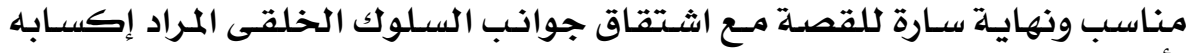

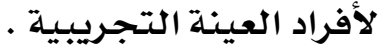

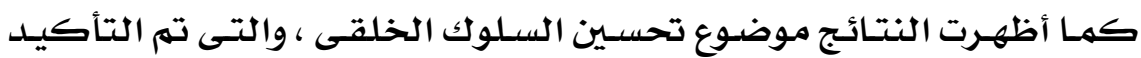

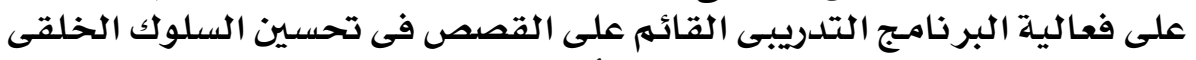

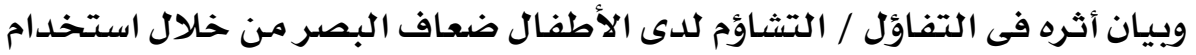

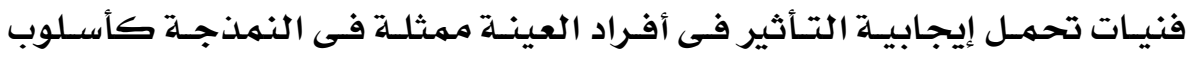

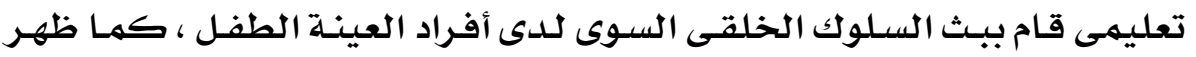

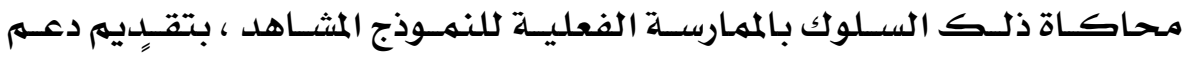

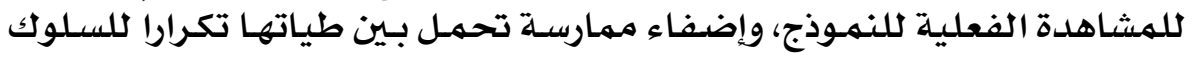

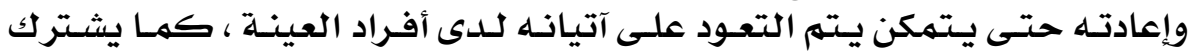

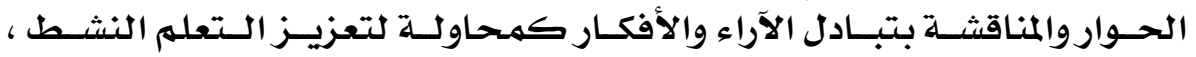

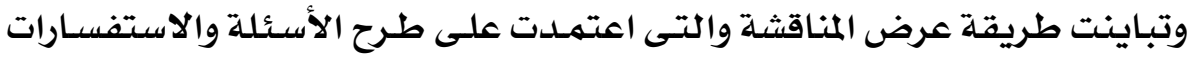

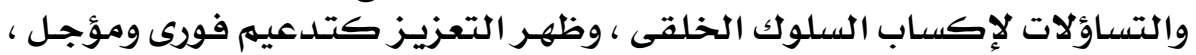

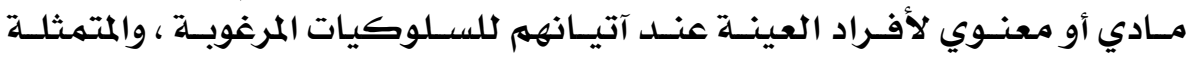

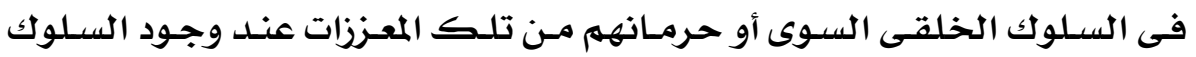

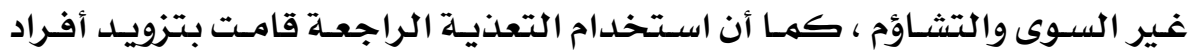

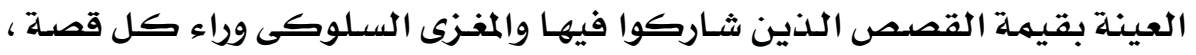

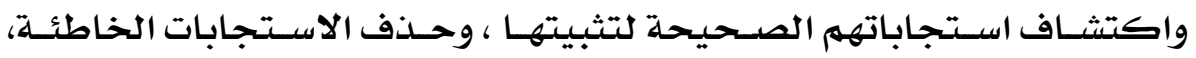

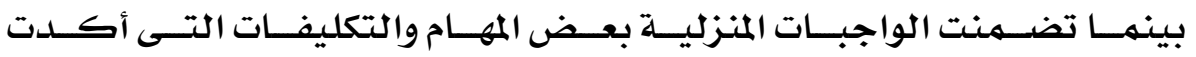

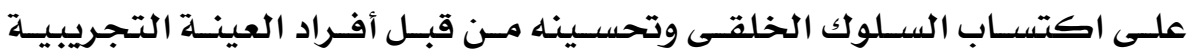
بالتدريب عليها في المنزل.

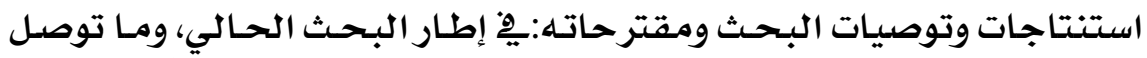

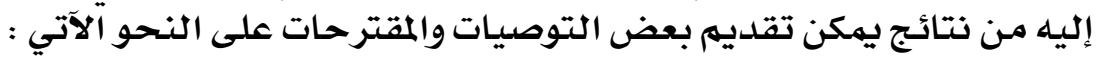

\section{• الاستنتاجات :}

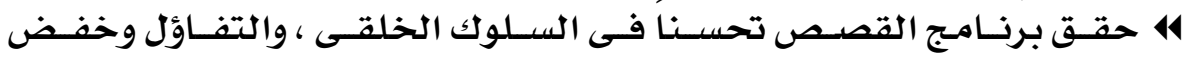

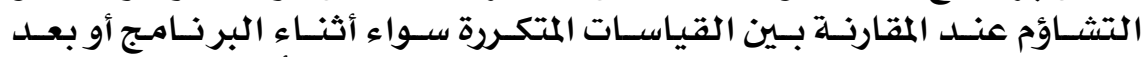

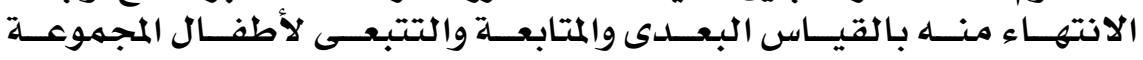

$$
\text { التجريبية. }
$$

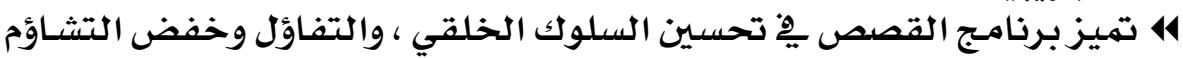

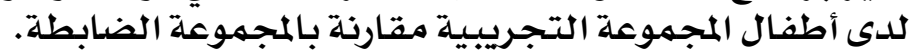

\section{9}




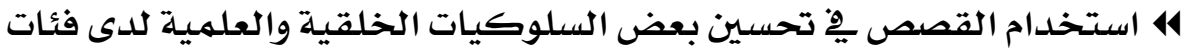

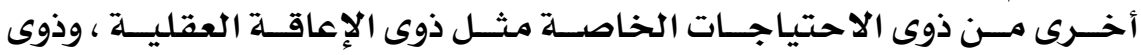

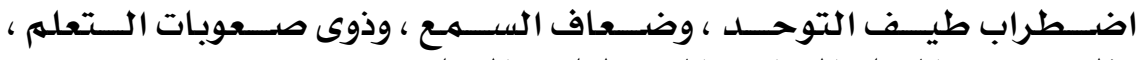

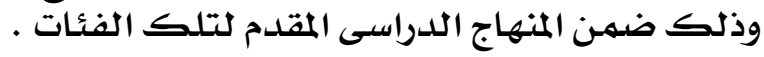

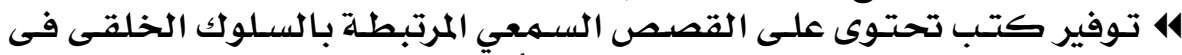

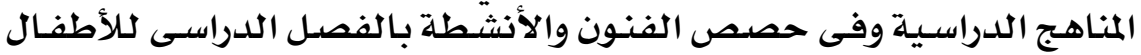

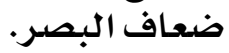

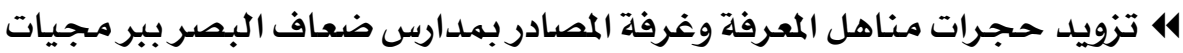

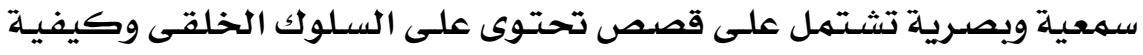

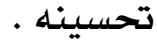

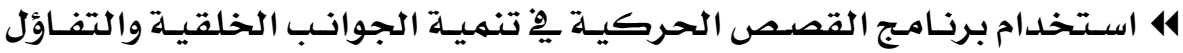

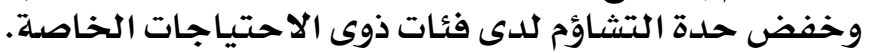

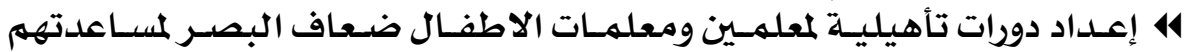

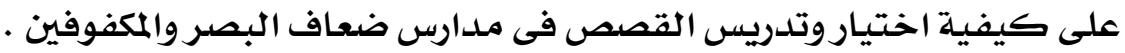

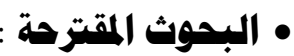

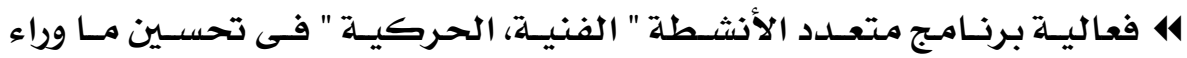

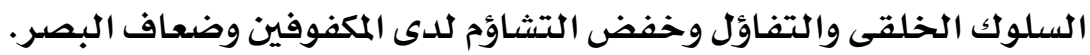

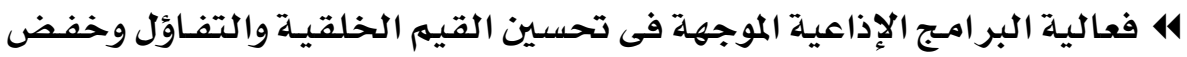

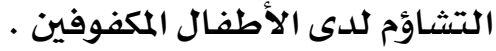

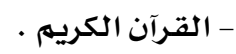

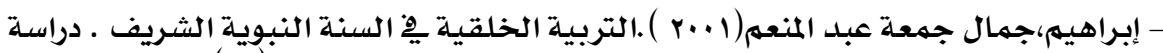

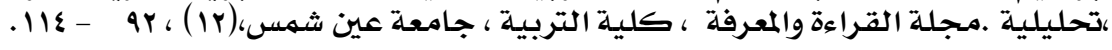

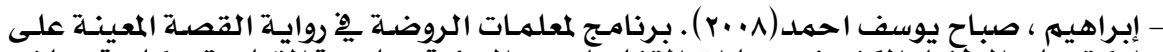

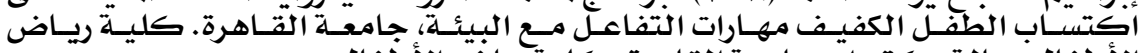

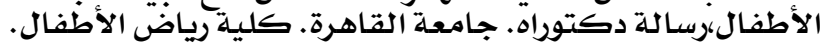

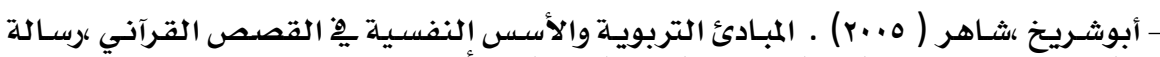

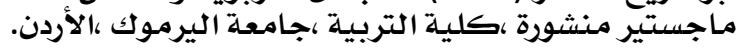

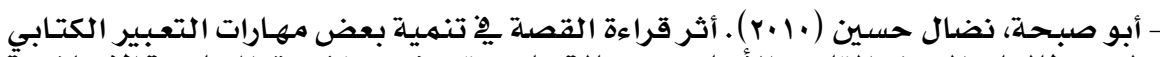

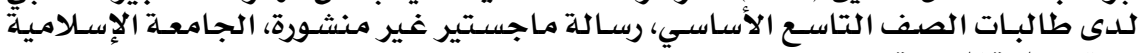
بغزة، كلية التربية.

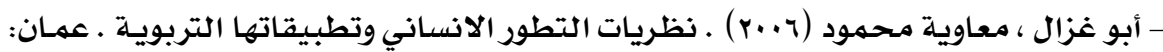

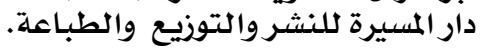

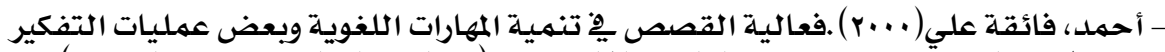

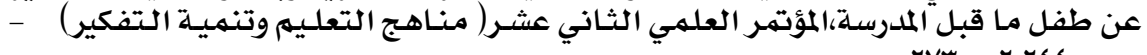

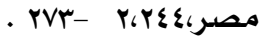

\section{YV.}




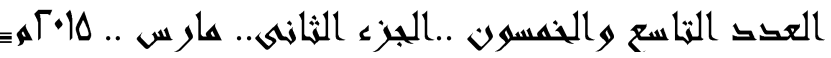

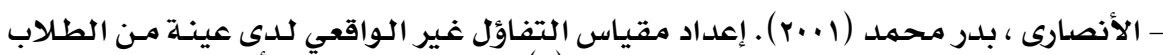

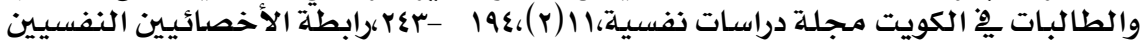
المصرية،مصرباته

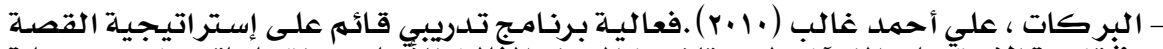

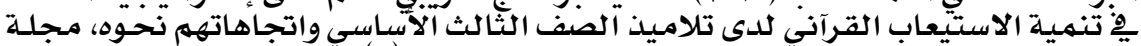

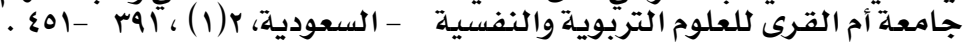

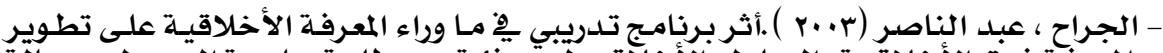

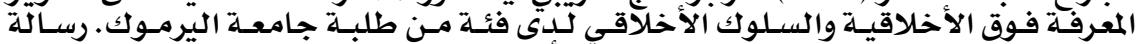

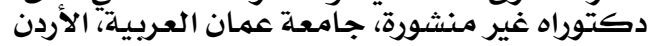

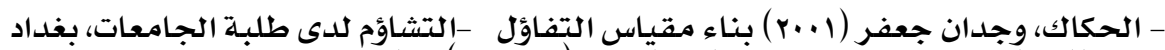

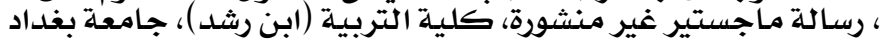

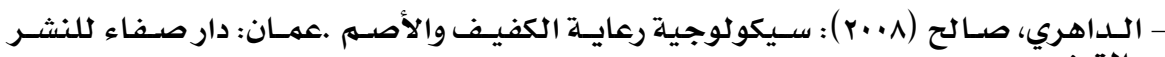
والتوزيـع.

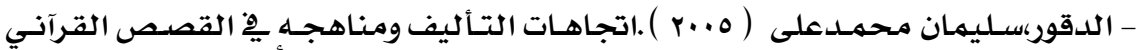

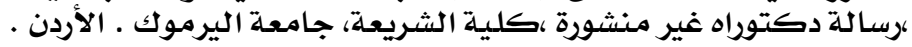

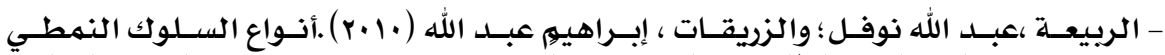

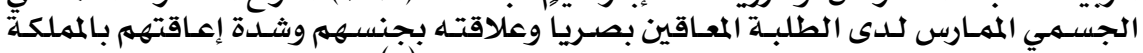

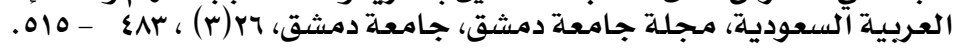

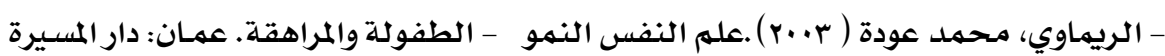

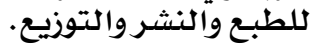

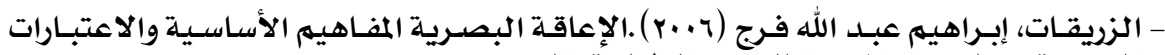

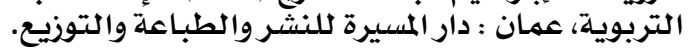

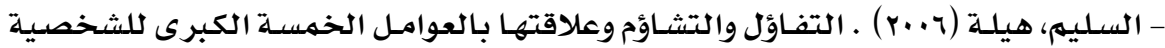

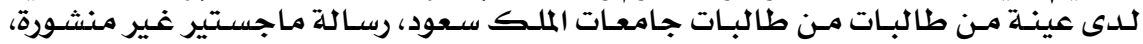

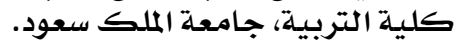

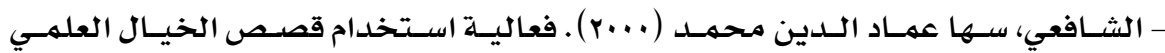

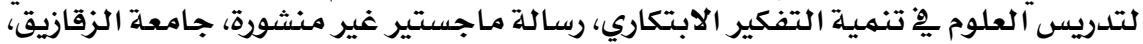
كلية التربية.

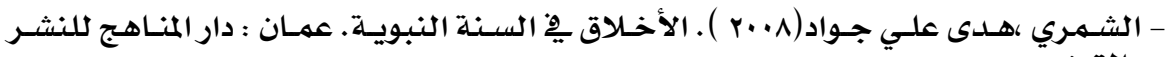
والتوزيـع.

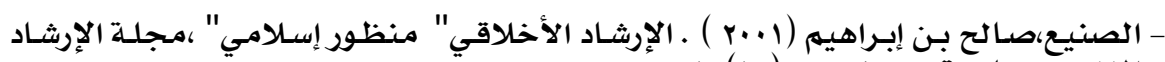

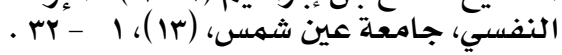

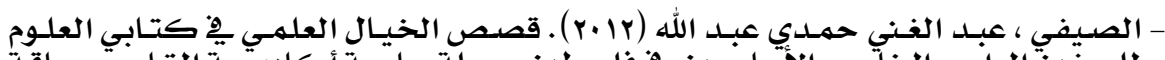

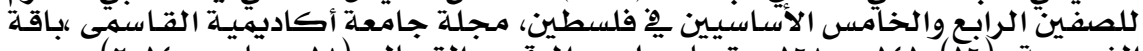

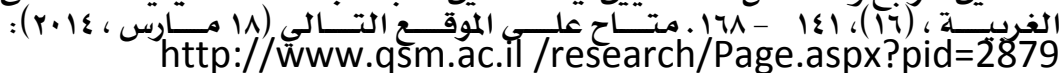

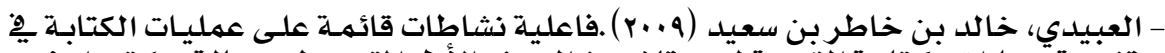

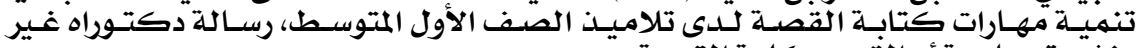

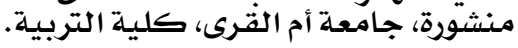

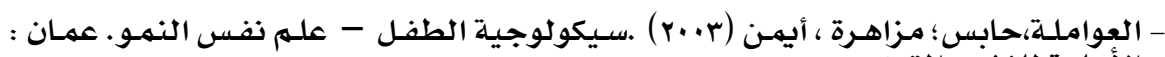

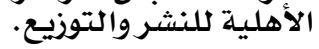

\section{YVI}




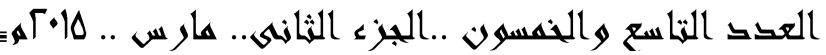

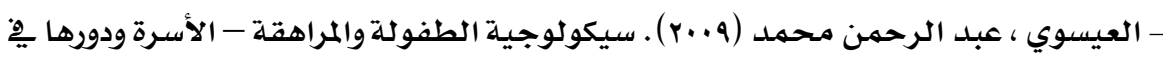

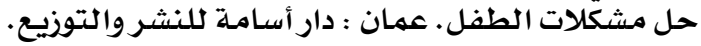

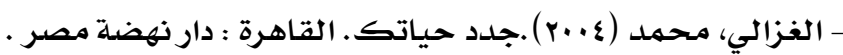

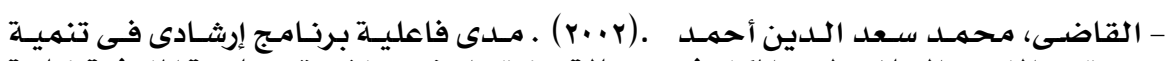

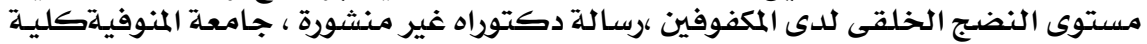

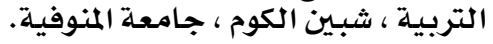

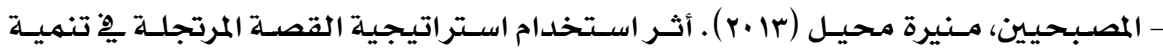

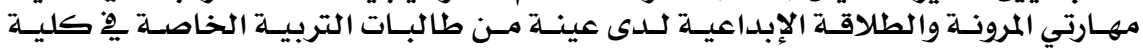

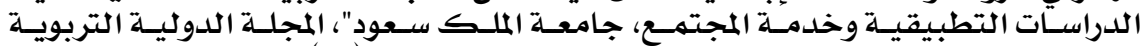

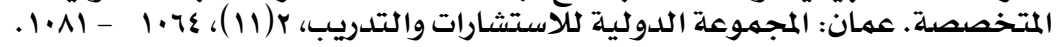

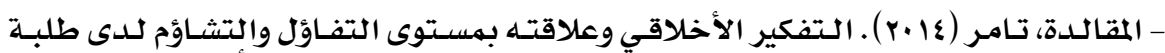

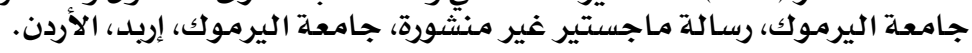

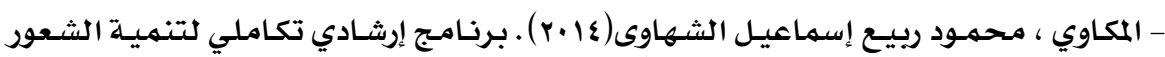

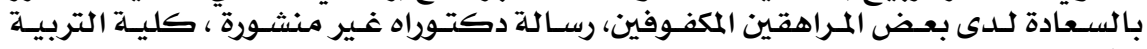

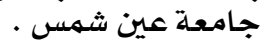

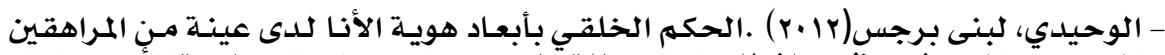

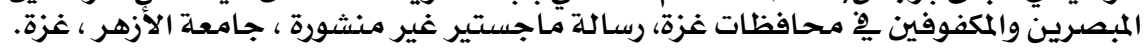

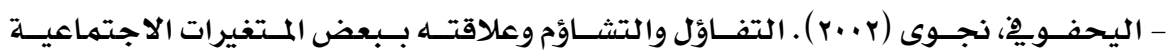

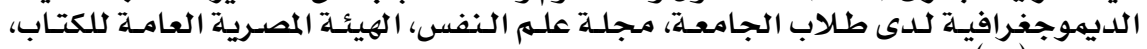

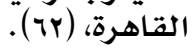

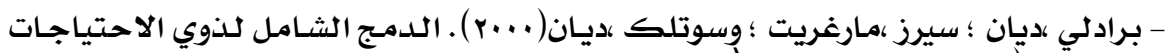

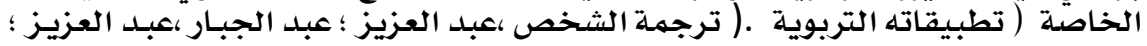

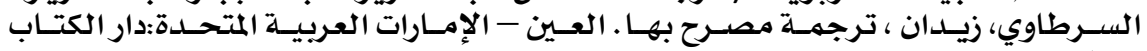
الجامعي. الجماوي،

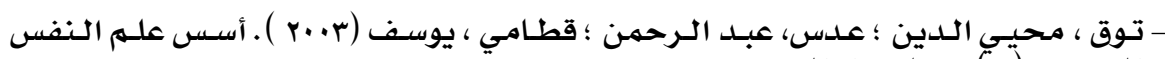

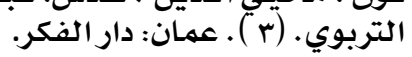

- جابر ، عبد الحميد جابر (19VVV) . مقياس القيهم الفارق. القاهرة: دار النهضة العربية.

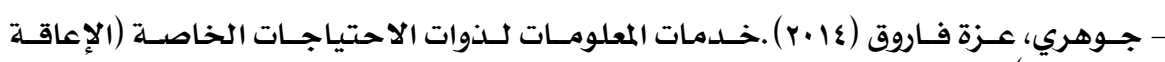

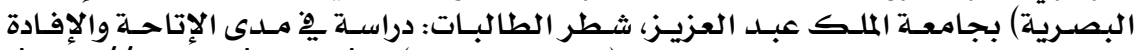

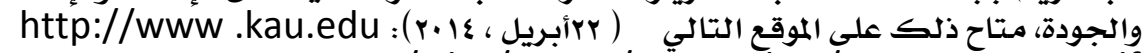
.sa/Files/12510/Researches/63382_34398.pdf

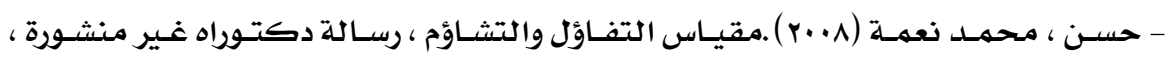

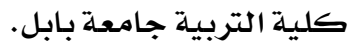

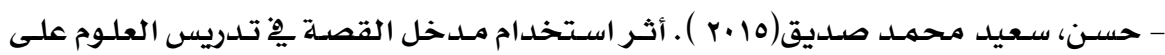

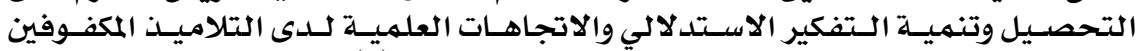

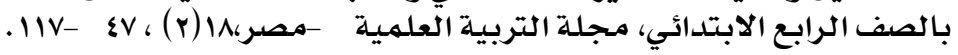

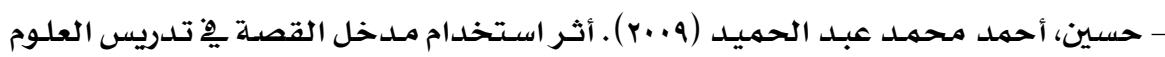

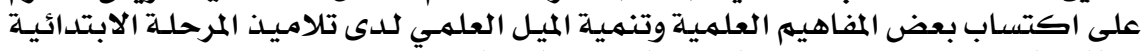

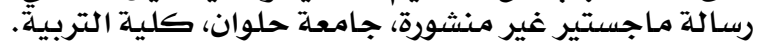

\section{YVY}


العكد التزاسع والخمسول ..الجزء الثخانىى.. هارس ..

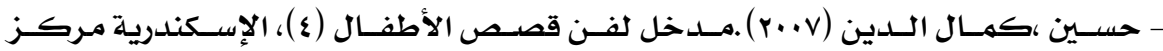
الإسكندرية للكتاب.

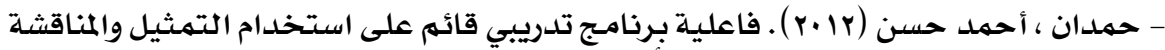

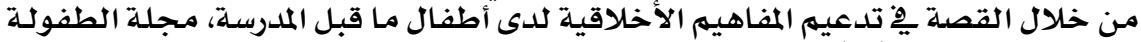

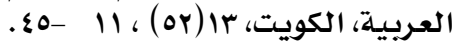

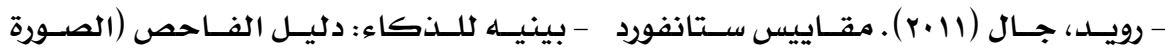

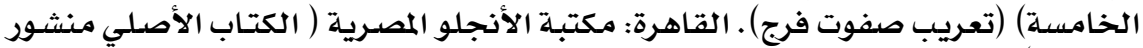
في r..ror)

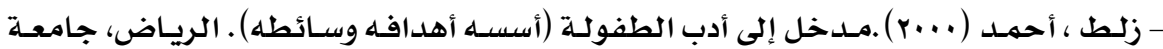

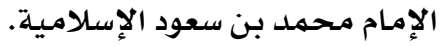

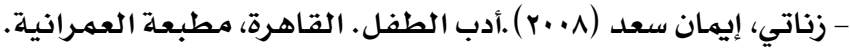

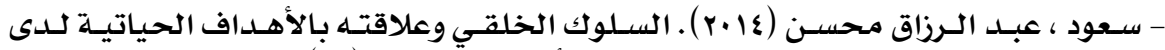

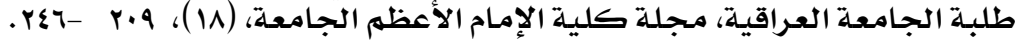

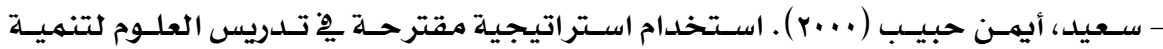

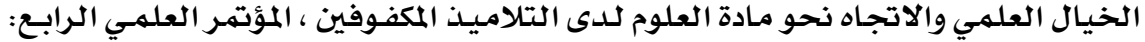

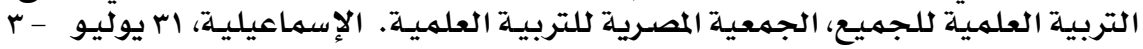

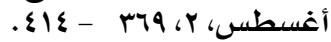

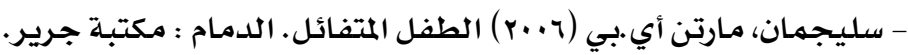

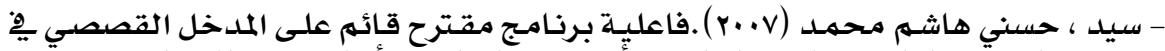

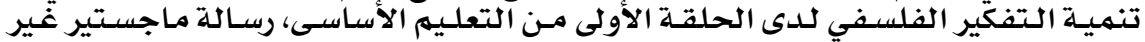
منشورة، جامعة حلوان، كلية الفية التربية.

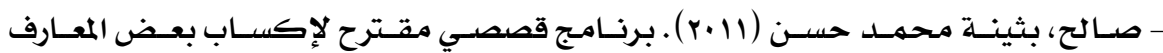

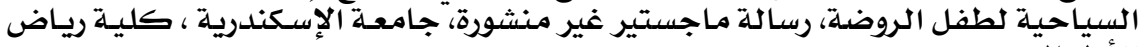

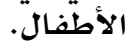

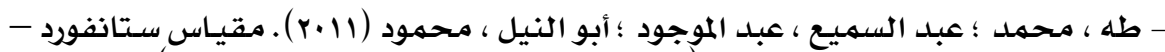

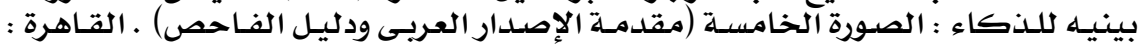

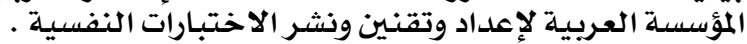

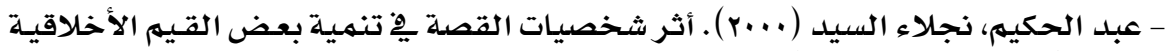

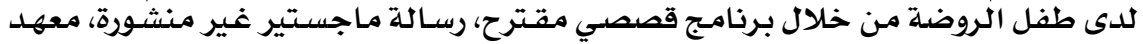
الدراسات التربوية، جامعة القاهرة، كن برنج

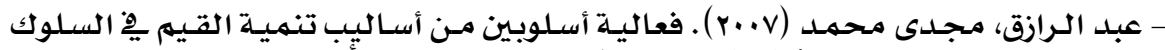

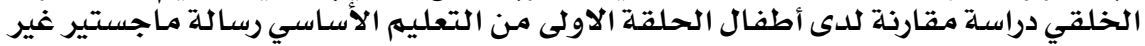

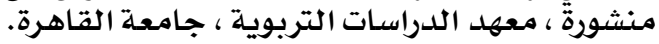

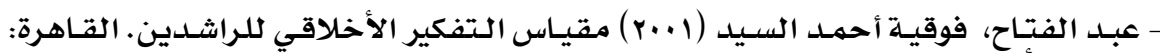

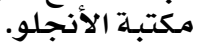

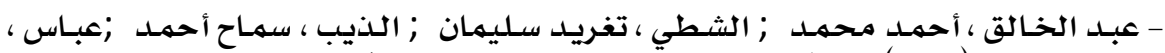

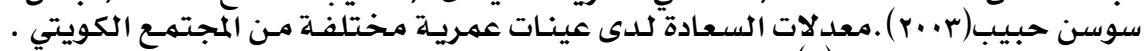

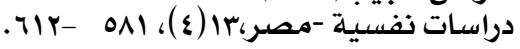

\section{YVY}




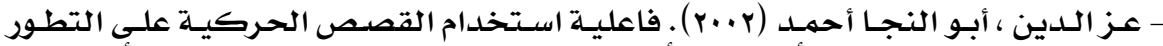

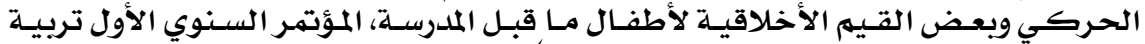

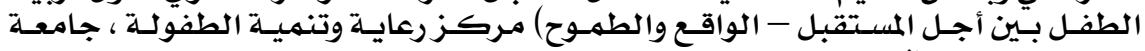

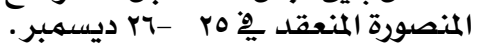

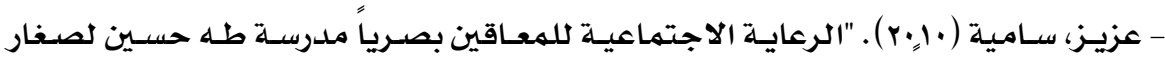

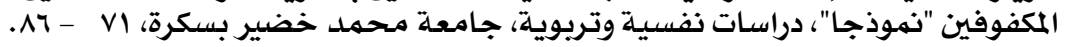

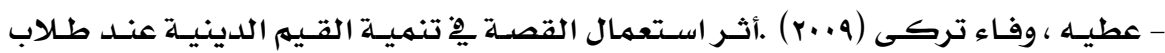

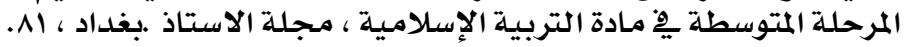

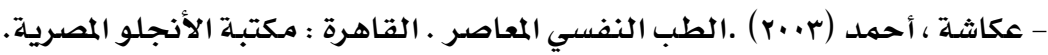

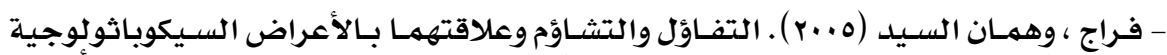

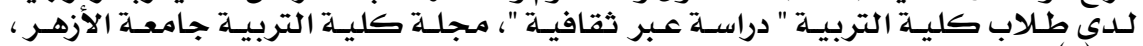
. ¿

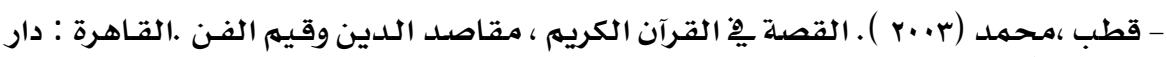

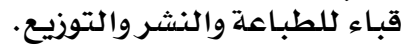

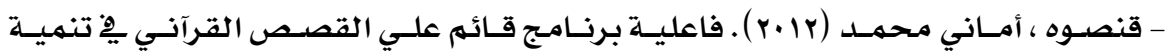

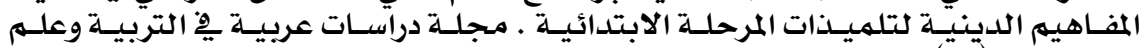

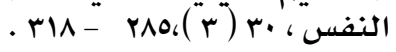

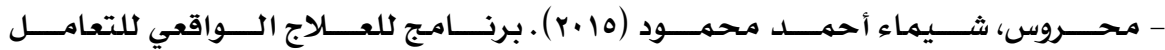

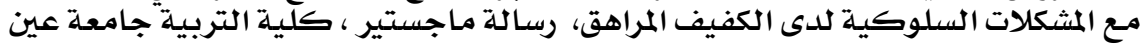
شمسع.

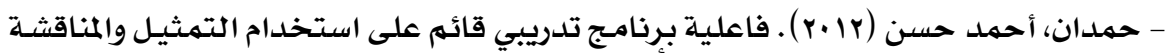

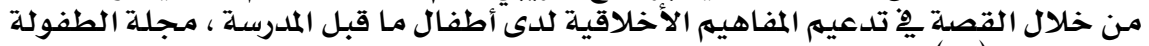

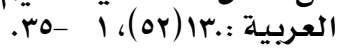

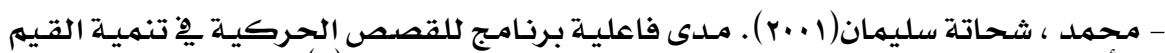

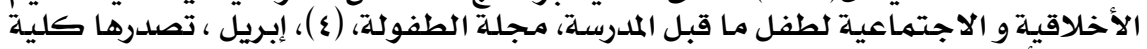
رياض الآطفال جامعة الآتهاعة القاهرة.

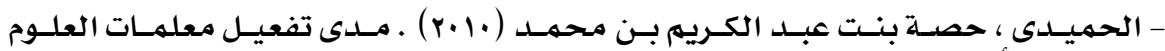

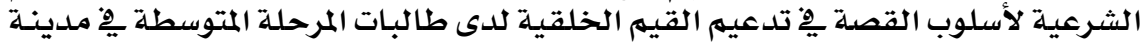

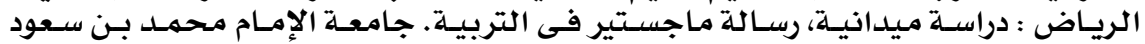

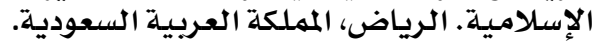

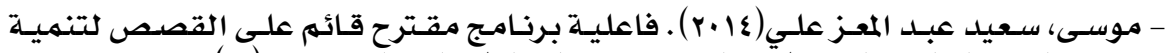

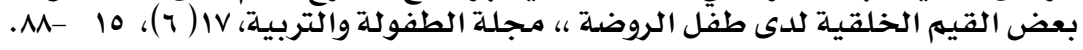

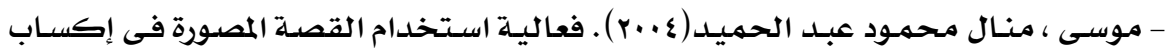

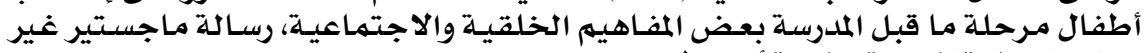

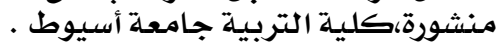

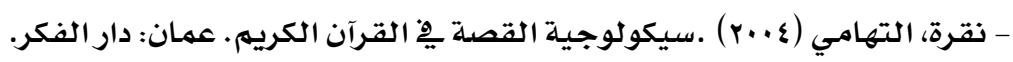

- Al- Somadi, M. (2012). The effect of a story -based programme on developing moral values at the kindergarten stage. Interdisciplinary journal of contemporary research in business, 4(7), 559-534.

\section{YV\&}


العكد التخاسع والخمسول ..الجزء الثخانىى.. هارس ..

- Armbruster, D.; Pieper, L.; Klotsche, J. \& Hoyer, J. (2015). Predictions get tougher in older individuals: a longitudinal study of optimism, pessimism and depression. Social psychiatry and psychiatric epidemiology, 50(1), 153-163.

- Beckett, C. \& Maynard, A. (2013). Values and ethics in social work. 2nd Ed. London: SAGE.

- Ben-Zur, H. \& Debi, Z. (2005). Optimism, social comparisons, and coping with vision loss in Israel. Journal of Visual Impairment \& Blindness, 99(3), 151.

- Boier, K.(2004). What is values?, New York, Teacher collage press.

- Borba, M.(2001).Building Moral Intelligence, San Francisco. Jossey - Bass, Awiley Company.

- Bunch, W.(2005).Changing moral judgment in divinity students, Journal of Moral Education. 34, 363- 370.

- Carver,C.\& Scheier,A. (2003). Optimism In S . J.LopezandC. R. snyder (Eds), handbook of positive psychology assessment : a handbook of models and measures, Washington DC: American Psychological Association ,75- 89 .

- Cavendish, J.; Stopps, B. \& Ryan, C. (2006).Involving young children through stories as starting points, Primary Science Review, 92, 18-20.

- Eaude, T. (2008).Children's Spiritual, Moral, Social and Cultural Development. SAGE Publications Ltd: London.

- Egan, K. (2007).Imagination, past and present, In K. Egan, M. Stout, \& K. Takaya (Eds.), Teaching and Learning outside the Box. New York: Teachers College Press.

- Esteban, M.; Sidera, F.; Serrano, J.; Amadó, A. \& Rostan, C. (2010). Improving social understanding of preschool children: Evaluation of a training program. Electronic Journal of Research in Educational Psychology, 8(2), 841-860.

- Fernández-González, L.; González-Hernández, A.; Trianes-Torres, V. M. (2015). Relationships between Academic Stress, Social Support, Optimism-Pessimism and Self-Esteem in College Students. Electronic Journal of Research in Educational Psychology, 13(1), 111-130. 


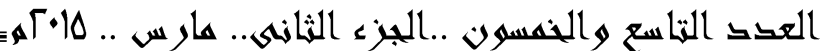

- Green, M. (2004). Storytelling in teaching. Association for Psychological Sciences Observer, 17(4), 37-39.

- Grimes, S. (2015). An evaluation of aggression replacement training: the impact of a multi-component, CBT-based intervention on the problem behaviors, pro-social skills and moral development of pupils in English secondary schools. (Unpublished dissertation).The University of Nottingham, United Kingdom.

- Haydon, G. (2007). Values for educational leadership. SAGE Publications Ltd: Thousand Oaks, California.

- Hirsch, K. \& Conner ,R. (2006). Dispositional and explanatory style optimism as potential Moderators of the relationship between hopelessness and suicidal ideation suicide and life- threatening behavior, 36(6 ),661- 669 .

- Hsiu-Chih, S. (2008). The value of English picture story books. ELT journal, 62(1), 47-55.

- Hupp, G.(2003).Cognitive differences between congenitally and adventitiously blind individuals", Ph. D. Thesis, North Texas, University of North Texas.

- Kabady, A. \& Aldag, K. (2010). Comparison of the Moral Development of the Students Attending Different Primary Schools from Different Variables, International Journal of Human Science, 7 (1), 878-898.

- Krettenauer ,T.\& Eichler, D.(2006).Adolescents 'self-attributed moral emotions following a moral transgression: Relations with delinquency, confidence in moral judgment and age, British Journal of Developmental Psychology ,24, 489-506.

- Kvande, M. N.; Klöckner, C. A. ; Moksnes, U. K.; Espnes, G. A. (2015). Do Optimism and Pessimism Mediate the Relationship Between Religious Coping and Existential Well-Being? Examining Mechanisms in a Norwegian Population Sample. The International Journal for the Psychology of Religion, 25(2), 130.

- Lakeesha, N., Woods, H., Robert J. \& Jagers, D. (2003). Are cultural values predictors of moral reasoning in African American adolescents?. Journal of Black Psychology, 29, 102-118.

- Lee, K.; Talwar, V.; McCarthy, A.; Ross, I.; Evans, A. \& Arruda, C. (2014). Can classic moral stories promote honesty in children?. Psychological science, 25(8), 1630-1636.

\section{YVY}


- Lönnqvist „J.; Walkowitz, G.;Wichardt, P.; Lindeman, M.\&Verkasalo ,M.(2009).The moderating effect of conformism values on the relations between other personal values, Social Norms, Moral Obligation, and Single Altruistic Behaviours, Br J Soc Psychol. Sep,48(3),525-46.

- Ma, K.; Liao, I.; Frazier, J.; Hauser, H., \& Kostis, H.(2014).Scientific storytelling using visualization, 1-8. Retrieved February 21, from http://vis.cs.ucdavis.edu/papers/Scientific_Storytelling_CGA.

- Mims, P. ; Browder, D. ; Baker, J. ; Lee, A. \& Spooner, F. (2009). Increasing comprehension of students with significant intellectual disabilities and visual impairments during shared stories. Education and Training in Developmental Disabilities, 409-420.

- Norman, R.( 2008). The Moral Philosophers, Oxford University Press, : Moral and Political Philosophy, Palgrave, Macmillan, New York, 73-171.

- Pramiling , N.; Norlander , T.\& Archer , T.(2001). Moral Expression in 6- to 7-year-old Children's Stories in Sweden, Hungary and China: A Phenomenological Study, Childhood August 8, 361-382. doi:10.1177/0907568201008003004

- Pinquart, M. \& Pfeiffer, J. (2014). Worry in adolescents with visual impairment. British Journal of Visual Impairment, 32(2), 94-107.

- Rusko,M.;Trnka,M.;Darjaa,S.\& Ritomský,M.(2014). Dramatic Piece Reader and It's Evaluation by the Blind and Sighted Assessors, The series Lecture Notes in Computer Science, 8773 ,184-191.

- Seligman, M. (2006). Learned optimism: How to change your mind and your life. New York: Vintage Books.

- Suric, D. (2014). Using Multimedia Social Stories to Enhance Prosocial Behavior of At-Risk Preschoolers.Master Dissertation. University of South Florida, United States.

- Tadić, V.; Pring, L. \& Dale, N. (2013). Story discourse and use of mental state language between mothers and school aged children with and without visual impairment. International Journal of Language \& Communication Disorders, 48(6), 679-688.

- William,I. (2003). Individual variations in responses to a hypothetical moral dilemma.- higher test, Journal of Moral Education, 31, 247-270. 
العكد التزاسع والخهسول ..الجزء اللثانهى.. هار س ..

- Yulianty, Y. \& Premadi, P. (2009).Teaching science using storytelling method", Proceedings of the Conference of the Indonesia: A Astronomy and Astrophysics, Bandung, 2931October, ,3-34.

- Zazkis, R. \& Liljedahl, P. (2009). Teaching mathematics storytelling, A W Rotterdam, Sense Publishers.

溇溇溇溇垱 